UNIVERSIDADE DE SÃO PAULO

INSTITUTO DE ENERGIA E AMBIENTE

PROGRAMA DE PÓS-GRADUAÇÃO EM CIÊNCIA AMBIENTAL

JOAQUIM ALVES DA SILVA JÚNIOR

DESAFIOS E PERSPECTIVAS DO PROGRAMA

TERRITÓRIOS DA CIDADANIA: O CASO DO TERRITÓRIO

DA CIDADANIA VALE DO RIBEIRA-SÃO PAULO, SP 
JOAQUIM ALVES DA SILVA JÚNIOR

\section{DESAFIOS E PERSPECTIVAS DO PROGRAMA TERRITÓRIOS DA CIDADANIA: O CASO DO TERRITÓRIO DA CIDADANIA VALE DO RIBEIRA- SÃO PAULO, SP.}

Dissertação apresentada ao Programa de PósGraduação em Ciência Ambiental do Instituto de Energia e Ambiente da Universidade de São Paulo para obtenção do título de Mestre em Ciência Ambiental.

Orientador: Prof ${ }^{0}$ Dr. Luiz Carlos Beduschi Filho.

\section{Versão Corrigida}

(versão original disponível na Biblioteca da Unidade que aloja o Programa e na Biblioteca Digital de Teses e Dissertações da USP) 
AUTORIZO A REPRODUÇÃO E DIVULGAÇÃO TOTAL OU PARCIAL DESTE TRABALHO, POR QUALQUER MEIO CONVENCIONAL OU ELETRÔNICO, PARA FINS DE ESTUDO E PESQUISA, DESDE QUE CITADA A FONTE.

Silva Junior, Joaquim Alves.

Desafios e perspectivas do Programa Territórios da Cidadania: o caso do Território da Cidadania Vale do Ribeira./ Joaquim Alves Silva Junior; orientador : Luiz Carlos Beduschi Filho.- São Paulo, 2015. 181f.: il.; $30 \mathrm{~cm}$.

Dissertação (Mestrado - Programa de Pós-Graduação em Ciência Ambiental ) - Universidade de São Paulo.

1. Planejamento territorial -Vale do Ribeira. 2. Políticas públicas. 3. Sustentabilidade I. Título. 


\section{FICHA DE APROVAÇÃO}

Joaquim Alves da Silva Júnior

DESAFIOS E PERSPECTIVAS DO PROGRAMA TERRITÓRIOS DA CIDADANIA: O CASO DO TERRITÓRIO DA CIDADANIA VALE DO RIBEIRA- SÃO PAULO, SP.

Dissertação apresentada ao Programa de PósGraduação em Ciência Ambiental do Instituto de Energia e Ambiente da Universidade de São Paulo para a obtenção do título de Mestre em Ciência Ambiental.

Aprovado em

Banca examinadora

Prof. Dr.

Instituição Assinatura

Prof. Dr.

Instituição Assinatura

Prof. Dr.

Instituição Assinatura 
DEDICATÓRIA

Às trabalhadoras e aos trabalhadores que financiaram esta pesquisa científica. 


\section{AGRADECIMENTOS}

A pesquisa é realizada em sua maior parte no âmbito da "conversa" solitária com os autores de livros, artigos científicos e relatórios governamentais. Mas este trabalho também é fruto do entrelaçamento de ideias e sonhos que foram se juntando e também se desagregando, porque a vida é feita da construção e da desconstrução, da morte e do renascimento de uma nova pessoa todos os dias. Este relatório está longe de representar todo o aprendizado tomado por este que vos fala durante a realização deste estudo, pois a realidade vivenciada foi muito além do que é permitido ou possível exprimir na escrita. Isto só foi possível por causa da intensa interação, diálogo e aprendizado ocorrido durante a elaboração deste estudo, o que me faz sentir como o maior privilegiado deste processo. Como afirma o Mestre Paulo Freire "O diálogo é o encontro amoroso dos homens (e mulheres) que, mediatizados pelo mundo, o 'pronunciam', isso é, o transformam, e, transformando-o, o humanizam para a humanização de todos".

Agradeço, em primeiro lugar, à Marinalva de Jesus Santos. Esta mulher me ensinou e me ensina na prática o significado da palavra determinação.

Agradeço ao professor Beduschi pela confiança e ao intenso aprendizado pelo qual eu fui submetido nestes oito anos de relação. Muito obrigado por todas as portas e oportunidades que você me abriu durante a minha viagem em busca do conhecimento.

Agradeço a professora Cristina Adams por me dar a oportunidade de imersão no Vale do Ribeira. Agradeço ao grupo de pesquisa de Ecologia Histórica do Vale do Ribeira por ela coordenado, principalmente ao Jordano e a Daniela. As nossas discussões foram extremamente enriquecedoras e tiveram um papel fundamental para a elaboração deste trabalho. Participar do grupo me permitiu conhecer diversos intelectuais das mais variadas áreas do conhecimento. Um grupo desta importância e profundidade permite que cheguemos cada vez mais próximos da aplicação da interdisciplinaridade na pesquisa científica.

Um agradecimento especial ao Alexandre Antunes Ribeiro Filho, também componente do grupo de pesquisa em Ecologia Humana e um grande companheiro. Foi a sua iluminada presença na minha vida que impediu a minha desistência do mestrado em momentos de maiores dificuldades.

Agradeço ao professor Eduardo Caldas pelo apoio direcionado à compreensão do mundo das políticas públicas.

Agradeço aos professores, alunos e funcionários do Instituto de Energia e Ambiente, Juliana, André, Mariana, Fernanda, Laize, Alice, Felipe, Flávia, pelas várias festas e conversas. 
Clarinha, Henrique! Muito obrigado! Vocês trazem a humanidade de volta pro mundo!

Agradeço por ter reencontrado o Daniel e o Sérgio, amigos que foram fundamentais na minha iniciação na política universitária.

Agradeço ao privilégio de ter participado do Projeto Criando Terra no IEE. Este projeto fez eu me apaixonar pela extensão universitária. E foi o momento de criar ações e reflexões de extrema qualidade e profundidade sobre os reais direcionamentos da universidade pública como agente promotora das transformações sociais.

Por isso, também agradeço a oportunidade de participar de duas gestões à frente a Associação de Pós-Graduação Helenira "Preta" Rezende, em especial ao PH e ao Marcelo. Foi um momento de muita reflexão sobre as reais funções dos movimentos estudantis.

Agradeço à Larissa, a Patrícia e a Melina, as meninas do refúgio que me refugiaram em diversos momentos.

Agradeço aos gestores públicos do Estado e da União, aos agricultores familiares, às comunidades quilombolas, às ONGs, aos técnicos municipais, aos representantes de associações e cooperativas e aos moradores locais, por me proporcionar uma experiência única de vida.

Um agradecimento especial ao Roberto Resende, que me indicou grande parte dos atores sociais do Vale com quem eu conversei.

E por fim, agradeço à Universidade de São Paulo.

Esta dissertação foi financiada pelo Programa de Demanda Social, da Coordenação de Aperfeiçoamento de Pessoal de Nível Superior - CAPES.

Eu me responsabilizo por todos os erros e equívocos descritos nas paginas a seguir. 
EPÍGRAFE

Arranque a colheita das mandíbulas do dragão (Yuan-Tsung Chen - Memórias de uma Revolucionária) 


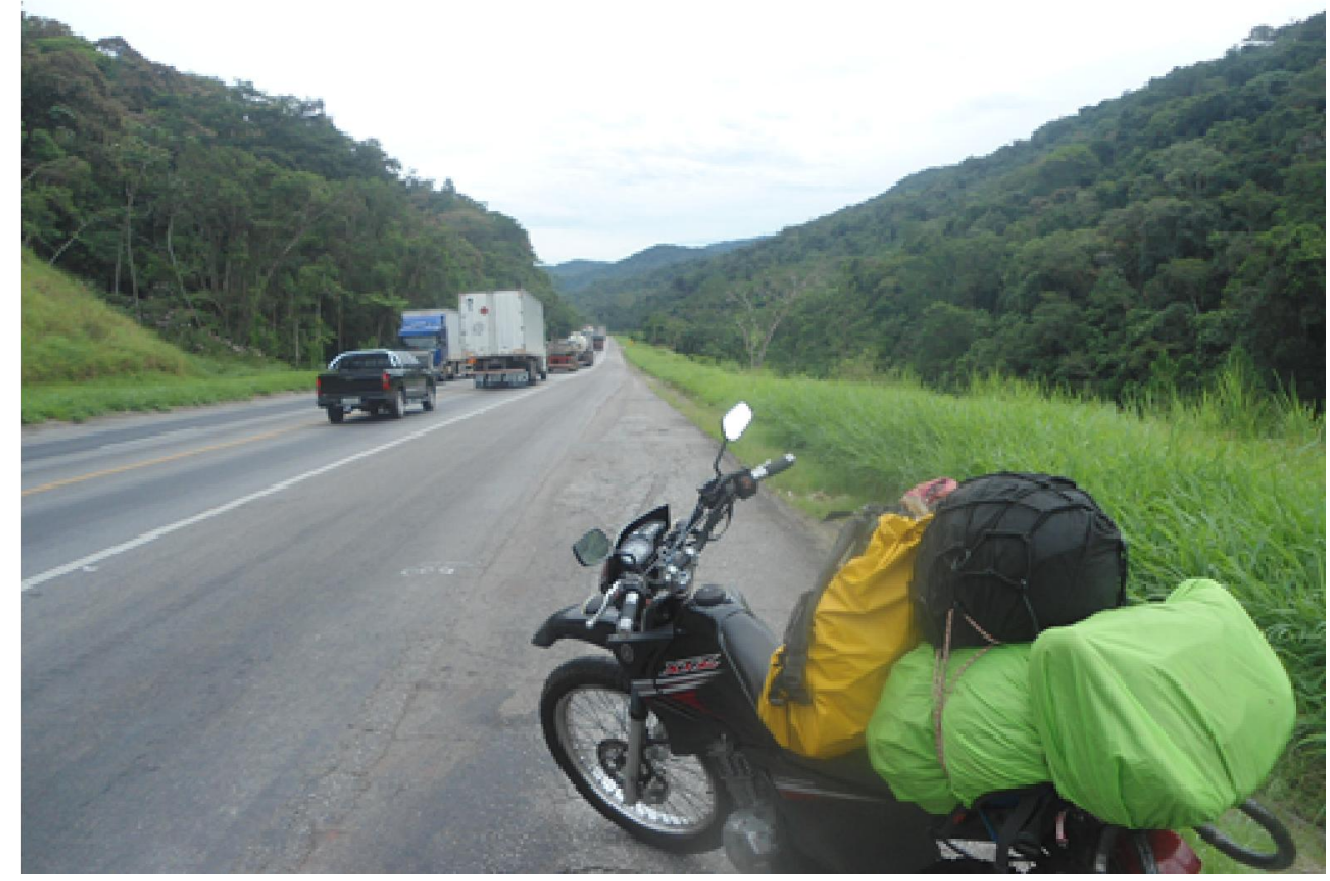




\section{RESUMO}

SILVA JÚNIOR, Joaquim Alves. Desafios e perspectivas do Programa Territórios da Cidadania: O caso do Território da Cidadania Vale do Ribeira - São Paulo, SP. 2015. 189 f. Dissertação (Mestrado em Ciência Ambiental) Programa de Pós-Graduação em Ciência Ambiental - Instituto de Energia e Ambiente da Universidade de São Paulo, São Paulo, 2015.

O Programa Territórios da Cidadania foi implementado em 2008, com a proposta de dar continuidade à consolidação da abordagem territorial do desenvolvimento rural iniciada pelo Programa Nacional de Desenvolvimento Sustentável dos Territórios Rurais, lançado em 2003. O Programa Territórios da Cidadania surgiu como uma resposta às críticas em torno do viés setorial e estritamente focado na agricultura familiar promovido pelos Territórios Rurais. Assim, o Programa Territórios da Cidadania teria o importante objetivo de universalizar as políticas sociais em torno de um planejamento territorial voltado a promoção do Desenvolvimento Territorial Rural Sustentável. Os objetivos em questão seriam concretizados através da integração entre as ações ministeriais, e a coordenação da política nas três esferas de governo. Tal processo valorizaria os pressupostos da multidimensionalidade, das múltiplas escalas de poder e seria calcado na ampla participação popular. Assim, temos como objeto de estudo o Território da Cidadania Vale do Ribeira - SP. O território em questão possui uma diversidade sociocultural única, marcada pelas diversas investidas de ocupação territorial tanto por migrantes brasileiros como por estrangeiros. Aliado a este fenômeno, as características geográficas, e as condicionantes políticas regionais, foram determinantes na manutenção da biodiversidade da Mata Attântica na região, que hoje forma o principal corredor deste bioma no Brasil. O Território da Cidadania Vale do Ribeira é marcado por diversas tentativas de execução de planos e ações tanto por parte do poder público como por iniciativas das organizações sociais. Entretanto, as propostas foram executadas de forma dispersa e intermitente, não se traduzindo na socialização das externalidades positivas propostas pelos planos e ações e mantendo o quadro regular de indicadores econômicos e sociais. Na virada do milênio, as dinâmicas socioeconômicas do Território do Vale do Ribeira apontam para uma variação das atividades produtivas, decaindo a importância do setor agrícola e o aumento quantitativo em torno setor de serviços, além de uma relativa melhora dos indicadores sociais e econômicos, dinâmicas estas motivadas pelo aumento das inversões públicas na região que foram intensificadas no início dos anos 2000. A partir deste contexto, os objetivos desta dissertação passaram pela compreensão dos desafios e perspectivas que emergiram com a implementação dos programas territoriais no Território da Cidadania Vale do Ribeira, em especial o Programa Territórios da Cidadania. Os resultados desta dissertação mostram que o programa em evidência não efetivou os objetivos propostos na sua formulação. Ao contrário, a implementação do programa foi marcada pela desmobilização generalizada da participação popular e do poder público, refletindo no retrocesso da perspectiva territorial como uma categoria de política pública orientada ao desenvolvimento do meio rural. O reflexo deste processo identifica que as poucas inovações obtidas com a implementação do Programa Nacional de Desenvolvimento Sustentável dos Territórios Rurais foram perdidas, havendo assim um retrocesso no uso do discurso da abordagem territorial. Este resultado tem como fatores determinantes as relações assimétricas de poder, bem como o contexto do poder público local marcado pela resistência a mudanças na forma de planejar o uso dos recursos públicos e pelos conflitos político-partidários reproduzidos por gestores públicos e lideranças locais.

Palavras-chave: Desenvolvimento Territorial Rural, Abordagem Territorial, Programa Nacional de Desenvolvimento Sustentável dos Territórios Rurais, Programa Territórios da Cidadania, Território da Cidadania Vale do Ribeira, de Políticas Públicas, Sustentabilidade. 
SILVA JÚNIOR, Joaquim Alves. Challenges and perspectives of Citizenship Territories Program: The case of Ribeira Valley Citizenship Territory - São Paulo, SP. 2015. 189 f. Master's Dissertation - Graduate Program of Environmental, Universidade de São Paulo, São Paulo, 2015.

\begin{abstract}
The Citizenship Territories Program was implemented in 2008, with the proposal to extent the consolidation of territorial approach to rural development initiated by Rural Territories for Sustainable Development National Program released in 2003. Furthermore, the The Citizenship Territories Program emerge as a response to criticism about sector bias and strictly focused on Family farming. This, the Citizenship Territories Program would have de importance role of universal social policies around a territorial planning aimed at promoting Territorial Rural Sustainable Development. The objectives would be achievement through the integration between ministerial actions and policy coordination in the three governmental spheres. This process would value the assumptions of multidimensionality, the multiple scales of power and would be underpinned by the broad popular participation. Thus, we have as object of study's object the Ribeira Valley Territory Citizenship, located in southeastern portion of State of São Paulo. The territory has a unique socio-cultural diversity, marked by several territorial occupation invested by both Brazilian migrants as by foreigners. The geographic, regional and political constraints, were instrumental maintaining the biodiversity of the Atlantic Florest in the region, that now forms the main ecological corridor of this biome in Brazil. The Ribeira Valley Territory Citizenship is marked by several attempts to implement plans e actions by both the government as per initiatives of social organizations. However, the proposals have been implemented in a dispersed and intermittent, not translating in the socialization of positive externalities proposed by plans and actions, and keeping the regular framework of economic and social indicators. From the turn of the millennium, socioeconomic dynamics Ribeira Valley Territory show a variation of productive activities, with decreasing the importance of the agricultural and the quantitative increase around service sector, and a relative improvement of social and economic indicators, dynamics driven by increased public investments in the region, intensified in the early 2000 . From this context, the objectives of this dissertation passed through the understanding of the challenges and perspectives the emerged with the implementation of regional programs in the Ribeira Valley Territory Citizenship, especially the Citizenship Territories Program. The results show the program not effected the proposed objectives in its formulation. On de contrary, the implementation of the program was marked by widespread demobilization of popular participation and government, reflecting the retreat of the territorial perspective as a public policy category oriented to the development of rural areas. The effects process identifies the few innovations achieved with the implementation of the Territories for Sustainable Development National Program were lost, so there is a regression in the use of the discourse of territorial approach. This result has as determinants the asymmetrical power relation as well as the local government context marked by resistance to changes in the way planning the use of public resources and the party-political conflicts played by public officials and local leaders.
\end{abstract}

Keywords: Rural Territorial Development, Territorial Approach, Rural Territories for Sustainable Development National Program, Citizenship Territories Program, Ribeira Valley Citizenship Territory, Public Policy, Sustainability 


\section{LISTA DE TABELAS}

Tabela 4.1 - Abrangência nacional do Programa Territórios da Cidadania

Tabela 4.2 - Evolução da Concentração da Propriedade da Terra no Brasil Medida pelos imóveis 2003/2010 71

Tabela 5.1 - Unidades de Conservação do Território Vale do Ribeira 77

Tabela 5.2 - População Total, Rural e Urbana (valores absolutos e relativos), Área Densidade

Demográfica e Variação Populacional dos Municípios do Vale do Ribeira 81

Tabela 5.3 - índice de Desenvolvimento Humano Municipal do Território Vale do Ribeira 83

Tabela 5.4 - Taxa de Analfabetismo e taxa da população com ensino médio (\%) 84

Tabela 5.5 - Matrículas efetuadas na graduação presencial (2012) 85

Tabela 5.6 - Variação dos empregos gerados por setor da economia no Vale do Ribeira entre

2002 e $2012 \quad 87$

Tabela 5.7 - Participação dos setores em relação ao total do valor adicionado (\%) 88

Tabela 5.8 - Entidades do Território Vale do Ribeira participantes da modalidade CPR

Doação/PAA entre 2010 e 2014

Tabela 5.9 - Produto Interno Bruto das Regiões Administrativas e Regiões Metropolitanas 92

Tabela 5.10 - Quadro geral do Número de Delegados eleitos para participar da Conferência

Territorial, de acordo com a qualificação do delegado e o segmento de representação 121

Tabela 5.11 - Projetos socioambientais aprovados entre 2006 e 2007 127-128

Tabela 5.12 - Comissão Executiva CONSAD para o biênio 2009/2011 133

Tabela 5.13 - Núcleo Diretivo do CONSAD para o biênio 2011 - 2013

Tabela 5.14 - Metas apontadas para a gestão territorial de 2014

Tabela 5.15 - Prefeitos eleitos no Território do Vale do Ribeira 152 


\section{LISTA D E FIGURAS}

Figura 2.1 - Modelo de múltiplos fluxos da abordagem territorial.......................................43

Figura 3.1 - Modelo dos Ciclos da Política pública..............................................................47

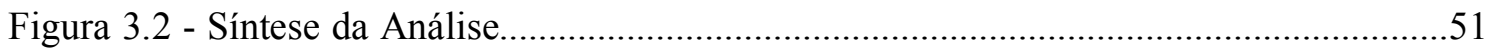

Figura 4.1 - O Ciclo de gestão do Programa Territórios da Cidadania....................................61

Figura 5.1 - Bacia Hidrográfica do Rio Ribeira de Iguape..................................................73

Figura 5.2 - Subdivisão geomorfológica da porção paulista do Vale do Ribeira.....................75

Figura 5.3 - Mapa das Unidades de Conservação No Vale do Ribeira....................................78

Figura 5.4 - Mapa do Território Vale do Ribeira, São Paulo, SP............................................80

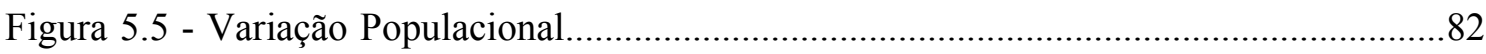

Figura 5.6 - Assoreamento do Mar Pequeno, Iguape......................................................98

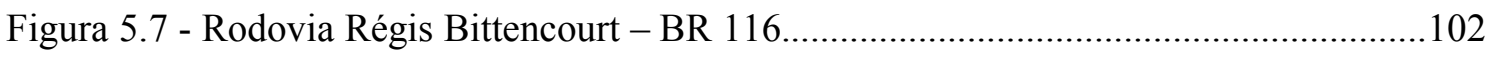

Figura 5.8 - Estrutura organzacional do CONSAD........................................................... 115

Figura 5.9 - Mapa do Território Vale do Ribeira São Paulo e Paraná......................................117

Figura 5.10 - Mapa da Alteração da divisão regional no âmbito do CONSAD em

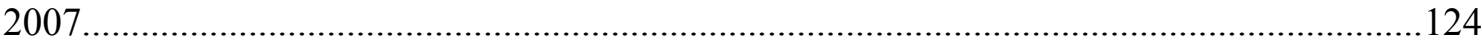

Figura 5.11 - Configuração Territorial da Mesorregião do Ribeira/Guaraqueçaba.................125

Figura 5.12 - Configuração da Bacia do Rio Ribeira de Iguape. (Figura Ilustrativa).............126

Figura 5.13 - Municípios participantes da Rede SANS (2012)..........................................137 


\section{LISTA DE FOTOS}

Foto 5.1 - Município de Eldorado, as margens do Rio Ribeira de Iguape 74

Foto 5.2 - Pousada Rural Cristina Ruivo, Eldorado $\quad 74$

Foto 5.3 - Caverna do Diabo, Eldorado $\quad 74$

Foto 5.4 - Balsa Cananéia - Ilha Comprida $\quad 74$

Foto 5.5 - Cachoeira de Meu Deus, Quilombo Sapatu, Eldorado 76 


\section{LISTA DE SIGLAS}

CATI - Coordenadoria de Assistência Técnica Integral

CATIVAR - Cooperativa de Assessoria Técnica Integral do Vale do Ribeira

CEADES - Instituto de Estudos e Assessoria ao Desenvolvimento

CETESB - Companhia de Tecnologia de Saneamento Ambiental

CIAT - Comissão de Implantação de Ações Territoriais

CONAB - Companhia Nacional de Abastecimento

CONDRAF - Conselho Nacional de Desenvolvimento Rural Sustentável

CONSAD - Associação Consórcio de Segurança Alimentar e Desenvolvimento Social do

Vale do Ribeira

CONSEA - Conselho Nacional de Segurança Alimentar

CONTAG - Confederação Nacional dos Trabalhadores na Agricultura

COOPAFARGA - Cooperativa dos Produtores Rurais e da Agricultura Familiar

COOPERAGUA - Cooperativa Agropecuária de Produtos Sustentáveis do Guapiruvu

CUT - Central Única dos Trabalhadores

ENREDE - Rede Nacional de Colegiados Territoriais

FAQUIVAR - Federação das Associações Quilombolas do Vale do Ribeira

FEAP - Fundo de Expansão do Agronegócio Paulista

FETRAF - Federação Nacional dos Trabalhadores e Trabalhadoras da Agricultura Familiar

FEPAF - Fundação de Estudos Agrícolas e Florestais

FF - Fundação Florestal

FNDE - Fundo Nacional do Desenvolvimento da Educação

FNMA - Fundo Nacional do Meio Ambiente

GEAF - Grupo Executivo de Ação Fundiária

ICMBio - Instituto Chico Mendes de Conservação da Biodiversidade

IDESC - Instituto para o Desenvolvimento Sustentável e Cidadania do Vale do Ribeira

INCRA - Instituto Nacional de Colonização e Reforma Agrária

ISA - Instituto Socioambiental

ITTAF - Instituto dos Trabalhadores na Transformação da Agricultura Familiar

ITESP - Fundação Instituto de Terras do Estado de São Paulo

ITR - Imposto Territorial Rural

MAPA - Ministério da Agricultura, Pecuária e Abastecimento

MASTERPLAN - Plano Diretor de Desenvolvimento Agrícola do Vale do Ribeira

MIN - Ministério da Integração Nacional

MDS - Ministério do Desenvolvimento Social e Combate a Fome

MMA - Ministério do Meio Ambiente

MME - Ministério de Minas e Energia

MDA - Ministério do Desenvolvimento Agrário

MST - Movimento dos Trabalhadores Sem -Terras

MTUR - Ministério do Turismo

MOAB - Movimento dos Ameaçados por Barragens

DLIS - Desenvolvimento Local Integrado e Sustentável

OSCIP - Organização da Sociedade Civil de Interesse Público 
PAA - Programa de Aquisição de Alimentos

PCA - Programa Comunidade Ativa

PCS - Programa Comunidade Solidária

PDTRS-VR - Plano de Desenvolvimento Territorial Sustentável do Vale do Ribeira

PNAE - Programa Nacional de Alimentação Escolar

PNDR Política Nacional de Desenvolvimento Regional

PNSAN - Plano Nacional de Segurança Alimentar

PROINF - Projetos d Infraestrutura e Serviços em Territórios Rurais

PROTER - Programa da Terra Assessoria, Pesquisa e Educação no Meio Rural

PROMESO - Programa de Sustentabilidade de Espaços Sub-Territoriais

PRONAF - Programa Nacional de Fortalecimento da Agricultura Familiar

PRONAT - Programa Nacional de Desenvolvimento Sustentável dos Territórios Rurais

PRONATEC - Programa Nacional de Acesso ao Ensino Técnico e Emprego

PTC - Programa Territórios da Cidadania

REAF - Reunião Especializada sobre Agricultura Familiar do Mercosul

REDE SANS - Rede de Defesa e Promoção da Alimentação Saudável

SAA - Secretaria da Agricultura e Abastecimento

SAN - Segurança Alimentar e Nutricional

SDT - Secretaria de Desenvolvimento Territorial

SEBRAE - Serviço e Apoio Técnico e Pequenas Empresas de São Paulo

Secretaria Especial da Promoção da Igualdade Racial

SESAN - Secretaria de Segurança Alimentar e Nutricional

SIM - Serviço de Inspeção Municipal

SISNAMA - Sistema Nacional do Meio Ambiente

SMA - Secretaria do Meio Ambiente

SNUC - Sistema Nacional de Unidades de Conservação

SINTRAVALE - Associação de Trabalhadores da Agricultura Familiar do Vale do Ribeira

STF - Supremo Tribunal Federal

STR - Sindicato dos Trabalhadores Rurais

SUASA - Sistema Unificado de Atenção a Sanidade Agropecuária

UNESP - Universidade Estadual Paulista "Júlio de Mesquita Filho" 


\section{SUMÁRIO}

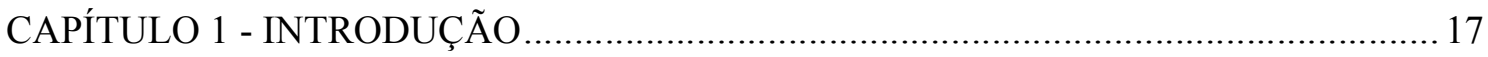

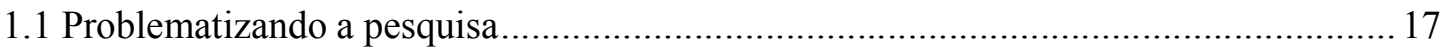

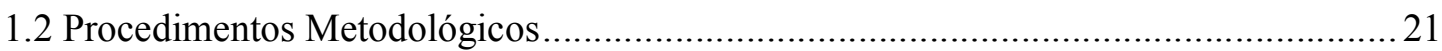

CAPÍTULO 2 - A ABORDAGEM TERRITORIAL DO DESENVOLVIMENTO RURAL. 24

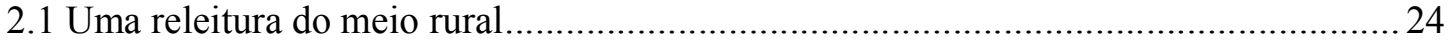

2.2 A agricultura familiar como uma nova categoria de análise .................................. 26

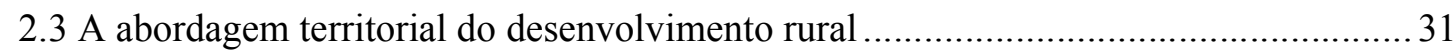

2.4 A formação da agenda das políticas publicas de Desenvolvimento Territorial............. 39

CAPÍTULO 3 - POLÍTICAS PÚBLICAS: BREVES CONSIDERAÇÕES ......................... 44

CAPÍTULO 4 - O MARCO TERRITORIAL NAS POLÍTICAS PÚBLICAS BRASILEIRAS

4.1 As primeiras experiências pelo Programa Nacional de Desenvolvimento Sustentável

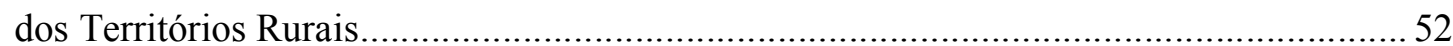

4.2 O Programa Territórios da Cidadania e a aposta na transversalidade da política pública

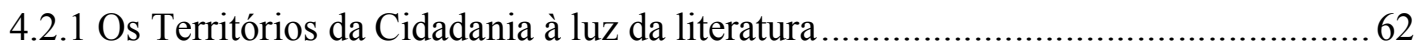

CAPÍTULO 5 - O TERRITÓRIO VALE DO RIBEIRA.............................................. 73

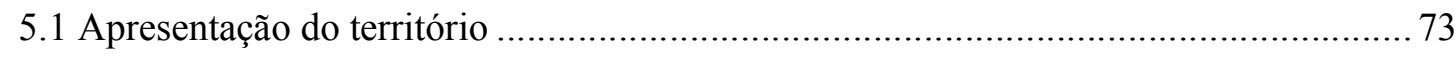

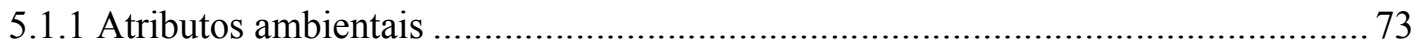

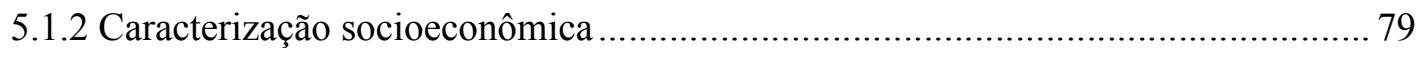

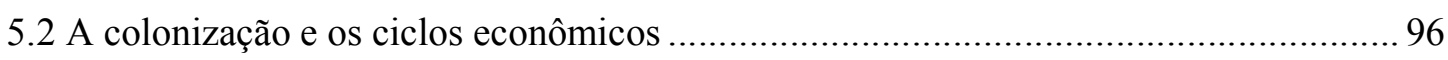

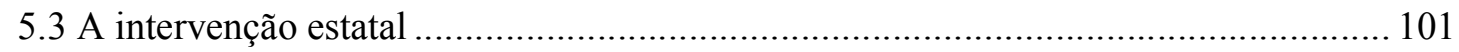

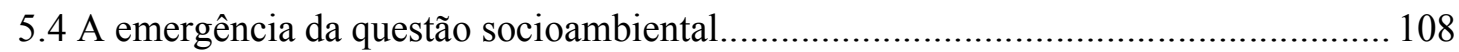

5.5 O PRONAT no Vale do Ribeira: formação do arranjo territorial................................ 114

5.5.1 Construindo o Projeto Vale do Ribeira Sustentável.......................................... 116

5.6 O Programa Territórios da Cidadania .................................................................. 131

5.6.1 A burocracia de rua do Programa Territórios da Cidadania Vale do Ribeira........ 138

5.7 Considerações sobre as possibilidades e limites dos programas territoriais no Vale do

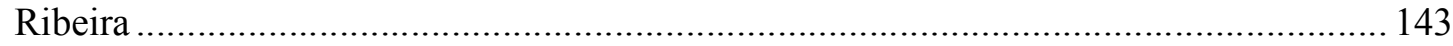

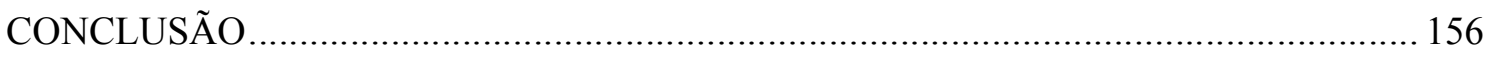

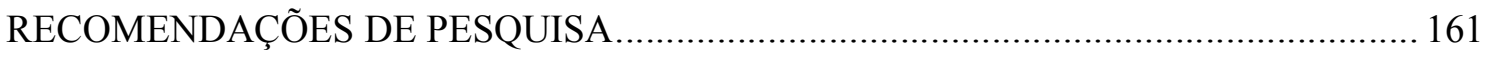

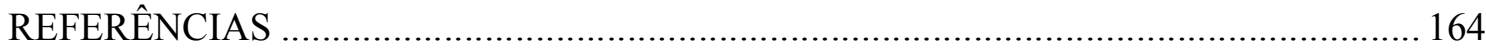

APÊNDICE A - Atividades realizadas no Território Vale do Ribeira................................ 179 


\section{CAPÍTULO 1 - INTRODUÇÃO}

\subsection{Problematizando a pesquisa}

O meio rural passou por diversas transformações ao longo das últimas décadas devido ao processo de releitura da ruralidade. A lente desta abordagem tinha o objetivo de ir além da visão estritamente produtivista e setorial do campo, que limitava a sua importância a um setor de produção agrícola. Esta visão acompanhava a chamada "revolução verde", cujo formato de desenvolvimento pautava-se pela produção de commodities agrícola concentradas em poucas propriedades com o discurso que o avanço tecnológico no setor agropecuário seria a única forma do Brasil não ficar atrasado em relação aos países desenvolvidos (BUAINAIN; ROMEIRO; GUANZIROLI, 2003).

Ao longo da década de 1990 os movimentos sociais do campo, consolidaram e difundiram a pauta de melhores condições de qualidade de vida no meio rural, com base na justificativa de apoio dos então pequenos produtores para a sua manutenção no campo. Esta reivindicação histórica dos movimentos tinha como objetivo principal evitar o êxodo rural e aumentar as chances de permanência dos agricultores no meio rural.

Por outro lado, os estudiosos da ruralidade acompanhavam com grande interesse as experiências internacionais que na época já se encontravam no estágio de implementação de políticas pública com um enfoque diferente do estritamente setorial. O sentido desta abordagem era reavaliar o significado de ruralidade, restrito a um setor produtivo e setorizado, sendo este o ponto de partida da reflexão com estudos que enfatizavam as relações e as dicotomias entre o urbano e o rural.

Estas experiências foram fundamentais para a elaboração de estudos voltados à compreensão das unidades de pequenos produtores nos países da América Latina, em especial o Brasil. Esses estudos consolidaram o termo agricultura familiar no vocabulário acadêmico. A noção de agricultura familiar, interpretada como a agricultura que se utiliza fundamentalmente da mão-de-obra familiar para a produção, alçou o tema para a agenda política e influenciou no sentido de promover políticas públicas específicas para esta faixa de população, que até então nunca havia sido motivo de debates para implementação de políticas (FAVARETO, 2006a).

A releitura do meio rural se apoia na abordagem da complexidade dos sistemas socioculturais e a sua relação com o meio natural, definida como abordagem territorial do desenvolvimento rural. Esta abordagem lança luz aos territórios, que segundo Abramovay 
(2000a) “... possui um tecido social, uma organização complexa feita por laços que vão muito além de seus atributos naturais; dos custos de transporte e de comunicação".

O crescente movimento social do campo que reivindicava melhores condições de vida e de trabalho (SCHNEIDER; MATTEI; CAZELLA, 2004), e as novas abordagens teóricometodológicas realizados sobre o meio rural, trouxeram à tona novos desafios e potencialidades do meio rural brasileiro. Adiciona-se a importância da noção de agricultura familiar como categoria de política pública e como bandeira em torno da melhoria de qualidade de vida e produtividade no campo. Tal contexto, em convergência com a mudança de governo no nível nacional, promoveu a alteração da agenda de governo em torno dos desafios ao desenvolvimento dos territórios. Se antes a agenda se concentrava na formulação e implementação de políticas voltadas a equilibrar as contas públicas numa economia num cenário de crise internacional, a década de 2000 formulou-se uma agenda política com forte caráter social. Esta agenda visava à formulação de políticas de combate a fome e ao desenvolvimento das regiões rurais mais deprimidas.

Com o intuito de fomentar a abordagem territorial do desenvolvimento rural como um enfoque privilegiado de políticas públicas direcionadas ao campo, em 2003 foi instituído o Programa Nacional de Desenvolvimento Sustentável dos Territórios Rurais (PRONAT). Esse programa surgiu com o intuito de dinamizar as localidades mais empobrecidas, com apoio e incentivo a organização local e o fortalecimento institucional com base na gestão participativa (CARVALHO, 2012; LEITE; WESZ Jr., 2012; SABOURIN, 2007).

Em 2008 foi o Programa Territórios da Cidadania (PTC) (BRASIL, 2008). O PTC surgiu a partir da análise dos avanços e desafios observados com as experiências do PRONAT. O Programa Territórios da Cidadania possui uma diferença em relação às outras políticas públicas por ter como pano de fundo a articulação entre as diversas ações de governo e políticas públicas em torno de um mesmo território (BONNAL; KATO, 2012; FREITAS; DIAS; FREITAS, 2010). A partir deste programa, foram escolhidos 120 territórios, definidos por critérios tais como menor IDH, maior concentração de beneficiários do Programa Bolsa Família, maior concentração de agricultores familiares e assentados de reforma agrária, entre outros (BRASIL, 2008). Atualmente há 239 territórios rurais implementados no Brasil ${ }^{1}$.

O arranjo institucional construído pelas políticas públicas visando a consolidação da abordagem territorial do desenvolvimento rural são relevantes, pois a construção de um

\footnotetext{
${ }^{1}$ Ver em: Ministério do Desenvolvimento Agrário - MDA. Interessados podem apresentar projetos para territórios rurais. Disponível em: <http://www.mda.gov.br/sitemda/noticias/desenvolvimento-territorial\%C3\%A9-tema-de-plen\%C3\%A1ria-em-mato-grosso-do-sul>. Acesso em 28 out 2014.
} 
planejamento cujo esforço se pauta pela integração das instituições atuantes no meio rural era até então um cenário praticamente inexistente no contexto brasileiro, aliás, estas mesmas instituições são em diversos casos a origem dos conflitos, dada a uma estrutura social determinada ao longo do tempo (FAVARETO, 2010a).

Neste sentido, tem-se o Território Vale do Ribeira como escopo de pesquisa. Essa região está localizada entre os Estados de São Paulo e Paraná e possui o maior contínuo de Mata Atlântica do país, concentrando aproximadamente $23 \%$ de todos os remanescentes de biodiversidade do bioma. Além disso, a região possui uma das maiores concentrações de comunidades tradicionais, como quilombolas, caiçaras e comunidades indígenas.

A região foi um dos primeiros locais de expansão colonial no Brasil. No início de sua ocupação, a região caracterizou-se por ser estritamente um local de extração de metais preciosos e pelo incipiente ciclo econômico do arroz com base no trabalho escravo, onde sua produção era escoada através do Rio Ribeira de Iguape para o litoral sul do atual estado de São Paulo (VALENTIN, 2006). Ao longo da metade do século XX a região foi palco de diversas ações governamentais, porém, sem gerar ganhos privados e sociais à comunidade ribeirense, o que resultou no aumento de conflitos entre comunidades pobres e o Estado.

Apesar do recente histórico de promoção do surgimento de organizações sociais, além das políticas implementadas na região com o foco no desenvolvimento, tem-se um histórico ainda mais robusto de ações e políticas de desenvolvimento regional marcado pela intermitência e poucos efeitos positivos. Embora tenha aumentado a intensidade de políticas públicas nos últimos anos, o processo de implementação dessas políticas nem sempre e assimilada pelas dinâmicas sociais. Isto ocorre porque as políticas públicas não são implementadas no vácuo, mas em contexto de atores com posicionamentos diversos, que culminam em conflitos que nem sempre são mediados pelos implementadores das políticas, neste caso, os gestores públicos (BRAGA, 1998; COELHO et al., 2005; COELHO et al., 2006; COELHO; FAVARETO, 2008; FAVARETO; SCHORDER, 2007; GALVANESE, 2009; RESENDE, 2002: SILVA JÚNIOR, 2013).

Entretanto, a partir da literatura especializada produzida no Vale do Ribeira, percebemos que há poucas publicações que discutem centralmente as políticas públicas incidentes na região. Foram poucas as publicações encontradas que abordavam os efeitos das políticas públicas, ou conjunto de políticas que não as políticas ambientais (ADAMS et al., 2013; BRAGA, 1998; FAKIH, 2013; FUTEMMA et al., 2014, no prelo; GALVANESE, 2009; RESENDE, 2002; SILVA JÚNIOR, 2013). 
O breve contexto acima nos levou à seguinte questão de pesquisa: Porque os arranjos institucionais voltados à promoção da abordagem territorial do desenvolvimento rural não foram efetivos no Vale do Ribeira?

A hipótese construída em torno da pergunta norteadora é: As iniciativas em torno das políticas públicas de desenvolvimento territorial são comprometidas pelas descontinuidades entre ações políticas e pela ausência da estrutura institucional que seja compatível aos objetivos propostos pelos programas territoriais.

A hipótese foi elaborada com base na literatura revista, que elucida como os conflitos institucionais no âmbito das políticas territoriais (FAVARETO, 2010) e as estruturas históricas de manutenção de poder no meio rural, em especial no Vale do Ribeira (FAVARETO; SCHRODER, 2007; RESENDE, 2002), criam impedimentos para uma mudança de perspectiva voltada para o desenvolvimento territorial e da sustentabilidade.

Desta forma, o objetivo central desta dissertação passou pela análise dos limites e perspectivas que surgiram a partir da implementação dos programas públicos de desenvolvimento territorial, em específico o Programa Nacional de Desenvolvimento Sustentável dos Territórios Rurais e o Programa Territórios da Cidadania. Ademais, temos o os seguintes objetivos específicos:

- Caracterizar o tecido socioeconômico regional;

- Levantar as ações estatais voltadas ao desenvolvimento do Vale do Ribeira;

- Caracterizar os atores centrais no processo de implementação dos programas territoriais;

- Destacar os alcances e limites da atuação do Colegiado Territorial;

- Analisar o papel da assessoria territorial para a implementação das políticas.

Desta forma, esta dissertação esta organizada em quatro capítulos além desta introdução. No segundo capítulo nós construímos os caminhos e fluxos políticos voltados a consolidação da agricultura familiar como categoria de política pública, bem como a emergência da abordagem territorial como um importante aporte analítico para promover as transformações no meio rural.

No terceiro capítulo lançamos mão de alguns conceitos voltados à compreensão da análise em torno das políticas públicas. Foram reunidos elementos que abordam o processo de formulação da agenda e a implementação das políticas públicas, organizadas a partir do modelo de ciclos de vida da política. 
No quarto capítulo discutimos a luz da literatura quais foram os desafios e os avanços da abordagem territorial como uma categoria de política pública. Foram debatidos os principais programas territoriais implementados, considerando uma parte da análise à abordagem crítica, buscando evidenciar os limites e alcance das políticas públicas implementadas.

No quinto capítulo organizamos os resultados desta dissertação. Realizou-se um esforço de compreensão dos condicionantes estruturais e formas de reprodução social que moldam a interação social no Território Vale do Ribeira, bem como os impactos destes fatores na execução das políticas territoriais, em especial o Programa Territórios da Cidadania.

Por fim, foram encadeadas algumas sínteses direcionadas a conclusão desta pesquisa, além de recomendações a futuras pesquisas científicas a serem elaboradas tendo o Território da Cidadania Vale do Ribeira como caso.

\subsection{Procedimentos Metodológicos}

Os procedimentos metodológicos da pesquisa foram estruturados em quatro etapas: (a) análise do contexto; (b) entrevistas semi-estruturadas; e (c) Análise de documentos (b) revisão da literatura.

\section{A. Análise do contexto}

A análise do contexto socioambiental e institucional do Território do Vale do Ribeira se fez necessária. Entendendo análise de contexto como uma abordagem crítica de mão dupla entre os condicionantes históricos da formação social e da ação estatal na região com a atual estrutura do tecido social, político e econômico de um dado território (ESTANQUE, 2005), neste caso, o Território Vale do Ribeira. As idas a campo compõem a análise contextual tanto nas reuniões ordinárias no colegiado territorial do Vale do Ribeira - SP, como nos encontros, eventos e reuniões realizadas entre ONGs, comunidades quilombolas, agricultores familiares e os órgãos público. As atividades realizadas estão organizadas no Apêndice A.

A busca de atores chaves que de forma direta ou indireta seriam fontes de informações importantes voltadas a compreensão da efetividade do Programa Territórios da Cidadania se deu pelo método denominado "Bola de Neve" ou mais genericamente "Método da Cadeia de Referências". A "bola de neve é um método de amostragem não probabilista onde os 
interlocutores que participam inicialmente de um estudo indicam outros participantes e assim sucessivamente, objetivando chegar ao "ponto de saturação" Desta forma, o "ponto de saturação" é atingido quando os novos entrevistados passam a repetir os conteúdos já obtidos em entrevistas anteriores, sem acrescentar novas informações relevantes à pesquisa". A importância deste procedimento metodológico residiu na primeira fase de coleta de dados dada a otimização do tempo na identificação dos atores chaves que proporcionariam as informações sobre a pesquisa em questão, já que ao lançar mão deste método é uma forma de visualizar os atores mais específicos e relevantes (BERNARD, 2006).

\section{B. Entrevistas semiestruturadas}

Após um primeiro contato com a realidade da região do Vale do Ribeira, foram identificados alguns informantes-chave, cujas informações obtidas compõe o principal referencial empírico desta pesquisa. A entrevista foi um meio de coleta de fatos relatados pelos atores que são sujeitos-objetos da pesquisa e que vivenciam uma determinada realidade que se pretende apreender. A especificidade da entrevista semi-estruturada refere-se ao fato de utilizar-se um roteiro, mas tem-se a liberdade do entrevistador incluir novas questões (BERNARD, 2006).

Quanto aos informantes-chave, Bernard (2006) ressalta sua importância, uma vez que fornecem ao pesquisador percepções e interpretações de eventos, sugerem fontes diferentes para corroborar ou refutar evidências. A seleção dos entrevistados se balizou por atores envolvidos ou que tinham conhecimento do processo de gestão do Território Vale do Ribeira $-\mathrm{SP}$.

C. Análise dos documentos

A investigação documental também faz parte dos procedimentos metodológicos dessa pesquisa, foram olhadas as atas das reuniões ordinárias e extraordinárias do conselho gestor. A pesquisa documental é uma fonte de informações complementar, auxiliando no melhor

entendimento dos dados e corroborando evidências coletadas por outras técnicas e fontes (SÁSILVA; ALMEIDA; GUINDANI, 2009).

\section{Revisão da literatura}

$\mathrm{Na}$ revisão da literatura nos permitimos a utilizar abordagem interdisciplinar, que prega o processo de pesquisa, de conhecimento, de levantamento, análise e sínteses da realidade por diferentes campos disciplinares, em trabalho conjunto e interligado por um 
objetivo uno: o de compreender e apontar direções a resoluções das problemáticas socioambientais (ROCHA, 2003).

Deste modo, utilizamos a abordagem territorial do desenvolvimento rural como centro analítico da nossa dissertação. Esta abordagem foi complementada com os referenciais da análise da política pública e dos modelos que organizam as etapas de formulação e implementação das políticas públicas. Esta articulação entre as duas abordagens mostrou-se importante para identificar os principais êxitos e obstáculos dos programas territoriais no Território Vale do Ribeira. 


\section{CAPÍTULO 2 - A ABORDAGEM TERRITORIAL DO DESENVOLVIMENTO RURAL}

\subsection{Uma releitura do meio rural}

O debate sobre as novas formas de analisar o meio rural surgiram em meio à constatação dos limites sociais e ambientais promovidos pelo modelo fordista de desenvolvimento, estabelecido a partir da segunda metade do século XX (BEDUSCHI; ABRAMOVAY, 2004). No contexto posterior à Segunda Guerra Mundial, os Estados-nação e organismos internacionais organizaram diretrizes de desenvolvimento baseadas, por um lado, na premissa da construção do estado de Bem-Estar social nos países do norte, e, por outro lado, na proposta de induzir o crescimento econômico por meio da industrialização e modernização agrícola nos países em desenvolvimento (DUARTE, 2000).

A execução do modelo modernizante nos países da América Latina impulsionou significativamente o processo de industrialização e a modernização da agricultura. O resultado da elevação dos ganhos financeiros obtidos ao longo desta etapa de desenvolvimento promoveu o surgimento de um importante parque industrial no Brasil, além de elevar sobremaneira a produção e a produtividade agrícola (DUARTE, 2000; SCHNEIDER, 2010).

No entanto, este modelo de desenvolvimento pautado principalmente por questões econômicas, relegou as condicionantes, enraizadas historicamente, dos fatores que contribuíam para um quadro de desigualdade. Sob tais condições, o crescimento econômico do período não resultou na redução da disparidade socioeconômica, ao contrário, agudizou os problemas estruturais que promoviam a segregação econômica entre ricos e pobres. Desta forma, o período em questão foi marcado pela chamada "modernização conservadora", que pode ser entendida como uma estratégia definida entre o Estado e as elites da época, que buscava expandir o financiamento e desenvolvimento econômico sem alterar as bases estruturais mantenedoras das disparidades sociais (PIRES; RAMOS, 2009).

Os efeitos da modernização promoveram mudanças drásticas nas áreas urbanas, assim como no campo, sendo que, neste último, foram impulsionadas a partir do que se convenciona denominar revolução verde. Este modelo efetivou um sistema de produção agrícola baseado em aumentos significativos de produtividade diretamente dependente de insumos industrializados. Desta forma, a preparação do solo com o uso mais intensivo de máquinas agrícolas, o cultivo a partir da seleção de variedades geneticamente modificadas de alto rendimento, e o aumento da produtividade com o uso de agrotóxicos atrelou fortemente a 
agricultura à indústria (BUANAIN; ROMEIRO; GUANZIROLI, 2003; MAZOYER; ROUDART, 2010; SCHNDEIDER, 2010).

A revolução verde atingiu seus objetivos permitindo o aumento significativo nos rendimentos e produção de grãos no Brasil, e nos países em desenvolvimento em geral (FAVARETO, 2010a). Contudo, o processo não foi ausente de custos sociais, já que somente os agricultores mais organizados aproveitaram as benesses deste processo, excluindo assim a maior parte dos produtores com menor estrutura. Os desdobramentos deste movimento no campo atuariam de maneira decisiva na reconfiguração do meio rural, aprofundando os níveis assimétricos de desenvolvimento entre grupos e setores:

\footnotetext{
"Paralelamente às experiências de reforma agrária - ou de sua frustração como no caso brasileiro -, ocorre uma rápida modernização do setor agrícola nesses países, com uma forte expansão da produção, um aumento do comércio e uma urbanização rápida e crescente. Mas o efeito da chamada revolução verde para os pobres rurais foi nulo ou negativo. Uma das consequências foi a profunda heterogeneização desses espaços: alguns alcançam um modelo de integração competitiva enquanto outros aprofundam a situação de marginalização e decadência". (FAVARETO, 2010a, p. 303).
}

O movimento de modernização agrícola resulta numa mudança estrutural das diferentes regiões rurais brasileiras. O campo se transformou num setor produtor de alimentos a baixo custo, subordinado ao movimento de expansão urbana e industrial. Para as populações pobres do campo, restaram as opções de conformação com a condição de reserva barata de mão-de-obra temporária nas grandes fazendas, ou a tentativa de buscar oportunidades de renda no crescente setor industrial (GRAZIANO, GÓMEZ; CASTAÑEDA, 2010). Desse quadro emerge o movimento de êxodo rural e de inchamento urbano com o crescimento das periferias ao longo da década de 1970 e 1980 (GROSTEIN, 2001).

Outra consequência do processo de modernização no campo foi a sua execução sem estar calcada numa jurisdição e regulamentação ambiental específica, o que contribuiu para a emergência de diversos problemas socioambientais para as áreas e populações rurais (VEIGA; EHLERS, 2009). As mudanças estruturais causadas principalmente pela intensificação do uso de insumos como defensivos e fertilizantes químicos, acentuada pela necessidade do aumento da escala de produção, se tornou um dos principais promotores da degradação dos recursos naturais e da biodiversidade:

“Comparáveis aos impactos das mudanças de uso dos solos são os estragos causados pela homogeneização, isto é, as perdas de diversidade provocadas pela padronização dos sistemas de produção agropecuários. Além da diminuição do número de espécies e da variedade genética das plantas utilizadas, também ocorre uma dramática redução do número de outras espécies, como as bactérias fixadoras de nitrogênio, os fungos que facilitam a absorção de nutrientes, predadores de pragas, polinizadores etc. Enfim, mingua a base genética de inúmeras espécies que coevoluiram durante séculos ou milênios. Simultaneamente, águas superficiais e 
subterrâneas são contaminadas, tanto pelo uso crescente dos insumos básicos dessa conversão (fertilizantes químicos e agrotóxicos), quanto pela excessiva concentração da pecuária. Além dos problemas de saúde, essa falta de diversidade funcional compromete a resistência e a resiliência dos agroecossistemas, aumentando a sua vulnerabilidade às pragas, secas e outras mudanças climáticas" (VEIGA; EHLERS, 2009, p. 6).

Ademais, a revolução verde não jogou a favor da conservação dos remanescentes de biodiversidade em geral, como apontam Veiga e Ehlers (2009, p.6):

"É justamente esta artificialização agropecuária aliada à expansão da fronteira agrícola que vêm dilapidando a diversidade biológica da Floresta Tropical Atlântica, dos Cerrados, da Caatinga e, mais recentemente, da Floresta Amazônica".

A situação contrastante de um rápido crescimento econômico em detrimento da formação de um tecido social mais equilibrado e justo tem seu ponto de inflexão na década de 1980. Se esta década é conhecida como "perdida" devido à explosão da crise econômica no mundo, foi também uma década marcada por intensas reflexões e o surgimento de novos olhares direcionados a construir outra perspectiva de desenvolvimento. Curiosamente, no campo brasileiro esta é a década em que os rendimentos agrícolas, diferente de outros setores, aumentaram significativamente.

\subsection{A agricultura familiar como uma nova categoria de análise}

A crise econômica em nível mundial que emerge na década de 1980 afeta de sobremaneira os países em desenvolvimento. No plano mundial, surge o debate sobre as limitações do estado tanto na sua função de promotor do crescimento econômico, como na função de indutor da redução das assimetrias sociais (SCHNEIDER, 2010).

O processo de redemocratização que culminou na Constituição de 1988 respondia a amplas reivindicações, principalmente dos movimentos sociais, pela descentralização administrativa e pelo aumento do poder dos entes federados na tomada de decisão (ORTEGA, 2012). Desse modo, o novo texto constitucional definiu competências exclusivas para os Estados e os Municípios. Isto promoveu o fortalecimento, em tese, dos entes federados, exemplificado com a criação de dispositivos para obtenção de recursos via impostos e os repasses de verbas pela União aos Estados e Municípios (SOUZA, 2005).

No campo, o momento em questão foi profícuo para o ressurgimento da participação da sociedade civil. Nesse contexto, os movimentos sociais foram responsáveis por organizar as camadas mais pobres em torno das demandas historicamente reprimidas (SCHNEIDER, 2010). No final da década de 1980 houve o fortalecimento dos movimentos sociais e a 
abertura para um diálogo entre estes e o Estado no processo de redemocratização do Brasil. As reivindicações dos movimentos sociais, aliadas ao desgaste do regime anterior, refletiram na criação de mecanismos de interlocução entre gestores públicos e sociedade civil, tais como os conselhos gestores.

Há inúmeros exemplos deste novo formato de diálogo entre sociedade civil e Estado, como a experiência de gestão municipal fundamentada na participação cidadã e no desenvolvimento sustentável durante a passagem de Dirceu Carneiro como prefeito do município de Lajes, Santa Catarina, entre 1976 e 1982 (ALVES, 1980). Ademais, surgiram experiências localizadas, a nível municipal, como o Conselho de Saúde da Zona Leste do município de São Paulo, reunindo gestores públicos e sociedade civil visando melhorar o controle social dos recursos públicos e encaminhar propostas mais permeáveis às demandas sociais $(\mathrm{GOHN}, 2006)$.

Considerados como uma das maiores inovações institucionais da democracia brasileira, os conselhos gestores foram recepcionados pela Constituição Federal de 1988 como espaços privilegiados de participação social sob a ótica da esfera pública. Ou seja, a formação de espaços de diálogos entre os diversos atores públicos e privados visando facilitar os governos tomarem decisões de interesse à construção do bem comum (ABRAMOVAY, 2000b; TENÓRIO, 2005).

Soma-se ao fato da emergência dos conselhos gestores decorrente do processo de abertura econômica no início da década de 1990, baseado no Consenso de Washington (DUARTE, 2000), o qual reposiciona a importância dos entes privados e dos mercados. Este reposicionamento é motivado pela desconfiança em relação à centralidade do Estado como único promotor de bens privados e sociais. Neste sentido, a proposta tinha a premissa de realocar o papel do Estado, de promotor direto de desenvolvimento a um indutor do ambiente mais propício aos agentes privados, visando a alocação de recursos para uma forma, supostamente, mais eficiente (FREITAS; DIAS; FREITAS, 2010).

Em síntese, vemos um contexto no qual há a emergência de diversos atores sociais, motivada pela crise gerada pelo formato centralizador da gestão estatal vigente. A guinada para um estado democrático também reflete a perda deste na capacidade central de atuação. Portanto, legitimam-se novos atores que passam a influenciar o debate público com suas demandas e a formulação das políticas públicas no ambiente democrático pós-88.

Neste contexto de intensa transformação, o meio rural revigora-se como objeto de estudo por parte da academia e intelectuais. A ação centralizada e intervencionista por parte do Estado havia afastado os estudiosos dedicados ao tema, pois as ações realizadas por parte 
do governo na época visava um caráter exclusivamente normativo e de uso político. Somente na década de 1990 inicia-se uma reaproximação entre o meio rural e a academia, reaproximação esta marcada por abordagens inovadoras (SCHNEIDER, 2010).

No início da década de 1990, surgem duas obras de relevante contribuição acadêmica as quais traziam um novo olhar sobre o meio rural, dos professores Ricardo Abramovay, e José Eli da Veiga lançadas: Paradigmas do Capitalismo agrário em questão e $O$ desenvolvimento agrícola, uma visão histórica, respectivamente. Aliadas aos estudos posteriores coordenados por Hugues Lamarche, lançados em dois volumes intitulados Agricultura Familiar, estas obras foram decisivas para inserir no debate acadêmico uma nova categoria de análise: a agricultura familiar (FAVARETO, 2006a).

As obras em questão afirmavam que a configuração moderna da agricultura capitalista dos países centrais tinha forte relação com formato social de trabalho baseado na gestão familiar da propriedade, cuja grande diversidade entre as unidades familiares estava associada, principalmente, ao grau de integração aos mercados. Apesar de tal diversidade, o elemento central que a une é o caráter da empresa específica, a empresa familiar (FAVARETO, 2006a; SABOURIN, 2007).

Neste sentido, as obras em questão iniciam uma profunda releitura sobre o impacto da agricultura familiar como categoria analítica. Segundo Favareto (2006a, p. 16):

\footnotetext{
"As novas ideias por elas trazidas tiveram reflexos profundos e imediatos não só sobre o campo propriamente acadêmico, como também sobre o discurso de movimentos sociais e da burocracia governamental ligada à agricultura, e foram acompanhadas por movimentos de igualmente significativa repercussão".
}

Deste momento em diante, percebe-se a proliferação de trabalhos relacionados à compreensão do universo da agricultura familiar. Primeiramente, temos o estudo realizado por um projeto de cooperação entre a FAO e o INCRA em 1994 sobre as tipologias e formas sociais de produção no meio rural. Este estudo foi uma das bases do Programa Nacional de Fortalecimento da Agricultura familiar - PRONAF (FAVARETO, 2006a).

Em seguida, outro projeto foi realizado entre os anos de 1996 e 1998 por meio da articulação entre organismos europeus de cooperação e organizações sindicais de representação da agricultura familiar. O denominado Projeto CUT/CONTAG foi coordenado pelo professor José Eli da Veiga e tinha o objetivo de identificar as dinâmicas, denominadas naquele momento de meso-regionais, com vistas a facilitar a atuação das organizações sindicais. Segundo Favareto (2006a, p. 17):

"Esta pesquisa mostrou um campo novo de preocupações que viria a se delinear melhor, no Brasil, na virada para a década atual [2000]: A necessidade de se entender as articulações entre formas de produção, características morfológicas dos 
tecidos sociais locais e dinâmicas territoriais de desenvolvimento; ou na mesma direção, as articulações entre espaços considerados rurais e urbanos”.

Este estudo foi importante no sentido de mostrar que a dinamização econômica da agricultura familiar tem como fator fundamental a configuração regional na qual as famílias estão inseridas, ou seja:

"um entorno econômico diversificado e dotado de infraestrutura e um desenho que permita a criação de empregos que possam abrigar o trabalho excedente da atividade agrícola e, inversamente absorver nas unidades familiares o trabalho descartado nas cidades" (FAVARETO, 2006a, p. 17).

Um aspecto interessante das organizações sindicais é o seu deslizamento na forma de atuação e nas suas bandeiras políticas. Se na década de 1980 as organizações sindicais empunhavam a bandeira da reforma agrária e dos direitos trabalhistas, na década de 1990 esses discursos são alterados pela reivindicação por um "projeto alternativo de desenvolvimento rural baseado na agricultura familiar" (FAVARETO, 2006b). Podemos observar este momento de forma mais concreta pelo exemplo do expressivo aumento de assentamentos disponibilizados ao MST pelo governo federal no início da década de 1990, demonstrando o reposicionamento na relação entre movimentos sociais do campo e o Estado (VEIGA, 2000).

Inspirado no Projeto CUT/CONTAG, outro estudo de grande impacto foi realizado: o Projeto Rurbano, coordenado por José Graziano da Silva. O estudo focava nas formas de obtenção de renda e os tipos de empregos do meio rural entre as décadas de 1980 e 1990 . Os resultados deste trabalho surpreenderam os especialistas, pois demonstravam o surgimento de um novo rural brasileiro, marcado principalmente pela identificação da redução do êxodo rural e a diversificação de atividades produtivas e dos empregos não agrícolas (GRAZIANO DA SILVA; GROSSI; CAMPANHOLA, 2005).

O Projeto Rurbano teve o exito de elucidar a complexidade do rural brasileiro. Enquanto as atividades agrícolas e não agrícolas impulsionaram os estudos sobre a pluriatividade (SCHNEIDER, 2003) e a multifuncionalidade (SACCO DOS ANJOS; CALDAS, $2009^{2}$ ), as diferentes formas de ocupação do território aliadas a sua interação com

\footnotetext{
${ }^{2}$ Os autores recuperam historicamente os conceitos de pluriatividade e multifuncionalidade e observam que a pluriatividade surge em detrimento do conceito de part time farming nos Estados unidos, pois somente o tempo de trabalho não servia de critério para compreensão da complexidade do meio rural. Já o conceito de multifuncionalidade surge como contraposição à crise dos excedentes de produção, principalmente na Europa. Logo, a pluriatividade (forma de organização da produção diversificada e a realização de trabalhos dentro e fora da unidade produtiva) e a multifuncionalidade (a capacidade do campo em produzir externalidades positivas a partir de atividades voltadas a preservação do patrimônio cultural e paisagístico, conservação dos recursos naturais, etc.) se originam com a mesma preocupação e são conceitos complementares em termos de análise. Às leitoras e leitores interessados, ver Sacco dos Anjos e Caldas, (2009).
} 
a paisagem entrariam em convergências com os estudos relacionados à identificação das amenidades rurais (fragmentos naturais, áreas manejadas, tradições culturais, entre outros) como trunfo para desenvolver atividades não agrícolas (VEIGA; EHLERS, 2009). Tais características permitiam questionar a visão predominante sobre o meio rural como sinônimo de atraso e a sua dicotomia em relação às cidades perdiam o valor explicativo diante a noção de um continnum entre ambos (SCHNEIDER 2010).

A amostra de estudos supracitados ilustram a consolidação do termo na agenda de pesquisa e o seu reflexo nos movimentos sociais e governos da época. A contínua solidificação da agenda de pesquisa sobre a agricultura familiar é fundamental para elevar o tema na agenda pública no Brasil (FAVARETO, 2006a; KARAM, 2012; SCHNEIDER, 2010).

O processo de descentralização e o amplo debate que se seguia em torno de um novo modelo de desenvolvimento para o campo foi propício à criação de propostas inovadoras. Tais propostas foram aceitas pelos movimentos sociais, os quais alteraram a sua forma de atuação reativa para um formato participativo e propositivo (ABRAMOVAY; MAGALHÃES, SCHRODER; 2010). Também emergem várias organizações da sociedade civil como ONGs, associações cooperativas, de tal forma que os governos viram como positivo a atuação destes movimentos e da academia na geração de temas para agenda de desenvolvimento aliados à perspectiva de descentralização e controle social da política pública (SCHNEIDER, 2010).

Pela perspectiva dos governos, a prioridade da agenda estar calcada na estabilização econômica foi interposta por uma guinada de esforços voltados à melhoria de qualidade de vida no meio rural. Em 1991 é lançado o Regime de Previdência Social, que equiparou as aposentadorias rurais às urbanas, o que se traduzia num aumento de $50 \%$ do valor das aposentadorias rurais, além de reduzir a idade mínima e o reconhecimento do direito para homens e mulheres (ADAMS et al., 2013; CARVALHO FILHO, 2008). Outra política importante foi a implantação do Programa Saúde da Família em 1994, que universalizou o atendimento de saúde básica para as populações rurais (ADAMS et al., 2013).

A política pública de maior impacto promulgada na década de 1990, voltada ao meio rural, foi o PRONAF. Este programa surge a partir do Programa de Valorização da Pequena Produção Rural - PROVAP, lançado em 1994, no governo Itamar Franco (1992-1994). No governo Fernando Henrique Cardoso (1995-2002) este programa sofre uma reformulação que, em 1996, resulta no PRONAF. É importante ressaltar que o PRONAF surgiu em muito como produto das reivindicações das organizações de trabalhadores e agricultores do meio rural que 
buscavam apoio institucional e facilidades ao acesso ao crédito rural (SCHNEIDER; MATTEI; CAZELLA, 2004). A implementação do PRONAF fora acompanhada de outra inovação, os Conselhos Municipais de Desenvolvimento Rural Sustentável - CMDRSs. Esses conselhos tinham a função de elaborar os Planos Municipais de Desenvolvimento Rural Sustentável (PMDRS) como critério de pleitos a projetos no âmbito do PRONAF infraestrutura (ABRAMOVAY; VEIGA, 2000).

Em 1999, houve uma importante inovação com a criação do Conselho Nacional de Desenvolvimento Rural Sustentável - CNDRS. Este mecanismo fora criado com o intuito de formular o chamado Plano Nacional de Desenvolvimento Rural Sustentável - PNDRS. A inovação se dava pela abertura ao diálogo com os movimentos sociais rurais, no intuito de construir o plano com apoio e legitimidade da sociedade civil. Devido ao ineditismo de se montar uma arena de interlocução com sociedade civil a nível federal, houve atraso na indicação dos nomes para as cadeiras. O CNDRS funcionou de forma efetiva somente a partir de 2001 (IPEA, 2012).

\subsection{A abordagem territorial do desenvolvimento rural}

Os estudos descritos acima relacionados à emergência da nova ruralidade tinham inspiração em experiências de desenvolvimento regional que estavam ocorrendo nos países da Europa e Estados Unidos. Estes temas formaram uma profícua agenda de pesquisa das Ciências Sociais voltadas à compreensão da natureza territorial do desenvolvimento (BEDUSCHI; ABRAMOVAY, 2004). Uma das experiências que fundamentaram o enfoque territorial surgiu na década de 1970 com o debate em torno dos distritos industriais. Os estudos fundamentados nas correntes da Geografia Econômica ${ }^{3}$ e da Economia Regional ${ }^{4}$ realizados destacavam a importância da proximidade entre empresas e instituições na geração de externalidades econômicas positivas no território e o papel da ação coletiva na difusão do conhecimento, das técnicas e tecnologias no desenvolvimento de máquinas e da criação de um importante mercado local de empregos (BEDUSCHI; ABRAMOVAY, 2004).

As evidências em torno dos distritos industriais italianos mostravam que as especificidades desta experiência residiam na forte identificação dos agentes econômicos e sistemas produtivos com os territórios nos quais estavam localizados. Esses elementos demonstravam a emergência de um novo modelo de organização industrial diferente das grandes plantas industriais e a produção em massa padronizada, características do fordismo. $\mathrm{O}$

\footnotetext{
${ }^{3}$ Às leitoras e leitores interessados, ver Redding, 2010.

${ }^{4}$ Às leitoras e leitores interessados, ver Souza, 1981.
} 
novo modelo, denominado especialização flexível, tinha a vantagem de promover diversificação produtiva, além de criar maior permeabilidade às mudanças de demanda e na capacidade de absorção e criação de inovações (BEDUSCHI; ABRAMOVAY, 2004; SCHNEIDER, 2009).

O modelo de industrialização difusa refletia a necessidade das empresas em se adaptar as reduções de custos, mas também as exigências de demandas diferenciadas. Tal necessidade conduziria as firmas a experimentarem arranjos descentralizados na produção de bens e serviços. Segundo Beduschi e Abramovay (2004, p. 41):

\footnotetext{
"A questão chave da economia - a coordenação entre atores autônomos e soberanos por meio de um sistema sobre o qual nenhum deles exerce um controle planejado transfere-se para o interior mesmo da organização produtiva. Nas formas centralizadas de organização industrial, a coordenação entre as diferentes etapas da fabricação era exercida por meio de hierarquia fixa e verticalizada. O que muda agora é a própria natureza da cooperação entre atores econômicos, em virtude da organização produtiva descentralizada e coordenada por sistemas integrados em rede."
}

A partir da experiência do arranjo produtivo italiano, três importantes fatores são destacados:

- A aproximação de empresas visando à cooperação aumenta a potencialidade de geração de produtos diversificados, respondendo à demandas cada vez mais diversificadas e exigentes, ou seja, a interação de diferentes atores para o que chamamos de construção social dos mercados (ABRAMOVAY, 2000a);

- Relacionado ao primeiro fator, o ambiente de cooperação entre agentes econômicos permite intercâmbio de experiências e conhecimentos organizacionais, que agindo de forma coordenada entre indivíduos e empresas promovem a aprendizagem por interação (BEDUSCHI; 2007; BEDUSCHI; ABRAMOVAY, 2004);

- $\quad$ E, por último, a construção de um arranjo produtivo formado a partir da cooperação entre agentes econômicos de uma mesma região que se utilizam das especificidades locais aliados aos processos localizados de aprendizagem, tem como reflexo a necessidade da abordagem territorial (BEDUSCHI; ABRAMOVAY, 2004).

Outra experiência, também realizada na Itália, analisava os determinantes que levavam os atores a realizarem ações cooperadas e recíprocas visando o fortalecimento das chamadas economias de proximidades (ABRAMOVAY, 2002). Utilizando o conceito de capital social, Putnam (1996) realiza um estudo sobre o desempenho institucional das regiões italianas e evidencia que as comunidades com dinâmicas mais virtuosas são justamente 
aquelas que construíram ao longo do tempo um alto nível de confiança, solidariedade horizontal e rede de cooperação entre os atores. Ao contrário, as regiões deprimidas, devido ao seu baixo nível de relações de confiança são incapazes de agir em consonância a promoção do bem comum (PUTNAM, 1996).

Tal abordagem resultou num impacto entre os estudiosos, sendo inclusive alvo de críticas devido ao seu caráter fatalista. Contudo, a evidência do capital social nos processos de fortalecimento da cooperação refletiu no sentido de incluir o conceito numa categoria de análise em relação a importância dos laços cooperativos como instrumentos de redução da pobreza em países em desenvolvimento (ABRAMOVAY, 2002). Desta forma, tanto os trabalhos em torno dos distritos industriais como as pesquisas direcionadas a compreensão e aplicação do capital social como abordagem teórico-metodológica, surgiu uma literatura extensa sobre a relação dos sistemas produtivos locais, inovação e desenvolvimento local inscritos no debate dos territórios. Neste sentido, território passa a ser visto cada vez mais como um ator social, já que o mesmo não se mostra um simples receptáculo neutro de atuação de empresas, indivíduos, coletividades e estado, ao contrário, são agentes que interagem e intercambiam conhecimentos que potencializam a atuação de empresas, coletividades e governos na promoção de círculos virtuosos de desenvolvimento (BEDUSCHI; ABRAMOVAY, 2004).

A inovação da abordagem territorial como categoria analítica pode ser estabelecida em quatro dimensões:

i) A abordagem territorial tende a renunciar ao horizonte setorial de visão estritamente agrária, além de ampliar a perspectiva da existência de outros atores além dos agricultores. Este reconhecimento leva a duas consequências: a) ao reconhecimento dos limites das reais dimensões das regiões rurais no Brasil. Este reconhecimento refletiu nos estudos sobre as dinâmicas rurais como o Projeto Rurbano (GRAZIANO DA SILVA; GROSSI; CAMPANHOLA, 2005) e, b) no ressurgimento do modelo da interação social como variável analítica, que enfatiza a cooperação e compartilhamento de conhecimento entre os atores como fator explicativo do desenvolvimento territorial (ABRAMOVAY, 2006). Este fator é preponderante para motivar a inovação em ambientes de aprendizagem (BEDUSCHI; ABRAMOVAY, 2004).

ii) A noção de território desfaz a confusão entre os processos de desenvolvimento e o crescimento econômico estrito. Quando tal confusão é desfeita, percebe-se que a desigualdade social num determinado território não pode ser explicada somente pela insuficiência de renda agropecuária, já que há outras atividades além das agrícolas que 
possibilitam a obtenção de. Logo, a abordagem territorial requer a análise de como as instituições moldam e são moldadas pelas forças sociais (ABRAMOVAY, 2006);

iii) A abordagem territorial estimula os estudos empíricos relacionados a identificar e compreender a atuação das diversas organizações e atores nos territórios em conjunto com o poder público em torno das arenas de tomada de decisão. Os estudos dos mecanismos de governança pública e privada são relevantes objetos de estudos que evidenciam a capacidade dos colegiados em convergir os diversos interesses em direção ao planejamento territorial (ABRAMOVAY, 2006);

iv) Por fim, a abordagem territorial enfatiza a relação entre sistemas sociais e ecológicos, ou seja, como determinadas sociedades estabelecem relações com os ecossistemas de forma a manter sua unidade sociocultural ao longo do tempo em conjunto com um uso racional dos recursos naturais. São estes estudos que permitem uma contraposição à perspectiva limitada de desenvolvimento quando restrita somente ao crescimento econômico. Assim, "Os territórios são o resultado da maneira como as sociedades se organizaram para usar os sistemas naturais nos quais se apoiam sua reprodução, o que abre um interessante campo de cooperação entre as ciências sociais e naturais para o conhecimento desta relação" (ABRAMOVAY, 2006).

Para Sachs (2007), para os territórios com ampla diversidade sociocultural e ecológica se faz necessária pesquisas científicas voltadas às áreas da Ecologia Humana e da Etnobiologia $^{5}$. A ênfase nestas áreas recai na necessária melhoria das pobres e limitadas estratégias de conservação, além de ampliar o leque de potenciais usos dos recursos naturais (VEIGA; EHLERS, 2009).

A criação de estratégias de uso racional $^{6}$ dos recursos naturais joga por terra a dicotomia entre o economicismo, que prega o raciocínio de planejamento em curto prazo, e o ecologismo, que "em nome de um conservacionismo intransigente e concebido para toda a eternidade, chega a renegar os fundamentos antropocêntricos de toda filosofia social" (SACHS, 2007, p. 80). A oportunidade do uso racional da biodiversidade brasileira, em vez

\footnotetext{
${ }^{5}$ Às leitoras e leitores interessados em ampliar o conhecimento sobre a Ecologia Humana, ver capítulo I de Adams (2000).

${ }^{6}$ Favareto (2006c) afirma que atualmente há um processo de racionalização da vida rural. Esse processo se expressa nas formas de condução do cotidiano que cada vez mais são pautadas pela ação racional, tanto com relação a fins como em relação a valores, e cada vez menos pautado pela tradição ou por fórmulas mágicas de relação com o mundo. As instituições são entendidas como as mediadoras de conflitos e interesses para a materialização de compromissos formais e informais. Assim, o rural conforma um novo sentido, onde é possível a condução da vida no meio rural a partir de conteúdos sociais nas quais as estruturas cognitivas e os espaços que conformam a interação não respondem mais ao isolamento e as raízes agrárias, ao contrário, responde cada vez mais pela aproximação entre o urbano e o rural, entre a sociedade e a natureza. Às leitoras e leitores interessados, ver Favareto (2006c).
} 
de ser uma ameaça aos ecossistemas, é uma estratégia para conservação. A manutenção da biodiversidade permite o desenvolvimento de atividades relacionadas à produção de biomassa e biotecnologia. As regiões que ainda não sofreram com o processo de crescimento econômico com destruição dos atrativos naturais possuem um verdadeiro trunfo para gerar renda a partir de atividades turísticas em concomitância com atividades estritas de conservação e pesquisas científicas (VEIGA, 2001).

A abordagem territorial aliada ao novo discurso de ruralidade e da sustentabilidade foi se consolidando progressivamente devido à amplitude que os temas alcançaram no ambiente acadêmico. Além disso, a abordagem territorial foi incorporada às diretrizes de diversas agências e organismos multilaterais, como a Organização das Nações Unidades para a Agricultura e Alimentação (FAO), o Banco Mundial, a Comissão Econômica para a América Latina (Cepal), o Banco Interamericano de Desenvolvimento (BID), o Instituto Interamericano de Cooperação Agrícola (IICA) e Organização para a Cooperação e o Desenvolvimento Econômico (OCDE).

Tais organismos possuem grande influência nas tomadas de decisões dos países membros, principalmente a porção dos países em desenvolvimento. Há relação de intercambio de conhecimentos e experiências entre tais organismos, Estados-nação e a comunidade acadêmica, com o intuito de criar mecanismos de planejamento e tomada de decisão mais refinados (FAVARETO, 2010a). Enquanto no Brasil o debate sobre a abordagem territorial como enfoque promotor de dinâmicas virtuosas no meio rural se consolidava no discurso da academia, dos movimentos sociais e dos governos, surgiam experiências na Europa e Estados Unidos de implementação de políticas de caráter territorial.

A principal experiência de planejamento e ações a partir da abordagem territorial surgiu com a implementação do Programa de Ligação Entre Ações de Desenvolvimento da Economia Rural (Programa LEADER). Lançado em 1991, o programa surgiu no intuito de promover novas formas de planejamento para o desenvolvimento dos territórios, priorizando em seu início áreas rurais em processo de estagnação econômica e redução demográfica (BEDUSCHI; ABRAMOVAY, 2004; GUIMARÃES, 2013).

As ações inovadoras do programa tinham base na construção ascendente do planejamento (bottom-up) calcado no ajustamento estrutural das regiões, na participação popular e na integração multissetorial, ou seja, "a combinação de atividades de setores econômicos diferentes ou de atividades públicas e privadas num único objetivo e coerência estratégica entre projetos diferentes que partilham o mesmo objetivo" (GUIMARÃES, 2013, p. 145). 
O Programa LEADER construiu um método de abordagem direcionado a regiões com áreas de tamanho limitado e identidade reconhecida e promovia o envolvimento ativo dos atores locais em todas as fases de implementação. Essa articulação entre os atores eram promovidas pelo Grupo de Ação Local (GAL), que tinham o intuito de animar os atores locais em perspectiva à criação de um projeto territorial. Este projeto, portanto, lançaria as diretrizes, a partir da construção de modelos mentais partilhados, do desenvolvimento dos territórios (BEDUSCHI; ABRAMOVAY, 2004).

Com a identificação de regiões com diferentes graus de desenvolvimento foi possível o estabelecimento de diferentes estratégias: em regiões mais deprimidas e com baixo capital social, eram estimulados projetos de formação de lideranças locais; já nas áreas mais com maior estrutura e relações de confiança, os projetos estimulados avançavam para construção de consensos em torno das estratégias de desenvolvimento local (BEDUSCHI; ABRAMOVAY, 2004).

Outra inovação do programa foi o rompimento com a lógica de balcão de projetos, ou seja, a lógica de aprovação de propostas sem qualidade pela falta de um melhor. Desta forma, promoveu-se a competição entre projetos buscando garantir somente a aprovação daqueles cujo conteúdo apresentava intenções mais estruturadas e melhor relacionadas às metas dos territórios (BEDUSCHI; ABRAMOVAY, 2004). Além disso, devido a grande heterogeneidade dos territórios sob o Programa LEADER, tanto o processo de mobilização como o de elaboração de projetos adaptado as diferentes realidades só foram possíveis devido ao alto grau de flexibilidade e liberdade nos modos de operacionalização do programa.

Portanto, a formulação de projetos territoriais tem o intuito de alterar as formas de repasses de recursos públicos. O planejamento em caráter participativo reduz a possibilidade de privilégios a setores da sociedade mais influente e amplia as possibilidades de um fomento com o real objetivo de desenvolvimento dos territórios, a partir do financiamento de projetos articulado com metas planejadas de médio e longo prazo. Essas propostas são agrupadas sob a roupagem de uma abordagem territorial do desenvolvimento rural, que buscava o alinhamento dos esforços das políticas para a dinamização dos territórios com vistas a eliminar a pobreza e promover seu desenvolvimento. Essa abordagem enfatizava "el carácter multissetorial, territorial y descentralizado que deben tener las estrategias de desarollo rural y de lucha contra la pobreza." (SCHEJTMAN; BERDEGUÉ, 2004, p. 18).

Essa mudança de perspectiva do desenvolvimento rural levaria a recalcular o peso das especificidades locais e/ou regionais a serem consideradas como elementos fundamentais na formulação das políticas públicas "pensadas a partir da realidade econômica, social, 
cultural e institucional de determinado espaço" (OLIVEIRA, 2002 apud HESPANHOL, 2010, p. 126) e não mais apenas considerando as atividades desenvolvidas setorialmente, como no caso da agricultura.

Em suma, são considerados alguns pontos fundamentais dessa nova estratégia: a dimensão territorial com todos os condicionantes envolvidos nesse recorte; a consideração da heterogeneidade social dentro dos territórios; a consideração dos empregos agrícolas e não agrícolas nas propostas; a ênfase na integração dos setores agrícola, industrial e de serviços; os vínculos entre o campo e a cidade; e por último, o desenvolvimento de instituições no espaço para efetivarem seu Desenvolvimento Territorial Rural.

De acordo com Schejtman e Berdegué (2004, p. 30): "Definimos Desarrollo Territorial Rural como un proceso de transformación productiva e institucional de un espacio rural determinado cuyo fin és reducir la pobreza rural.".

Assim, o Desenvolvimento Territorial Rural sustenta-se em dois eixos relacionados: a transformação produtiva e o desenvolvimento institucional. A transformação produtiva refere-se à articulação da economia do território com mercados dinâmicos com vistas a promover a competitividade e o desenvolvimento dos agentes econômicos do território. A transformação institucional objetiva a aproximação e inclusão da diversidade de atores locais e entre eles e os agentes externos para promover consensos e a pactuação das regras que guiarão o desenvolvimento do território.

Do ponto de vista instrumental-operacional, um atributo importante a ser ressaltado dos territórios, é que eles não são construções objetivas e delimitados na realidade, como são as divisões político-administrativas dos municípios e estados. São resultado das próprias relações construídas entre os agentes do território que estabelecem padrões de comportamentos e de regras que são apropriados pelos gestores públicos e privados para facilitar o encadeamento das políticas e estratégias direcionadas ao conjunto de elementos que estão inseridos no território.

\footnotetext{
"Puesto de otra forma, el território en cada proceso de desarrollo rural es una construcción social, y no un espacio "objetivamente existente" y delimitable mediante un puro ejercicio técnico ex ante, en virtud de una u otra variable o conjunto de variables físicas o económicas. La definición operacional de territorio es puramente instrumental, es decir, funcional a los objetivos y alcances del proyecto que se proponen los agentes de los procesos de desarrollo territorial rural." (SCHEJMAN BERDEGUÉ, 2004, p. 33).
}

Schneider, Mattei e Cazella (2004, p. 102) sugerem que "o território emerge como nova unidade de referência para a atuação do Estado e a regulação das políticas públicas.” O olhar das políticas por meio da estratégia territorial envolve, também, o desenvolvimento do 
capital social dos territórios. Nesse sentido, além de trabalhar o desenvolvimento das atividades agrícolas e não-agrícolas com potencial de estimular mudanças no território, esse enfoque visa estimular o desenvolvimento das relações entre os atores dentro do território e deles com os atores externos por meio fortalecimento das relações sociais e da pactuação de regras que conduzem o comportamento dos atores territoriais no sentido de atuarem para a promoção de mudanças no território.

Essas relações envolvem normas de comportamento e padrões culturais que compõem as instituições que são próprias do território e que são valorizadas nessa nova estratégia de desenvolvimento rural. Sobre a origem dessas normas Durston (2000, p. 10) afirma que: "son parte de, y serían especificas a ciertas culturas y se transmiten de generación en generación, principalmente a través de la socialización temprana al interior de la familia.".

O desenvolvimento dessas instituições tem o potencial de estimular ganhos de capital social para o território, aumentando suas chances de terem dinâmicas mais férteis que tragam melhores resultados econômicos e sociais para os atores e o território envolvidos no processo.

Neste sentido, Abramovay (2000b, p. 13) ressalta a importância da transformação institucional, que remete ao capital social, e que faz parte da estratégia territorial de desenvolvimento:

"Construir novas instituições propícias ao desenvolvimento rural consiste, antes de tudo em fortalecer o capital social dos territórios, muito mais do que em promover o crescimento desta ou daquela atividade econômica."

A ideia por trás da abordagem territorial do desenvolvimento rural, tanto em termos de superação da pobreza quanto do desenvolvimento do próprio território, consiste em alavancar um processo movido por suas forças endógenas, envolvendo os atores sociais, econômicos e institucionais sob novas instituições criadas para o fim de fazer convergir esses esforços em torno de um projeto para o território. Visto de outra forma, o movimento de desenvolvimento do território a partir da interação de seus atores e potencialidades aponta para superação da dependência de estímulos oriundos do Estado o que consolida um processo mais autônomo de crescimento.

O destino dos territórios deixa de se concentrar numa autoridade ou numa agência central encarregada de distribuir recursos e passa a depender da capacidade de criação de riquezas que a própria interação entre os atores locais é capaz de criar (BEDUSCHI FILHO; ABRAMOVAY, 2004, p. 44). 


\subsection{A formação da agenda das políticas publicas de Desenvolvimento Territorial}

A década de 1990 foi importante para uma profunda releitura nas formas sociais de produção do meio rural com a noção da agricultura familiar como categoria analítica, bem como a absorção deste conceito pelos movimentos sociais. Na outra mão, temos as diversas experiências internacionais em relação à construção da abordagem dos territórios que os países da América Latina.

Neste sentido, em vistas às experiências brasileiras, são notórias as evidências de diversos caminhos percorridos para adoção da abordagem territorial do desenvolvimento rural na agenda de governo. Adotaremos o modelo de formação de agenda governamental proposto por Kingdon (2006). Uma agenda governamental é uma lista de situações ou problemas que chama a atenção por parte das autoridades governamentais e tomadores de decisão em um dado momento (KINGDON, 2006). Para um determinado tema ser elevado ao status de problema e entrar na agenda governamental é necessária a convergência de três fluxos decisórios independentes:

Fluxo dos problemas (problems streams): é o fluxo nas quais determinadas questões ou temas ganham relevância ao ponto de serem agrupados num problema a ser trabalhado pelos tomadores de decisão na agenda governamental. A transformação de um tema em um problema de agenda pode ser influenciada por: i) dados ou indicadores; ii) eventos de grandes magnitudes (desastres ecológicos, crise econômica iii) e, feedback sobre programas em andamento no governo;

Fluxo das soluções ou alternativas (policy streams): é o fluxo do conjunto de propostas para tratamento dos problemas, as quais foram elaboradas pelo conjunto de especialistas (policy communities), incluindo pesquisadores, consultores, burocratas de carreira, gestores, entre outros. Essas ideias permanecem num "caldo primitivo de políticas" (policy primeval soup), onde será conflitada, num processo de embate e seleção daquelas mais aceitas;

Fluxo político (politics stream): é o fluxo dos conflitos e negociação política em torno da promoção ou não de uma determinada ideia para a agenda governamental. Neste ponto três elementos podem influenciar decisivamente: i) clima ou humor nacional; ii) forças políticas organizadas de movimentos sociais, grupos de interesses, opinião pública, entre outros; iii) e, mudanças na estrutura do governo (turnover), Congresso Nacional e empresas públicas. 
A possibilidade de convergência entre os três fluxos é chamada de janela de oportunidade. Este raro momento de convergência é influenciado principalmente pelo fluxo dos problemas e o fluxo político. Assim, a oportunidade de mudança surge a partir do momento que um determinado tema chama a atenção dos tomadores de decisão governamentais, ou quando há uma mudança nas estruturas do próprio governo. Já as soluções não exercem influência direta na mudança de agenda, permanecendo ou até mesmo sendo excluído do caldo primitivo das políticas. O fluxo das soluções só se torna importante quando condicionado à mudança nos dois primeiros fluxos (CAPELLA, 2006). Por fim, a mudança na agenda só ocorre quando há a convergência dos três fluxos (problemas, soluções e política). $\mathrm{O}$ encontro dos três fluxos é denominado coupling, onde o mesmo só ocorre no momento em que se abre a janela de oportunidade (CAPELLA, 2006).

Perante esta breve exposição do modelo de formulação da agenda, podemos estabelecer de forma mais clara como a abordagem territorial do desenvolvimento rural se tornou um problema a ser alvo de políticas no âmbito do governo federal. O início da década de 1990 foi marcado pela crise financeira internacional, por um lado, e, por outro lado, pelas evidências de aprofundamento das desigualdades sociais, principalmente no período da ditadura civil-militar, e que ganharam notoriedade a partir do período de redemocratização. Nas áreas rurais, esse quadro era ainda mais alarmante devido à falta de acesso a bens e serviços públicos pelas populações que habitavam este espaço (COMISSÃO CAMPONESA DA VERDADE, 2014).

Neste contexto, revela-se a importância dos movimentos sociais, assim como da comunidade acadêmica, pois se os primeiros foram fundamentais em refletir a realidade dos territórios, seja pelas manifestações pela reforma agrária, seja pela participação em arenas públicas voltadas ao desenvolvimento regional, a segunda o foi pelos estudos realizados que contribuíram para emergência de nova categoria social, a agricultura familiar (SCHNEIDER, 2010).

Relacionado a este momento, temos a emergência do debate em torno da abordagem territorial realizada no âmbito da academia e dos organismos multilaterais à luz das recentes experiências ocorridas na Europa. São esses os "atores invisíveis", na expressão de Kingdon, que fazem emergir a abordagem territorial como uma proposta de resolução para a redução da pobreza e dinamização das áreas rurais mais deprimidas (SCHNEIDER, 2010).

Sendo este um momento de reformulação de ação do Estado, relacionada, principalmente, à redução do grau de atuação da esfera federal, surgiram diversas experiências de planejamento e cooperação supra municipal, como os consórcios 
intermunicipais, cujos municípios se articulavam na organização dos recursos técnicos e humanos para atuar nas áreas mais deprimidas de seus territórios (CALDAS, 2007; SCHNEIDER, 2010).

Os parágrafos acima reforçam a importância dos arranjos institucionais intermediários de atuação, os quais devem ir além dos municípios, mas ficar aquém dos estados, ganharam cada vez mais força nos meios acadêmicos (BEDUSCHI; ABRAMOVAY, 2003). Este fato está relacionado com "clima de euforia" relacionado ao crescimento de mecanismos de participação popular e de movimentos sociais que vinham tornando esses instrumentos como fóruns legítimos de debate.

Se o contexto aponta para a emergência da situação da pobreza do campo como um problema a ser enfrentado pela gestão pública, por um lado, e a crescente geração de dados e busca por outras experiências de gestão territorial, por outro, podemos considerar, assim, a emergência do fluxo dos temas a serem elevados a categoria de problema, bem como o fluxo das soluções e alternativas em torno destes temas.

Sobre o fluxo político, observamos uma retomada crescente da influência estatal no meio rural, principalmente com a implementação de políticas voltadas a redução da pobreza extrema. Temos em primeiro lugar, a já mencionada aposentadoria rural em 1991. Em resposta às reivindicações dos movimentos sociais, o governo Itamar Franco (1992-1994) promulga a Lei de Agrária e do Rito Sumário em 1993. Esta política pavimentou caminho para o governo Fernando Henrique Cardoso (1995-1998) realizar ações fundiárias até então inéditas. O grande impacto desta legislação impulsionaria a criação da Secretaria Extraordinária de Assuntos Fundiários (SEAF). Com esta secretaria foi estabelecida a base institucional para a posterior criação do Ministério do Desenvolvimento Agrário (MDA) em 1998 (SCHNEIDER, 2010).

Ademais, os mecanismos de participação foram ampliados em torno das políticas de promoção de segurança alimentar e do desenvolvimento local. Em 1993 o governo Itamar Franco institui o Conselho Nacional de Segurança Alimentar e Nutricional (CONSEA). No campo das pesquisas, a elaboração do Mapa da Fome no mesmo ano pelo Instituto de Pesquisa Econômica Aplicada - IPEA e a realização da I Conferência Nacional de Segurança alimentar estruturaram o debate sobre a necessidade de um plano a nível nacional de combate a fome e a miséria (CUSTÓDIO, 2009; KARAM, 2012).

No entanto, o Governo FHC interrompe a construção da política de segurança alimentar com a extinção do CONSEA em 1995 em substituição ao Programa Comunidade Solidária (PCS). O forte caráter assistencialista do programa freou um debate mais amplo 
relacionado à questão da fome. O PCS foi substituído pelo Programa Comunidade Ativa (PCA) em 1999. Este programa objetivava a articulação local em torno do fórum de Desenvolvimento Local, Integrado e Sustentável - DLIS, para a formulação de um Plano Municipal de Desenvolvimento Local e Integrado, que, contudo, não atingiu seus objetivos estabelecidos por falta de apoio do mesmo governo que o criou (PRADO, 2011; KARAM, 2012).

As principais críticas relacionadas a estas políticas residem na sua focalização e a sua atuação estritamente localizada, sendo realizadas em caráter emergencial e planejamento estratégico de longo prazo. Segundo alguns críticos (DUARTE, 2000, KARAM, 2012) as ações localizadas mantinham relações de clientelismo entre os atores mais influentes e o poder público. A agenda voltada para a redução das assimetrias sociais e da promoção do desenvolvimento territorial terminou por entrar em conflito com a agenda de reequilíbrio da economia que ocorreu durante toda a década de 1990. Não havia recursos disponíveis para a efetivação de um agenda que trabalhasse a abordagem territorial do desenvolvimento rural.

Deste modo, o fluxo da política que irá convergir para a entrada da abordagem territorial na agenda pública são as eleições realizadas para presidente da república em 2001. A agenda montada pelo então candidato Luiz Inácio Lula da Silva e sua equipe pautava-se pela redução da extrema pobreza e inclusão social e econômica das regiões mais deprimidas. Tal agenda foi amplamente permeável às propostas que até então se encontravam no "caldo primitivo de políticas", propostas estas mantidas e reforçadas pela "comunidade política" e os seus "atores invisíveis", ou seja, os acadêmicos e consultores dos organismos multilaterais.

Logo, a entrada de Lula no cargo de Chefe Executivo da União atua na ativação de três variáveis do modelo de formação de agendas do Kingdon: i) primeiramente, temos a mudança de governo (turnover) que possui uma agenda voltada em sua maior parte à resolução da pobreza e do desenvolvimento das regiões com maior vulnerabilidade socioeconômica; ii) é neste raro momento no qual há convergência da agenda do governo com as reivindicações dos movimentos sociais do campo e a necessidade da abordagem territorial do desenvolvimento rural defendida por cientistas e organismos multilaterais e, iii) a confluência dos fluxos resulta na abertura da janela de oportunidade, ou seja, o raro momento no qual o tema alcança status de problema que fara parte das prioridades governo.

Esquematicamente, podemos representar o modelo de Kingdon da seguinte forma: 


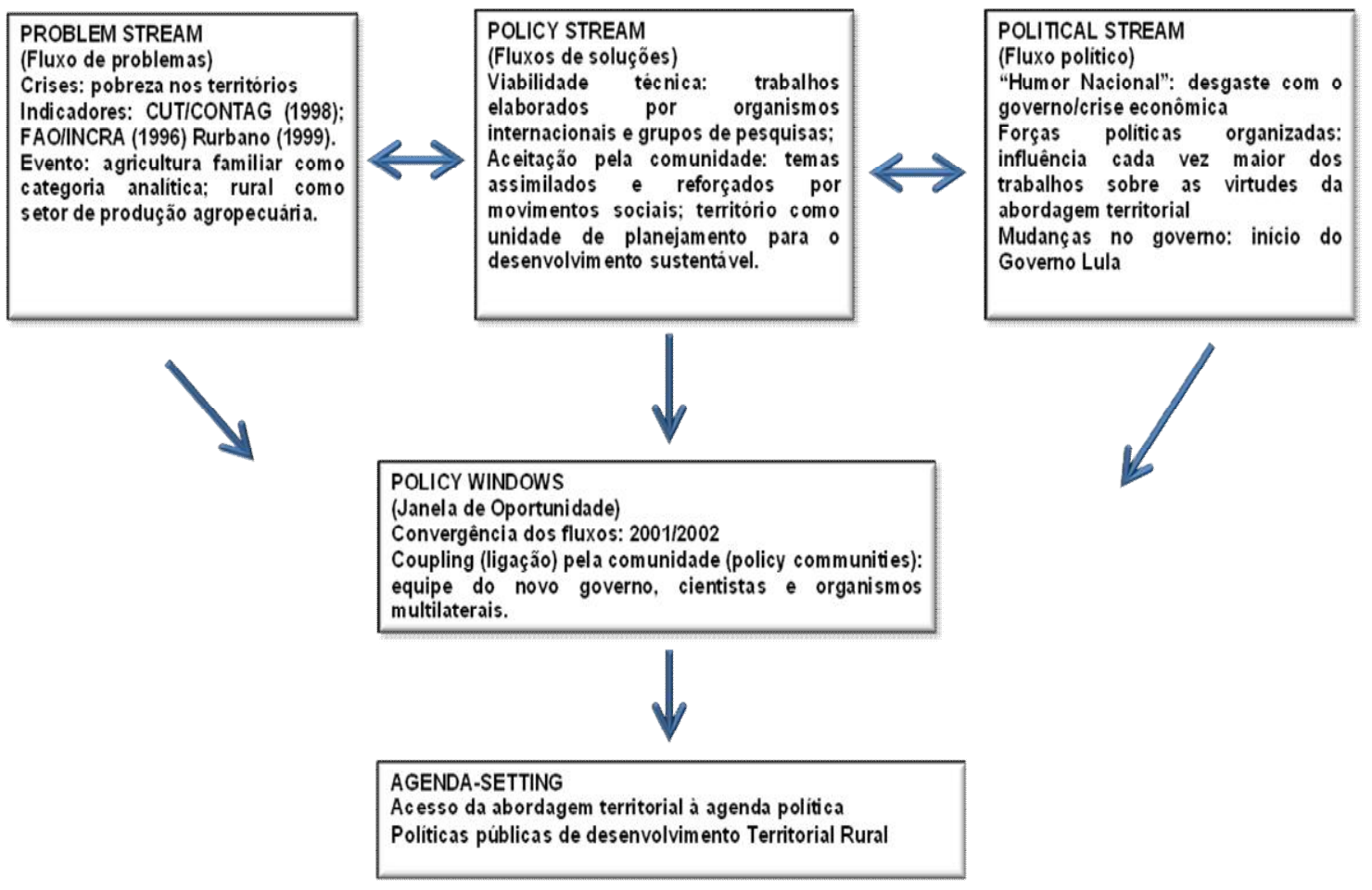

Figura 2.1. Modelo de múltiplos fluxos da abordagem territorial. Fonte: Capella (2006) e Kingdon, (2006). Adaptado pelo autor.

Traçado esse quadro de evolução e adoção da abordagem territorial do desenvolvimento rural, temos mais claros quais foram os caminhos que consolidaram o tema na agenda governamental. Tal abordagem teve relevante impacto na proposição e execução de políticas públicas no meio rural. 


\section{CAPÍTULO 3 - POLÍTICAS PÚBLICAS: BREVES CONSIDERAÇÕES}

A análise das políticas públicas passa a ser reconhecida como subcampo autônomo na Ciência Política nos Estados Unidos e na Europa no início do século XX. Enquanto os estudos norte americano colocavam atenção na produção e ação dos governos, os estudos realizados na Europa se ramificavam das abordagens teóricas relacionadas ao Estado e suas instituições (SOUZA, 2006).

Num primeiro momento, os estudos das políticas públicas assumiram os pressupostos que aquilo que o governo faz ou deixa de fazer consiste em objeto de formulação científica e pode ser analisado por pesquisadores independentes. Assim, as políticas públicas abrem um terceiro grande caminho na Ciência Política norte-americana no que se refere ao estudo do universo público: i) por um lado, havia a tradição dos céticos da natureza humana, os quais focalizavam o estudo das instituições como fator fundamental à regulação da sociedade; ii) por outro lado, havia a tradição dos que apostavam nas organizações locais e na virtude cívica como promotores do que seria considerado um "bom" governo e, iii) o "caminho do meio" surge no sentido de compreender como e por que os governos optam por determinadas ações. (SOUZA, 2006: 22).

O conceito de política pública pode ser definido como o fluxo de decisões públicas, objetivando a manutenção do equilíbrio social ou a introduzir desequilíbrios destinados à alteração de uma dada realidade. As decisões são condicionadas pelo próprio fluxo e pelas reações e modificações que elas provocam no tecido social ${ }^{7}$ (SARAIVA, 2006). Dito de outra forma, a política pública é a decisão por parte do governo do que será feito e do que não será feito. Este "governo em ação" tem o intuito de mediar os diversos conflitos buscando a construção do bem comum (SOUZA, 2006).

Os estudos sobre políticas públicas buscam a compreensão da inter-relação entre as instituições políticas, o processo político e os conteúdos da política. Esses modelos se contrapunham as análises anteriores que abordavam somente os conteúdos da política (policy) (FREY, 2000). Logo, as políticas públicas como arcabouço analítico são definidas por Souza como (2006, p. 26):

"o campo do conhecimento que busca, ao mesmo tempo "colocar o governo em ação' e/ou analisar essa ação (variável independente) e, quando necessário, propor mudanças no rumo ou no curso dessas ações (variável dependente). A formulação de políticas públicas constitui-se no estágio em que os governos democráticos traduzem

\footnotetext{
${ }^{7}$ Sabemos que a definição única de política pública restringe o amplo debate realizado pela Ciência Política em torno deste conceito. Porém, o debate conceitual fugiria dos objetivos desta pesquisa. A importância central é utilizar a literatura em torno das políticas públicas como uma abordagem metodológica de organização da literatura e de análise das políticas públicas em torno do Desenvolvimento Territorial Rural.
} 
seus propósitos e plataforma eleitorais em programas e ações que produzirão resultados ou mudanças no real".

A partir da contribuição de Frey (2000, p. 216) temos as seguintes dimensões de análise da política pública (polícy analysis):

I) dimensão institucional (polity) - é a ordem do sistema político constituída pelo sistema jurídico e pela estrutura institucional do sistema político-administrativo;

II) dimensão processual (politics) - é o processo político real na qual se materializa uma política pública. Geralmente é uma dimensão de caráter conflituoso no que diz respeito à imposição de objetivos, aos conteúdos e às decisões de distribuição;

III) dimensão material (policy) - é o conteúdo concreto de uma política pública, ou seja, a configuração dos programas políticos, aos problemas técnicos e ao conteúdo material das decisões políticas.

O modelo de análise das políticas públicas (policy analysis) possui o potencial analítico de superar uma abordagem isolada priorizando ou a dimensão institucional (polity) ou a dimensão político processual (politics), ao interagir a dimensão material de política (policy) com as dimensões institucionais e político-processuais (FREY, 2000). As dimensões em questão são importantes para a compreensão da forma como o Estado realiza a sua atuação num determinado território, posto que a estrutura institucional e a dimensão processual influenciam de forma decisiva no conteúdo das políticas públicas (policies) (BEDUSCHI, 2012; FREY, 2000; TODESCO, 2007).

É crescente o uso do neoinstitucionalismo como ferramental teórico e metodológico para compreender as políticas públicas. As correntes elaboradas em torno desta abordagem remetem à importância do surgimento de regras e costumes, bem como a sua influência no comportamento humano e as mudanças e adaptações que as instituições sofrem com esta influência ${ }^{8}$. Dito de outra forma, o neoinstitucionalismo aborda como as instituições são criadas e moldadas ao longo do tempo (FREY, 2000). Segundo Douglass North (1990: 3) "Instituições são as regras do jogo numa sociedade, ou mais formalmente, são os constrangimentos humanamente idealizados que moldam as interações humanas". As instituições são formadas pelo seu caráter formal, com suas leis, constituições e instituições públicas, e pelo caráter informal, com os significados compartilhados, práticas e identidades moldadas ao longo do tempo (FREY, 2000). A corrente neoinstitucionalista evidencia que a importância da tomada de decisão não se restringe somente a influência dos indivíduos e

\footnotetext{
${ }^{8}$ Às Leitoras e leitores interessados nas diferentes correntes do neoinstitucionalismo, ver Hall e Taylor (2003).
} 
grupos organizados. As decisões também são moldadas pelas regras formais e informais que regem as instituições (SOUZA, 2006).

Contudo, há uma peculiaridade na utilização desta abordagem quando direcionada ao contexto das democracias recentes como a brasileira. A baixa consolidação de instituições democráticas traz a necessidade de integrar a dimensão institucional com a dimensão dos processos políticos, já que estes últimos ganham mais relevância na análise de políticas públicas em democracias menos maduras. Em outras palavras, Frey (2000, p. 251) observa que:

\begin{abstract}
"Levando em conta a instabilidade e fluidez das estruturas institucionais e dos padrões político-administrativos de países em desenvolvimento, caracterizados por democracias do tipo "delegativo", como é o caso do Brasil, podemos concluir que nesses países, mais ainda do que em democracias consolidadas, a 'policy analysis' deve enfocar os fatores condicionantes das políticas públicas- polity' e politics' - dando ênfase na sua dimensão processual, a fim de poder fazer justiça à realidade empírica bastante complexa e em constante transformação".
\end{abstract}

Feita essas breves considerações sobre a análise das políticas públicas, podemos dar maior atenção aos modelos processuais da política pública, ou seja, para o modelo do ciclo da política pública (policy cycle) (FREY, 2000). Este modelo se encontra na dimensão da análise da política pública (policy analysis) ou do também chamado processo de políticas públicas (policy process). A tipologia dos ciclos vê na política pública um processo deliberativo formalizado por vários estágios, constituindo um processo dinâmico e promotor da interação nas tomadas de decisões (SOUZA, 2006).

Desta forma, esses estágios funcionam como uma subdivisão analítica, que permite uma melhor análise do ciclo de vida de uma dada política pública (FREY, 2000). Desde o seu surgimento, diversos são os estágios elaborados até então, contudo, sempre seguindo de uma maneira ou de outras três estágios principais: formulação, implementação e avaliação. Utilizando a classificação elaborada por FREY (2000, p. 226), definida pelos seguintes estágios:

- Percepção e definição dos problemas: área de ampla atuação dos “atores invisíveis", esta é a fase onde são percebidos quais serão os potenciais assuntos a emergirem na condição de problema. Este problema deverá ser suficientemente importante para que tenha condições de entrar em definitivo como uma questão política (policy issue) a ser incluso na agenda;

\footnotetext{
${ }^{9}$ Segundo O’Donnell (apud, FREY, 2000: 248) Democracias delegativas caracterizam-se pela fraqueza e reduzida densidade de suas instituições, nas quais a influência sobre as decisões políticas fica reservada a uma elite classista. A influência nos processos de decisão política e na implementação das políticas é normalmente exercida de forma direta e não de forma "agregada", intermediada por partidos e associações.
} 
- Estabelecimento da agenda (agenda setting): este é o momento de decisão no qual os atores políticos mais relevantes decidem se um determinado tema entrará ou não na agenda de governo. Nesta fase a atuação dos múltiplos fluxos e da janela de oportunidade (KINGDON, 20006) serão condicionantes-chave para a formação da agenda;

- Elaboração de programas e de decisão: esta é a fase que, após a inclusão do tema na agenda e a efetivação da mesma, estratégias são criadas em torno da escolha mais apropriada dentre as alternativas de ação.

- Implementação de políticas púbicas: é a fase de concretização das ações estipuladas na fase de formulação e elaboração das políticas públicas. Os processos de análise da implementação se diferem por um lado, na análise da qualidade material e técnica dos programas e projetos, e por outro, na análise que direciona os esforços na compreensão das estruturas político-administrativas e a atuação dos atores envolvidos. Quando se compara os objetivos formulados dos programas com os resultados alcançados, examina-se até que ponto a proposta formulada foi cumprida, e quais as causas de eventuais "déficits de implementação";

- Avaliação da política pública e a correção da ação (evaluation): é a fase de apreciação dos programas já implementados em relação a seus impactos efetivos. É a fase de questionamento relacionado aos déficits de impacto e os efeitos colaterais indesejados das políticas públicas e prever a execução de ações futuras. É o momento fundamental de reconstrução e adaptação contínua das estruturas e instrumentos da ação pública, caracterizando o importante fator da aprendizagem política.

Em síntese, podemos resumir o ciclo das políticas públicas da seguinte forma.

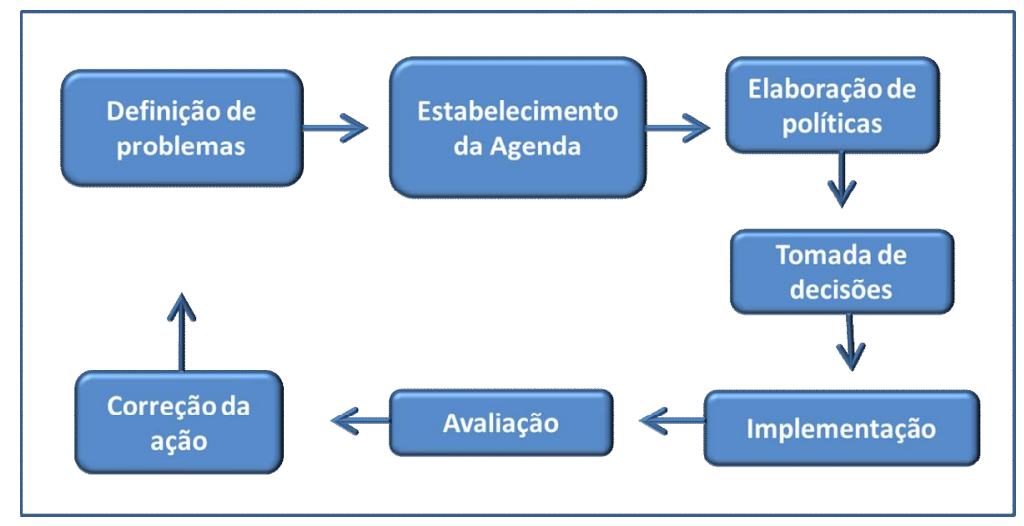

Figura 3.1.: Modelo ciclo da politica pública. Fonte: Frey, p. 226. Organizado pelo autor.

A abordagem dos ciclos foi alvo de diversas críticas devido ao seu caráter idealístico do processo político, que na prática, dificilmente se dá de pleno acordo com o modelo. 
Contudo, o quadro oferecido pelo ciclo das políticas públicas se traduz na sistematização e melhor compreensão dos processos políticos estudados, principalmente em relação aos seus déficits e gargalos (FREY, 2000).

Desta forma, daremos maior atenção a uma das etapas do ciclo de políticas O modelo de implementação da política pública. Esta abordagem surgiu com à necessidade de melhor compreensão dos limites e dificuldades que surgiam no processo de efetivar uma determinada política formulada. O modelo em questão pretendia esclarecer, os problemas - de ordem político-institucional, organizacional e ambiental - que emergiam durante a fase de execução, bem como os impactos das políticas implementadas (BARBOSA, 2014). Entende-se por implementação o processo de interação entre a proposição de objetivos e metas e as ações efetivadas para atingi-los. A implementação visa à elaboração de um planejamento e a organização do aparelho administrativo dos recursos humanos, financeiros, matérias e tecnológicos necessários para operacionalizar uma política (CARVALHO; BARBOSA; SOARES, 2010).

A noção de implementação foi se consolidando como um fator fundamental para compreender as condicionantes apropriadas à constituição e gestão de uma política pública. Ademais, este modelo evidencia um processo permeado por ampla autonomia e lógica própria de comportamentos e ações, características estas que definem de fato a execução de uma política publica (BARBOSA, 2014). Relembrando novamente o caráter heurístico destes modelos, os autores nos alertam sobre o componente do processo da política pública como um todo:

\footnotetext{
“[...] A tendência tem sido tratar as políticas como entidades claras, indiscutidas, cuja implementação pode ser estudada separadamente. Isso tem gerado problemas metodológicos e também problemas acerca do grau em que as preocupações práticas da implementação podem envolver, explícita e implicitamente, uma identificação com as perspectivas de alguns atores a respeito do que deveria ocorrer. (HILL, 2006, p.62)"
}

Dentre a grande amplitude de modelos e abordagens dos estudos sobre implementação, nos limitamos às considerações das duas principais abordagens do modelo de implementação: a abordagem de "cima para baixo" (top down) e a abordagem "de baixo para cima" (bottom-up) (HILL, 2006).

A perspectiva "de cima para baixo" surgiu a partir do modelo de estágios da política, na qual a política pública é vista por uma linha de etapas guiadas por lógicas diferentes (LIMA; D’ASCENZI, 2013). A implementação, nesta perspectiva, é vista como o ato de execução de atividades por indivíduos públicos e privados com vistas à consecução de políticas previamente estipuladas por decisões políticas (HILL, 2006). Nesta perspectiva, a 
análise é centrada nas regras que estruturam as políticas e os seus gargalos. Isso levou a maior preocupação com a formulação da política e a importância dos tomadores de decisão em mitigar os elementos que comprometem o êxito da execução. Tais elementos decorreriam das mudanças ocorridas na política durante a sua operacionalização (LIMA; D’ASCENZI, 2013).

A abordagem "de cima para baixo" foi alvo de diversas críticas devido à ênfase exagerada na capacidade dos formuladores das políticas em estruturar uma implementação da qual se teria um suposto controle (WINTER, 2010) e na crença que a determinação precisa de responsabilidades administrativas serão traduzidas em resultados, aumentaria a probabilidade de êxito na implementação das políticas (LIMA; D’ASCENZI, 2013). A abordagem puramente normativa e voltada aos resultados não identificavam o ambiente complexo no qual as políticas públicas se materializam. A centralidade da análise nos formuladores da política negligenciava os diversos grupos de interesse atuantes durante a operacionalização da política (LIMA \& D’ASCENZI, 2013), além de não considerar a implementação como um processo contínuo de decisões e ações que promovem interação e aprendizagem entre os executores das políticas e os seus beneficiários (HILL, 2006).

Já a abordagem "de baixo pra cima" é centrada no plano real de implementação da política, ou seja, no ponto onde o setor público encontra os cidadãos e as empresas (WINTER, 2010). A ênfase recai na influência que os executores da linha de frente possuem no momento de execução da política. Esses atores atuam em contextos diversos daqueles dos tomadores de decisão das políticas e estão imersos em diferentes lógicas de interação social, além de incentivos e constrangimentos que lhes conformam as possibilidades de ação. Sendo assim, este modelo permite uma abordagem mais realista da implementação, em contraposição à visão estritamente normativa e linear (BARBOSA, 2014).

A consolidação da perspectiva na qual o agente executor reformula a política pública durante a sua implementação, surge o modelo da "burocracia do nível de rua" (street-level bureaucracy). Os burocratas ao nível da rua são os servidores públicos que interagem diretamente com os cidadãos no cumprimento de suas tarefas e tem grande discrição na execução do seu trabalho (MEYERS; VORSANGER, 2010).

A discricionariedade do burocrata assume papel central na análise deste modelo. A partir deste conceito, importantes estudos foram realizados em torno de temas como: o grau de controle dos tomadores de decisão nas ações dos burocratas em torno dos objetivos das políticas; a influência da estrutura e do controle organizacional sob quais os burocratas realizam seus trabalhos; a necessidade de moldar os objetivos das políticas a uma dada estrutura que nem sempre se mostra adequada ou, a influência dos interesses individuais, das 
experiências profissionais e valores pelos quais os trabalhadores constroem significados que refletem na execução da política (MEYERS; VORSANGER, 2010).

Assim, a discricionariedade esta ligada a fatores normativos, por exemplo: o tipo de influência da discrição na promoção ou não da governança democrática; o trato com os cidadãos alvo das políticas e, a as ações que permitem adaptar os objetivos dos planos as realidades locais e dos diferentes grupos de interesses, com o fim de se obter o êxito das políticas (MEYERS; VORSANGER, 2010).

Nos últimos anos de muita reflexão por parte dos autores sobre os modelos top down e bottom-up, percebia-se que os modelos tinham mais complementaridades do que rupturas. Os modelos perdiam valor explicativo ao ignorar uma porção da realidade da implementação de ambas as perspectivas. Desde então, os autores têm realizado um esforço na tentativa de criação de modelos alternativos que integrem as duas abordagens (WINTER, 2010).

Dentre os diversos modelos híbridos, os mapeamentos descendentes (foward mapping) e os mapeamentos ascendentes (backward mapping) formulado por Elmore (1985 apud WINTER, 2010). Este modelo pressupõe a necessidade dos formuladores de política em considerar quais são os instrumentos e os recursos disponíveis para a sua execução (mapeamento descendente) e como se encontram as estruturas de incentivos dos beneficiários e a capacidade dos burocratas em alterar o equilíbrio dos incentivos, visando afetar a situaçãoproblema do grupo-alvo (mapeamento ascendente) (WINTER, 2010).

Vale ressaltar que enquanto a abordagem de "cima para baixo" se mostra mais adequada ao estudo de implementação nas áreas de políticas dominadas por um marco regulatório específico, ou em que a situação esteja razoavelmente bem estruturada, a abordagem de "baixo para cima" se mostra como uma análise de situações em que várias políticas diferentes são direcionadas para um determinado problema e que estejam primordialmente interessados nas diversas dinâmicas locais (BARBOSA, 2014).

As abordagens descritas propõe a integração das dinâmicas entre os agentes e as estruturas institucionais como variáveis explicativas à promoção das politicas públicas. Já os modelos relacionados aos processos políticos contribuem com elementos que buscam organizar e evidenciar os reais impactos das políticas públicas, evidenciando assim os limites e adaptações que ocorrem durante a implantação da política pública, bem como o papel dos gestores em assimilar e moldar as ações à realidade.

Assim, organizamos uma síntese da abordagem descrita. 


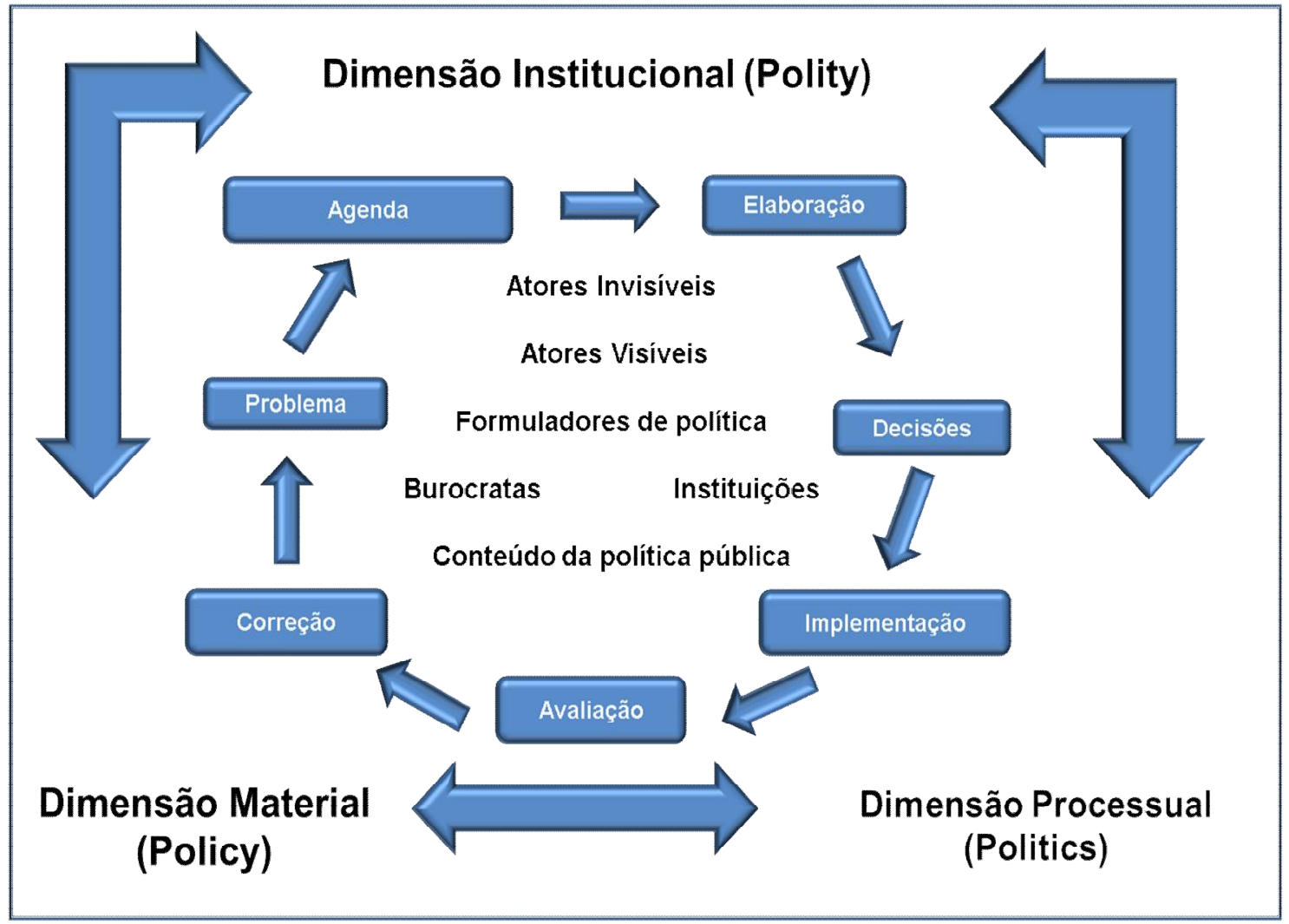

Figura 3.2: Síntese da análise. Elaborado pelo autor.

Esses modelos permitirão um olhar mais amplo nas análises da literatura de Desenvolvimento Territorial Rural, bem como podemos melhor compreender o processo de implementação das políticas com base nesta abordagem. 


\section{CAPÍTULO 4 - O MARCO TERRITORIAL NAS POLÍTICAS PÚBLICAS BRASILEIRAS}

\subsection{As primeiras experiências pelo Programa Nacional de Desenvolvimento Sustentável dos Territórios Rurais}

Os anos iniciais do século XXI marcaram a inclusão da abordagem territorial do desenvolvimento rural como uma estratégia inovadora para formular e implementar políticas públicas. A abordagem veio com o intuito de contrapor limitada visão setorial do campo, considerando as suas múltiplas dimensões. Essas múltiplas dimensões consideram não somente os potenciais dos arranjos produtivos diversificados e inovadores, mas como estes são construídos a partir do conhecimento compartilhado, gerando externalidades positivas voltadas a promoção de vantagens sociais, econômicas e culturais para o território.

A materialidade da abordagem territorial do desenvolvimento rural se deu com o início do governo de Luiz Inácio Lula da Silva à frente da Presidência da República (20032010). A grande expectativa criada por parte de diversos movimentos sociais e grupos de intelectuais se dava especialmente pela oportunidade de disseminar um novo modelo de governo. Os movimentos sindicais e diversos intelectuais participaram ativamente nas definições para uma nova política voltada ao meio rural (GUIMARÃES, 2013; SCHNEIDER, 2010).

Um dos primeiros movimentos do governo e sua equipe foi propor e executar a reestruturação do MDA. O debate em torno de se criar um planejamento a nível nacional voltado ao desenvolvimento das regiões rurais já havia iniciado no então extinto Conselho Nacional de Desenvolvimento Rural Sustentável - CNDRS - hoje o atual CONDRAF. Ademais, os governos anteriores promoveram importantes experiências, como o Fórum de Desenvolvimento Local Integrado e Sustentável e o Programa Comunidade Ativa (GUIMARÃES, 2013).

Desta forma, o MDA (2003, p. 34) define o território como:

\footnotetext{
“...um espaço físico, geograficamente definido, geralmente contínuo, compreendendo cidades e campos, caracterizado por critérios multidimensionais, tais como o ambiente, a economia, a sociedade, a cultura, a política e as instituições, e uma população, com grupos sociais relativamente distintos, que se relacionam in terna e externamente por meio de processos específicos, onde se pode distinguir um ou mais elementos que indicam identidade e coesão social, cultural e territorial".
}

Dentre as inovações da reestruturação do MDA, a implementação dos Territórios trouxe um novo marco institucional, devido à inclusão da perspectiva territorial como estratégia de cooperação interinstitucional, com ampla participação de organizações sociedade 
civil (KARAM, 2012). Ademais, o Colegiado de Desenvolvimento Territorial (CODETER) seria a instância privilegiada de gestão territorial (KARAM, 2012; RAMBO et al., 2013). Em 2004 foi criada a Secretaria de Desenvolvimento Territorial SDT (FREITAS; DIAS; FREITAS, 2010). A nova secretaria tinha a função de "desenvolver estratégias de integração de instrumento complementares à função produtiva, para que se estimule o dinamismo entre a base social, governos estaduais e municipais e a sociedade (MDA, 2003, p. 18).

Assim, as políticas públicas territoriais:

\begin{abstract}
"para serem efetivas, devem estimular a cooperação entre agentes públicos e privados, nacionais e locais, como elemento fundamental para a gestão das políticas, pois somente assim possibilita-se o controle social, incentiva-se o desenvolvimento de uma nova institucionalidade que concretiza o papel do capital social como um ativo, em um contexto de desenvolvimento sustentável e superação da pobreza." (MDA, 2003, p. 30).
\end{abstract}

A estrutura da SDT é dividia em duas coordenadorias: a coordenadoria de ações territoriais e a de órgãos colegiados de planejamento, assim como a coordenadoria em gerência de projetos (FREITAS; DIAS; FREITAS, 2010). No proposito de fortalecer a integração entre entes federados, foi criada a figura do consultor regional. Eles tinham justamente a função de articular ações interestaduais, além de sistematizar informações a partir das experiências territoriais (FREITAS; DIAS; FREITAS, 2010).

Há a presença de um consultor territorial a nível estadual, com o fím de acompanhar as ações nos territórios, incluindo o articulador territorial com o papel de operacionalizar a política como um devido burocrata de rua. Este último, geralmente é contratado por organizações atuantes no território articuladas com o MDA. O consultor territorial tem a função de apoiar e acompanhar a execução dos planos territoriais (FREITAS; DIAS; FREITAS, 2010).

Neste sentido, a SDT absorveria a estrutura e gestão do Programa Nacional de Desenvolvimento Sustentável dos Territórios Rurais - PRONAT - lançado em 2003. Este programa se originou do desmembramento das linhas do PRONAF, onde os eixos "Infraestrutura e Serviços Municipais" e "Capacitação dos Agricultores Familiares" foram transferidos para a SDT. A linha Crédito do PRONAF, a cargo da Secretaria de Agricultura Familiar, acabou reduzida ao crédito rural, enquanto o PRONAT criaria as linhas "Apoio a Projetos de Infraestrutura e Serviços em Territórios Rurais (Proinf)" e "Capacitação de Agentes de Desenvolvimento" (LEITE; WESZ Jr., 2012; SABOURIN, 2007).

O PRONAT surge com a intenção de promover dinâmicas locais de geração de renda a partir do apoio a organizações locais da agricultura familiar, bem como fortalecer os mecanismos de gestão compartilhada entre o poder público e sociedade civil fundamentado 
num arranjo institucional inovador. Desta forma, territorial arranjo territorial foi implementado em áreas mais deprimidas economicamente, com baixo IDH, com a maioria do público formada por populações rurais historicamente marginalizadas das políticas de desenvolvimento tais como agricultores familiares, assentados, quilombos e povos indígenas (CARVALHO, 2012). Assim, a abordagem territorial se consolida como uma estratégiachave para a promoção das políticas públicas para o meio rural:

\begin{abstract}
"Na abordagem territorial o foco das políticas é o território, pois ele combina a proximidade social, que favorece a solidariedade e a cooperação, com a diversidade de atores sociais, melhorando a articulação dos serviços públicos, organizando melhor o acesso ao mercado interno, chegando até ao compartilhamento de uma identidade cultural, que fornece uma sólida base para a coesão social e territorial, verdadeiros alicerces do capital social”. (MDA, 2003, p. 30).
\end{abstract}

O enfoque territorial que fundamentou o PRONAT objetiva a construção de um planejamento a nível territorial, visando o fortalecimento das potencialidades latentes do território para o surgimento de um círculo virtuoso de transformação socioambiental, produtiva e econômica nas regiões rurais mais deprimidas. Além da inovação normativa, o PRONAT materializa um processo de maturação do debate sobre agricultura familiar e a abordagem territorial cujos protagonistas surgiram dos extratos sociais, principalmente com raízes nas lutas agrárias e que se fortaleceu ao longo da década de 1990 (KARAM: 2012).

Entretanto, logo no início de sua implementação, as ações realizadas no âmbito do PRONAT se mostraram insuficientes. O diagnóstico evidenciava a necessidade de ampliação das opções de intervenção do PRONAT. Assim, em 2004 surge a linha "Elaboração de Planos Territoriais de Desenvolvimento Rural Sustentável”. Em 2006, com o objetivo de qualificação destes projetos, é lançada a linha "Gestão Administrativa do Programa" (LEITE; WESZ Jr., 2012). Outras linhas de apoio à organização produtiva foram implantadas, tais como "Fomento aos Empreendimentos Associativos e Cooperativos da Agricultura Familiar na Reforma Agrária”, em 2007, e o "Fortalecimento e Valorização de Iniciativas Territoriais de Manejo e Uso sustentável da Agrobiodiversidade” (LEITE; WESZ Jr., 2012).

Leite e Wesz Jr.(2012) reconhecem que a implementação do PRONAT representou uma grande inovação no cenário brasileiro, justamente pela tentativa de orientar os recursos voltados ao desenvolvimento para áreas objetivas com a proposta de ações inovadoras no âmbito das políticas públicas. Houve um significativo aumento de repasses de verbas destinadas a operacionalizar as linhas do PRONAT, o que em tese levaria a promover a redução da pobreza aliado à dinamização econômica das áreas rurais.

Porém, os autores criticam a ausência de um amparo legal dos territórios propostos pelo programa. Para os autores, este é um dos problemas-chave das ineficientes articulações 
entre prefeituras e órgãos do governo estadual (LEITE; WESZ Jr, 2012). Na verdade, a implementação dos territórios inibiu a atuação dos CMDRs, principal local de atuação de prefeitos e agentes de governos estaduais. A criação de uma instância acima do município e os recursos lá alocados não foram interessantes para as instâncias locais. Segundo Guimarães (2013, p. 212):

\begin{abstract}
"Mas a escala territorial não dispõe de uma representação política formalmente constituída e não existem disputas fora dos períodos eleitorais. Os políticos não se interessam por recursos decididos por coletivos, pois os esforços e desgaste são grandes e os recursos nem tanto. Por isso os políticos pragmáticos preferem resolver a destinação de recursos, quase sempre maiores dos que os disponibilizados pelo PRONAT, usando as velhas e boas ferramentas de apoio político nas eleições, quando os prefeitos indicam os candidatos que apoiam no estado e no nível nacional, recebendo recursos na sequencia, para os projetos de interesse do município e região. Por isso as eleições nacionais não coincidem com as municipais, pois cada um ajuda o outro a cada dois anos. Caso coincidissem, se formaria um vácuo de alianças para apoio mútuo entre as eleições, o que poderia resultar em descontrole da base de eleitores controlada por cada nível da esfera política."
\end{abstract}

O período eleitoral realizado a cada dois anos também impede a implementação das políticas territoriais, a agenda eleitoral compete com a agenda de governo e os períodos eleitorais ocorrendo em curtos períodos num amplo campo de disputa de poder, acaba por deixar a agenda de governo à margem das tomadas de decisões (CALDAS; MOREIRA, 2013).

Outro problema mencionado está relacionado às remessas orçamentárias referentes ao PRONAT, que são definidos por emendas parlamentares. Apesar do relevante aumento de verbas (LEITE; WESZ Jr., 2012), o fato da maior parte do orçamento advir de emendas, deslegitima o processo territorial. Enquanto os recursos do PROINF são mobilizados somente mediante a elaboração de projetos e avaliação dos mesmos pelo MDA e pelo CONDRAF, com as emendas esse processo é facilitado, ou mesmo dispensado (MONTENEGRO GÓMES; FAVARO, 2012).

Para Favareto (2010b), um dos gargalos de ação do PRONAT foi justamente o distanciamento entre as linhas de investimento e custeio da linha de crédito do PRONAF. Esse distanciamento minou as formas de cooperação e complementaridade entre os diferentes programas e secretarias na esfera federal. Leite e Wesz Jr. (2012) observaram que o aumento dos recursos voltados às linhas de financiamento ocorriam de forma concomitante à redução de verbas para a linha investimento, esta controlada em sua maior parte pelas prefeituras. Já as linhas de custeio eram absorvidas em sua maior por ONGs.

Com a implementação do programa surgiram gargalos como "inadimplência dos proponentes, baixa qualidade técnica dos projetos, falta de documentação e interesse dos políticos". Apesar deste quadro geral, os resultados mostram também que as linhas referentes 
ao custeio, por terem proponentes de entes não federados e pela maior flexibilidade administrativa, apresentam melhor uso do orçamento destinado (LEITE \& WESZ Jr., 2012: p. $653)$.

O outro desafio passaria pela criação de mecanismos que realmente sejam permeáveis às necessidades concretas das regiões mais pobres, reconhecendo e criando incentivos que valorizem os reais potenciais locais, orientado ao Desenvolvimento Territorial Rural. Esses desafios passariam necessariamente pelos seguintes critérios: i) complementaridade dos recursos públicos de diferentes ministérios e das diferentes esferas de governo, incluindo atores e entidades privadas; ii) subsidiariedade, ou seja, distinguir quais são os recursos passíveis de investimento para cada esfera de governo no intuito de criar mecanismos de enforcement segundo a competência das esferas de poder, e iii) o estabelecimento da devida contratualidade em torno de objetivos, metas e responsabilidades direcionadas a melhor alocação dos recursos, monitoramento das ações e avaliação dos resultados (FAVARETO; SCHRORDER, 2007).

Em que pese às críticas ao PRONAT, há o reconhecimento relacionado ao aumento substantivo de verbas que promoveu a mobilidade social de parte dos agricultores familiares (FREITAS; DIAS; FREITAS, 2010; GUIMARÃES, 2013; LEITE \& WESZ Jr., 2012). Os colegiados se tornaram espaços privilegiados da diversidade sociedade civil, técnicos e acadêmicos, promovendo trocas de experiências e aprendizado por meio da interação (BEDUSCHI, 2007; GUIMARÃES, 2013). Outra inovação importante está relacionada à criação de três sistemas de informações: o Sistema de Gestão Estratégica, o Sistema de Informações territoriais e o Sistema de Informações Gerenciais. Esses sistemas foram construídos com a intenção de facilitar o acesso aos resultados, permitindo ações de monitoramento, avaliação e pesquisas relacionadas ao PRONAT (GUIMARÃES, $2013^{10}$ ).

Segundo evidências obtidas por Guimarães (2013), as expectativas em torno do PRONAT seriam melhores alocadas no horizonte de planejamento à médio prazo e longo prazo, com etapas diferenciadas de intervenção por parte do estado e fornecendo apoio específico a múltipla realidade de agricultores familiares.

Das evidências de erros e acertos do PRONAT, foram elaboradas duas considerações importantes sobre os impactos do programa: i) não houve convergência entre a proposta de inversão pública direcionada aos agricultores de menor renda e estrutura. Ao contrário, a maior parte dos recursos no período onde o PRONAT se fez atuante, marcou-se pela

\footnotetext{
${ }^{10}$ Disponível em: $<$ http://sit.mda.gov.br/territorio.php?menu=territorio\&base=1\&informe=s\#>. Acesso em 17 jan. 2015.
} 
concentração de verbas repassadas aos agricultores mais organizados e capacitados, principalmente que estavam localizadas na Região Sul (ABRAMOVAY, 2002; SABOURIN, 2007); ii) o PRONAT concentrou suas ações nos agricultores familiares, consolidando o viés setorial da política(FAVARETO, 2009; SACCO DO ANJOS et al, 2010; LEITE \& WESZ Jr., 2012).

Mas tal discussão não estava somente sob os pilares da academia. O governo federal já havia percebido os limites de um programa desenhado estritamente para a agricultura familiar, desconsiderando a diversidade de atores e das realidades do meio rural brasileiro. Ademais, percebe-se que houve uma perda de importância em relação à agenda governamental construída em torno do PRONAT. Mesmo havendo uma substantiva melhora no aporte de recursos previstos nos Planos Plurianuais, de R \$292 milhões no período 20042007 para R\$ 1,523 bilhões no período 2008-2011 (KARAM, 2012: 117), o programa foi perdendo a sua importância dentro dos quadros do governo, por causa do baixo impacto de marketing político do mesmo (GUIMARÃES, 2013). Segundo Guimarães (2013: 218):

\footnotetext{
"Atualmente o PRONAT ainda não retomou o ritmo de atividades do final do governo anterior. Noticias da imprensa do Sul do país informam que recursos do orçamento do PRONAT estão sendo aplicados no fortalecimento das ações de governo e não em projetos aprovados pelos colegiados territoriais e em atividades de interesse dos territórios".
}

No bojo deste debate, governo federal lança em 2008 o Programa Territórios da Cidadania - PTC. O seu caráter inovador provocou diversas reações na comunidade política e acadêmica principalmente, devido à corajosa ideia da integração interministerial (GUIMARÃES, 2013).

\subsection{O Programa Territórios da Cidadania e a aposta na transversalidade da política pública}

O fluxo de debates organizados por universidades, institutos de pesquisa e organismos internacionais forneceram elementos atualizados sobre as condições das políticas disseminadoras da abordagem territorial no Brasil. No caso do PRONAT, o expressivo aumento de verba para o MDA a partir de 2003 diversificou as linhas de financiamento, permitindo aumentar o número de recursos humanos e à construção de parcerias com entidades atuantes no campo.

Este momento possibilitou a estruturação de colegiados territoriais com vistas a operacionalizar as políticas públicas de forma concertada com a sociedade civil e entidades 
privadas. É na concertação entre diferentes agentes que criam situações de embates, alianças, e soluções resultantes de intenso aprendizado social e institucional (CALDAS; MOREIRA, 2013). Os limites diagnosticados se relacionavam de forma mais expressiva à resistência do viés setorial promovida pela política dos Territórios Rurais. O PRONAT ficou restrito ao setor da agricultura familiar. Apesar da relevante valorização dos agricultores familiares, as políticas territoriais não tinham capacidade de abranger a crescente diversidade de atores sociais emergentes no campo. Havia a preocupação do governo federal em expandir a toda população pobre rural um leque mais amplo de políticas públicas para além do escopo estritamente agrário. Tal expansão também tinha a intenção de redistribuir as linhas do PRONAF, ora concentradas na região Sul (GUANZIROLI, 2007; GUIMARÃES, 2013).

É em meio ao dinâmico fluxo de informações e experiências que estimula o governo a dar materialidade às recomendações e críticas lançando em 25 de fevereiro de 2008 o Programa Territórios da Cidadania (PTC). O PTC surgiu por dois motivos: i) como uma resposta as constantes críticas por parte dos agentes públicos e estudiosos que não viam nos programas executados anteriormente a consolidação do arranjo institucional além do aspecto puramente normativo (FAVARETO, 2010a); ii) havia a necessidade do governo em lançar um programa de grande impacto, em complementação ao Lançamento do Programa de Aceleração do crescimento - PAC, programa este com o objetivo de impulsionar as obras de infraestrutura no Brasil (FAVARETO, 2009; GUIMARAES, 2013).

A abordagem do programa ganhou destaque dentro das políticas públicas executadas pelo governo. Esta estratégia significou o fortalecimento das ações sociais compensatórias através de uma perspectiva integral em todas as dimensões do desenvolvimento. Ademais, o PTC absorveria a importante estrutura deixada pelo PRONAT, caracterizando a continuidade das políticas públicas promovidas com este enfoque iniciados na década de 1990. Em 2008 o Programa Territórios da Cidadania foi instituído com a implantação de 60 territórios. Em 2009 foram envolvidos mais 60 territórios. Em 2010, finalmente, haveriam 169 territórios, sendo que a partir deste ano não houve a criação de novos territórios. (GUIMARÃES, 2013).

Segundo o relatório de lançamento do programa os "Territórios da Cidadania é uma estratégia de desenvolvimento regional sustentável e garantias de direitos sociais voltados às regiões do país que mais precisam, com objetivo de levar o desenvolvimento econômico e universalizar os programas básico de cidadania”. (BRASIL, 2008). Diferente dos programas anteriores, o PTC está relacionado a metas de superação da pobreza através da estruturação de ações diferenciadas direcionadas às regiões mais vulneráveis. (ECHEVERRI, 2010). 
O programa em questão tinha o objetivo de superar alguns desafios deixados pelas políticas antecessoras. Em primeiro lugar, o PTC foi a primeira politica pública com destaque para o combate à pobreza aliado ao objetivo de alçar o Desenvolvimento Territorial. Em segundo lugar, o programa em questão mostra uma mudança de posicionamento do Estado como ator central na execução das políticas. Se antes o mesmo tinha o papel somente de apoiar mediante a alocação de recursos e a prestação de serviços, agora o Estado propõe intervir diretamente no combate à pobreza de forma conjunta a estratégia de promoção ao desenvolvimento. Em terceiro lugar, o programa surgiu com o propósito de integração entre as esferas de governo. Este novo posicionamento estatal motivou um importante incremento de verbas ao MDA e o aumento de delegados estaduais, na premissa de integrar os entes federados.

Ligado ao último ponto, o PTC pretendeu promover dois mecanismos de coordenação: i) o mecanismo de coordenação horizontal, ou seja, a articulação entre os diversos ministérios tanto no âmbito do planejamento como no âmbito da execução das diretrizes e políticas públicas e, ii) o mecanismo de coordenação vertical, ou, a coordenação entre as diferentes esferas de governo, sendo o território o local privilegiado de otimização de esforços e a emergência de sinergias, incluindo ai as entidades privadas com e sem fins lucrativos ${ }^{11}$.Em síntese, "os Territórios da Cidadania tem como objetivos promover desenvolvimento econômico e universalizar programas básicos de cidadania por meio de uma estratégia de desenvolvimento territorial sustentável ${ }^{12}$.

A consolidação da estratégia territorial levada a cabo pelo MDA foi um pilar fundamental na criação do PTC, pois culminou na corajosa proposta de implementar uma política púbica na ótica da transversalidade. O Programa envolveu os esforços de vinte e cinco órgãos e entidades federais: Ministério da Casa Civil/PR (MCC); Ministério do Planejamento, Orçamento e Gestão (MPOG); Ministério do Desenvolvimento Agrário (MDA); Ministério do Meio Ambiente (MMA); Ministério da Integração Nacional (MI); Ministério do Desenvolvimento Social e Combate à fome (MDS); Ministério de Minas e Energia (MME); Ministério da Saúde (MS); Ministério da Educação (ME); Ministério da Cultura (MinC); Ministério do Trabalho e Emprego (MTE); Ministério da Agricultura, Pecuária e Abastecimento (MAPA); Ministério das Cidades (MCidades); Ministério da

\footnotetext{
${ }^{11}$ Territórios da Cidadania: evolução ou revolução das políticas públicas no meio rural brasileiro? Disponível em:

$<$ http://cartamaior.com.br/?/Opiniao/Territorios-da-Cidadania-evolucao-ou-revolucao-das-politicas-publicas-nomeio-rural-brasileiro-/22509>. Acesso em: 16 jan. 2015.

12 Disponível em: <http://www.territoriosdacidadania.gov.br/dotlrn/clubs/territriosrurais/one-community>. Acesso em 17 jan 2015.
} 
Justiça (MJ); Ministério da Ciência e Tecnologia (MCT); Ministério das Comunicações (MC); Ministério da Fazenda (MF); Secretaria Geral da Presidência da República (SRI/PR); Secretaria Especial de Promoção da Igualdade Racial (SEPPIR/PR); Secretaria Especial de Aquicultura e Pesca (SEAP/PR); Secretaria Especial de Políticas para as Mulheres (SEPM/PR); Banco do Brasil; Banco da Amazônia; Caixa Econômica Federal; Banco do Nordeste do Brasil; e BNDS.

O arranjo interinstitucional, até então inédito ao nível dos ministérios sob o comando do MCC, está articulado verticalmente com a implantação de colegiados gestores nos três níveis de governo, visando à execução e gestão das ações previstas no programa. No plano federal aparece a figura do Comitê gestor Nacional com a função de orientar e monitorar a atuação dos comitês subnacionais, no que se refere à aplicação de recursos e à implementação da proposta interministerial. No plano estadual surge o Comitê Gestor Estadual, para acompanhar as ações do programa nos territórios com base nas diretrizes elaboradas pelo Comitê Gestor Nacional. Por fim, a nível local, o colegiado territorial terá a função recepcionar, articular e executar os projetos territoriais elaborados durante o PRONAT com a ampla participação do poder público, sociedade civil, ONGs e entidades privadas.

Ressalta-se que o PTC deu continuidade aos critérios utilizados na definição dos TRs: regiões com baixos indicadores de desenvolvimento humano; maior concentração de assentamentos da Reforma Agrária e agricultores familiares; maior número de beneficiários do Programa Bolsa Família; maior número de municípios com baixo dinamismo econômico, e maior organização social. Os territórios, por outro lado, tinham como características em comum a densidade populacional de até 80 habitantes por km2 e população média municipal de 50 mil habitantes. Os territórios já organizados em territórios rurais de identidade; integrados com os Consórcios de Segurança Alimentar e Desenvolvimento Local (CONSAD) e/ou Programa Mesorregiões (PROMESO), recepcionaram o programa, reforçando os preceitos territoriais estruturados pelo MDA (KARAM, 2012).

As ações propostas pelo PTC estão organizados em três eixos: apoio a atividades produtivas; cidadania e direitos; infraestrutura. Por sua vez, estes eixos se desmembram em sete temas: Organização Sustentável da Produção; Ações Fundiárias; Educação e Cultura; Direitos e Desenvolvimento Social; Saúde; Saneamento e acesso à Água; Apoio à Gestão Territorial; e, Infraestrutura.

Os eixos e temas orientam a elaboração anual da Matriz de Ações, ou, a organização programática das ações ofertadas pelo Governo com vistas a atender as demandas dos territórios. A partir da liberação da Matriz, tem o início do ciclo de gestão do programa. O 
ciclo de gestão se inicia com a elaboração da Matriz de Ações no âmbito federal, compartilhada e modificada pelos entes estaduais e municipais. A Matriz é então apresentada e no nível territorial onde as ações são adaptadas e priorizadas de acordo com as demandas do Território. Prossegue-se com a elaboração de um Plano Território de Ações Integradas (PTAI) que é resultado do refinamento das propostas elaboradas no nível federal, adaptadas pelos atores locais/regionais do Território nessa participação. Após o debate territorial, o Comitê Gestor Nacional detalha a Matriz Territorial, incorporando ajustes e complementações. O resultado é o Plano de Execução, base para o monitoramento e o controle social da realização das ações pactuadas no Território.

O próximo passo após apresentação do PTAI é a criação do Relatório de Execução, que vai servir de instrumento para os gestores do PTC acompanharem as ações que estão sendo implementadas. Este relatório detalha os estágios da execução física e orçamentáriafinanceira, as restrições, os riscos e as providências adotadas. É complementado com relatórios elaborados pelos gestores das ações que contêm dados do andamento das obras nos municípios, localidades e comunidades. Sinteticamente, podemos representar o ciclo na figura abaixo.

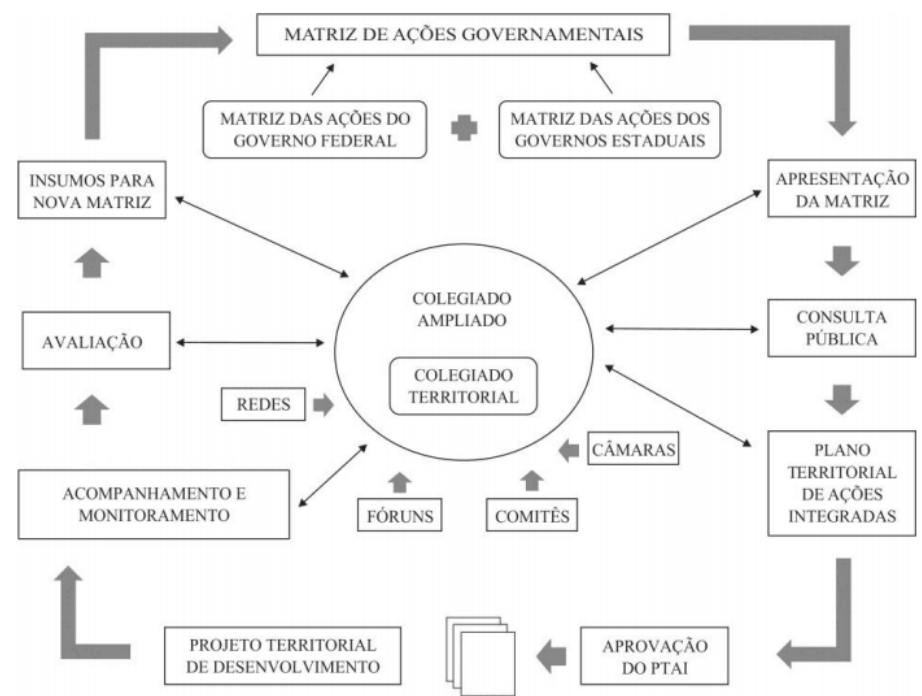

Figura 4.1. Ciclo de gestão do Programa Territórios da Cidadania Fonte: Guimarães (2013).

Esse ciclo representa a territorialização das ações formuladas a nível federal. Como sugere Leite e Wesz Jr. (2012: p. 653):

"Muito mais que a mera somatória de ações e dotações orçamentárias dos ministérios sobre um mesmo espaço social, trata-se de pensar a lógica da territorialização e governança de políticas a partir de um encontro de ações bottomup, pelos atores locais - agora não necessariamente agrários - com aquelas topdown, também não necessariamente setoriais.”. 
A implementação do PTC chegou ao seu maior grau de investimento em 2010, contabilizando 120 territórios, com uma lista de 169 ações e uma execução orçamentária de R\$ 19,7 bilhões (KARAM, 2012).

O quadro a seguir ilustra o alcance do PTC em relação ao seu público alvo em nível nacional.

Tabela 4.1 - Abrangência nacional do Programa Territórios da Cidadania

\begin{tabular}{lcc} 
Municípios & 1851 & $(33,27 \%$ do total do páis $)$ \\
Área & $4.527 .695,40$ & $(52,48 \%$ do total do país $)$ \\
População & 42.741 .272 & $(23,23 \%$ do total do país $)$ \\
População Rural & 13.128 .956 & $(46,19 \%$ do total do país $)$ \\
Pes cadores & 440.075 & $(55,11 \%$ do total do país $)$ \\
$\begin{array}{l}\text { Agricultores } \\
\text { Familiares } \\
\text { Famílias As s entadas }\end{array}$ & 2.041 .552 & $(46,79 \%$ do total do país $)$ \\
Demanda Social(*) & 587.234 & $(66,68 \%$ do total do país $)$ \\
Bols a Família & 2.628 .786 & $(50,13 \%$ do total do país $)$ \\
Quilombolas & 4.048 .303 & $(36,65 \%$ do total do país $)$ \\
Terras Indíge nas & 1.004 & $(66,49 \%$ do total do país $)$ \\
\hline Font & 349 & $(52,09 \%$ do total do país $)$ \\
\hline
\end{tabular}

Fonte: MDA, 2015.

Os números de alcance do PTC são relevantes e demonstram o impacto devido ao amplo leque de ações direcionadas ao território. Isto permitiu ações contínuas voltadas à redução da pobreza nas regiões mais deprimidas socioeconomicamente. Além disto, houve uma intensa mobilização por parte da sociedade civil para pressionar os gestores municipais a darem andamento nos projetos visando à obtenção de recursos antes nunca disponíveis (GUIMARÃES, 2013).

\subsubsection{Os Territórios da Cidadania à luz da literatura}

Quando voltamos nossos olhares para a literatura relacionada à análise das políticas territoriais, podemos avaliar de forma mais profunda os reais efeitos do PTC e dos programas 
de desenvolvimento territorial em geral. Assim, buscamos a síntese de alguns estudos realizados em diversos locais do Brasil. Temos assim o intuito de melhor nos situarmos sob quais fatores e condicionantes o PTC foram implementados a partir da ilustração de alguns estudos de casos, para depois tecermos considerações e críticas em relação ao programa em tela.

No caso do Território da Cidadania do Noroeste de Minas (TCNM), Tanure (2012) faz uma recuperação histórica dos condicionantes que levaram a região a ser um importante polo agrícola no Brasil. Para Tanure, este foi um fator chave pela boa aceitação dos programas territoriais, principalmente no seu início, cujos impactos positivos foram relevantes para a região reduzir o quadro de disparidade social. Contudo, o autor sinaliza que nos últimos anos, o PTC tem repassado mais verbas para crédito rural e transferência de renda em detrimento as verbas repassadas para investimentos, principalmente na saúde e educação. Entretanto, a concentração dos recursos às organizações de agricultores familiares restringe a efetivação da abordagem territorial.

Oliveira (2012) se debruçou sobre a implementação do PTDRS e do PTC nos Território da Cidadania Central (TCC) e no Território da Cidadania Madeira Mamoré (TCMM) no estado de Rondônia. A partir de uma abordagem dialética ${ }^{13}$, a pesquisa foi desenvolvida no sentido de observar qual era a permeabilidade dos programas federais de desenvolvimento territorial em relação a grande diversidade de organizações sociais que caracterizava os territórios em questão. Seus resultados demonstram que há uma intermitência na participação popular. Os mecanismos de participação eram em sua maioria dirigidos aos interesses dos gestores públicos e das prefeituras. Suas conclusões demonstram que as políticas de desenvolvimento territorial não alcançam a ampla diversidade das realidades brasileiras (OLIVEIRA, O. F., 2012).

A pesquisa realizada por Oliveira (2012) buscou entender a interpretação dos gestores públicos sobre o processo de implementação do Território da Cidadania Sertão de Minas (TCSM), utilizando a abordagem da dualidade da política pública ${ }^{14}$. A análise deste caso mostra que houve uma grande aceitação por parte tanto da sociedade como dos gestores

\footnotetext{
${ }^{13}$ Segundo Oliveira (2012, p. 12) "a abordagem dialética [...] parte de uma abordagem histórica - permitindo compreender os processos e mudanças ocorridos na sociedade e em suas instituições - e avança na reflexão sobre as relações existentes entre a implementação de políticas públicas e o território".

${ }^{14}$ Segundo Oliveira (2012, p. 101) “A unidade de análise ‘dualidade da política pública’ tem em vista permitir a incorporação na análise de políticas públicas, dos símbolos, valores, princípios e propriedades materiais. Essa perspectiva posiciona as pessoas como constituintes de estruturas específicas, caso seja recorrente o uso dos princípios e propriedades estruturais de uma política pública qualquer. De maneira que as estruturas de determinada política pública emergem conforme seu uso - e esse uso está recursivamente instanciado nas ações dos sujeitos individuais, logo orientados por valores, crenças objetivos, dentre outros".
} 
públicos incumbidos de articular a abordagem territorial. Contudo, a proposta participativa do controle dos recursos afastam entes do Estado e dos Municípios dos processos decisórios. A ausência da articulação vertical inibe a realização e projetos integrados e com maior otimização de recursos. Sendo assim, o autor recomenda que um maior esforço para a integração de políticas no âmbito federal chamariam maior atenção por parte dos Estados e Municípios (OLIVEIRA, L. C., 2012).

Outro estudo que mostra a diversidade das experiências territoriais ocorreu no Território da Cidadania Norte do Rio de Janeiro (TCNRJ). Kronemberger, Villela e Zani (2012) analisaram a influência dos Arranjos Produtivos Locais ${ }^{15}$ (APLs), que surgiram no território em questão devido à constituição de arranjos voltados a desenvolver a cadeia do Petróleo. Os resultados demonstram que houve uma distribuição desigual dos incentivos e royalites entre os municípios, refletindo no aumento de tensão entre os municípios que participavam da APL em detrimento dos municípios rurais. Os municípios ligados à cadeia do petróleo não mostram interesse em participar do colegiado do TCNRJ. Como recomendação, os autores mencionam que a participação mais incisiva dos atores sociais dos municípios no colegiado aumentariam as chances de equalizar a cisão entre os municípios "ricos" e municípios “pobres”.

A relação entre entes privados e as políticas públicas territoriais não são sinérgicas em boa parte dos casos, como demostra o estudo de Zani e Tenório (2012) no TCNRJ. Segundo os autores, se o marco normativo que direciona os programas territoriais incentiva o pluralismo de atores, na prática as políticas e recursos direcionados aos territórios respondem especificamente as demandas e orientações do MDA. Logo, as políticas territoriais na realidade não possuem incentivos orientados aos atores privados além das organizações sindicais e de agricultores. Os autores também evidenciaram a hesitação por parte de gestores públicos e organizações da sociedade civil em incluir os empresários nos colegiados territoriais.

A participação não é um fator limitante somente as representações privadas. Muitos trabalhos relacionados ao PTC buscaram compreender como eram operacionalizados os mecanismos de participação cidadã. Utilizando da gestão social como abordagem analítica, vários foram os pontos negativos. Pacheco (2013) abordou a qualidade da participação dos atores no Território da Cidadania Meio Oeste do Contestado (TCMOC), em Santa Catarina.

\footnotetext{
${ }^{15}$ Segundo os autores, o APL "constitui uma das novas abordagens de planejamento territorial que emergiram no cenário brasileiro, resultante do agrupamento de empresas ou unidades produtivas voltadas para a articulação dos atores sociais locais na prática de ações inovadoras que promovam a produtividade local, a partir de uma visão sistêmica da atividade econômica".
} 
Neste estudo, o autor evidencia que mesmo quando há abertura às demandas sociais das organizações da sociedade civil, estas acabam não sendo levadas em conta pelos prefeitos e gestores públicos. Tal fato desmobiliza os atores sociais e impede a criação de planos que abordem de fato a perspectiva de desenvolvimento territorial. Ademais, os colegiados impedem a participação de cidadãos sem vínculos associativos.

Poucos estudos demonstram alguma inovação de maior relevância. Podemos observar o caso do Território da Cidadania da Serra Catarinense (TCSC) abordado por Ribeiro (2012). A partir dos modelos da Habilidade Social e da Ação coletiva, o autor constata a importância dos chamados "empreendedores institucionais" na legitimação do CODETER como fórum privilegiado a promoção de ações sinérgicas. Foi evidenciado um amplo processo de aprendizagem social, incentivo ao empreendedorismo e a co-produção do bem público, além da absorção da abordagem territorial entre os atores sociais participantes. Por outro lado, ainda permanecem os dilemas da ausência de participação dos atores sociais menos organizados e estruturados, além das diretrizes engessadas do MDA, que restringe suas ações aos agricultores familiares.

Carvalho (2012) analisou a implementação do Território da Cidadania Região Central (TCRC), focando as entidades beneficiadas pelo programa no município de Santa Maria/RS. Os resultados de sua pesquisa mostram a participação ampliada de diversas cooperativas, sindicatos e organizações de agricultores familiares, inclusive os agricultores com menor renda e estrutura. Esta diversidade por si só é motivo de diversas tensões entre as demandas sociais e os recursos que os gestores oferecem. Ainda há concentração de recursos na agricultura familiar e a não tradução do proposito territorial de redução das desigualdades sociais. Mesmo com a execução de ações limitadas e parciais do programa, a autora conclui que o PTC tem subsidiado a organização das populações rurais, e tal articulação:

\footnotetext{
“tem proporcionado novas possibilidades de comercialização, subsidiado discussões sobre alternativas de produção sustentáveis, incentivado a introdução de novas culturas e a diversificação produtiva e até mesmo provocado à substituição de monoculturas como do arroz e do fumo". (CARVALHO, 2012, p. 236).
}

Um dos limites observados a implementação do PTC está relacionado à ausência de pluralidade de organizações e atores nos colegiados territoriais. Há uma concentração de representantes da agricultura familiar, principalmente dos sindicatos, que acabam por controlar a maioria dos recursos que são disponibilizados (ABRAMOVAY; MAGALHÃES, SCHRODER, 2010). O PTC não superou o desafio de aumentar a diversidade de atores da sociedade civil e das entidades privadas. Faltam mecanismos de estímulo à participação tanto 
das entidades empresariais e patronais da agricultura como os segmentos menos estruturados da agricultura familiar (FAVARETO, 2010b).

Há uma constante tensão entre o discurso da participação e diversidade e uma percepção geral de uma lógica voltada para resultados por parte dos gestores públicos. A gestão social, que deveria se o instrumento de reorganização da sociedade em torno de um objetivo comum, sequer encontra materialidade na grande maioria dos casos observados (LOPES, 2012; LORETO; SANTOS; GOMES; 2012; PACHECO, 2013).

A participação social se torna um discurso que legitima o domínio de certas organizações e redes sócio-técnicas ${ }^{16}$ que acabam por moldar as políticas públicas territoriais em torno dos seus interesses (ABRAMOVAY, MAGALHÃES, SCHORDER, 2010; SABOURIN, 2007), refletindo na distribuição assimétrica dos recursos (ORTEGA, 2014). Como consequência "os Colegiados não exprimem o conjunto das forças vidas do território que se organizam e não influem sobre as decisões quanto ao uso de seus recursos". (ABRAMOVAY, MAGALHÃES, SCHORDER, 2010, p. 285). Os colegiados perdem ao não estimularem a diversidade de atores sociais, pois a ausência desta limita o surgimento de inovações tanto no campo das ideias como no campo das práticas.

Fugindo das recomendações normativas ${ }^{17}$, entendemos que para aumentar a diversidade de participação, há a devida necessidade do reconhecimento dos diferentes atores nas políticas territoriais executadas, principalmente em referência aos agricultores com menor dotação de capital material e simbólico. Neste sentido, surgem cada vez mais estudos que reafirmam a heterogeneidade dos agricultores familiares, além do ressurgimento do debate em torno do campesinato como uma categoria de política pública (SABOURIN, 2007). Graziano da Silva, Gómez e Castañeda (2010, p. 15) sugerem que "as teorias que assinalavam a desaparição do campesinato como resultado do desenvolvimento do capitalismo no campo tem sido superado pela realidade".

Uma definição judiciosa que faça emergir a heterogeneidade da agricultura familiar se torna fundamental para a elaboração e execução de políticas públicas específicas,

\footnotetext{
${ }^{16}$ As redes sociotécnicas são formadas pela expertise de determinada área do conhecimento assimilada e compartilhada entre gestores e mediadores das políticas públicas. Esse aparato compartilhado entre os gestores acaba gerando uma relação assimétrica em relação à população em geral por serem despossuídas de tal expertise. Contudo, a interação entre os agentes sociais e as redes sociotécnicas moldam a cognição e formas de ação por parte dos agentes sociais, acabando por influir na execução da política pública com o decorrer das interações sociais. Às leitoras e leitores interessados ver: Bruno Latour. Jamais Fomos modernos. Rio de Janeiro: Editora 34, 2011. $152 \mathrm{p}$.

${ }^{17}$ Entendendo as recomendações normativas que são frequentemente repetidas na literatura: "deve-se incluir os camadas mais 'pobres' e as mais 'ricas' nos colegiados". Porém, as recomendações são realizadas sem um mínimo de reflexão sobre quais são as realidades dessas duas camadas da sociedade.
} 
direcionadas ao fortalecimento das condições de produção, do autoconsumo e dos meios para gerar excedentes econômicos comercializáveis, além da potencialização dos mercados institucionais como mecanismo de comercialização dos excedentes gerados ${ }^{18}$ (SABOURIN, 2007; SACCO DOS ANJOS; BECKER, 2014. SCHNEIDER; CASSOL, 2010).

Por outro lado, parece que a literatura tem dado pouca atenção à (não) relação dos agentes privados e das políticas de Desenvolvimento Territorial. Neste sentido, algumas questões são levantadas: Quem são os atores desta camada de produção agrícola? Como organizam sua produção e canais de comercialização? Quais são os mecanismos necessários à participação dos agricultores patronais, de representantes do empresariado, das indústrias e do comércio nos colegiados territoriais, considerando o fato destes espaços privilegiarem somente as organizações intermediárias da agricultura familiar?

Outro desafio não superado se encontra na ausência de articulação dos territórios com os entes municipais e estaduais. O PTC surge justamente para fortalecer a proposta de cooperação entre entes federados em todas as esferas de governo. Contudo, é reconhecido o grande desafio de se promover políticas territoriais no contexto historicamente marcado por relações clientelistas (KARAM, 2012), além das disputas entre partidos políticos (COELHO; FAVARETO, 2008; QUAN, 2008). Os mecanismos assimétricos de interlocução são fundamentais para compreender a dificuldade de articular relações cooperativas entre municípios, Estados e União, pois há poucos incentivos e muita desconfiança por parte dos prefeitos e estados em realizar esforços para tomar decisões em conjunto com a sociedade (GUIMARÃES, 2013).

Se a articulação em torno do desenvolvimento dos territórios entre entes federados é frágil, este fenômeno não é diferente no âmbito dos diferentes ministérios. Neste sentido, a proposta inovadora do PTC não superou os limites do discurso normativo. Não há integração entre os ministérios, que ocorre de fato é a simples disponibilidade de verbas dispersas na Matriz de Ações. O programa surgiu sob a responsabilidade do Ministério da Casa Civil justamente para promover a integração entre ministérios. Entretanto, a real gestão do PTC se dá pelo MDA, que possui reduzidas capacidades de articulação, além do que, esta não é uma competência original deste ministério (CARVALHO, 2012).

A maior parte das ações disponibilizadas nas matrizes territoriais provém dos MDS, MDA, MEC e MS. Outros ministérios, tais como Indústria e Comércio, do Turismo ou da Ciência e Tecnologia disponibilizam poucas ações, além de não se interessarem em dialogar

\footnotetext{
${ }^{18}$ Às leitoras e leitores interessados a análise da relação entre agricultura familiar e os mercados institucionais, ver: Sacco dos Anjos e Becker (2014) e Fakih (2013).
} 
efetivamente com o PTC (FAVARETO, 2009; KARAM, 2012).As expectativas em torno da integração das ações não saíram do campo da idealização. Para Favareto (2009, p. 8) "as principais ausências são as estruturas governamentais que congregam os investimentos e recursos voltados à ciência e tecnologia e outros setores que não sejam a agricultura”.

A situação se torna mais flagrante quando observamos no âmbito da União uma diversidade de iniciativas que comportam a abordagem territorial de forma implícita e explícita. Os exemplos mais relevantes são: a Agenda XXI do Ministério do Meio Ambiente, o programa das Mesorregiões diferenciadas do Ministério da Integração Nacional, e as políticas sociais sob o bojo do Ministério do Desenvolvimento Social e Combate à Fome, em particular as políticas voltadas à promoção da Segurança Alimentar que são geridas pelos Consórcios de Segurança Alimentar e Nutricional (CONSADs). As iniciativas em questão convergem tanto em objetivos quanto nas suas ações, ou seja, promover ações de organização social e estruturação econômica nas regiões mais afastadas dos polos dinâmicos a partir de uma abordagem territorial/regional. Sendo assim, apesar da abordagem inovadora contida nas proposições do PTC, podemos afirmar que houve uma inovação cosmética da abordagem territorial. O que ocorreu e ocorre de fato é que as iniciativas no âmbito do PTC mantiveram o viés setorial, financiando exclusivamente as atividades agropecuárias e o viés da política social, que foca a participação e envolvimento das organizações de agricultores familiares (FAVARETO, 2009). Ou seja, as políticas públicas de desenvolvimento territorial sustentável continuam fazendo mais do mesmo.

Isto se traduz num retrocesso da abordagem territorial como categoria de regulação da política pública. A implementação do PTC ocorreu na maioria dos casos em territórios já existentes geridos ou pelo MDA ou pelo MDS. Novamente, a proposta do PTC era integrar as iniciativas já existentes e os Planos elaborados à época do PRONAT com ampliação da oferta de políticas sociais. Contudo, o que ocorreu foi justamente ao contrário. A implementação do PTC nos territórios já existentes criou duas tensões: i) alterou a diretriz de critérios de participação, diversificando a composição dos colegiados, entrando em confronto com as estruturas e interesses consolidados; ii) a expectativa gerada pelos atores sociais em torno das reivindicações contida nos planos territoriais que em tese seriam atendidas pelo leque de ações dos ministérios. Contudo, o que ocorreu foi à oferta de ações já planejadas, ou o "cardápio de políticas" ministeriais liberadas de forma dispersa e sem articulação. Os territórios agora teriam que se moldar a tais ações, e não ao contrário. $\mathrm{O}$ resultado foi o esvaziamento generalizado dos fóruns territoriais (LOTTA; FAVARETO, 2013). 
Outro ponto crítico se revela na distribuição regional das ações do PTC. Ortega (2014) avalia que os repasses distribuídos regionalmente são em sua maioria destinados ao nordeste, em especial na linha "Direito e Desenvolvimento Social", o que reforça a direção do programa na resolução dos problemas básicos de cidadania. Por outro lado, o autor percebe que a maior parte dos investimentos do programa na região sul provinha da linha "Organização Sustentável da Produção". Neste sentido, o autor confirma que se por um lado houve uma recondução dos recursos direcionados ao nordeste, estes se limitaram as linhas de assistência às comunidades mais vulneráveis.

A prática da intervenção de cima para baixo, e o engessamento dos investimentos em diversos ministérios dispersos, o PTC passou a operar de forma contrária ao que se tinha proposto: em vez da efetivação da política integrada, o que se vê é a operação das ações sob a lógica de ofertas de recursos e linhas de ação já existentes. No sentido da mobilização popular para a criação de planos territoriais os efeitos foram mais negativos: agora não há mais a criação de projetos, mas sim a seleção restrita de prioridades dentre as ofertas ministeriais (LOTTA; FAVARETO, 2013). Logo, houve a desmobilização dos atores sociais nos colegiados com a implementação do PTC (GUIMARÃES, 2013; LOTTA; FAVARETO, 2013; KARAM, 2012; MONTENEGRO GÓMEZ; FAVARO, 2012).

Ademais, o grau de institucionalização do programa também suscita críticas e preocupações. Apesar do status diferenciado de do PTC em relação aos outros programas, o mesmo é ausente de qualquer estrutura burocrática, fundos contábeis ou qualquer tipo de orçamento próprio de gestão, mesmo com o grande aporte de recursos que o programa trabalha. A explicação para esta fragilidade são duas: i) o PTC surgiu de um decreto presidencial, não foi uma politica precedida da construção de projetos de leis passando pelo debate no Congresso Nacional e no Senado. Consequentemente, as mudanças de governo podem simplesmente retirar o programa da agenda de ações; ii) os aspectos relacionados a estrutura estatal como a má coordenação entre os entes federativos, o viés setorial das políticas, o mal uso da burocracia e o clientelismo político impedem a consolidação do programa (KARAM, 2012). Logo, se não há estrutura de gestão, a avaliação e monitoramento do PTC é feito de forma centralizada pelo MDA, sendo restritas as metas em termos de recursos alocados e empenhados, mas não há monitoramento de como os recursos foram empenhados e quais foram seus efeitos no desenvolvimento territorial (GUIMARÃES, 2013). Apesar da inovação normativa em torno do Programa Territórios da Cidadania, Lotta e Favareto (2013, p. 7) afirmam que: 
“o Programa Territórios da Cidadania operou uma incorporação fraca da abordagem territorial, promoveu uma justaposição de políticas e recursos sem alcançar uma verdadeira integração, e reproduziu os problemas de ausência de subsidiariedade, destacadamente no que diz respeito ao papel dos governos estaduais".

Em 2011, com o surgimento do Programa Brasil Sem Miséria (PBSM), o PTC perde força dentro da agenda de governo. O programa foi inovador ao promover uma política que reconheceu de fato as diversas e assimétricas realidades existentes no Brasil como um espaço privilegiado de investimento. Contudo, essa inovação se deu com parcialidade devido à persistência do viés setorial no campo e da dicotomia entre o Brasil dinâmico e o Brasil rural. A literatura abordada até o momento evidencia que a proposta a reduzir tal dicotomia tem que agir tanto na área das políticas sociais e de investimento em infraestrutura com políticas que façam aumentar a qualidade e quantidade dos recursos humanos, fornecendo tecnologias adequadas às diferentes realidades e situações (FAVARETO, 2010b).

Ademais, percebemos que além das práticas não se traduzirem na real Abordagem Territorial do Desenvolvimento Rural, está havendo um retrocesso inclusive na abordagem normativa dos programas. Se observarmos a linha histórica desde o PRONAT, passando pelos Territórios da Cidadania, ao atual PBSM, há uma clara alteração de discurso, passando da abordagem do desenvolvimento territorial para a abordagem da redução da fome e miséria (FAVARETO, 2009). Não se questiona aqui o mérito dos programas sociais. São estes programas que motivam posicionamentos entusiásticos de diversos órgãos multilaterais e acadêmicos, e são exemplos para países no mundo inteiro. O recente relatório da FAO mostra que o Brasil superou a mazela da fome ${ }^{19}$. Contudo, ficam dúvidas sobre qual está sendo o real posicionamento do governo quanto à promoção de políticas públicas que tragam a real transformação qualitativa no meio rural (ZIMMERMANN et al., 2014).

O problema em continuar fazendo o mais do mesmo, é a atual realidade do campo no Brasil. Primeiramente, estão aumentando o número de regiões mais dinâmicas concomitantemente ao aumento na quantidade de regiões menos dinâmicas, ou seja, está aumentando a disparidade socioeconômica entre as regiões. Mesmo com o quadro geral de redução da pobreza, ela ainda resiste nas regiões Norte e Nordeste, inclusive com evidências de aumento da desigualdade social (FAVARETO et al., 2014). Isso não somente no Brasil, mas a América Latina segue a mesma tendência de manutenção da pobreza no campo (GRAZIANO; GÓMEZ; CASTAÑEDA, 2010).

\footnotetext{
${ }^{19}$ Para saber mais, ver: FAO. The State of Food Insecurity in The World. Disponível em: $<$ http://www.fao.org/3/a-i4030e.pdf>. Acesso em: 18 jan. 2015.
} 
O modelo real de desenvolvimento rural atual continua sendo mais do mesmo. Houve um crescimento concentrado nas regiões onde já eram aproveitadas as vantagens comparativas regionais, ou em outros casos, houve o direcionamento da dinamização econômica. Contudo, as produções das regiões mais dinâmicas estão orientadas ao mercado externo (GRAZIANO; GÓMEZ; CASTAÑEDA, 2010). Tal modelo promoveu o aumento da concentração de latifúndios improdutivos no país. Podemos observar nos dados cadastrais do Instituto Nacional de Colonização e Reforma Agrária (INCRA) que entre os anos de 2003 e 2010, a concentração das terras em grandes propriedades aumentou em nada menos que 100 milhões de hectares. Mais de $70 \%$ das grandes propriedades são improdutivas ${ }^{20}$.

\begin{tabular}{|c|c|c|c|c|c|c|c|}
\hline \multirow[b]{2}{*}{ Classificação dos imóveis } & \multicolumn{3}{|c|}{2003} & \multicolumn{3}{|c|}{2010} & \multirow{2}{*}{$\begin{array}{c}\text { Crescimento da } \\
\text { áre a por setor } \\
2010 / 2003\end{array}$} \\
\hline & número & Áre a (há.) & $\begin{array}{l}\text { Peso s/área } \\
\text { total }\end{array}$ & núme ro & Área (há.) & $\begin{array}{l}\text { Peso s/área } \\
\text { total }\end{array}$ & \\
\hline 1. Minifundio & 2.736 .052 & 38.973 .371 & $9,30 \%$ & 3.318 .077 & 46.684 .657 & $8,20 \%$ & $19,70 \%$ \\
\hline 2. Pequena Propriedade & 1.142 .937 & 74.195 .134 & $17,70 \%$ & 1.338 .300 & 88.789 .805 & $15,50 \%$ & $19,70 \%$ \\
\hline 3. Média Proprie dade & 297.220 & 88.100 .414 & $21,10 \%$ & 380.584 & 113.879 .540 & $19,90 \%$ & $29,30 \%$ \\
\hline 4. Grande Proprie dade & 112.463 & 214.843.865 & $51,30 \%$ & 130.515 & 318.904 .739 & $55,80 \%$ & $48,40 \%$ \\
\hline a) Improdutiva & 58.331 & 133.774.802 & $31,90 \%$ & 69.233 & 228.508 .510 & $40 \%$ & $71 \%$ \\
\hline b) Produtiva & 54.132 & 81.069 .063 & $19,40 \%$ & 61.282 & 90.396 .229 & $15,80 \%$ & $11,50 \%$ \\
\hline \multirow[t]{2}{*}{ 5. Total - Brasil } & 4.290 .482 & 418.456 .641 & $100 \%$ & 5.181 .645 & 571.740 .919 & $100 \%$ & $36,60 \%$ \\
\hline & $\begin{array}{l}\text { Minifundio } \\
\text { Pq. Propriedade } \\
\text { Md. Propriedade } \\
\text { Gd. Propriedade }\end{array}$ & $\begin{array}{r}\text { at } \\
\text { de } 1 \\
\text { de } 3 \\
>\end{array}$ & $\begin{array}{l}1 \text { módulo fisc } \\
\text { a } 3 \text { módulos fis } \\
\text { a } 5 \text { módulos fis } \\
5 \text { módulos fisca }\end{array}$ & & $\begin{array}{l}\text { média de } 1,4 \\
\text { média de } 66 \\
\text { a média de } 300 \\
\text { média de } 2.44\end{array}$ & $\begin{array}{l}\text { há } \\
\text { há } \\
\text { há } \\
0 \text { há }\end{array}$ & \\
\hline
\end{tabular}

Fonte: Cadas tro do INCRA - Clas sificação segundo dados declarados pelo proprietário e de acordo com a Lei Agrária/93. Organizado por Igor Felippe. Adaptado pelo autor.

Estamos falando do mesmo modelo que outrora fora combatido por grupos de pesquisa, do mesmo modelo combatido nos discursos retóricos dos governos, o mesmo modelo que mantém a desigualdade e aumenta o numero de trabalhadores escravos no campo, o mesmo modelo que degrada os recursos naturais ainda restantes, o mesmo modelo que concentra terras em latifúndios improdutivos. Esta é uma tendência que revela desafios de grande monta na sua superação.

Há de se reconhecer que a proposta de integrar uma ampla gama de ações, em diversos ministérios, coordenada verticalmente entre entes federativos e horizontalmente entre diversos atores sociais e instituições públicas é um grande desafio dentro de uma proposta governamental que se proponha a mitigar as desigualdades históricas e relações clientelistas

\footnotetext{
${ }^{20}$ Informações obtidas a partir da reportagem de Igor Felippe, do periódico digital “Revista Fórum”. Disponível em:

$<$ http://www.revistaforum.com.br/rodrigovianna/plenos-poderes/katia-abreu-mais-de-100-milhoes-de-hectarespassaram-para-o-controle-de-latifundiarios-desde-2003/>. Acesso em 20 jan. 2015. Essas informações foram organizadas como reação às declarações da atual ministra do MAPA, Kátia Abreu, que durante a sua primeira entrevista no MAPA afirmou, entre outras pérolas mencionadas, que não havia concentração de terras no país.
} 
vigentes no país. Apesar dos limites das políticas públicas de desenvolvimento territorial, deixamos claro que os argumentos expostos acima não excluem a diversidade de ações e experiências exitosas que ocorrem nos territórios. As críticas tecidas até o momento estão centradas nos limites que as políticas esbarram para promover uma abordagem territorial que vá além da retórica.

A importância da difusão de políticas públicas de desenvolvimento territorial está refletida na expansão de pesquisas científicas voltadas tanto a reflexão do impacto do enfoque territorial como uma categoria análise científica, como para compreender os limites e alcances das políticas implementadas sob este enfoque (GUIMARÃES, 2013). A abordagem se torna cada vez mais legitima como uma ferramenta voltada à compreensão das políticas públicas territoriais (ABRAMOVAY, 20006; CAZELLA; BONNAL; MALUF, 2009).

Em síntese, temos a contribuição de Berdegué, Escobal e Bebbington (2014, p. 6-7) em torno das experiências de Desenvolvimento Territorial de 11 países da América Latina, no sentido de entender quais fatores que determinam o sucesso das experiências territoriais. A partir desta ampla análise empírica, os autores elaboraram três conclusões:

i) Há um significante número de territórios rurais na América Latina com experiências de crescimento inclusivo e sustentável;

ii) Os territórios só podem ser compreendidos quando relacionados aos grandes sistemas dos quais eles estão e fazem parte, como um resultado, mudanças progressivas nunca surgirão somente de dentro dos territórios;

iii) A história dos territórios tem um grande peso em moldar o desenvolvimento, e na América Latina esta história não está a favor das dinâmicas de crescimento inclusivo e sustentável;

Assim, dada à importância da história dos territórios e com base neste corpo de referências, podemos nos debruçar sobre Território da Cidadania Vale do Ribeira, que será abordado nas próximas páginas desta dissertação. 


\section{CAPÍTULO 5 - O TERRITÓRIO VALE DO RIBEIRA}

\subsection{Apresentação do território}

\subsubsection{Atributos ambientais}

O nome da região em questão tem sua origem na Bacia do Rio Ribeira de Iguape. O Vale do Ribeira está entre dois dos estados mais desenvolvidos do país, a sudeste de São Paulo e a Leste do Paraná e abarca vinte e dois municípios do primeiro e nove municípios do segundo, totalizando uma área de $28.306 \mathrm{~km}^{2}$, onde $39,5 \%$ correspondem ao estado do Paraná, e 60,5\% correspondem ao estado de São Paulo, como ilustra a figura abaixo.

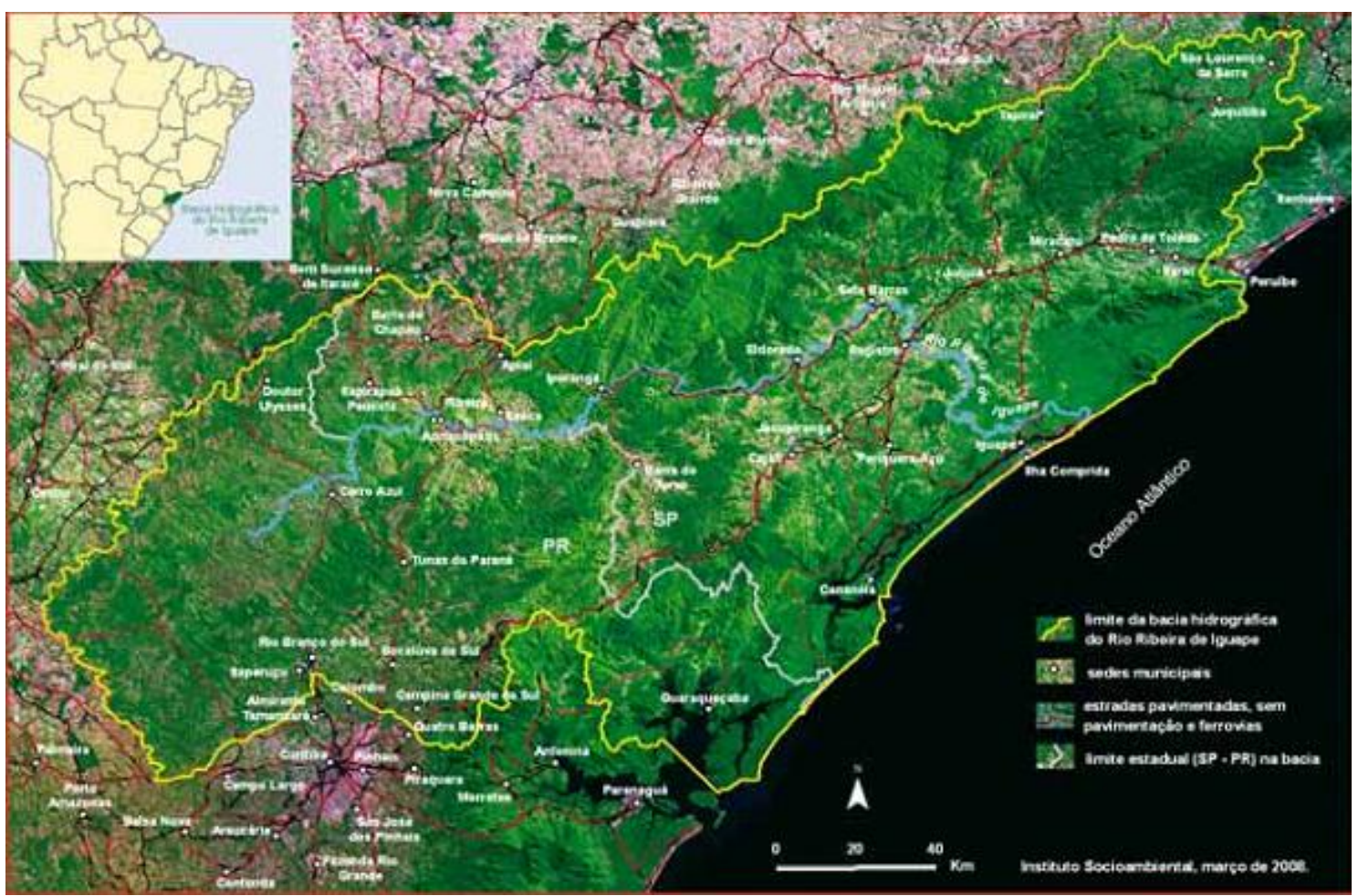

Figura 5.1 - Bacia Hidrográfica do Rio Ribeira de Iguape. Fonte: (ISA, 2008).

O Rio Ribeira de Iguape nasce da confluência dos Rios Ribeirão Grande e Açungui, no município de Cerro Azul, noroeste do estado do Paraná, com uma extensão de 470 quilômetros, sendo o único do Estado de São Paulo que não possui barragens. A sua foz se deságua no Oceano Atlântico, em específico no município de Iguape. A bacia se destaca como importante produtora de água, sendo responsável por $17 \%$ de toda a vazão média total do Estado de São Paulo (TODESCO, 2007). 


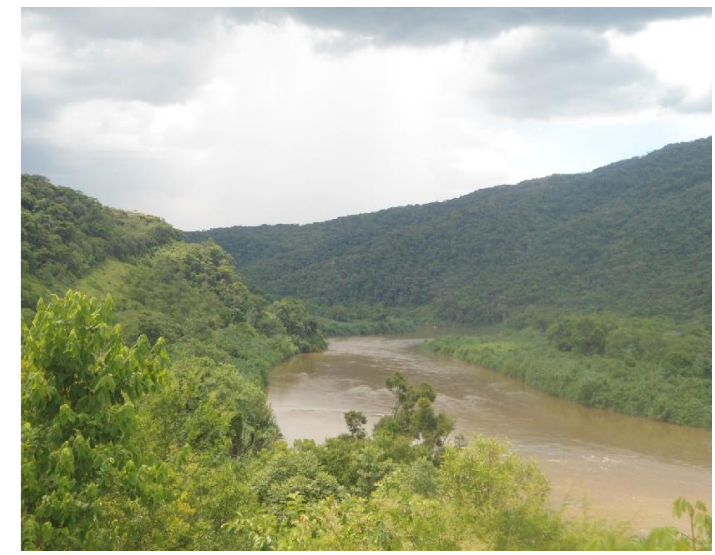

Foto 5.1 - Município de Eldorado às margens do Rio Ribeira de Iguape

Autor: Joaquim Júnior

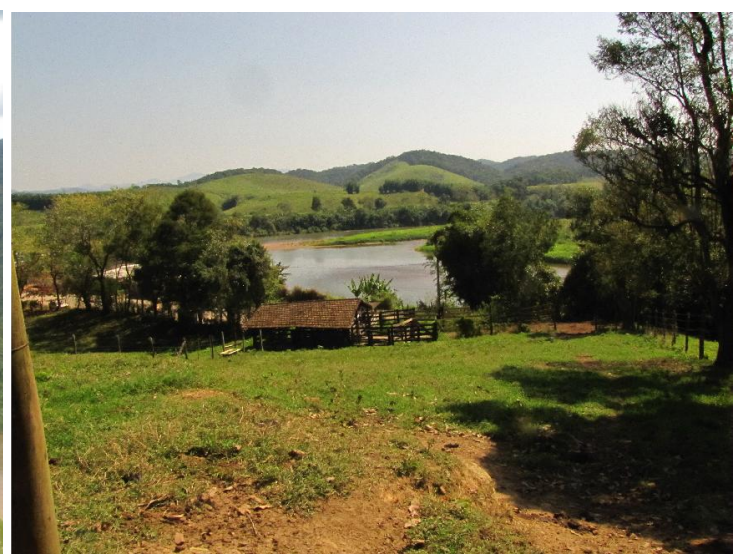

Foto 5.2 - Pousada Rural Cristina Ruivo, Eldorado Autor: Joaquim Júnior

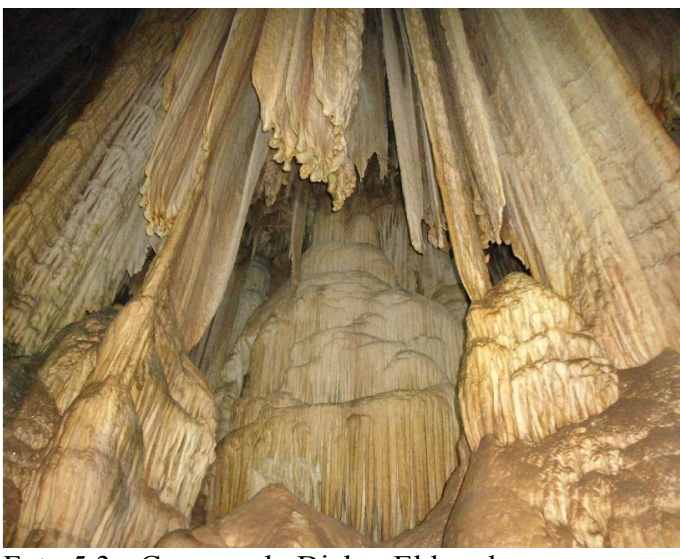

Foto 5.3 - Caverna do Diabo, Eldorado Autor: Joaquim Júnior

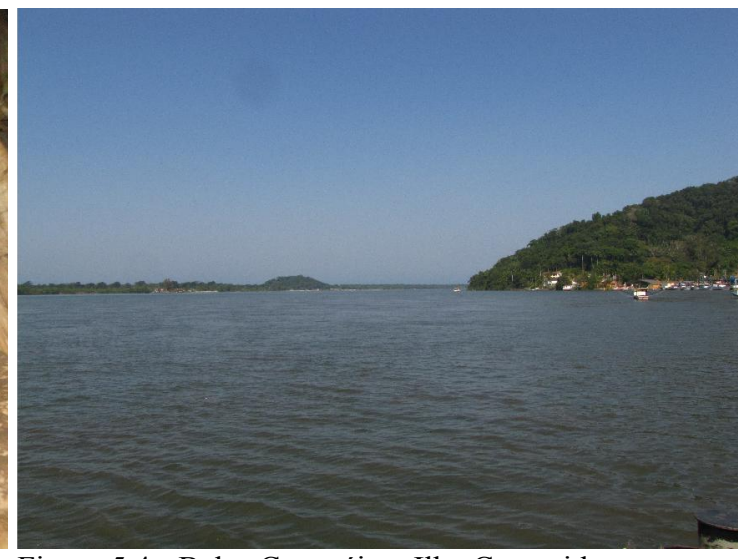

Figura 5.4 - Balsa Cananéia - Ilha Comprida Autora: Melina Leite

Nota-se como a morfologia da região induziu a atual ocupação humana. A região serrana (TODESCO, 2007), ou o Alto Vale (PETRONE, 1966), cobre aproximadamente 60\% da Bacia do Rio Ribeira de Iguape. Esta porção da região possui a maior área espeleológica da região sudeste, contendo mais de 300 cavidades naturais registradas nos municípios de Iporanga e Apiaí, contidos no Parque Turístico Alto do Ribeira (PETAR) (TODESCO, 2007).

Já a porção sublitorânea, zona de transição entre a Serra de Paranapiacaba e a baixada do ribeira, ocupa a região central do Vale do Ribeira, sendo denominada comumente como médio vale e marcada por extensas planícies por onde corre o Rio Ribeira. Nesta porção, o Rio Ribeira de Iguape se conforma uma paisagem de meandros e foi a principal área de ocupação populacional no Vale. Atualmente a região sub-litorânea possui a maior área de culturas perenes, além de ser a porção regional de maior dinâmica socioeconômica (TODESCO, 2007). 


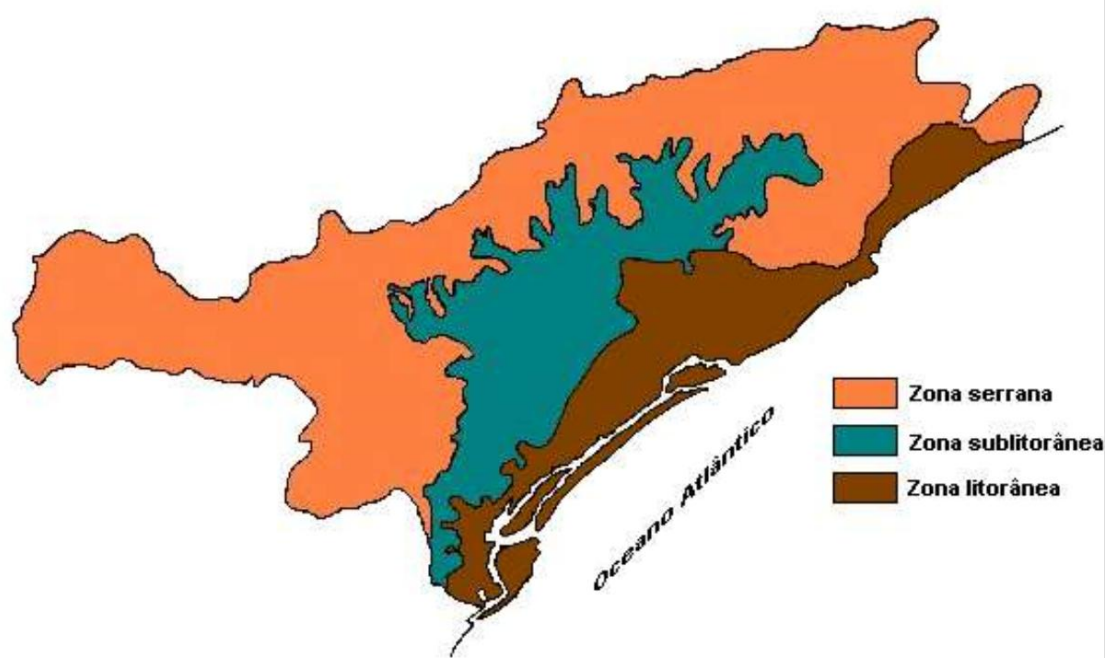

Figura 5.2 - Subdivisão geomorfológica da porção paulista do Vale do Ribeira. Fonte: Todesco, 2007.

A porção litorânea é formada por uma planície sedimentar litorânea, compõe o complexo lagunar-estuarino, que vai da Estação Ecológica Juréia-Itatins (EEJI) até a Ilha do Cardoso (TODESCO, 2007). O complexo é uma de áreas úmidas na costa brasileira com alta taxa de biodiversidade e um dos mais importantes berçários naturais do mundo $\mathrm{O}$ clima da região é tropical úmido e possui alta média de pluviosidade anual (BIM, 2012). Na porção litorânea são encontrados diversos sítios de sambaquis, marca da primeira ocupação humana da região datando de aproximadamente 8000 mil anos atrás (ADAMS, 2000, DEAN, 1996).

A porção paulista do Vale do Ribeira possui o maior índice de cobertura vegetal do Estado (BIM, 2012). Aproximadamente $60 \%$ da superfície da região possui cobertura de mata atlântica, especificamente a mata tropical úmida de floresta pluvial. Contudo, há biomas diversos referentes às matas de restingas e mangues no litoral e a florestas subtropicais úmidas na porção serrana da região (BIM, 2012; ISA, 2008). 


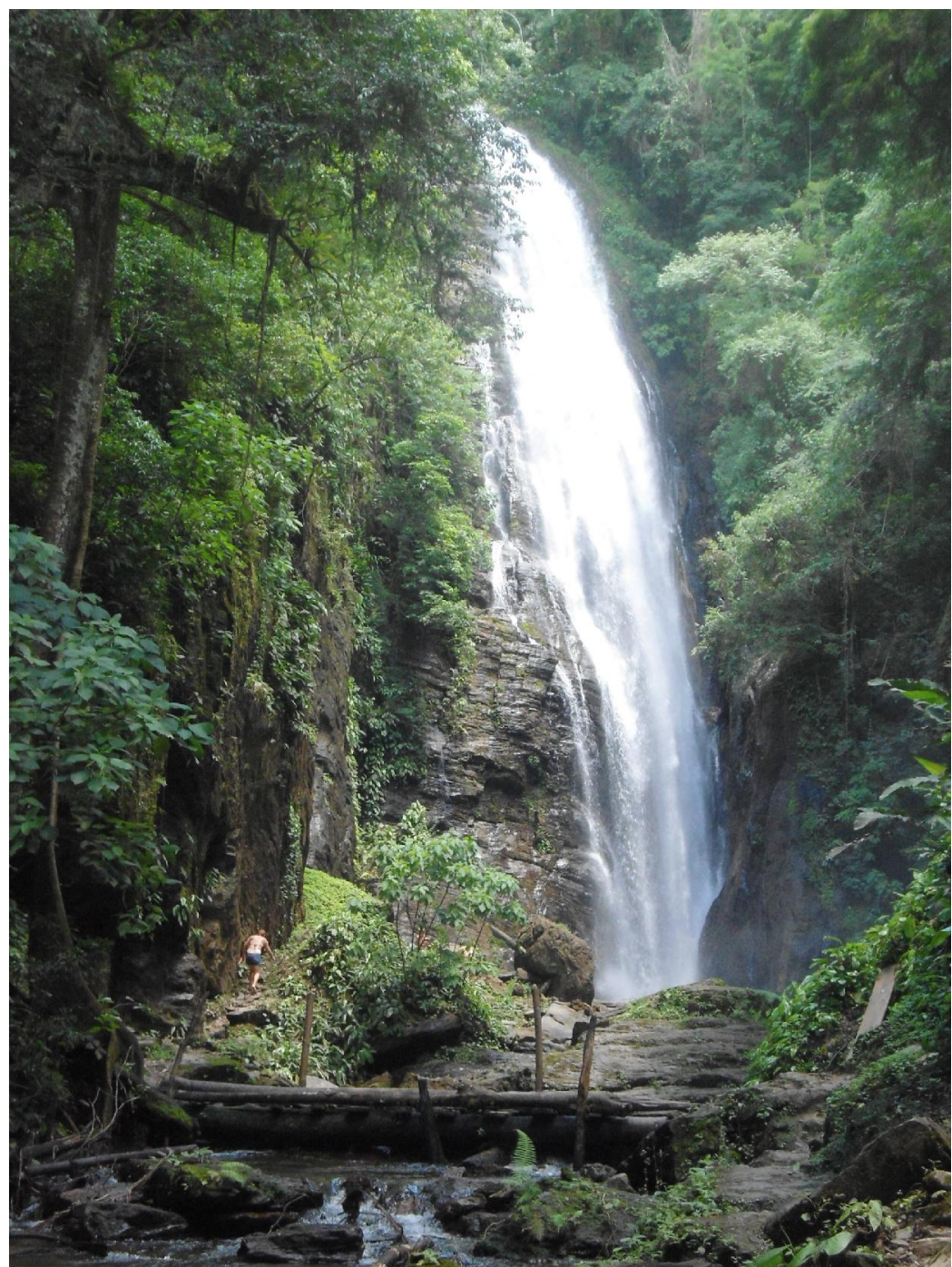

Foto 5.5 - Cachoeira de Meu Deus, Quilombo Sapatu, Eldorado Autor: Jordano Roma

Desde a década de 1950, e de forma mais intensa na década de 1980 e 1990, a preocupação com a preservação da Mata Atlântica levou a criação de uma série de Unidades de Conservação (UCs) que impediram a crescente exploração predatória dos recursos naturais da região. Cerca de $60 \%$ dos remanescentes de biodiversidade se encontram em áreas protegidas. Foram implantadas tanto UCs de proteção integração, que são unidades de domínio público e uso restrito com o objetivo de promover a preservação, quanto as UCs de uso sustentável, que promovem a estratégia da conservação, ou seja, o uso equilibrado dos recursos e a manutenção das áreas mais frágeis para preservação (BIM, 2012; RESENDE, 2002; TODESCO, 2007).

Estão listadas abaixo as UCs que existem atualmente no Vale do Ribeira. 
Tabela 5.1 - Unidades de Conservação do Território Vale do Ribeira

\begin{tabular}{|c|c|c|c|c|}
\hline \multicolumn{5}{|c|}{ Unidades de Proteção Integral } \\
\hline Ucs & Diplomas Legais & Ano de Criação & Area (há) & Municípios \\
\hline \multicolumn{5}{|l|}{ Estações Ecológicas } \\
\hline EE de Juréia-Itatins (EEJI)* & Lei Estadual n ${ }^{\circ} 5.649$, de 28/04/87 & 1987 & 79.240 & Iguape, Miracatu, Itariri e Peruíbe \\
\hline \multirow[t]{2}{*}{$\begin{array}{l}\text { EE dos Tupiniquin } \\
\text { Estação Ecológica dos Chauás }\end{array}$} & $\begin{array}{l}\text { Decreto Estadual no } 92.964 \text {, de } 21 / 07 / 86 \\
\text { Decreto Estadual n. } 12.327 \text {, de 26/09/78 }\end{array}$ & 1986 & $1,727,70$ & Peruíbe e Cananéia \\
\hline & Decreto Estadual n. ${ }^{0} 26.719$, de $06 / 02 / 87$ & 1987 & 2.699 & Iguape \\
\hline \multicolumn{5}{|l|}{ Parques Estaduais } \\
\hline PE Turístico do Alto do Ribeira (PETAR) & Decreto Estadual no 32.283 , de $19 / 05 / 58$ & 1958 & $35.772,50$ & Apiaí e Iporanga \\
\hline $\begin{array}{l}\text { PE do Rio Turvo (PERT) } \\
\text { PE Serra do Mar (Núcleo Pedro de Toledo) }\end{array}$ & $\begin{array}{l}\text { Lei Estadual } n^{0} 12.810 \text {, de } 21 / 02 / 08^{* *} \\
\text { Decreto Estadual n. }{ }^{0} 10.251 \text {, de } \\
\text { 30/08/1977 Decreto Estadual n. }{ }^{0} 13.313 \text {, } \\
\text { de } 06 / 03 / 79 \text { Decreto Estaduao n. }{ }^{0} 19.448 \text {, } \\
\text { de } 30 / 08 / 82\end{array}$ & 2008 & $73.893,87$ & Barra do Turvo, Cajati e Jacupiranga \\
\hline PE do Lagamar de Cananéia (PELC) & Lei Estadual $n^{0} 12.810$, de $21 / 02 / 08^{* *}$ & 2008 & $40.758,64$ & Cananéia e Jacupiranga \\
\hline \multirow{2}{*}{ PE da Ilha do Cardoso - PEIC } & $\begin{array}{l}\text { Decreto Estadual de } \mathrm{n}^{\circ} 40.135 \text {, de } 08 / 06 / 9 \\
\text { Decreto Estadual de n } \mathrm{n}^{\circ} 40.319 \text { de }\end{array}$ & 1995 & $41.704,27$ & Iporanga e Eldorado \\
\hline & 03/07/62 Decreto Estadual n. ${ }^{0} 9.414$ de & 1962 & 13.500 & Cananéia \\
\hline $\begin{array}{l}\text { PE "Carlos Botelho" } \\
\text { PE Campina do Encantado }\end{array}$ & $\begin{array}{l}\text { Decreto Estadual no } 19.499 \text {, de } 10 / 09 / 82 \\
\text { Lei Estadual no } 8.873 \text {, de } 16 / 08 / 94\end{array}$ & $\begin{array}{l}1982 \\
1994\end{array}$ & $\begin{array}{c}37.644 \\
3.200\end{array}$ & $\begin{array}{l}\text { Barras e Tapiraí } \\
\text { Pariquera-Açu }\end{array}$ \\
\hline $\begin{array}{l}\text { PE Caverna do Diabo } \\
\text { PE de Jacupiranga (Mosaico do Jacupiranga)** }\end{array}$ & $\begin{array}{l}\text { Lei Estadual } \mathrm{n}^{0} 12.810 \text {, de } 21 / 02 / 08^{* *} \\
\text { Decreto Estadual n. }{ }^{0} 145 \text {, de } 08 / 08 / 69 \\
\text { Lei Estadual n. } 012.810 \text {, de }\end{array}$ & 2008 & $40.219,66$ & $\begin{array}{l}\text { Barra do Turvo, Cajati, Eldorado e Iporanga } \\
\text { Jacupiranga, Iporanga, Cajati, Eldorado } \\
\text { Paulista, Barra do Turvo e Cananéia }\end{array}$ \\
\hline \multicolumn{5}{|c|}{ Unidades de Uso Sustentável } \\
\hline \multicolumn{5}{|l|}{ Áreas de Proteção Ambiental (APA) } \\
\hline \multirow[t]{3}{*}{$\begin{array}{l}\text { APA Marinha do Litoral Sul } \\
\text { APA da Ilha Comprida }\end{array}$} & Decreto Estdual n.0 53.527 de 8/10/2008 & 2008 & $357.605,53$ & Cananéia e Ilha Comprida \\
\hline & Decreto Estudal n. 26.881 de 11/03/87 & & & \\
\hline & Decreto Estadual n. ${ }^{0} 28.295$ de 21/03/88 & 1989 & 17.572 & Ilha Comprida \\
\hline APA dos Quilombos do Médio Ribeira & Lei Estadual $\mathrm{n}^{0} 12.810$, de $21 / 02 / 08^{* *}$ & 2008 & 64.000 & Barra do Turvo, Eldorado e Iporanga \\
\hline APA Cajati & Lei Estadual $\mathrm{n}^{0} 12.810$, de $21 / 02 / 08^{* *}$ & 2008 & $2.975,71$ & Cajati \\
\hline APA de Cananéia-Iguape-Peruíbe & Decreto Federal n ${ }^{0} 90.347$, de 23/10/84 & & & \\
\hline \multirow[b]{2}{*}{ APA Serra do Mar } & Decreto Federal no 91.982 , de 06/11/85 & 1985 & 234.000 & Cananéia, Iguape, Peruíbe, Itariri e Miracatu \\
\hline & $\begin{array}{l}\text { Decreto Estadual n }{ }^{\circ} 22.717 \text { de } 21 / 09 / 84 \\
\text { Decreto Estadual n. } 28.347 \text { de } 22 / 04 / 87 \\
\text { Decreto Estadual n. }{ }^{0} 26.881 \text { de } 11 / 03 / 87\end{array}$ & 1984 & $489.000,00$ & $\begin{array}{l}\text { Apiaí, Capão Bonito, Eldorado Paulista, } \\
\text { Guapiara, Ibiúna, Iporanga, Juquiá, Juquitiba, } \\
\text { Miracatu, Pedro de Toledo, Pilar do Sul, Sete } \\
\text { Barras e Tapiraí }\end{array}$ \\
\hline APA Planalto do Turvo & Lei Estadual $n^{0} 12.810$, de $21 / 02 / 08^{* *}$ & 2008 & $2.721,87$ & Barra do Turvbo \\
\hline APA Rio Vermelho e Rio Pardinho & Lei Estadual $\mathrm{n}^{0} 12.810$, de $21 / 02 / 08^{* *}$ & 2008 & $3.235,47$ & Barra do turvo \\
\hline \multicolumn{5}{|l|}{ Áreas de Relevante Interesse Ecológico (ARIE) } \\
\hline \multicolumn{5}{|l|}{ ARIE Ilha da Queimada Grande e Queimada } \\
\hline Pequena & Decreto Federal no 91.887 de $05 / 11 / 85$ & 1985 & 137,73 & Itanhaém e Peruibe \\
\hline ARIE Ilha do Ameixal & Decreto Federal no 91.889 de $05 / 11 / 85$ & 1985 & 358,88 & Iguape \\
\hline $\begin{array}{l}\text { ARIE do Guará (Área de Proteção Marinha do } \\
\text { Litoral Sul) }\end{array}$ & Decreto Estadual n ${ }^{0} 53.527$, de 8/11/08 & 2008 & 455,27 & Ilha Comprida \\
\hline \multicolumn{5}{|l|}{ Reservas Extrativistas } \\
\hline RESEX do Mandira (REMA) & Decreto Federal s/no ${ }^{\circ}$, de 13/12/2002 & 2002 & $1.177,80$ & Cananéia \\
\hline RESEX Ilha do Tumba & Lei Estadual $\mathrm{n}^{0} 12.810$, de $21 / 02 / 08^{* *}$ & 2008 & $1.128,26$ & Cananéia \\
\hline RESEX Taquari & Lei Estadual $\mathrm{n}^{0} 12.810$, de $21 / 02 / 08^{* *}$ & 20008 & $1.662,20$ & Cananéia \\
\hline \multicolumn{5}{|l|}{ Reservas de Desenvolvimento Sustentável } \\
\hline RDS Barreiro Anhemas & Lei Estadual $\mathrm{n}^{0} 12.810$, de 21/02/08** & 2008 & $3.175,07$ & Barra do Turvo \\
\hline RDS Quilombos de Barra do Turvo & Lei Estadual $\mathrm{n}^{0} 12.810$, de $21 / 02 / 08^{* *}$ & 2008 & $5.826,46$ & Barra do Turvo \\
\hline RDS Pinheirinhos & Lei Estadual $\mathrm{n}^{0} 12.810$, de $21 / 02 / 08^{* *}$ & 2008 & $1.531,09$ & Barra do Turvo \\
\hline RDS Lavras & Lei Estadual $\mathrm{n}^{0} 12.810$, de $21 / 02 / 08^{* *}$ & 2008 & 889,74 & Cajati \\
\hline RDS Itapanhapima & Lei Estadual $\mathrm{n}^{0} 12.810$, de $21 / 02 / 08^{* *}$ & 2008 & $1.242,70$ & Cananéia \\
\hline \multicolumn{5}{|l|}{ Reservas Particulares } \\
\hline RPPN denominada "Parque do Zizo" & Resolução SMA no 46 , de $05 / 11 / 13$ & 2013 & 9,2139 & Tapiraí \\
\hline RPPN "São Judas Tadeu" & Resolução SMAn ${ }^{0} 65$ de 11/09/08 & 2008 & 6,05 & Juquitiba \\
\hline
\end{tabular}

*A lei $n^{0}$ 12.406, de 12 de dezembro de 2006 alterando a Lei n ${ }^{0}$ 5.659/87 da Estação Ecológica da Juréia-Itatins e Institui o Mosaico de Unidades de Conservação da Juréia-Itatins, composto pela Estação Ecológica Juréia-Itatins, Parque Estadual Itinguçu, Parque Estadual do Prelado, Reseerva e Desenvolvimento Sustentável do Despraiado, Reserva de Desenvolvimento Sustentável da Barra do Una e Refúgios de Vida Silvestre das Ilhas do Abrigo ou Guaraú e Guararitama. Em 2009 houve o Ministério Público Estadual invalidou a Lei de criação do Mosaico, Retornando ao status de Estação Ecológica. (Narezi, 2012). Em 2013 a categoria de Mosaico é restituída com a promulgação da Lei $n^{0}$ 14. 892/2013 (PANZUTTI et al, 2013).

** A lei n 0 12.810, de 21 de fevereiro de 2008, altera a área do Parque Estadual de Jacupiranga e Institui o Mosaico de Unidades de Conservação do Jacupiranga. 


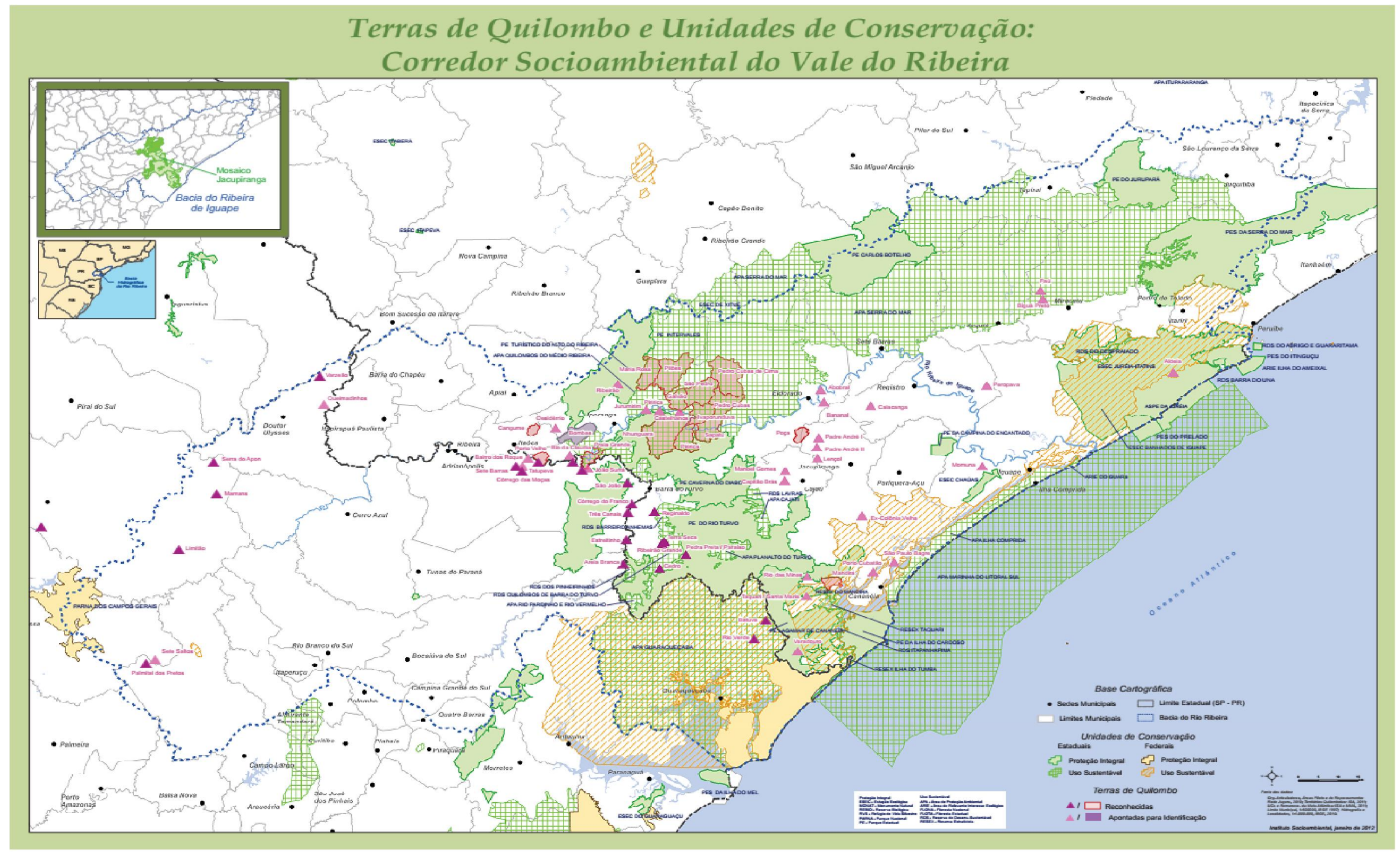

Figura 5.3 - Mapa das Unidades de Conservação do Vale do Ribeira. Fonte: ISA, (2012). 
A implantação das UCs contribuiu de forma parcial para combater a degradação das florestas que haviam se intensificado no final do século XX. Porém, a maior parte das UCs foi instituída com base na estratégia preservacionista. Tal estratégia não considerou as comunidades tradicionais e de agricultores familiares que viviam dentro ou próximos as unidades. Este é o motivo de um dos principais conflitos entre comunidades locais e os órgãos ambientais do Estado de São Paulo (FERREIRA, 2004; RESENDE, 2002; TODESCO, 2007).

É importante ressaltar que os dados referentes aos perímetros das UCs são valores aproximados. Apesar das diplomações das áreas, na verdade, não há compreensão nem por parte dos gestores sobre quais são as áreas corretas das UCs, geralmente porque as decisões em sua maioria são aleatórias e sem a precedência de estudos e diagnósticos (RESENDE, 2002).

\subsubsection{Caracterização socioeconômica}

A região guarda uma importante riqueza sociocultural. O Vale do Ribeira é reduto de inúmeras comunidades tradicionais. Segundo o último levantamento mais recente (ANDRATE; TATTO, 2013), há 66 comunidades quilombolas na região. Além disso, a região contém 13 comunidades indígenas (COMISSÃO PRÓ-ÍNDIO, 2013) e aproximadamente 80 comunidades caiçaras (RABINOVIC, 2012).

Além das comunidades tradicionais, o processo histórico de ocupação do país refletiu nas investidas de colonização estrangeira, que se deu tanto por incentivos lançados pelos governos estrangeiros em cooperação com o Brasil, como por livre iniciativa de grupos imigrantes e migrantes que iam para a região. (PETRONE, 1966).

A configuração do Território Vale do Ribeira (TVR), objeto central do nosso estudo, é formada por 25 municípios: Apiaí, Barra do Chapéu, Barra do Turvo, Cajati, Cananéia, Eldorado, Iguape, Ilha Comprida, Iporanga, Itaóca, Itapirapuã Paulista, Itariri, Jacupiranga, Juquiá, Juquitiba, Miracatu, Pariquera-Açu, Pedro de Toledo, Peruíbe, Registro, Ribeira, Ribeirão Branco, São Lourenço da Serra, Sete Barras e Tapiraí. Abaixo temos o mapa da configuração territorial do Vale do Ribeira. 


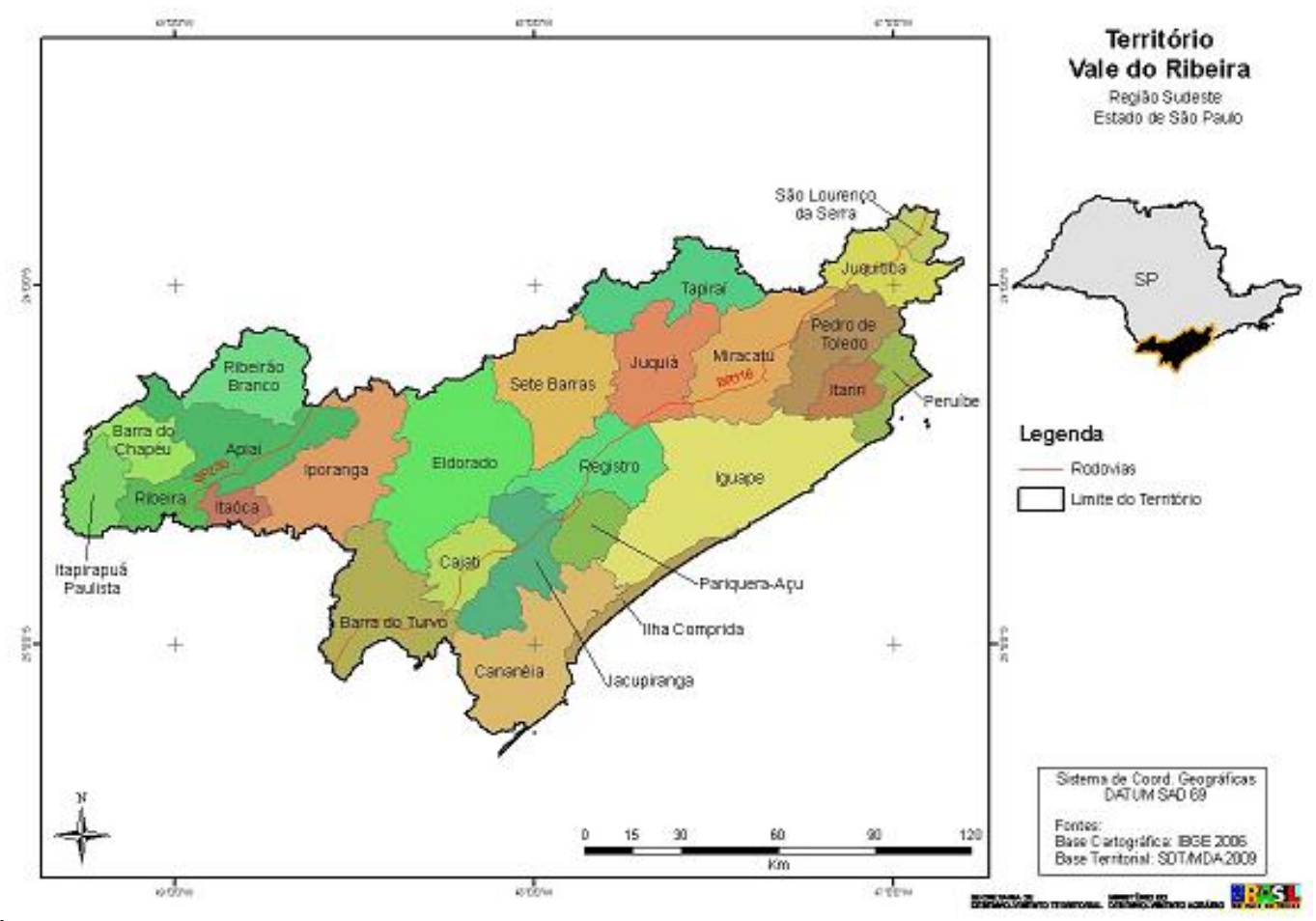

Figura 5.4. Mapa do Território Vale do Ribeira, São Paulo, SP. Fonte: MDA (2010).

O TVR abriga apenas $1 \%$ da população paulista com 447.139 habitantes, e cobre aproximadamente $7 \%$ da área total do Estado de São Paulo. É a região com menor taxa de urbanização e menor densidade demográfica, além da menor taxa de crescimento do Estado nos períodos recentes.

Nos últimos anos houve uma importante redução da população rural concomitante ao incremento da população urbana. Isso representou em termos absolutos que 24.871 habitantes deixaram as áreas rurais, uma redução de quase $19 \%$ nos últimos dez anos. Por outro lado, o incremento da população urbana foi de $9,6 \%$, ou 32.400 habitantes em termos absolutos. Ou seja, houve um aumento de apenas 7.529 indivíduos na região entre 2004 e 2014. O crescimento populacional da região durante o período foi cerca de 1,7\%. Este percentual é muito menor quando relacionado ao do Estado de São Paulo, que chegou ao patamar de 10\%. 
Tabela 5.2 - População Total, Rural e Urbana (valores absolutos e relativos), Área Densidade Demográfica e Variação Populacional dos Municípios do Vale do Ribeira

\begin{tabular}{|c|c|c|c|c|c|c|c|c|c|c|c|c|c|c|}
\hline \multirow[b]{2}{*}{ Município } & \multicolumn{2}{|c|}{ Pop. rural (2014) } & \multicolumn{2}{|c|}{ Pop. Urbana (2014) } & \multicolumn{3}{|c|}{ Pop. Total Área Km2:ns. Dem } & \multicolumn{2}{|c|}{ População 2004} & \multicolumn{2}{|c|}{ População 2014} & \multicolumn{2}{|c|}{ Pop. Total } & \multirow{2}{*}{$\begin{array}{c}\text { Variação } \\
(\%) \\
\end{array}$} \\
\hline & $\mathbf{N}^{0}$ absoluto & $(\%)$ & $\mathbf{N}^{0}$ absolutc & $(\%)$ & 2014 & & $\left(\mathbf{h a b} / \mathbf{k m}^{2}\right)$ & Urbana & Rural & Urbana & Rural & 2004 & 2014 & \\
\hline Apiaí & 5.925 & 23,89 & 18.878 & 76,11 & 24.803 & 454,44 & 25,46 & 17.248 & 9.400 & 18.878 & 5.925 & 26.648 & 24.803 & $-6,92$ \\
\hline Barra do Chapéu & 3.776 & 70,55 & 1.576 & 29,45 & 5.352 & $1.239,38$ & 13,19 & 1.484 & 3.539 & 1.576 & 3.776 & 5.023 & 5.352 & 6,55 \\
\hline Barra do Turvo & 4.349 & 56,67 & 3.325 & 43,33 & 7.674 & $1.977,95$ & 7,61 & 2.988 & 5.013 & 3.325 & 4.349 & 8.001 & 7.674 & $-4,09$ \\
\hline Cajati & 7.550 & 26,51 & 20.929 & 73,49 & 28.479 & $1.152,05$ & 62,67 & 20.805 & 8.253 & 20.929 & 7.550 & 29.058 & 28.479 & $-1,99$ \\
\hline Cananéia & 1.708 & 13,98 & 10.507 & 86,02 & 12.215 & 183,02 & 9,86 & 10.208 & 2.068 & 10.507 & 1.708 & 12.276 & 12.215 & $-0,50$ \\
\hline Eldorado & 7.512 & 50,79 & 7.278 & 49,21 & 14.790 & 273,67 & 8,94 & 6.907 & 7.516 & 7.278 & 7.512 & 14.423 & 14.790 & 2,54 \\
\hline Iguape & 3.864 & 13,31 & 25.167 & 86,69 & 29.031 & 704,09 & 14,68 & 22.947 & 5.280 & 25.167 & 3.864 & 28.227 & 29.031 & 2,85 \\
\hline Ilha Comprida & 0 & 0,00 & 9.515 & 100,00 & 9.515 & 812,75 & 49,57 & 7.581 & 0 & 9.515 & 0 & 7.581 & 9.515 & 25,51 \\
\hline Iporanga & 1.737 & 40,11 & 2.594 & 59,89 & 4.331 & 522,18 & 3,76 & 2.198 & 2.272 & 2.594 & 1.737 & 4.470 & 4.331 & $-3,11$ \\
\hline Itaóca & 1.453 & 45,48 & 1.742 & 54,52 & 3.195 & 359,3 & 17,46 & 1.988 & 1.268 & 1.742 & 1.453 & 3.256 & 3.195 & $-1,87$ \\
\hline Itapirapuã Paulista & 1.998 & 50,20 & 1.982 & 49,80 & 3.980 & 670,44 & 9,79 & 1.741 & 1.987 & 1.982 & 1.998 & 3.728 & 3.980 & 6,76 \\
\hline Itariri & 5.326 & 32,93 & 10.848 & 67,07 & 16.174 & 324,14 & 59,10 & 8.323 & 6.043 & 10.848 & 5.326 & 14.366 & 16.174 & 12,59 \\
\hline Jacupiranga & 7.819 & 45,55 & 9.346 & 54,45 & 17.165 & 722,41 & 24,38 & 9.738 & 7.411 & 9.346 & 7.819 & 17.149 & 17.165 & 0,09 \\
\hline Juquiá & 6.831 & 35,99 & 12.150 & 64,01 & 18.981 & $1.062,70$ & 23,35 & 12.282 & 7.950 & 12.150 & 6.831 & 20.232 & 18.981 & $-6,18$ \\
\hline Juquitiba & 5.532 & 18,85 & 23.816 & 81,15 & 29.348 & 191,7 & 56,20 & 19.127 & 8.484 & 23.816 & 5.532 & 27.611 & 29.348 & 6,29 \\
\hline Miracatu & 9.575 & 47,54 & 10.566 & 52,46 & 20.141 & 974,32 & 20,11 & 10.752 & 11.091 & 10.566 & 9.575 & 21.843 & 20.141 & $-7,79$ \\
\hline Parique ra-Açu & 5.730 & 30,52 & 13.044 & 69,48 & 18.774 & 405,68 & 52,25 & 12.065 & 5.941 & 13.044 & 5.730 & 18.006 & 18.774 & 4,27 \\
\hline Pedro de Toledo & 3.186 & 30,35 & 7.311 & 69,65 & 10.497 & $1.007,82$ & 15,66 & 6.473 & 3.152 & 7.311 & 3.186 & 9.625 & 10.497 & 9,06 \\
\hline Peruíbe & 544 & 0,87 & 61.763 & 99,13 & 62.307 & $1.654,26$ & 192,22 & 53.483 & 1.418 & 61.763 & 544 & 54.901 & 62.307 & 13,49 \\
\hline Registro & 6.069 & 11,23 & 47.989 & 88,77 & 54.058 & 406,48 & 74,83 & 44.871 & 9.486 & 47.989 & 6.069 & 54.357 & 54.058 & $-0,55$ \\
\hline Ribeira & 1.967 & 59,70 & 1.328 & 40,30 & 3.295 & $1.001,54$ & 9,81 & 1.095 & 2.385 & 1.328 & 1.967 & 3.480 & 3.295 & $-5,32$ \\
\hline Ribeirão Branco & 8.161 & 45,71 & 9.694 & 54,29 & 17.855 & 335,75 & 25,60 & 9.094 & 11.347 & 9.694 & 8.161 & 20.441 & 17.855 & $-12,65$ \\
\hline São Lourenço da Serra & 1.181 & 8,09 & 13.414 & 91,91 & 14.595 & 697,5 & 78,33 & 11.470 & 1.498 & 13.414 & 1.181 & 12.968 & 14.595 & 12,55 \\
\hline Sete Barras & 4.715 & 36,96 & 8.041 & 63,04 & 12.756 & 186,33 & 12,00 & 5.537 & 7.983 & 8.041 & 4.715 & 13.520 & 12.756 & $-5,65$ \\
\hline Tapiraí & 2.114 & 27,01 & 5.714 & 72,99 & 7.828 & 755,1 & 10,37 & 5.712 & 2.708 & 5.714 & 2.114 & 8.420 & 7.828 & $-7,03$ \\
\hline Vale do Ribeira & 108.622 & 32,91 & 338.517 & 67,09 & 447.139 & 18.075 & 35,09 & 306.117 & 133.493 & 338.517 & 108.622 & 439.610 & 447.139 & 1,71 \\
\hline São Paulo & 1.618.489 & 3,79 & 41.054.897 & 96,21 & 42.673.386 & 248.223.21 & 170,43 & 36.452.533 & 2.318.280 & 41.054.897 & 1.618.489 & 38.770 .813 & 42.673.386 & $\mathbf{1 0 , 0 7}$ \\
\hline
\end{tabular}

Fonte: SEADE, 2014. Organizado pelo autor. 
Este fenômeno indica um uma variação da população entre os municípios do próprio território (GALVANESE, 2009). Entre o período de 2004 e 2014, dentre os 25 municípios, cinco (São Lourenço da Serra, Peruíbe, Pedro de Toledo, Itariri e Ilha Comprida) apresentamse como locais "atraentes", pois possuem crescimento populacional próximo ao da média estadual. Outros seis municípios (Pariquera-Açu, Juquitiba, Itapirapuã Paulista, Iguape, Eldorado e Barra do Chapéu) são considerados municípios “estagnados”, apresentando crescimento populacional inferior à média estadual. Já outros 13 municípios (Tapiraí, Sete Barras, Ribeirão Branco, Ribeira, Registro, Miracatu, Juquiá, Jacupiranga, Itaóca, Iporanga, Cananéia, Cajati Barra do Turvo e Apiaí) são considerados municípios "esvaentes", devido à perda líquida de população no período considerado.

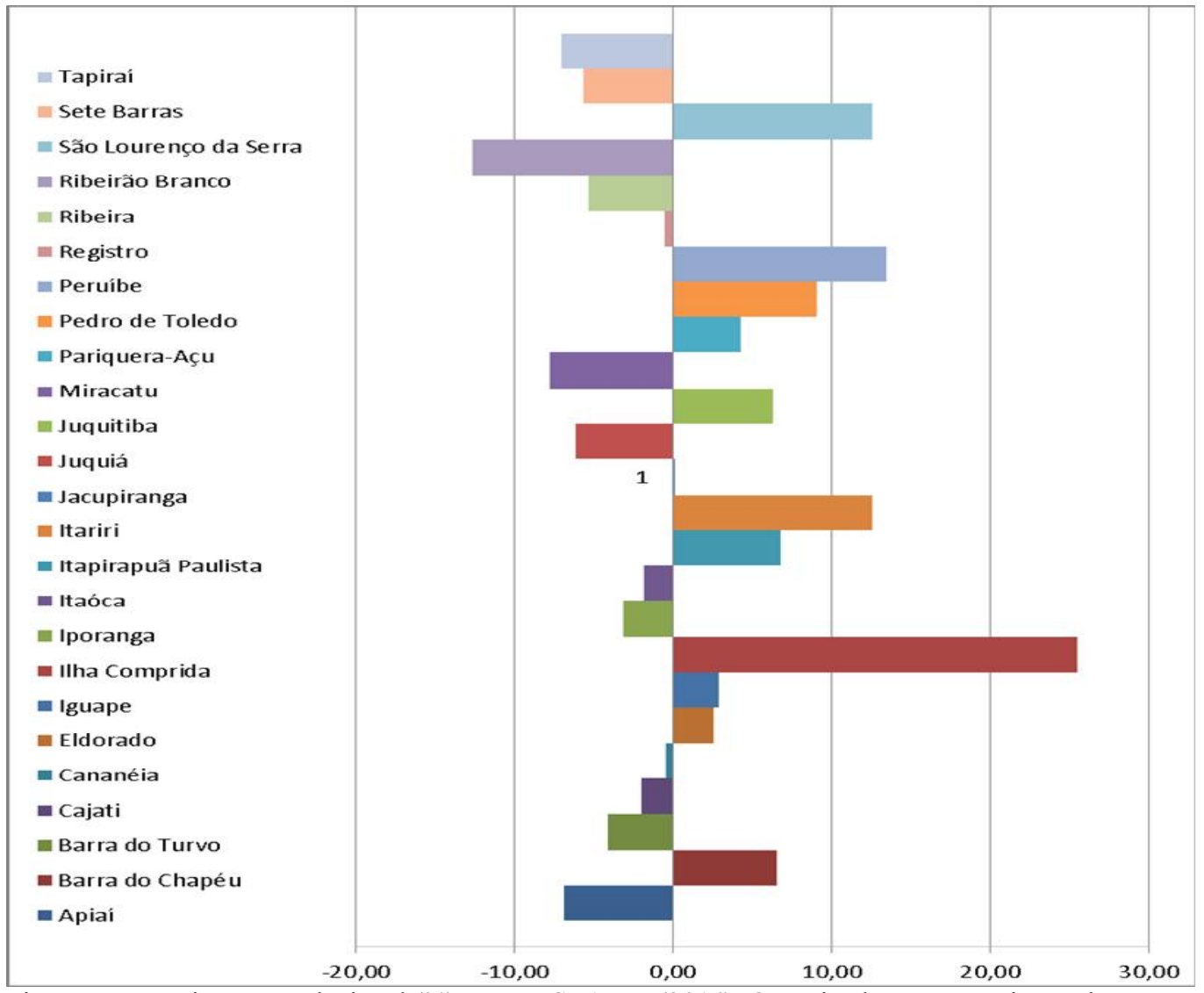

Figura 5.5 - Variação populacional (\%). Fonte: SEADE, (2014). Organizado por: Joaquim Júnior

Os indicadores relativos à qualidade de vida são expressos pelo Índice de Desenvolvimento Humano Municipal (IDHM). Temos para o território em tela que a maior parte dos municípios possuem IDHMs considerados médios (valor entre 0,5 e 0,799), referente ao componente renda. Os indicadores do componente longevidade também são considerados médios em sua maioria, com poucas exceções positivas como o caso de Cajati e Cananéia. Mas é o atributo educação que possui os melhores indicadores regionais, tendo um 
IDHM alto (valor acima de 0,799 ) na maior parte do território, com algumas exceções como Barra do Turvo e Itapirapuã Paulista.

Tabela 5.3 - Índice de Desenvolvimento Humano Municipal do Território Vale do Ribeira

\begin{tabular}{lccccc}
\hline \multicolumn{1}{c}{ Município } & IDHM & $\begin{array}{c}\text { IDHM- } \\
\text { Educação }\end{array}$ & $\begin{array}{c}\text { IDHM- } \\
\text { Longevidade }\end{array}$ & IDHM-Renda & Gini-Renda \\
\hline Apiaí & 0,72 & 0,85 & 0,67 & 0,63 & 0,62 \\
Barra do Chapéu & 0,65 & 0,78 & 0,6 & 0,56 & 0,6 \\
Barra do Turvo & 0,66 & 0,76 & 0,67 & 0,56 & 0,62 \\
Cajati & 0,75 & 0,81 & 0,81 & 0,63 & 0,56 \\
Cananéia & 0,78 & 0,83 & 0,81 & 0,68 & 0,59 \\
Eldorado & 0,73 & 0,82 & 0,74 & 0,63 & 0,61 \\
Iguape & 0,76 & 0,86 & 0,72 & 0,69 & 0,6 \\
Ilha Comprida & 0,8 & 0,89 & 0,79 & 0,74 & 0,6 \\
Iporanga & 0,69 & 0,8 & 0,69 & 0,59 & 0,6 \\
Itaóca & 0,65 & 0,8 & 0,6 & 0,55 & 0,62 \\
Itapirapuã Paulista & 0,65 & 0,76 & 0,6 & 0,58 & 0,61 \\
Itariri & 0,75 & 0,84 & 0,72 & 0,69 & 0,59 \\
\hline Jacupiranga & 0,76 & 0,83 & 0,74 & 0,71 & 0,6 \\
Juquiá & 0,74 & 0,82 & 0,72 & 0,68 & 0,59 \\
Juquitiba & 0,75 & 0,85 & 0,75 & 0,67 & 0,51 \\
Miracatu & 0,75 & 0,82 & 0,76 & 0,66 & 0,59 \\
\hline Pariquera-Açu & 0,77 & 0,86 & 0,76 & 0,69 & 0,6 \\
Pedro de Toledo & 0,73 & 0,82 & 0,69 & 0,67 & 0,58 \\
Peruíbe & 0,78 & 0,87 & 0,74 & 0,73 & 0,58 \\
\hline Registro & 0,78 & 0,87 & 0,74 & 0,72 & 0,65 \\
\hline Ribeira & 0,68 & 0,78 & 0,67 & 0,58 & 0,59 \\
Ribeirão Branco & 0,65 & 0,78 & 0,6 & 0,57 & 0,59 \\
São Lourenço da Serra & 0,77 & 0,85 & 0,78 & 0,69 & 0,58 \\
Sete Barras & 0,73 & 0,81 & 0,76 & 0,62 & 0,6 \\
\hline Tapiraí & 0,74 & 0,81 & 0,73 & 0,67 & 0,59 \\
\hline Média Território & $\mathbf{0 , 7 2 8 8}$ & $\mathbf{0 , 8 2 2 8}$ & $\mathbf{0 , 7 1 4 4}$ & $\mathbf{0 , 6 4 7 6}$ & $\mathbf{0 , 5 9 4 8}$ \\
\hline Fonte: MDA, & & & &
\end{tabular}

Fonte: MDA, 2015.

Apesar do IDHM no componente educação estar relativamente estável, quando comparado com o mesmo indicador para o Estado de São Paulo encontramos uma diferença relevante em termos percentuais. A taxa média de analfabetismo do vale é cerca de três vezes maior que a média do estado. Além disso, a porcentagem da população adulta com o diploma o ensino médio é cerca de $50 \%$, enquanto no Estado beira aos $70 \%$. 
Tabela 5.4 - Taxa de Analfabe tis mo e taxa da população com ensino médio

$\begin{array}{ccc} & \text { Taxa de Analfabetismo da } & \text { População de } 18 \text { a } 24 \text { Anos com } \\ \text { Municípios (2010) } & \begin{array}{c}\text { População de } 15 \text { Anos ou Mais } \\ \text { (Em \%) }\end{array} & \begin{array}{c}\text { Ensino Médio Completo (Em \%) } \\ \text { Ensom }\end{array} \\ & & \end{array}$

\begin{tabular}{lcc}
\hline Barra do Turvo & 17,10 & 27,69 \\
Sete Barras & 10,49 & 33,48 \\
\hline Itariri & 9,32 & 36,63 \\
\hline Ribeirão Branco & 12,24 & 38,81 \\
Tapirá & 10,95 & 42,38 \\
Cajati & 9,94 & 42,51 \\
\hline Ilha Comprida & 5,07 & 43,59 \\
Eldorado & 11,23 & 43,68 \\
Peruíbe & 6,05 & 44,22 \\
\hline Itapirapuã Paulista & 12,98 & 46,42 \\
\hline Juquiá & 11,06 & 48,52 \\
\hline Iguape & 8,00 & 48,66 \\
\hline Jacupiranga & 9,36 & 48,70 \\
Apiaí & 7,63 & 49,35 \\
Miracatu & 10,31 & 50,61 \\
\hline Barra do Chapé u & 12,26 & 50,70 \\
\hline Pedro de Tole do & 10,25 & 52,18 \\
\hline Cananéia & 7,61 & 53,57 \\
\hline São Loure nço da Se & 8,22 & 53,71 \\
\hline Pariquera-Açu & 6,79 & 54,18 \\
\hline Juquitiba & 10,83 & 55,67 \\
\hline Iporanga & 12,50 & 56,74 \\
Ribeira & 12,48 & 57,61 \\
Registro & 5,58 & 58,32 \\
Itaóca & 15,72 & 61,01 \\
\hline Região & $\mathbf{9 , 9 3}$ & $\mathbf{4 7 , 4 1}$ \\
\hline Estado(2012) & $\mathbf{3 , 8 1}$ & $\mathbf{6 9 , 5}$ \\
\hline Fonte: SEADE, &
\end{tabular}

Fonte: SEADE, 2014. Organizado pelo autor

Além disto, há um baixo número de unidades de ensino superior por um lado, e uma expansão dos cursos de ensino técnico no território por outro (MDA, 2010). Em relação ao ensino técnico, há três Escolas Técnicas Estaduais (ETECs), em Iguape, em Registro, em Peruíbe, em Apiaí, além de um Núcleo de Formação Profissional em Agroecologia no Quilombo André Lopes, município de Eldorado. Ambas as escolas e núcleo são geridas pelo Centro Paula e Souza ${ }^{21}$. Recentemente o Instituto Federal de Educação, Ciência e Tecnologia (IF) montou uma sede em Registro para oferecer cursos do Programa Nacional de Acesso ao

\footnotetext{
${ }^{21}$ Centro Paula e Souza. Disponível em: <http://www.centropaulasouza.sp.gov.br/>. Acesso em 15 jan. 2015.
} 
Ensino Técnico e Emprego ${ }^{22}$ (PRONATEC). O IF também realizou algumas experiências com a realização de cursos do PRONATEC em outros municípios com unidades remotas de ensino. As unidades remotas tem o objetivo de estruturar o local onde serão realizados os cursos. Este lugar é disponibilizado pela prefeitura, e o IF contrata os professores para ministrar os cursos. Já houve alguns resultados, como no município de Jacupiranga ${ }^{23}$, mas a ação ainda se mostra incipiente em relação à demanda existente.

Em relação às universidades publicas e privadas há uma Universidade Estadual Paulista (UNESP) em Registro, com curso de Agronomia. Além disso, há a Faculdade Vale do Ribeira em Registro, a Faculdade Peruíbe e a Faculdade de São Lourenço da Serra. Todas estas unidades são mantidas pela União das Instituições de Serviço, Ensino e Pesquisa, Ltda ${ }^{24}$. (UNISEPE).

Abaixo temos o quadro comparativo do número de matriculados em universidades do território em relação ao Estado $^{25}$.

Tabela 5.5 - Matrículas em Curso de Graduação Presencial

\begin{tabular}{lrrr}
\hline & $\begin{array}{l}\text { Números } \\
\text { absolutos }\end{array}$ & População & $(\%)$ \\
\hline Vale do Ribeira & 3251 & 447.139 & 0,727067 \\
Estado & 1.573 .684 & 42.673 .386 & 3,687741 \\
\hline
\end{tabular}

Fonte: SEADE, 2014. Organizado pelo autor.

Em relação às informações de geração de emprego e renda, entre o período de 2002 a 2012 houve um crescimento de 19.747 empregos formais na região. Este fenômeno representa um acréscimo de cerca de $40 \%$ dos postos de empregos gerados durante o período. O aumento se deu de forma ascendente em todos os setores (Agropecuária e exploração florestal, Comércio e Serviços e Indústria). Porém, quando se olha no âmbito dos municípios fica perceptível que o crescimento ocorre dos empregos na região ocorre de forma heterogênea (Tabela 5.6).

22 Instituto Federal de Educação, Ciência e Tecnologia, Campus Registro. Disponível em: < http://rgt.ifsp.edu.br/portal/>. Acesso em: 15 jan. 2015.

${ }^{23}$ PRONATEC qualifica 119 pessoas em seis cursos diferentes em Jacupiranga. Portal "O Vale do Ribeira. Disponível em: <http://www.portalvaledoribeira.com.br/2015/01/08/pronatec-qualifica-119-pessoas-em-seiscursos-diferentes-em-jacupiranga/>. Acesso em: 15 jan. 2015.

${ }^{24}$ Portal UNISEPE. Disponível em: <http://www.unisepe.edu.br/>. Acesso em 15 jan. 2015.

${ }^{25}$ Nos dados da Fundação SEADE nos informou que não haviam matrículas no município de São Lourenço da Serra. 
A cidade polo da região, Registro, continua sendo a mais importante geradora de empregos em termos absolutos, concentrando praticamente $20 \%$ dos empregos formais na região. Registro foi uma das únicas cidades onde houve crescimento do emprego em todos os setores da economia.

Além de Registro, as cidades que aumentaram o emprego em todos os setores foram: i) Apiaí, especialmente na área de comércio e serviços; ii) Cajati, que possui uma importância na indústria, aumentou significativamente os empregos formais na área da construção e dos serviços, e iii) Peruíbe, que viu seu setor de comércios e serviços mais que dobrar a quantidade de emprego gerada no período.

A maior parte dos municípios do território teve no setor de serviços a alavanca para o aumento de empregos, com poucas exceções. Duas delas são observadas nos município de Ribeirão Branco e Eldorado, onde os empregos na área da agricultura aumentaram cerca de $70 \%$ e $60 \%$, respectivamente, durante o período.

Dentre os exemplos de municípios onde houve redução na geração de empregos temos: i) Iporanga, com perdas de emprego na área do comércio; ii) Juquitiba com uma severa perda de $75 \%$ e $54 \%$ na indústria e serviços, respectivamente e, iii) São Lourenço da Serra, que perdeu empregos em todos os setores, com exceção do ganho de empregos no setor da agricultura em torno de $60 \%$.

No geral, comparando a população total do Vale do Ribeira com o número de empregos gerados, temos uma proporção de aproximadamente $15 \%$ de pessoas trabalhando (excluindo a taxa da população economicamente ativa). Se fizermos a mesma conta para o estado de São Paulo, este percentual mais que dobra, indo para $32 \%$ do total da população. 
Tabela 5.6 - Variação dos empregos gerados por setor da Economia entre 2002 e 2012

\begin{tabular}{|c|c|c|c|c|c|c|c|c|c|c|c|c|c|}
\hline \multirow[b]{2}{*}{ Municípios } & \multirow{2}{*}{$\begin{array}{c}\text { Agricultura } \\
2002 \\
\end{array}$} & \multicolumn{2}{|r|}{ Indústria } & \multicolumn{2}{|r|}{ Construção } & \multicolumn{2}{|r|}{ Comércio } & \multicolumn{2}{|r|}{ Serviços } & \multicolumn{2}{|r|}{ Total } & \multicolumn{2}{|c|}{ Variação } \\
\hline & & 2012 & 2002 & 2012 & 2002 & 2012 & 2002 & 2012 & 2002 & 2012 & 2002 & 2012 & $\%)$ \\
\hline Apiaí & 1.119 & 1.367 & 395 & 397 & 25 & 316 & 377 & 870 & 1.082 & 1.839 & 2.998 & 4.789 & 59,74 \\
\hline Barra do Chapéu & 66 & 297 & 2 & 0 & 0 & 0 & 5 & 46 & 192 & 231 & 265 & 574 & 116,6 \\
\hline Barra do Turvo & 26 & 28 & 7 & 15 & 12 & 0 & 60 & 82 & 201 & 415 & 306 & 540 & 76,47 \\
\hline Cajati & 570 & 772 & 753 & 971 & 123 & 996 & 611 & 1.019 & 1.542 & 1.812 & 3.599 & 5.570 & 54,77 \\
\hline Cananéia & 107 & 193 & 64 & 70 & 6 & 0 & 198 & 334 & 575 & 763 & 950 & 1.360 & 43,16 \\
\hline Eldorado & 555 & 906 & 45 & 162 & 1 & 0 & 138 & 271 & 520 & 628 & 1.259 & 1.967 & 56,24 \\
\hline Iguape & 212 & 188 & 112 & 234 & 3 & 42 & 394 & 688 & 1.068 & 1.297 & 1.789 & 2.449 & 36,89 \\
\hline Ilha Comprida & 7 & 0 & 14 & 0 & 14 & 18 & 84 & 298 & 684 & 1.078 & 803 & 1.394 & 73,6 \\
\hline Iporanga & 1 & 26 & 7 & 15 & 0 & 0 & 379 & 40 & 346 & 413 & 733 & 494 & $-32,61$ \\
\hline Itaóca & 2 & 18 & 13 & 0 & 0 & 0 & 1 & 28 & 181 & 197 & 197 & 243 & 23,35 \\
\hline Itapirapuã Paulista & 20 & 162 & 0 & 0 & 0 & 0 & 1 & 54 & 169 & 246 & 190 & 462 & 143,16 \\
\hline Itariri & 282 & 261 & 74 & 78 & 89 & 0 & 178 & 347 & 428 & 533 & 1.051 & 1.219 & 15,98 \\
\hline Jacupiranga & 630 & 905 & 181 & 298 & 5 & 8 & 387 & 648 & 786 & 1.639 & 1.989 & 3.498 & 75,87 \\
\hline Juquiá & 722 & 573 & 174 & 300 & 13 & 48 & 207 & 456 & 749 & 938 & 1.865 & 2.315 & 24,13 \\
\hline Juquitiba & 23 & 37 & 1.680 & 434 & 121 & 124 & 902 & 1.245 & 8.714 & 4.657 & 11.440 & 6.497 & $-43,21$ \\
\hline Miracatu & 563 & 704 & 141 & 213 & 1 & 12 & 466 & 663 & 624 & 1.171 & 1.795 & 2.763 & 53,93 \\
\hline Pariquera-Açu & 290 & 534 & 289 & 194 & 8 & 421 & 575 & 1.116 & 1.098 & 2.079 & 2.260 & 4.344 & 92,21 \\
\hline Pedro de Toledo & 88 & 45 & 62 & 27 & 0 & 0 & 119 & 267 & 24 & 504 & 293 & 843 & 187,71 \\
\hline Peruíbe & 69 & 56 & 162 & 220 & 87 & 323 & 1.599 & 3.205 & 1.701 & 4.269 & 3.618 & 8.073 & 123,13 \\
\hline Registro & 952 & 1.133 & 661 & 1.547 & 259 & 749 & 2.187 & 3.849 & 2.933 & 5.879 & 6.992 & 13.157 & 88,17 \\
\hline Ribeira & 58 & 151 & 23 & 120 & 1 & 0 & 25 & 36 & 152 & 199 & 259 & 506 & 95,37 \\
\hline Ribeirão Branco & 1.135 & 1.702 & 214 & 134 & 0 & 22 & 103 & 344 & 674 & 895 & 2.126 & 3.097 & 45,67 \\
\hline São Lourenço da Serra & 56 & 93 & 385 & 457 & 54 & 99 & 1.188 & 604 & 212 & 188 & 1.895 & 1.441 & $-23,96$ \\
\hline Sete Barras & 555 & 861 & 68 & 93 & 0 & 20 & 87 & 235 & 403 & 509 & 1.113 & 1.718 & 54,36 \\
\hline Tapiraí & 152 & 130 & 207 & 358 & 6 & 61 & 161 & 124 & 339 & 411 & 865 & 1.084 & 25,32 \\
\hline Região & 8.260 & 11.142 & 5.733 & 6.337 & 828 & 3.259 & 10.432 & 16.869 & 25.397 & 32.790 & 50.650 & 70.397 & 38,99 \\
\hline Estado & 315.804 & 350.444 & 1.973.231 & 2.798.235 & 292.507 & 720.729 & 1.476 .745 & 2.681.646 & 4.549 .761 & 7.232.487 & 8.608.048 & 13.783 .541 & 60,12 \\
\hline
\end{tabular}

Fonte: SEADE, 2014. Organizado pelo autor. 
Ao olhar o quadro econômico geral, percebe-se a força do setor de serviços para compor o Produto Interno Bruto da região (PIB), seguindo a tendência do Estado. Porém, a diferença neste quesito está na agricultura, com uma média de aproximadamente $13 \%$ do peso da economia, bem acima do Estado. Alguns municípios como Eldorado, Sete Barras e Miracatu, que ainda mantém por volta de 30\% valor adicionado. A única exceção é Cajati, onde $35 \%$ das riquezas geradas no município provêm da indústria.

Tabela 5.7 - Participação dos setores em relação ao total do valor adicionado (\%) (2011)

\begin{tabular}{lccc}
\hline \multicolumn{1}{c}{ Município } & Agropecuária & Indústra & Serviços \\
\hline Apiaí & 11,52 & 24,09 & 64,39 \\
Barra do Chapéu & 16,51 & 12,68 & 70,82 \\
\hline Barra do Turvo & 4,93 & 11,76 & 83,32 \\
Cajati & 15,66 & 35,12 & 49,22 \\
Cananéia & 15,92 & 11,03 & 73,06 \\
Eldorado & 29,42 & 8,32 & 62,26 \\
Iguape & 13,82 & 10,71 & 75,46 \\
Ilha Comprida & 1,28 & 12,11 & 86,62 \\
Iporanga & 4,08 & 12,27 & 83,65 \\
Itaóca & 14,76 & 12,62 & 72,62 \\
\hline Itapirapuã Paulista & 11,73 & 16,74 & 71,54 \\
Itariri & 14,81 & 12,19 & 73,00 \\
Jacupiranga & 18,69 & 9,13 & 72,18 \\
Juquiá & 15,31 & 11,93 & 72,76 \\
Juquitiba & 0,14 & 19,63 & 80,23 \\
Miracatu & 29,00 & 8,21 & 62,78 \\
\hline Pariquera-Açu & 9,98 & 15,90 & 74,12 \\
Pedro de Toledo & 15,38 & 11,51 & 73,12 \\
\hline Peruíbe & 1,92 & 13,96 & 84,11 \\
Registro & 5,33 & 10,81 & 83,86 \\
\hline Ribeira & 11,13 & 11,21 & 77,66 \\
Ribeirão Branco & 14,75 & 10,78 & 74,47 \\
\hline São Lourenço da Serra & 1,48 & 18,42 & 80,10 \\
Sete Barras & 33,54 & 8,53 & 57,93 \\
\hline Tapiraí & 8,42 & 21,07 & 70,51 \\
\hline Região & 12,78 & 14,03 & 70,46 \\
\hline Estado & 2,11 & 27,43 & \\
\hline
\end{tabular}

Fonte: SEADE, 2014. Organizado pelo autor.

Os dados esboçados acima ilustram a tendência de diversificação na estrutura econômica do Vale do Ribeira (COELHO et al., 2005; FAVARETO; SCHORDER, 2007). No setor de serviços houve um importante aumento nas atividades de ecoturismo e o turismo rural, nos municípios de Cananéia, Ilha Comprida, Iguape, Peruíbe, Iporanga e Eldorado. Nos 
municípios litorâneos há instâncias turísticas e a consolidação de residências de lazer, enquanto nos municípios do alto vale há visitações às cavernas, hospedagens rurais e turismo de base comunitária organizada por comunidades quilombolas ${ }^{26}$ (SÃO PAULO, 2012, CHABARIBERY et al., 2006). Adicionalmente, vale destacar os serviços de saúde pública em Pariquera-Açu e o crescimento dos serviços públicos na região (SÃO PAULO, 2012).

No setor agrícola, a bananicultura ainda mantém um papel fundamental, principalmente nos municípios de Cajati, Eldorado, Itariri, Jacupiranga, Juquiá, Miracatu, Pedro de Toledo e Registro (MDA, 2010). Estes são municípios que detém uma agricultura familiar com baixa modernização, cuja produção é destinada em sua maior parte para as regiões metropolitanas de São Paulo e de Santos. (SPDR, 2012).

Porém, observa-se recentemente uma queda na área ocupada pela bananicultura, segundo o relatório de caracterização socioeconômica da Região Administrativa de Registro $^{27}$, elaborado pela Secretaria Estadual de Planejamento e Desenvolvimento Regional. O relatório mostra que entre 1995/1996 e 2007/2008 houve uma redução de 41,6 mil hectares para 36 mil hectares de bananais. Ainda assim, a produção da banana respondia a quase $10 \%$ do PIB regional até 2009 e a 80\% do Valor da Produção Agropecuária da região (MDA, 2011; SÃO PAULO, 2012).

A tradicional cultura do chá também vem perdendo espaço de área plantada. Contudo, importante ressaltar que a área total ocupada com atividades agropecuárias aumentou em $8 \%$ entre 1995/1996 e 2007/2008 28 . Há a consolidação da floricultura em Pariquera-Açu, que ocupa $43 \%$ da área Estadual, além da bovinocultura de corte que representou 30\% do total de cabeças do estado, sendo Eldorado o principal município de desenvolvimento desta atividade. Além disto, há a expansão do palmito pupunha, variedade de fácil adaptação na região que está substituindo a exploração do palmito juçara (SPDR, 2012). Há também o crescimento da fruticultura, com o plantio de maracujá, goiaba, abacate e tomate (MDA, 2011).

Outro grupo de atividade econômica na região é a pesca e aquicultura. Devido ao privilégio de possuir tanto a extensão litorânea como diversos rios, a atividades de pesca e aquicultura é difundida pela maior parte dos municípios da região, com uma movimentação de mais de $\mathrm{R} \$ 2.500 .000,00$ somente em 2006 (MDA, 2011).

\footnotetext{
${ }^{26}$ Circuito Quilombola. Disponível em: <http://www.circuitoquilombola.org.br/>. Acesso em 15 jan. 2015

${ }^{27}$ A Região Administrativa de Registro é a unidade regional de ação pública por parte do Governo do Estado de São Paulo, formada pelos municípios de Barra do Turvo, Cajati, Cananéia, Eldorado, Iguape, Ilha Comprida, Itariri, Jacupiranga, Juquiá, Miracatu, Pariquera-Açu, Pedro de Toledo Registro e Sete Barras, compreendendo uma área de $12.129 \mathrm{~km}^{2}$.

${ }^{28}$ Segundo o LUPA, a área total compreende: área com cultura perene, área com cultura temporária, área com pastagem, área com reflorestamento, área de vegetação natural, área com descanso ou pousio, área de vegetação de brejo e várzea.
} 
Há também experiências inovadoras de produção orgânica de alimentos. Os exemplos mais consolidados, podemos mencionar a Associação dos Agricultores Agroflorestais de Barra do Turvo/SP e Adrianópolis/PR - COOPERAFLORESTA, que trabalha com a produção agroecológica e agregação de valor com a produção de doces e a Associação Quilombo Ivaporunduva, localizado em Eldorado, que produz banana orgânica. Além disso, nas duas últimas décadas houve uma verdadeira proliferação de associações e cooperativas na região, muito como resultado dos conflitos ambientais por um lado, e pela necessidade de organização para reivindicação dos direitos de propriedade e de melhores condições para a produção agropecuária.

Um dos fatores determinantes para o estímulo ao crescimento de organizações de produtores em torno de associações e cooperativas está relacionado ao surgimento dos mercados institucionais, em especial o Programa e Aquisição de Alimentos - PAA (SABOURIN, 2007). Uma breve consulta no portal de transparência da Companhia Nacional de Abastecimento (CONAB) ${ }^{29}$ mostra que entre 2010 e 2014, a modalidade Doação, que repassa os produtos dos agricultores para instituições públicas, movimentou mais de vinte e dois milhões de reais, comprando produtos de associações e cooperativas de 14 municípios do Vale do Ribeira, como disposto na Tabela 5.8.

\footnotetext{
${ }^{29}$ CONAB. Transparência pública do PAA. Disponível em: $<$ http://www.conab.gov.br/detalhe.php?a=1296\&t=2>. Acesso em 19 nov. 2014.
} 
Tabela 5.8 - Entidades do Território Vale do Ribeira participantes da modalidade CPR Doação/PAA entre 2010 e 2014

\begin{tabular}{|c|c|c|}
\hline Município & Entidade & Valores $(\mathbf{R} \$)$ \\
\hline \multirow[t]{4}{*}{ Apiaí } & Cooperativa Agroindustrial do Alto Vale do Ribeira & $1.265 .060,00$ \\
\hline & Associação de Produtores Agroecológicos da Mata Atlântica do Vale do Ribeira - ECOOVALE & $1.450 .210,00$ \\
\hline & Associação dos Produtores Rurais do Distrito de Araçatuba - APRODA & $954.670,00$ \\
\hline & Associaçaõ dos Produtores Rurais de Lajeado & $234.350,00$ \\
\hline \multirow[t]{3}{*}{ Barra do Turvo } & Associação dos Agricultores Agroflorestais de Barra do Turvo, Adrianópolis e Bocaíva do Sul- COOPERAFLORESTA & $785.978,29$ \\
\hline & Associação dos remanescentes de Quilombo dos Bairros Ribeirão Grande e Terra Seca & $576.690,00$ \\
\hline & Associação Quilombola Pedra Petra e Paraíso & $954.800,00$ \\
\hline Cajati & Associação dos Agricultores Familiares do Município de Cajati - AAGFAM & $518.880,00$ \\
\hline \multirow[t]{2}{*}{ Eldorado } & Associação Quilombo de Ivaporunduva & $1.340 .457,97$ \\
\hline & Cooperativa dos Agricultores Familiares Quilombolas do Vale do Ribeira - COOPERQUIVALE & $1.079 .000,00$ \\
\hline Iguape & Associação Amigos e Moradores dos Bairros Arataca e Capoava do Monuma - AAMBACM & $499.540,95$ \\
\hline Iporanga & Cooperativa Agroindustrial Solidária & $122.670,00$ \\
\hline Itapirapuã Paulista & Associação dos Produtores Rurais do Município de Itapirapuã Paulista & $71.496,00$ \\
\hline Juquiá & Cooperativa dos Produtores Rurais e da Agricultura Famiiar do Município de Juquiá - COOPAFARGA & $2.416 .700,00$ \\
\hline \multirow[t]{2}{*}{ Miracatu } & Cooperativa Agroecológica de Vista Grande - COOPMAVIG & $698.369,40$ \\
\hline & Associação de Bananicultores do municípiode Miracatu - ABAM & $2.444 .130,00$ \\
\hline Pariquera-Açu & Associação dos Agricultores Familiares de Pariquera-Açu - AGRIFAPA & $173.600,00$ \\
\hline Pedro de Toledo & Associação dos Empresários Rurais de Pedro de Toledo & $142.080,00$ \\
\hline \multirow[t]{3}{*}{ Peruíbe } & Instituto dos Trabalhadores na Transformação da Agricultura Familiar - ITTAF & $578.014,83$ \\
\hline & Núcleo Rural de Peruíbe & $573.373,10$ \\
\hline & Associação dos Produtores Rurais da Microbacia Ribeirão das Panelas e Cossoca de Peruíbe & $736.970,00$ \\
\hline Registro & Cooperativa Agroecológica dos Agricultores Familiares do Vale do Ribeira e Litoral Sul - COOPERATIVA FAMILIA DO VALE & $4.229 .018,30$ \\
\hline \multirow[t]{2}{*}{ Sete Barras } & Cooperativa Agropecuária de Produtos Sustentáveis do Guapiruvu - COOPERAGUA & $93.060,00$ \\
\hline & Cooperativa da Agricultura Familiar de Sete Barras - COOPFASB & $260.400,00$ \\
\hline Total Território & & $22.199 .518,84$ \\
\hline
\end{tabular}

Fonte: CONAB, 2014. Organizado pelo autor. 
Apesar destas experiências positivas, o território Vale do Ribeira não mostra níveis de desenvolvimento que sejam comparáveis a média das outras regiões paulista. A Região Administrativa de Registro participou com apenas $0,28 \%{ }^{30}$ do PIB do estado, como mostra a tabela 5.4 abaixo.

\begin{tabular}{lrl}
\hline Tabela 5.9 - Produto e Renda PIB em milhões de reais correntes (2012) \\
\hline Região Metropolitana de São Paulo & $786.499,86$ & 55,8235 \\
Região Administrativa de Regis tro & $\mathbf{3 . 9 6 1 , 5 7}$ & $\mathbf{0 , 2 8 1 1 8}$ \\
Região Administrativa de Santos & $60.076,05$ & 4,26403 \\
Região Administrativa de São José dos Campos & $65.644,36$ & 4,65925 \\
Região Administrativa de Sorocaba & $68.402,17$ & 4,85499 \\
Região Administrativa de Campinas & $224.742,21$ & 15,9516 \\
Região Administrativa de Ribeirão Preto & $35.435,25$ & 2,51509 \\
Região Administrativa de Bauru & $24.245,64$ & 1,72089 \\
Região Administrativa de São José do Rio Preto & $33.370,28$ & 2,36853 \\
Região Administrativa de Araçatuba & $17.460,71$ & 1,23931 \\
Região Administrativa de Presidente Prudente & $16.568,09$ & 1,17596 \\
Região Administrativa de Marília & $20.867,63$ & 1,48113 \\
Região Administrativa Central & $25.806,04$ & 1,83164 \\
Região Administrativa de Barretos & $10.747,61$ & 0,76283 \\
Região Administrativa de Franca & $15.076,40$ & 1,07008 \\
\hline Total & $1.408 .903,87$ & \\
\hline
\end{tabular}

Fonte: SEADE, 2014. Organizado pelo autor.

Além disto, o aumento do emprego de da renda não se dão de forma uniforme no território Vale do Ribeira. A porção mais dinâmica do Vale esta no médio vale e no litoral. Os municípios de Barra do Chapéu, Iporanga, Itaóca, Itapirapuã Paulista, Ribeira, Ribeirão Branco e Barra do Turvo, estão localizados no alto vale, que é a porção com cerca de $95 \%$ das áreas contidas em UCs, restringindo as atividades agrícolas, apesar desta ser a principal atividade de geração de renda e emprego para as comunidades locais. A agricultura é predominantemente familiar, tendo arroz, milho, feijão e tomate como cultivares, com baixo uso de tecnologias agrícolas (CHABARIBERY et al., 2006).

\footnotetext{
${ }^{30}$ Para se ter uma noção abismo entre valores, no ano de 2012, o Município de São Paulo gerou um PIB de aproximadamente 500 bilhões de reais, pouco mais que 30\% do PIB Estadual, aproximadamente $10 \%$ do PIB brasileiro, e algo próximo a um valor 170 vezes maior que os 14 municípios mais dinâmicos do Vale, representados pela RA de Registro. Se adicionássemos os outros nove municípios que compõe o TCVR este valor pouco mudaria.
} 
Mesmo os municípios mais desenvolvidos do Vale já sentem as marcas da degradação ambiental e social causados pelo desenvolvimento promovido com a ausência de planejamento. A cidade de Registro, já sofre com os problemas do processo de urbanização sem planejamento, gerando cada vez mais núcleos periféricos motivados pelo grande número de pessoas que saem das cidades mais próximas a procura de emprego e melhor qualidade de vida. Por outro lado, Cajati é uma das cidades de maior intensidade na degradação ambiental, justamente pelo parque industrial de produção de cimento, cal, fertilizante e insumos para ração animal. Ainda há a exploração de areia ao longo de grande parte do Rio Ribeira de Iguape, que causa sérios danos ambientais às margens do rio, além do assoreamento em vários trechos, dificultando ou impedindo a navegação (FRANÇA, 2005).

Outra questão regional importante relaciona0-se com o quadro dos direitos de propriedade. Segundo o ITESP (2000) aproximadamente $40 \%$ do Vale prescindia de discriminação das terras. Até o momento, esta é a região de maior problema de legitimação de posse do Estado de São Paulo (CHABARIBEY et al., 2006). Resende (2002) afirma que o quadro fundiário do Vale do Ribeira é de indefinição de titulação de terras, sendo que a maior parte afetada por tal situação são os agricultores familiares por não possuírem documentação adequada. Por outro lado, a agricultora patronal ocorre em áreas já tituladas, ou cuja posse não é questionada devido ao prestígio econômico e político dos fazendeiros.

A fragilidade da questão fundiária afeta os moradores tradicionais, já que além destas comunidades não terem o direito a terra, ainda sofrem com as restrições da legislação ambiental. A situação de restrição ambiental ligada à fragilidade dos direitos de propriedade age como um dos principais fatores de impedimento ao desenvolvimento da região e de pressão ao uso inadequado dos recursos naturais. A regularização fundiária permitiria o agricultor familiar sair da condição de posseiro, o que permitiria o acesso a crédito agrícola e a inserção de boa parcela da população no processo produtivo, geraria empregos e reduziria os conflitos socioambientais e a exploração irracional da biodiversidade da Mata Atlântica (CHABARIBERY et al., 2006). Segundo Resende (2002, p.76):

\footnotetext{
"Os agricultores familiares tendem a se concentrar em áreas mais acidentadas, que em geral não têm titularidade definida e que possuem vegetação nativa, o que implica em problemas com o licenciamento, com falta de crédito, conflitos, dificuldades no transporte, definindo um quadro de extrema desvantagem e que implica quase que apenas na subsistência do agricultor".
}

Podemos ilustrar tal conflito com um exemplo obtido da entrevista realizada com o técnico da Casa de Agricultura de Eldorado. Em abril de 2014 ocorreu o processo de mudança dos perímetros do Parque Estadual do Jacupiranga, alterado pela Lei Estadual $n^{0} 12.810$ de 
fevereiro de 2008. As alterações foram realizadas e incluíram áreas de pastagem do bairro Barra do Braço, região esta que contém áreas com produção de gado de corte. Os pecuaristas só ficaram sabendo que estavam dentro dos novos limites do parque porque logo depois da alteração os mesmos foram multados pela polícia florestal. Segundo o técnico entrevistado, o conflito entre os criadores de gado e os órgãos ambientais prejudicam o acompanhamento do rebanho por parte dos agentes municipais, pois os pecuaristas, por medo de represálias, acabam não levando o gado para inspeção e vacinação, sob o risco de prejuízo para os próprios produtores. O agravante, é que atualmente Eldorado é principal município com atividades de bovinocultura da região, e a ausência de assistência técnica remete a um alto risco de proliferação de doenças veterinárias.

Os pequenos bananicultores do Vale do Ribeira provavelmente são os que mais sofrem as contingências negativas de subdesenvolvimento da região atualmente. Eles estão imersos num ciclo de subordinação aos atravessadores e aos grandes mercados regionais. Segundo França (2005), a monocultura de banana produz uma variedade de baixo valor agregado e dependente do mercado consumidor regional. Além disto, a banana envolve várias etapas, desde o preparo da terra, plantio e limpeza dos bananais, corte do produto nos sítios, transporte das bananas do sítio para os barracões das cidades próximas para limpeza e armazenagem, e por final o transporte do produto. Entre essas etapas estão os atravessadores, que acabam por ficar com a maior parte dos lucros. Além disto, esses atravessadores estão ligados, por exemplo, aos CEASAS e grandes supermercados das metrópoles (FRANÇA, 2005, p. 161).

Os bananais dependem de extensa mão-de-obra. As propriedades pequenas não conseguem trazer renda a todos os familiares que por consequência são forçados a se desagregarem, geralmente procurando empregos de diaristas nas fazendas maiores. E como há excesso de mão-de-obra com baixa qualificação, os salários (ou diárias) pagos são irrisórios. Já os jovens, por não ter opção de educação de qualidade e de trabalho qualificado, acabam muitas vezes por arrumarem emprego em outra cidade (FRANÇA, 2005).

Ademais, o autor afirma que há um controle político das cooperativas por parte dos grandes bananicultores:

“O problema está relacionado ao conflito de interesses entre os grandes produtores e os demais produtores (de banana), visto que na época dos preços altos para venda, os grandes bananicultores deixam de lado os interesses da cooperativa e passam a atuar isoladamente no mercado e, na má temporada de preços, quando do excesso de oferta de bananas, os grandes produtores exigem maior espaço para os seus produtos, que passam a ser comercializados pela cooperativa, inviabilizando a existência da cooperativa para os produtores de bananas do Vale do Ribeira" (FRANÇA, p. 158). 
Ademais em comparação as outras regiões, à produtividade da banana no Vale é baixa, e perde em competitividade para outras regiões, como Santa Catarina, norte de Minas e Nordeste. Países como Equador também estão investindo no produto. Todos os exemplos citados são experiências que adotaram técnicas mais modernas de produção, pós-colheita e comercialização $^{31}$ (RESENDE, 2002). Segundo França (2005):

\begin{abstract}
"Quando comparamos os índices de produtividade de banana entre os próprios municípios do Vale do Ribeira ou com outros municípios do Estado, percebe-se que a produtividade alcançada no Vale do Ribeira está baixa e bem próxima da média estadual. Isso ocorre em razão do Grande abandono dos bananais da região, em decorrência da presença de doenças, entre as quais a sigatoka negra, e, também, pelo alto custo dos insumos e defensivos agrícolas necessários para a manutenção desses bananais, cuja exaustão da terra está evidente em alguns municípios em razão da não rotatividade agrícola". (FRANÇA, p.164)
\end{abstract}

Para o autor, há dois problemas estruturantes no Vale do Ribeira: i) as relações historicamente assimétricas dos políticos da região, dada a baixa capacitação e conhecimento de direitos por parte dos cidadãos, fator este promotor de relações clientelistas, e ii) o histórico de pífios investimentos por parte do governo estadual na região. Os dados do autor referente a 2001 mostram que a Região Administrativa de Registro recebeu apenas $0,76 \%$ das transferências de recursos repassados pela União e Estado (FRANÇA, 2005, p. 176). Certamente não há necessidade de buscar informações na Fundação SEADE ou no Tesouro Nacional para saber que este volume de verbas não aumentou significativamente até o momento atual.

Os dois pontos estão relacionados, pois a ausência de inversão pública por parte do Estado e União a região se mantém impedida de promover investimentos voltados a melhoria e diversificação da produção agrícola. Os municípios em sua maioria não possuem receita própria, pois não produzem produtos com valor agregado que possam gerar e recolher tributos próprios. O círculo vicioso se fecha nas relações clientelistas entre prefeituras e governos subnacionais e nacionais, pois na ausência de recursos, os prefeitos acabam por se submeter aos ditames dos governos e passam a buscar recursos públicos para o atendimento das suas demandas. Além disto, o gasto público no âmbito municipal não possui qualquer tipo de controle, o que acarreta em gastos desmesurados e falta de qualquer componente ético no legislativo municipal, pois as contas públicas são aprovadas, mesmo que elas sejam rejeitadas

\footnotetext{
${ }^{31} \mathrm{O}$ ápice desta ameaça se materializou em 2013, quando o governo brasileiro acordava com o governo equatoriano a importação de banana deste último. A tratativa entre os países gerou forte reação dos agricultores patronais, o que levou o governo brasileiro a revogar a medida em maio de 2014.
} 
pelo Tribunal de Contas do Estado. Isso reforça as relações clientelistas entre prefeituras e governo estadual $^{32}$ (FRANÇA, 2005).

Por outro lado, não há incentivos aos atores privados que queiram apostar seu investimento na construção de empresas e agroindústrias numa região com pouca infraestrutura e capacitação da maior parte dos seus cidadãos (FRANÇA, 2005; FAVARETO; SCHRORDER, 2007). É neste sentido que se observa um paradoxo. França (2005) ressalta que a região possui diversos atributos que são originários dos distritos industriais: o território se encontra entre os dois dos Estados mais ricos do país; o território está a menos de 200 quilômetros de cinco das 67 Regiões Metropolitanas brasileiras, São Paulo, Campinas, Santos e Curitiba e Sorocaba ${ }^{33}$, além de estar entre os dois dos principais nós de exportação dos produtos brasileiros, o Porto de Santos e do Porto de Paranaguá, em São Paulo e Paraná, respectivamente. Aliado aos atributos naturais e a riqueza sociocultural, o autor deixa claro que o Vale do Ribeira tem um dos maiores potenciais para construção de um modelo de desenvolvimento sustentável. Isso só não ocorre por causa das condicionantes e conflitos brevemente esboçados acima (FRANÇA, 2005).

Após esta breve caracterização, percebe-se que mesmo com a difusão de experiências exitosas de desenvolvimento social e econômico a nível local, a economia do Território Vale do Ribeira ainda se assenta na produção agrícola de variedades com baixo valor agregado e na extração de produtos da Mata Atlântica. Apesar do esforço, há poucas variedades exploradas na região, e destas, poucas são comercializadas além do nível regional. Desta forma, a contextualização do Vale do Ribeira nos leva a recuperar brevemente como se deu a ocupação e a ação do Estado na região. Assim, compreenderemos melhor quais foram os condicionantes históricos que moldaram as relações sociais, econômicas e ambientais na região.

\subsection{A colonização e os ciclos econômicos}

O município de Cananéia foi um dos primeiros locais de chegada e ocupação dos europeus no Brasil no século XVI. Pela abundância de alimentos disponíveis, os colonos

32 Felizmente, a organização dos cidadãos brasileiros forçaram a criação da lei da ficha limpa (Lei Complementar n0 135, de 4 de julho de 2010) e a lei da transparência (Lei n0 12.527, de 18 de novembro de 2011). A primeira lei objetiva deixar inelegível a pleitos executivos e legislativos os candidatos com mandato cassado ou que sejam condenados por decisão do judiciário. Já a lei da transparência obriga a todos os órgãos públicos a divulgarem todas as informações na internet para que todos os cidadãos tenham acesso. Houve uma grande transformação na gestão pública desde então, pois agora os cidadãos tem acesso aos recursos disponibilizados. Entretanto, ainda se mantém a dificuldade de saber como esses recursos são utilizados.

${ }^{33}$ As Regiões metropolitanas em questão somam mais de 28 milhões de cidadãos. Incluindo a Região Metropolitana de Osasco, elevada recentemente a tal categoria, a população total somaria mais de 30 milhões de pessoas (IPARDES, 2014; SEADE, 2014). 
adotaram rapidamente o modo de vida indígena, vivendo de coleta e plantio de subsistência (DEAN, 1996). No início do século XVII as expedições de exploração do interior descobriram bolsões de aluviões auríferos Rio Ribeira de Iguape acima. Assim, inicia-se o ciclo do ouro (PETRONE, 1966).

O ciclo do ouro consolidou as primeiras ocupações no interior do Vale, principalmente na região de Xiririca, atual município de Eldorado (MUNARI, 2009; PETRONI, 1966). O ciclo durou praticamente todo o século XVII, decaindo no século seguinte pela redução dos filões auríferos e a migração maciça dos indivíduos para as Minas Gerais. A cidade de Iguape, por estar localizada na foz do Rio Ribeira e controlar a logística de transporte da extração, concentrou a maior parte da riqueza gerada pela exploração do ouro e acabou se tornando o centro de comércio da região. Sem opção, as comunidades do interior voltaram para as atividades de subsistência, muitas vezes afastadas dos bairros e do Rio Ribeira (BRAGA, 1998).

Houveram ciclos econômicos localizados: um de construção naval em Iguape, e outro a retomada da exploração aurífera de aluvião, desta vez em concentrado as explorações em Apiaí. O Alto Vale criou laços comerciais o planalto paulista a partir de Sorocaba, e foi desta região a principal fonte de ocupação das porções acima do Rio Ribeira (BRAGA, 1998).No início do século XIX surge o ciclo do arroz, beneficiado principalmente pela longa extensão de várzeas e planície inundadas ao longo do Rio Ribeira. O ciclo se desenvolveu ao longo da expansão do sistema escravista e teve o seu auge na primeira metade do século. No entanto, os benefícios deste ciclo se concentraram nas cidades portuárias devido ao controle de remessas a serem enviadas para Santos ou Rio de Janeiro, direcionadas a exportação e a comercialização regional (VALENTIN, 2006).

Na metade do século XIX o ciclo o arroz entra em decadência, em muito pela queda do comércio de escravos a partir da proibição do comércio escravista em 1850. Além disso, a concentração da renda nas mãos de poucos comerciantes e produtores com maior infraestrutura não permitiu uma distribuição maior da renda adquirida pelo ciclo do arroz (VALENTIN, 2006).

Neste mesmo ano a Lei de Terras é promulgada. Esta lei regulamentaria a transição do trabalho escravo para o trabalho livre, além de consolidar o controle estatal sobre a ocupação de terras devolutas ${ }^{34}$. Neste sentido, a lei confirmaria as posses existentes e demarcaria as

\footnotetext{
${ }^{34}$ Segundo o ITESP (2000: p.42-43) “Terra devoluta: é espécie de terra pública, visto que é aquela que em nenhum momento integrou o patrimônio particular, ainda que esteja irregularmente em posse de particulares. Em outras palavras, terra devoluta é terra pública, pelo fato de não haver esta ingressado no domínio particular".
} 
terras devolutas, para serem utilizadas posteriormente nos projetos de colonização. Contudo, houve grande resistência por parte dos fazendeiros em efetivar a legislação, bem como a ausência de esforço governamental para tal, o que permitiu a ação dos fazendeiros na posse da terra em detrimento do seu uso social por escravos recém-libertos e colonos livres. Como exceção os princípios da lei foram aplicados de forma contundente na região sul (RESENDE, 2002). Assim, o Vale do Ribeira constituiu o primeiro ciclo de disparidade social e pobreza no início de sua ocupação. Segundo Valentin (2006, p.202):

\begin{abstract}
“O perfil de riqueza observado na fase de disseminação do cultivo de arroz revela-se peculiar por retratar um momento de maiores oportunidades para a expansão da empresa escravista. A trajetória e alguns destes escravistas evidencia o enorme sucesso na adoção de estratégias que envolviam uma certa disponibilidade de recursos para a aquisição de escravos associada como estabelecimento de relações sociais que favoreceram o acesso à posse fundiária. Com a consolidação das novas práticas agrícolas, a reprodução das alianças familiares manteve-se como um dos mecanismos de concentração de renda entre a elite ribeirense. A manutenção da lavoura de arroz, entrementes, reduziu qualquer possibilidade de exploração de novos nichos econômicos e, impossibilitada de acompanhar o ritmo de crescimento de outras regiões paulistas que se especializavam no cultivo do café, tem-se como resultado final do arrefecimento da posse escrava".
\end{abstract}

Desta forma, a região perdeu importância como produtor e exportador de arroz quando houve o aumento de concorrência de outras regiões de São Paulo que iniciavam a produção da variedade $\mathrm{O}$ principal destino das sacas de arroz tinha no Rio Ribeira de Iguape a principal artéria de ligação entre o interior e o centro distribuidor da cidade de Iguape. Em 1827 é iniciado a abertura de um canal entre um dos meandros do Rio Ribeira e o Porto de iguape. A intenção era facilitar o transporte de arroz para o porto. O então Canal do Valo Grande é inaugurado em 1856, com uma largura de 22 metros. Contudo, as margens sofreram com o intenso assoreamento, causando um alargamento para mais de 200 metros e depositou toda a carga de sedimentos na desembocadura do mar pequeno. Já no início do século XX o Porto de Iguape não mais receberia navios de grande porte por causa do desastre ambiental ocorrido no Canal do Valo Grande (TODESDO, 2007; VALENTIN, 2006).

A

Situação antes da construção do Valo Grande

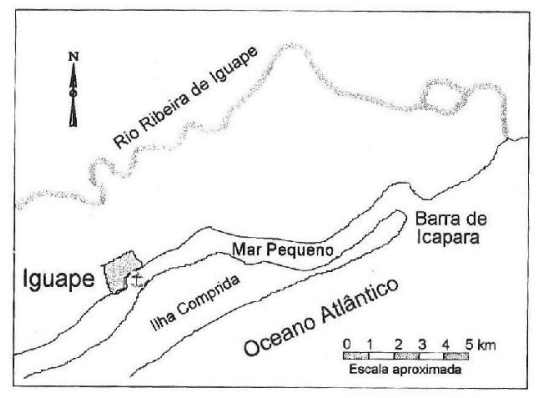

B

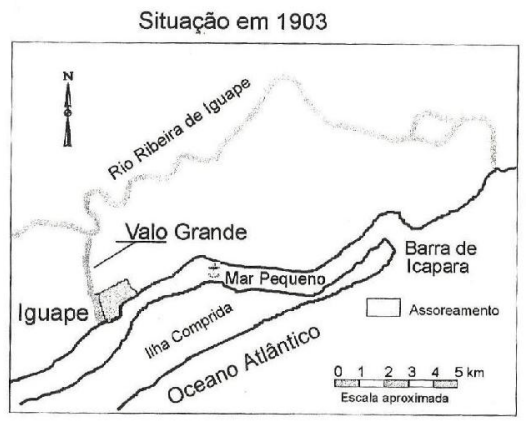

Figura 5.6 - Assoreamento do Mar Pequeno, Iguape. Fonte: Braga (1998, p. 71). 
O ciclo do café em expansão no planalto paulista foi determinante para o declínio do ciclo do arroz. A expansão do ciclo cafeeiro possibilitou o governo da época a estimular a importação de arroz no início da década de 1880, atingindo diretamente a região ribeirense. Já na década de 1890, o governo volta a taxar as importações de arroz, porém, neste meio tempo, outras regiões iniciaram o cultivo da variedade, como Rio Grande do Sul e Mato Grosso e Ribeirão Preto, além da retomada desta atividade produtiva no Maranhão. Logo, a conjunção de um novo ambiente competitivo em relação à produção do arroz, a difícil logística de escoamento da produção devido ao assoreamento do Valo Grande e o sistema escravista de produção da variedade são os fatores que determinam a queda do ciclo do arroz no Vale do Ribeira (VALENTIN, 2006).

O Vale ficou à margem o desenvolvimento levado à cabo pelo café no Planalto Paulista. Desta forma, a maior parte da população, à exceção de uma pequena elite que produzia arroz "por falta de opção" (VALENTIN, 2006, p. 16), volta-se para a agricultura de subsistência nas regiões mais afastadas e pouco exploradas a época, levando ao processo chamado de "caipirização" (BRAGA, 1998). Por um lado, o retorno as atividades de subsistência refletiam a estagnação econômica na qual o Vale se encontrava (MINARI, 2009). Por outro lado, o início do século XX consolidou a maior parte das comunidades tradicionais, além das comunidades indígenas que já habitavam o local (DEAN, 1996). Essas comunidades viviam fundamentadas nas formas compartilhadas de vivência, atividades de ajuda mútua e trabalho compartilhado da lida na terra e da caça, características bem próximas do modo de vida do caipira paulista (MUNARI, 2009; PEDROSO et al., 2008). Na época a distinção das comunidades do Vale do Ribeira era dada da seguinte forma: i) caiçaras: caboclos do litoral; ii) ribeirinhos: caboclos das margens dos rios e, iii) capuavas: caboclos das serras (QUEIROZ, 2006).

Apesar destas comunidades estarem afastadas geograficamente das áreas mais dinâmicas da região, elas mantinham relações comerciais externas, principalmente com pequenos comerciantes que transitavam ao longo do Rio Ribeira de Iguape. Haviam então duas situações: as variedades de subsistência que eram plantadas sob o sistema da agricultura itinerante $^{35}$ (feijão, milho, mandioca, café, hortaliças e legumes) e as atividades de criação de porco, complementando com a coleta e produtos da mata e a pesca; e a continuidade à plantação de arroz em áreas mais extensas já reservadas para tal, do qual surgia o principal

\footnotetext{
${ }^{35}$ Como não podemos fugir do nosso objeto de pesquisa, vamos apenas ressaltar que há uma relevante literatura que discute conceitualmente o sistema de agricultura itinerante e as suas implicações nas comunidades quilombolas do Vale do Ribeira. Para os leitores interessados, ver Adams e colaboradores (2013), Lima (2013) Munari (2009), Prado, (2012), Pedroso Jr. e colaboradores (2008) e Queiróz (2006).
} 
excedente de comercialização e troca por produtos que os quilombolas não conseguiam produzir, como sal, querosene e fósforo. Assim o ciclo do arroz foi continuado de forma dispersa e reproduzido pelas as comunidades mais afastadas do médio ribeira (MUNARI, 2009).

No início do século XX há um novo processo de colonização na região, sendo destacada a imigração japonesa. Diferente das outras investidas por parte das comunidades estrangeiras como americanos, alemães, italianos, poloneses, entre outros, a colonização nipônica na região foi fruto de um acordo assinado entre os governos do Brasil e do Japão. Em 1918 foi criada a K.K.K.K. (Kaigai Kogyo Kabushiki Kaisha), Companhia Ultramarina de Empreendimentos S. A., filial da Companhia Imperial Japonesa que se torna responsável pela colonização regional (PETRONE, 1966).

Esse processo surgia como uma primeira tentativa de quebrar o isolamento do Vale do Ribeira. A partir de 1930, o governo Getúlio Vargas repassa recursos para expansão das culturas perenes. Os repasses não duraram muito tempo, mas foram suficientes para iniciar a concentração de terras com a expansão da teicultura e da bananicultura (MUNARI, 2009). A colonização japonesa foi fundamental para recolocar a região a ritmos de desenvolvimento econômico a partir da produção de culturas perenes, além das obras de infraestrutura, iniciando a construção de estradas em direção ao planalto paulista. Segundo Braga (1998, p. 83):

\footnotetext{
"desse modo o eixo econômico do Vale do Ribeira, que, desde o século XVI, direcionava-se do interior para Iguape pelo rio Ribeira, transversalmente à costa, passa a correr paralelo ao litoral, de Registro para Juquiá e daí, por via férrea, para Santos. É nesse processo que Iguape perde a primazia na região cedendo seu lugar a Registro que se torna a nova "capital" do Vale do Ribeira".
}

Entretanto, a integração ao mercado se deu com variedades de baixo valor agregado, essencialmente alimentos de baixo custo. Em adição, o mercado de reservas de terra iniciaria de forma tímida (RESENDE, 2002, p. 69). A colonização e a relativa ascendência econômica ocorrida na primeira metade do século XX tão só se resumiu as regiões mais dinâmicas, notadamente a cidade de Registro e o seu entorno próximo. As comunidades remanescentes de escravos dispersas no Alto Vale ficaram excluídas deste momento de dinamização econômica (MARQUES, 2013).

Já na década de 1940 a região que se desenvolvia de forma intermitente atraia pessoas de fora interessadas nos diferentes potenciais de exploração do Vale do Ribeira. Uma das variedades de maior interesse de exploração era o palmito Juçara (Euterpe edulis). Em paralelo o crescimento do interesse e da extração efetiva do palmito, inúmeras fábricas de 
palmito em conserva foram implantadas no Vale do Ribeira. A exploração ocorria tanto em grandes propriedades como com a contratação das comunidades de pequenos posseiros, quilombolas, caiçaras e ribeirinhos para extração nas áreas próximas. Com a intensificação da atividade, há uma expressiva redução da espécie por um lado, e a transformação da reprodução sociocultural das comunidades, principalmente em relação ao desvio das atividades de subsistência. Este fenômeno inicia a primeira fase de dependência econômica dos quilombolas em relação aos compradores de palmito. Esta relação iniciaria diversas transformações no modo de vida destas comunidades ${ }^{36}$ (MUNARI, 2009; PEDROSO JR et al., 2008).

\subsection{A intervenção estatal}

Os governos da época intensificaram suas ações no Vale do Ribeira na segunda metade do século passado. A principal intervenção estatal nesta época foi à construção da Rodovia Regis Bittencourt. Esta Rodovia foi inaugurada no final da década de 1960 e ligava os municípios de São Paulo a Curitiba, integrando a Rodovia Federal BR-116, a qual ela é chamada comumente na região. Apesar do motivo principal da construção da rodovia ser a integração para o desenvolvimento industrial nacional promovido pelo governo Juscelino Kubitscheck (1956-1961), a BR-116 foi a maior indutora de alteração da infraestrutura e dinamização da economia regional (MUNARI, 2009; RESENDE, 2002).

O primeiro esboço de uma intervenção planejada partiu do Governo Carvalho Pinto (1959-1963) com o Plano de Ação. O plano fora construído por uma equipe próxima ao governo, e tinha o objetivo à "melhoria, aperfeiçoamento e atualização da atividade do Estado" (BRAGA, 1998, p. 86) para promoção do aumento da qualidade de vida da população e do desenvolvimento econômico. Assim o plano compreendia duas finalidades: i) investimento para a melhora das condições de vida do indivíduo (educação, cultura, pesquisa, justiça, segurança, saúde, assistência social e saneamento básico) e, ii) investimentos para a promoção do desenvolvimento (infraestrutura, energia elétrica, transportes e comunicações, fomento agropecuário e estímulo industrial) (BRAGA, 1998, p. 86).

\footnotetext{
36 Ver também o interessante estudo sobre a espécie. "Os segredos do Palmito". Disponível em: $<$ http://www.pick-upau.org.br/mundo/palmito_ecologico/palmito_jucara.htm>. Acesso em: 15 jan. 2015.
} 


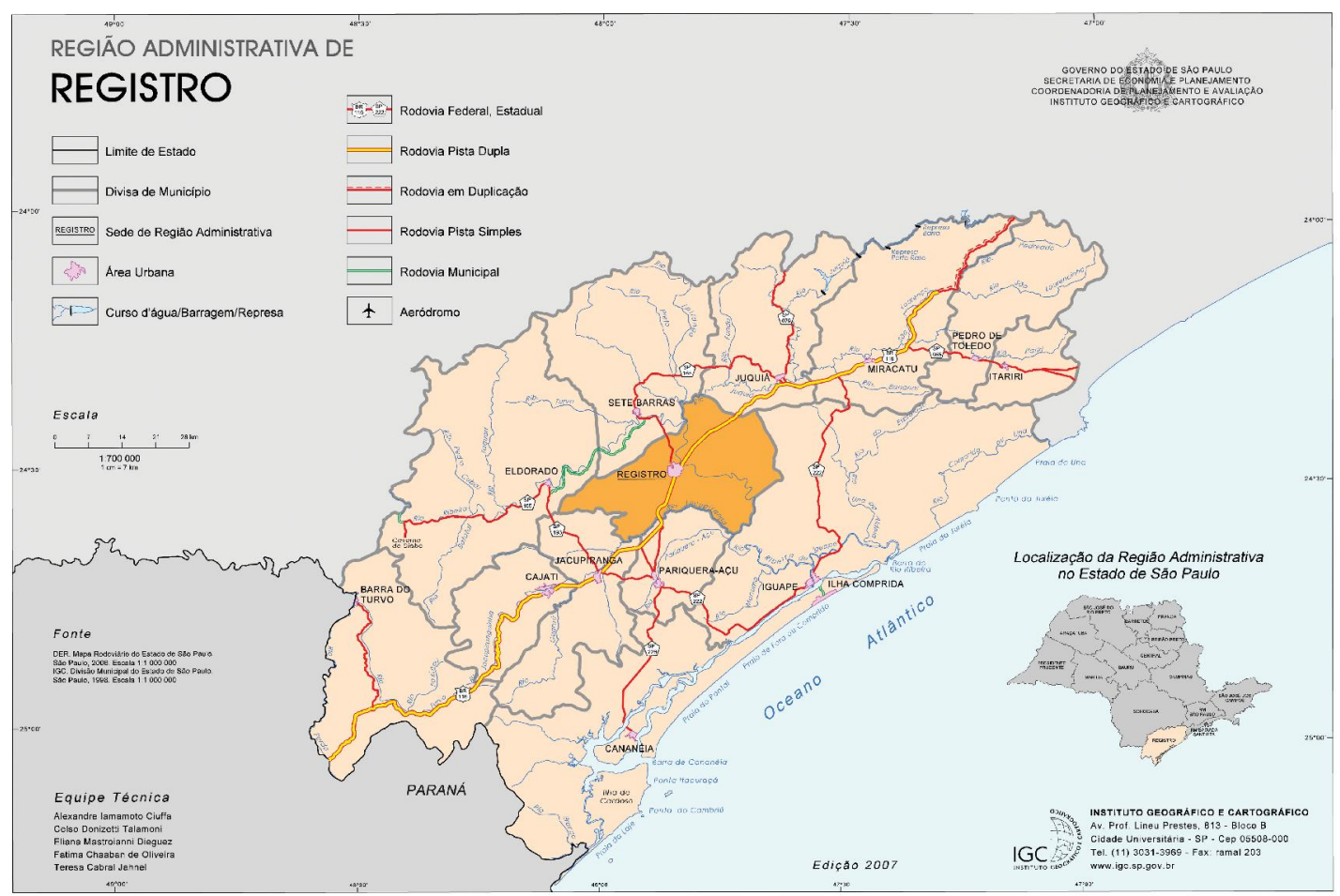

Figura 5.7 - Rodovia Régis Bittencourt - BR 116. Fonte: Instituto Geográfico e Cartográfico (IGC), (2007) ${ }^{37}$.

Apesar de não haver menção explícita ao Vale, o Plano de Ação foi a primeira tentativa de construção de uma intervenção planejada, com relativas possiblidades de sucesso. Do Plano de Ação, surge a primeira tentativa de ação sistemática visando o desenvolvimento da região, denominado "Operação Caiçara". Esta operação é iniciada com a resolução do governo anterior de Jânio Quadros (1961) em formar uma comissão de técnicos e representantes estatais (Comissão 1045), com o intuito de realizar estudos voltados a melhor compreensão da complexidade social e econômica do Vale (BRAGA, 1998). O então governador da época cria um decreto fundindo a Comissão 1045 com a Comissão do Litoral do Estado, com fins de aprofundar os estudos e criar diretrizes voltados ao desenvolvimento regional (BRAGA, 1999).

Em 1961, as duas comissões entregam um relatório ao governo estadual com o levantamento dos desafios e potencialidades da região, bem como a descrição de medidas necessárias ao desenvolvimento da mesma, a saber: Regime especial de trabalho; Programa Moradia para professores em zona rural; Fundo de Desenvolvimento do Vale do Ribeira; Companhia de Comércio e Navegação Sul Paulista; Assistência Hospitalar; Assistência Médico-Social às Ilhas do Litoral Norte; Assistência Médico-Social às populações rurais do

\footnotetext{
${ }^{37}$ Disponível em: <http://www.igc.sp.gov.br/produtos/mapas_ra.aspx?ra=0>. Acesso em: 15 jan. 2015.
} 
Litoral Sul; Turismo; Pesca; Agricultura e pecuária; Medidas de caráter educacional; Viação e, Financiamento agrícola e problema da terra (BRAGA, 1998).

As ações descritas no Plano de Ação não foram implementadas, porém destaca-se este momento como um marco por ser a primeira vez na qual o Estado se debruça sobre o Vale do Ribeira com o proposito de solução integrada dos problemas. Além disso, a Operação Caiçara foi a base de surgimento da Superintendência do Desenvolvimento do Litoral Paulista SUDELPA, ao propor pela primeira vez a criação de um fundo de desenvolvimento e de uma agência de desenvolvimento para o Vale do Ribeira (BRAGA, 1998).

O Governo Adhemar de Barros (1963-1966) primou pela agenda criada no Plano de Ação, elevando o Grupo de Planejamento à categoria de Secretaria de Planejamento, além da elaboração do Plano de Desenvolvimento Integrado - PLADI (1964-1969). Adhemar de Barros tinha a intenção de institucionalizar o planejamento estatal subsidiado e, apesar do PLADI ter sido considerado uma proposta melhorada do Plano de Ação, a sua elaboração foi realizada sem considerar o quadro orçamentário das secretarias e órgãos diretamente envolvidos, acarretando na não implementação deste plano (BRAGA, 1998).

O governo de Lauro Natel (1966-1967) determina a criação do Plano Global de Desenvolvimento do Vale do Ribeira e Litoral Sul. A elaboração deste plano ficou a cargo do Serviço do Vale do Ribeira (SVR), órgão vinculado ao Departamento de Águas e Energia Elétrica (DAEE), que contratou a BRASCONSULT - Engenheiros Projetistas e Consultorias Técnicas Administrativas S.C. Em 1966 o governador Natel recebe o documento intitulado Plano de Desenvolvimento do Vale do Ribeira e Litoral Sul. As ações se resumiram a pequenas obras de infraestruturas e a incidência de medidas assistencialistas, (BRAGA, 1998).

A entrada do governo Abreu Sodré (1967-1971) reforçou as ações do SVR nas áreas de infraestrutura e exploração de potenciais turísticos. Em 1969 cria a SUDELPA, entidade autárquica com o objetivo de possibilitar o desenvolvimento do Litoral através do Plano de Desenvolvimento do Litoral. Este plano tinha duas diretrizes principais: elaborar a política de desenvolvimento regional e criar a articulação dos demais órgãos públicos da região (BRAGA, 1998). A proposta de atuação da SUDELPA tomou base da experiência do "Tenesse Valey Autority", política desenvolvida nos EUA na década de 1930. A experiência decorreu do modelo de "desenvolvimento integrado de bacias hidrográficas", articulando obras de infraestrutura e hidroeletricidade com o desenvolvimento agropecuário de uma dada região (BRAGA, 1998). 
Contudo, as ações se traduziram em projetos locais de caráter pulverizado, reforçando as práticas clientelistas e assistencialistas. Houve um aumento da disparidade socioeconômica, já que as ações de infraestrutura beneficiaram as regiões mais dinâmicas e os maiores agricultores. A construção de estradas trouxe consigo a incidência de intermediários que compravam a baixos preços a produção excedente dos pequenos agricultores e das comunidades negras mais afastadas (QUEIRÓZ, 2006). As políticas de credito rural foram direcionadas aos maiores proprietários de terras, já que além do título, eles possuíam garantias que facilitavam a relação com os bancos. Por outro lado, a fragilidade jurídica na qual se encontrava os produtores mais pobres serviu como impeditivo de acesso ao crédito, concomitante com a preferência dos bancos em emprestar dinheiro aos proprietários mais ricos, pela redução do risco de inadimplência (RESENDE, 2002).

Os mandatos de Lauro Natel (1971-1975; 1975-1978) são considerados a fase áurea da SUDELPA (BRAGA, 1998), já que mais de $60 \%$ de todo o orçamento durante a história da autarquia foram implantados neste período. Entretanto, a maior parte deste montante segue o padrão dos exemplos acima, onde as obras de infraestruturas foram direcionadas às porções mais desenvolvidas do Vale. Um dos exemplos mais claros é a construção dos ramais de trem Juquiá-Cajati e Itararé-Apiaí, pela Ferrovia Paulista SA (FEPASA), visando o escoamento de produtos da indústria do cimento do grupo Serrana e do grupo Camargo Corrêa (TODESCO, 2007, p. 114). Estes ramais se ligariam ao ramal Santos - Cajati, que havia sido construída entre 1913 e 1915. Além disso, foram direcionados esforços no sentido de continuidade dos estudos e ações para promover o turismo, principalmente em Cananéia e Eldorado.

O Governo Paulo Salim Maluf (1979-1982) marca a fase negativa da autarquia. Como marca dos dois governos anteriores, implicações políticas entre a continuidade do desenvolvimento da superintendência pelo governo federal não era de interesse do então governante estadual. O reflexo desta tensão política foi à redução orçamentária da SUDELPA com a consequente interrupção das obras de infraestruturas e projetos de desenvolvimento da do Vale. As ações por parte da autarquia se viram novamente voltadas a pequenas obras, com ausência de planejamento e tratamento direto com as prefeituras, reforçando as práticas clientelistas (BRAGA, 1998). Esta quebra das ações estatais também promoveu o aumento de grileiros na região, com a intensificação dos conflitos entre as comunidades mais pobres, além do aumento da degradação ambiental, principalmente com a atividade extrativista (RESENDE, 2002).

Franco Montoro assume o governo em 1983 em meio a uma grande crise financeira. Este foi o primeiro governo eleito no período pós-autoritário com a proposta de gestão 
democrática e priorização das questões sociais e ambientais, incluindo o fortalecimento da SUDELPA (BRAGA, 1998). O governo lançou em 1985 o Plano Diretor do Desenvolvimento Agrícola do Vale do Ribeira, chamado MASTERPLAN. Diferente dos planos anteriores que orientavam esforços na infraestrutura, o MASTERPLAN foi o primeiro plano de desenvolvimento regional do Vale do Ribeira. Ele objetivava resolução de problemas dos pequenos agricultores da região, fundamentalmente a questão da posse irregular da terra, já que, não muito diferente do momento atual, a região possuía $40 \%$ das terras não possuíam situação dominial regularizada. Este fato dava amplas condições aos grileiros e intensificavam os conflitos violentos na região.

Há um importante fator a ser destacado durante o Governo Franco Montoro. Em primeiro lugar, este governo foi o primeiro que tentou tirar o pequeno agricultor/posseiro da invisibilidade na região. Sob ao guarda-chuva do MASTERPLAN, a primeira ação do governo foi criar o Centro de Desenvolvimento Agrícola do Vale do Ribeira (CEDAVAL). O órgão foi criado como braço operacional da Secretaria de Agricultura e Abastecimento (SAA) do governo estadual. Este órgão, criado por interesse do governo japonês de desenvolver a atividade agropecuária na região. Adicionalmente, uma das linhas do CEDAVAL seria a implantação do Projeto de Monitoria Agrícola, voltado aos agricultores familiares. Contudo, o projeto falhou por ter a proposta de investir maciçamente para promover uma agricultura sofisticada e moderna, sem levar em conta "as condições atípicas da região do Vale, dos pontos de vista socioeconômico, fundiário e ambiental" (IDESC, 2005, p. 17).

Outras ações realizadas ainda no governo direcionadas especificamente a agricultura familiar foi o Projeto Emergencial de Apoio à Pequena Agricultura (PEAPA), o Programa de Ação Comunitária do Vale do Ribeira (PACI-VR) e o Programa de Regularização Fundiária. Tanto o PEAPA como o PACI-VR foram descontinuados logo no seu início (IDESC, 2005). Já o Programa de Regularização Fundiária realizou diagnósticos e ações de mediação de conflito fundiário com os pequenos posseiros. Porém, o programa foi descontinuado com o término do governo Franco Montoro. Apesar da parcial implantação do MASTERPLAN, as ações orientadas ao desenvolvimento socioambiental levada a cabo pelo o governo Montoro foram suficientes para reduzir o quadro da disparidade social, porém, serviu para dificultar a prática de clientelismo entre prefeituras e governo do Estado, o que gerou forte reação contrária das prefeituras em relação à SUDELPA (BRAGA, 1998; RESENDE, 2002).

Com a entrada do governo Orestes Quércia (1987-1991), o tema que tratava sobre o fechamento da SUDELPA ganhou prioridade na agenda de governo, convergindo à bandeira dos prefeitos se viam com pouca margem de manobra em relação às práticas clientelistas 
combatidas pelo governo Franco Montoro, evidenciando, novamente, uma posição de ordem política (BRAGA, 1998). No momento em que há a troca de governo, os agricultores familiares simplesmente são esquecidos, já que todas às políticas direcionadas a esta categoria estavam sob o guarda-chuva da superintendência, agora extinta.

Em síntese, a fase de intervenção estatal até aqui brevemente abordado caracteriza-se por um estado de presença intermitente, que na maioria dos casos agravou os conflitos no Vale. Apesar do relativo crescimento econômico principalmente na década de 1970, a região passou por um aumento da concentração fundiária motivada pela valorização das terras. $\mathrm{O}$ conflito fundiário intensificado distanciou as comunidades pobres das áreas mais férteis e a incidência de grileiros e pessoas interessadas nos recursos naturais contribuiu para o aumento do desmatamento da região, principalmente a procura do palmito juçara e da caixeta (RESENDE, 2002).

Braga (1998, p. 186) conclui sobre a atuação do Estado na região da seguinte forma: “...podemos afirmar que, se considerássemos que os objetivos principais da
SUDELPA no Vale do Ribeira fossem o desenvolvimento econômico e social, a
experiência foi um fracasso. Mas, se considerarmos, como é a premissa deste
trabalho, que os objetivos da SUDELPA eram de caráter mais político, ou seja,
a interação territorial e marcar a presença do Estado na região, podemos
afirmar que a experiência foi exitosa, pois foi montado um sistema de transportes
e comunicações razoavelmente eficaz e a presença do Estado foi reafirmada pelo
grande número de obras de pequeno e médio porte implementadas em toda a região
(grifo nosso).

As políticas durante o período não foram direcionadas somente aos agricultores com melhor estrutura, mas, como podemos ver, as mesmas tinham um objetivo político. Este objetivo político se materializa com o golpe civil-militar ocorrido em 1964. A redução expressiva das liberdades democráticas, em muito causado pela criminalização dos movimentos sociais, trouxe um impacto ainda maior para o campo e o movimento camponês. Esta região havia baixíssima densidade demográfica na época do regime civil-militar. Neste sentido, o Vale seria um local ideal para a formação de milícias comunistas que lutavam contra o governo. O que de fato ocorreu. Em 1970, os integrantes da Vanguarda Popular Revolucionária, liderados por Carlos Lamarca, haviam instalados centros de treinamento de Guerrilha na área. Foram mobilizados quase 3000 homens das forças públicas para procurar os envolvidos. A ação envolveu diversas arbitrariedades, como ameaças aos moradores locais, casos de tortura e investidas com bombas aéreas na região (COMISSÃO CAMPONESA DA VERDADE, 2014; PETRONE, 1966).

Houve uma relação perniciosa entre as elites locais, empresários das grandes cidades e o governo da época, tanto na esfera federal como na estadual, atuando com constante 
violência e espoliação das comunidades mais pobres. Diversos são os relatos que apontam casos de violências, expulsão da terra e mortes (COMISSÃO CAMPONESA DA VERDADE, 2014). Ao exemplo do Médio Ribeira, após a abertura da rodovia SP - 165, que ligava os municípios de Eldorado e Iporanga, a SUDELPA entrou em várias comunidades que viviam do uso compartilhado da terra, criando lotes individuais. Este processo facilitou a atuação de compra e venda por parte dos grileiros, geralmente a preços irrisórios (MUNARI, 2009). Este fato foi determinante para desestabilizar estruturalmente diversas comunidades quilombolas, já que as terras vendidas, agora consideradas como uso compartilhado pela CF 1988, foram motivos de conflitos internos e relações assimétricas entre as famílias quilombolas que duram até hoje. ${ }^{38}$.

A relação entre os órgãos ambientais e as comunidades afastadas da época contribuíam para inibir a abertura de novas áreas de e extração de recursos florestais, sem lhes-dar nenhuma alternativa (MUNARI, 2009). A alternativa subentendida era do posseiro ou os então "capuavas" virassem mão-de-obra barata para os fazendeiros e grileiros da época (COMISSÃO CAMPONESA DA VERDADE, 2014). Entretanto, este momento de intenso conflito foi fundamental para a ação da Comissão Pastoral da Terra (CPT - Igreja Católica) e dos partidos e sindicatos, com grande expressão do Partido dos Trabalhadores (PT) e da Central Única dos Trabalhadores (CUT). Estas entidades influenciaram tanto a reinvindicação do direito à terra como a organização social das comunidades de posseiros e quilombolas (MUNARI, 2009).

A síntese deste tópico, é que no geral, o território do Vale do Ribeira continuaria na forte dependência da agricultura, especialmente da banana e do chá nas porções mais desenvolvidas num lado, e a realização de atividades voltadas à roça itinerante e extrativismo de subsistência pelas comunidades mais pobres, e ao extrativismo comercial do palmito e de outros produtos da floresta. Lembrando que as atividades de extração comercial do palmito iniciadas pelos grileiros e posseiros pobres alocados na região a partir da implantação da BR 116, ocorre ainda hoje, só que de maneira mais reduzida e dispersa. Na outra ponta, a concentração fundiária, os conflitos pela terra e a desigualdade que aumentaram a passos largos durante o período, só foram motivos de atenção do estado, de forma parcial e descontínua ressalta-se, no governo Franco Montoro.

\footnotetext{
${ }^{38}$ A observação do último parágrafo foi obtida a partir dos trabalhos de campo realizados no quilombo Pedro Cubas, sob a coordenação do Núcleo de Pesquisas em Estudos Interdisciplinares de Sistemas Complexos (NISC/EACH-USP).
} 
E por final, recuperando a análise de França (2005) direcionada aos posseiros pobres, principalmente os pequenos bananicultores que continuam dependentes das relações assimétricas e com um papel subordinado aos atravessadores e grandes organizações de produção e venda nas grandes metrópoles, produzindo alimentos de baixo valor agregado e com baixos retornos, causando grande desagregação familiar e perda do poder de decisão sobre o uso da terra. Se compararmos com a abordagem realizada por Valentin (2006) podemos perceber que o ciclo da banana possui não possui muitas diferenças em relação ao ciclo do arroz.

\subsection{A emergência da questão socioambiental}

As reservas de Mata Atlântica que ocupam ainda maior parte do Vale do Ribeira ainda foi alvo da crescente pressão internacional promovida pelos movimentos ambientalistas organismos internacionais na década de 1980. Aliado a este momento, o Governo do Estado de São Paulo reestruturou os arranjos institucionais e criou marcos normativos ambientais, como a Lei Federal 6.938/1981. Foi criada a Política Estadual do Meio Ambiente em conjunto com a criação do Conselho Estadual de Meio Ambiente. Estes dos instrumentos serviriam de base para a criação da Atual Secretaria do Meio Ambiente (SMA) (BRAGA, 1998; RESENDE, 2002).

A SMA foi criada em 1986 a partir da fusão de diversos órgãos do governo estadual: o Instituto Botânico (atual Instituto de Botânica), o Instituto Florestal e o Instituto Geológico, a Fundação Florestal, a Coordenadoria de Proteção aos Recursos Naturais e o Departamento Estadual de Proteção de Recursos Naturais vieram da Secretaria de Agricultura. Já a Companhia de Tecnologia e Saneamento Ambiental (CETESB) pertencia a Secretaria de Obras. Além disto, foram criadas a Coordenadoria de Educação Ambiental (CEAM) e a de Planejamento Ambiental - CPLA (RESENDE, 2002).

Houve em adição a proposta de ação conjunta entre o Estado de São Paulo e do Paraná com vistas à execução da gestão compartilhada do Complexo Lagunar Iguape-CananéiaParanaguá e criou a Plano Básico de desenvolvimento auto-sustentado para a região Lagunar de Iguape e Cananéia. Este plano tinha o objetivo de aliar a preservação com atividades turística e de exploração sustentável da região, especificamente projetos de aquicultura e pesca (BRAGA, 1998). 
As especificidades biofísicas do Vale em consonância com a emergência da questão ambiental, além da abertura do governo as propostas de preservação foram fundamentais para o surgimento de ações promovidas ONGs ambientalistas na região. O marco simbólico de consolidação das ONGs ambientalistas se deu com a implantação da Estação Ecológica Juréia Itatins. O motivo da criação da Estação vem da pressão do Movimento Pró-Jureía. Este movimento tinha como principal alvo o projeto de construção de usinas nucleares que estavam sendo planejadas no âmbito das extintas Empresas Nucleares Brasileiras (NUCLEBRAS) (TODESCO, 2007).

O Movimento Pró-Jureia tinha diversos integrantes influentes na mídia escrita, aliados a outros influentes militantes que tocavam a causa de Cubatão com a ONG OIKOS, articulam esforços para pressionar o governo em implantar uma UC em contraposição a construção de uma usina nuclear (TODESCO, 2007). No ano de 1986, numa reunião realizada na Ilha do Cardoso entre os militantes ambientalistas ${ }^{39}$ e o governador, é assinado o Decreto $\mathrm{n}^{0}$ 24.646, de 20 de janeiro de 1986. Ressalta-se que desta reunião os militantes que haviam se integrado na questão da Juréia fundam ONG SOS Mata Atlântica, atualmente uma das principais organizações ambientais no Brasil (TODESCO, 2007).

Dois anos depois surge o Instituto para o Desenvolvimento, Meio Ambiente e Cidadania - Vitae Civilis. Ambas as ONGs tinham o objetivo de realizar projetos de conservação e de mobilização para a conscientização ambiental. Esses objetivos permeavam a realização de pesquisas científicas sobre a Mata Atlântica, projetos de desenvolvimento do ecoturismo, educação ambiental, plantio do palmito juçara, pesquisas sobre etnoconhecimento e agenda 21 (TODESCO, 2007).

Se parte da literatura apresenta como o efeito positivo a implementação de UCs em áreas de relevância ecológica, a sua execução sem considerar as especificidades socioculturais condicionam invariavelmente ao conflito com as comunidades locais. Ressalta-se que os conflitos entre comunidades pobres e órgãos ambientais não surgiram na década de 1980. As comunidades residentes próximas ou em meio as UCs já sofriam com a ação repressiva da polícia florestal (FERREIRA, 2004), além dos conflitos já abordados na seção anterior (BRAGA, 1998; COMISSÃO CAMPONESA DA VERDADE, 2014; MUNARI, 2009; PEDROSO et al., 2008; RESENDE, 2002; QUEIRÓZ, 2006). Contudo, na década de 1980 os

\footnotetext{
${ }^{39}$ Segundo Todesco (2007) os militantes que participaram da formação da EEJI e da SOS Mata Atlântica são: João Paulo Capobianco, um dos fundadores do Movimento Juréia e posteriormente do Instituto Socioambiental; Adriana Mattoso, Clayton Lino Fausto Pires Maria Cecília Wey de Brito e Antônio Teleginski, militantes da causa indígena e caiçara; Fábio Feldmann, Randau Marques, Roberto Klabin, da então ONG OIKOS, e Rodrigo Mesquita, militante e jornalista do Jornal da Tarde.
} 
conflitos são intensificados, sendo os principais motivos as UCs de proteção integral e a atuação das ONGs com caráter preservacionista.

A crítica de Todesco (2007) segue principalmente no fato de que estas organizações serem criadas por pessoas de fora e com sedes localizadas fora da região. Segundo autora, o fato destas ONGs serem criadas fora da região foi um fator limitante na atuação destas com a comunidade local, devido à ausência de sensibilidade quanto à realidade das comunidades estavam inseridas nas UCs. A emergência da questão ambiental por parte dos movimentos sociais, principalmente voltados à implementação de políticas de comando e controle enfraqueceu os movimentos sociais de pequenos posseiros e agricultores que atuavam na luta pela reforma agrária. Segundo Chabaribery e colaboradores (2006, p. 22-23):

Os posseiros e pequenos agricultores da região percebem muito bem essa mudança de interesse do Estado e da sociedade e sentem-se traídos pelos ambientalistas, até então seus aliados, pois teriam deixado a luta pela realização da regularização fundiária e da reforma agrária em favor do meio ambiente.

Por outro lado, esta tensão estimularia a organização comunitária para a proteção dos seus direitos à terra e a melhor qualidade de vida, a exemplo da União dos Moradores da Juréia, criado em 1990 (TODESCO, 2007). A interação entre pessoas tecnicamente qualificadas, ou seja, os integrantes das ONGs e técnicos dos órgãos públicos ambientais, e as comunidades que eram excluídas até dos seus direitos mais básicos foi marcado inicialmente por uma relação colonizadora de tutela. No entanto, o próprio processo de interação e tensão gerou um ambiente de aprendizagem social. Os principais resultados desta interação foram:

\footnotetext{
“i) os moradores compraram a ideia da mobilização autônoma; ii) produziram suas próprias lideranças; iii) investiram na organização política de vários formatos, desde pequenas ONGs, associações civis, até organizações sindicais; iv) criaram condições de representatividade para o próprio grupo nas diversas situações de ação; v) buscaram a participação direta em pactos e projetos, quando não a elaboração de seus próprios projetos; vi) as lideranças produzidas respondem a uma lógica de ação definida por opções racionalmente orientadas no jogo político com outros atores, como ONGs e representantes governamentais e, vii) produziu-se um tipo de conhecimento híbrido e perito [...] predominante na região (FERREIRA, 2004, p. 54-55).
}

A situação de constantes conflitos serviu para parte dos movimentos ambientalistas como um ponto de reflexão sobre a sua atuação na região. Esta reflexão foi fortemente influenciada pelo contexto internacional de críticas relacionadas às áreas protegidas implantadas no modelo restritivo, principalmente nos países subdesenvolvidos, cujas florestas são ocupadas pelas diversas comunidades que dependiam do meio natural para reproduzir seus modos de vida (ADAMS et al., 2013, MUNARI, 2009; QUEIROZ, 2006; SCHERL et al., 2006). 
O movimento mais importante ocorrido no Brasil contra a destruição da floresta amazônica e pelo uso sustentável da mesma surgiu com o seringueiro e sindicalista Chico Mendes. Esta figura central do primeiro movimento socioambientalista surgido na década de 1980, organizou os seringueiros da região a partir do uso das estruturas dos Sindicatos dos Trabalhadores Rurais, no movimento pacífico denominado empate, como uma estratégia para impedir o avanço da franja pecuarista na floresta amazônica. O movimento ganhou amplitude internacional, principalmente pela defesa do uso sustentável das florestas. Porém, o fato de Chico Mendes ter se tornado uma figura conhecida mundialmente não impediu o seu assassinato em 1988. Assim, este triste fato fez com que a imagem do seringueiro se tornasse um mártir na defesa da luta pela floresta, além de fazer emergir a categoria da "Reserva Extrativista", como uma proposta de UC que promove o uso racional e planejado das florestas $^{40}$ (FERNANDES; WELCH; GONÇALVES, 2012; NAKASHIMA, 1992).

Este debate também se deu no Fórum Brasileiro de ONGs e Movimentos Sociais para o Meio Ambiente e Desenvolvimento (FBOMS) e consequentemente na Conferência das Nações Unidas sobre o Meio Ambiente e o Desenvolvimento (UNCED), realizada no Rio de Janeiro em 1992, ou simplesmente Rio-92.

Foi a partir desta ampla reflexão que surgiu o Instituto Socioambiental (ISA). Fundada em 1994, esta ONG surge com o objetivo de propor soluções de forma integradas a questões sociais e ambienteis "com foco central na defesa de bens e direitos sociais, coletivos e difusos

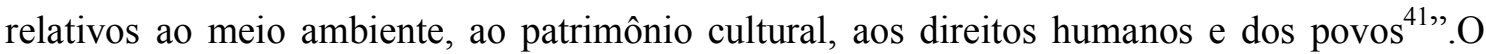
ISA tem atuação no Vale do Ribeira, mas suas ações são estruturadas na Amazônia. No Vale do Ribeira, o ISA tem atuado junto as comunidades quilombolas, em especial na porção do alto e médio ribeira. A ONG atua na articulação de projetos voltados a organização comunitária e planejamento dos territórios quilombolas, preservação e uso sustentável do Bioma Mata Atlântica e incentivo à produção agroecológica ${ }^{42}$.

A ONG também possui forte atuação junto ao Movimento dos Ameaçados por Barragens (MOAB) e a Equipe de Articulação e Assessoria às Comunidades Negras do Vale

\footnotetext{
${ }^{40}$ Outra peculiaridade é revelada quando comparamos a o Vale do Ribeira com experiências que ocorriam no país e no mundo. Enquanto na Amazônia havia um forte movimento em prol do uso racional da floresta, no Vale do Ribeira por outro lado o debate sobre a manutenção da biodiversidade tinha uma forte orientação preservacionista.

${ }^{41}$ Instituto Socioambiental - O ISA. Disponível em: <http://www.socioambiental.org/pt-br/o-isa $>$. Acesso em 15 jan. 2015.

${ }^{42}$ Há o reconhecimento de diversos autores em relação as atuações da ONG na região (MUNARI, 2009; PEDROSO Jr et al, 2008; FUTEMMA et al, 2014, no prelo). E somente com as publicações desta organização é que temos uma visão geral das comunidades quilombolas a partir de diversas publicações, sendo as mais relevantes: Santos e Tatto (2008) e Andrade e Tatto (2013).
} 
do Ribeira (EAACONE). Esses movimentos lutam contra o projeto de meados de 1980, ligado à Companhia Brasileira de Alumínio, braço do Grupo Votorantin. Esta empresa pretende instalar as Barragens do Tijuco Alto no Rio Ribeira de Iguape, para a geração de energia que será direcionada a produção de alumínio (GALVANESE, 2009).

Porém, esta mudança de visão das ONGs não foi acompanhada pelos órgãos submetidos à Secretaria do Meio Ambiente (SMA). Os conflitos entre os técnicos e as comunidades tradicionais e de agricultores familiares continuam até o momento. A implantação de UCs de proteção integral, baseada na atuação de comando e controle, sem nenhuma articulação com as comunidades locais, são estratégias pouco efetivas. As comunidades mais pobres e menos integradas ao mercado não tem outra alternativa a não ser viver dos recursos ali disponíveis, tanto para sobrevivência como para obter alguma renda (RAIMBERT, 2010). Por outro lado, o formato ineficiente de gestão não evita a degradação causada por terceiros e pelos grandes fazendeiros, que cada vez mais expandem suas áreas até os limites das áreas mais acidentadas e próximas às UCs (RESENDE, 2002). Além disso, geralmente as comunidades pobres são subcontratadas nos limites destas áreas por terceiros para extração ilegal de palmito (FAKIH, 2013, p. 44). Uma gestão que de fato fosse integrada com as comunidades próximas a UCs, não somente seria benéfico às comunidades, como também facilitaria de sobremaneira a atuação dos técnicos ambientais na região. Sem falar que reduziria os custos estatais, ou seja, teríamos um jogo onde ambas às partes estariam ganhando, além de facilitar o processo de gestão das UCs

Se por um lado observamos a intensificação das relações conflituosas entre os diversos agentes em questão, por outro temos um estado tanto na esfera federal como na esfera estadual, que virou às costas para o Vale na década de 1990, principalmente quando se observa a questão dos agricultores familiares. A ação do governo estadual nesta década se resumiu ao financiamento de projetos ambientais e de desenvolvimento local que pouco surtiu efeito. As ações no território se deram em sua maior parte por parte das ONGs.

Em 1989 surge o Consórcio de Desenvolvimento Intermunicipal do Vale do Ribeira (CODIVAR). Este consórcio surgiu com a união de 20 municípios em torno da otimização de ações de desenvolvimento socioeconômico na região (CRUZ et al., 2005). Junto ao CODIVAR, foi criado o Fundo de Desenvolvimento Econômico e Social do Vale do Ribeira (FVR). A única ação efetiva que encontramos na literatura em relação a este consórcio e do respectivo fundo está relacionado a criação das indústrias têxteis de Registro (FRANÇA, 2005). Em 1995, o Instituto da Cidadania, organizou a elaboração do Plano de Desenvolvimento Sustentável do Vale do Ribeira. Este plano foi surgiu das Caravanas da 
Cidadania, organizado pelo então Ex-presidente Lula. Segundo o relatório do IDESC (2005), o plano:

\begin{abstract}
“envolveu sociedade civil e governos locais (municípios e estado). Tinha um caráter de apontar as linhas do desenvolvimento regional sustentável: regularização fundiária, duplicação da BR 116, criação de uma universidade pública e gratuita, apoio a agricultura familiar, apoio as comunidades tradicionais como quilombolas [...] e caiçaras, apoio a projetos de geração de emprego renda e ações emergenciais de combate à fome" IDESC (2005, p. 32, grifo nosso).
\end{abstract}

As corajosas proposições deste projeto também não se traduziram em ações. Vinte anos depois a única universidade pública na região é a UNESP de Registro. Dentre os projetos realizados pelo governo, temos a elaboração de um Plano de Emergência executado após as cheias de 1997. Entretanto as ações foram voltadas somente para obras de infraestrutura. Foram prometidas ações mais estruturantes, como ações integradas e com efeitos estruturais, porém, tais medidas não foram priorizadas.

Por fim, entre 2001 e 2002 há uma primeira integração de ações entre o governo federal e estadual na execução do Programa Comunidade Ativa (PCA), promovida no Governo Mário Covas (1995-2001). Esta foi a primeira ação coordenada em ambas as esferas com o objetivo de induzir a estratégia de Desenvolvimento Local Integrado e Sustentável (DLIS). O processo de execução da estratégia foi amplamente participativo, o que resultou em 2001 no Programa de Fortalecimento das Vocações das Comunidades do Vale do Ribeira Agenda Rural. A inovação do plano se dava pelo esforço em integrar o MDA e o CNDRS na esfera federal, o CODIVAR e o Conselho de Bacias Hidrográficas $(\mathrm{CBH})$ e no âmbito local o Sindicato Regional da Agricultura Familiar do Vale do Ribeira e Litoral Sul (SINTRAVALE).

O plano foi elaborado, porém como as esferas de governo não se comprometeram com o repasse de recursos, o plano não foi executado, novamente (IDESC, 2005a). Contudo, a organização das comunidades em especial as de agricultores familiares foi fundamental, pois é neste processo que surgem as principais associações, cooperativas e sindicatos da região, além de fortalecer as organizações já existentes. Alguns exemplos, o próprio Sintravale citado acima, o Instituto de Desenvolvimento Sustentável e Cidadania do Vale do Ribeira (IDESC), a Associação de Economia Solidária e Desenvolvimento Sustentável (AGUA), entre outras organizações.

Em síntese, com este breve contexto histórico nos possibilitou observar que o Vale do Ribeira no referido período foi palco de diversas ações, projetos e alvo de outros tantos diagnósticos e elaboração de planos. Porém a intermitência e pulverização das ações e planos propostos não lograram seus objetivos. Percebemos também que a implementação de políticas 
ambientais, em especial as UCs acirraram os conflitos entre as comunidades ONGs e órgãos ambientais do Estado. Entretanto este também foi um processo de grande aprendizado, o que levou os cidadãos a se organizarem em torno das reivindicações de melhor qualidade de vida e da resistência pelo seu lugar de moradia.

\subsection{O PRONAT no Vale do Ribeira: formação do arranjo territorial}

A implementação da PRONAT no Vale foi marcada pela integração das configurações territoriais de outros arranjos institucionais. O primeiro território foi implementado em 2004, o Consórcio de Segurança Alimentar e Desenvolvimento Social - CONSAD, do MDS ${ }^{43}$. Diferente da proposta do TR, mas de acordo com a perspectiva da abordagem territorial, o CONSAD trazia consigo a missão em caráter normativo de articular a execução do Programa Fome Zero nas localidades mais vulneráveis, tendo como objetivo a redução da extrema pobreza e a melhoria de oportunidades de geração de renda.

O surgimento e difusão dos CONSAD no Brasil antecedeu a criação da Lei que regulamentou os consórcios públicos (11.107/2005). Por tal fato, os primeiros CONSADs possuem na verdade o formato de associações civis sem fins lucrativos, ou um Consórcio com personalidade de direito privado, estruturas estas regidas pelo Código Civil. Por isso, apesar de constar o nome "consórcio" o arranjo é na verdade uma associação.

A estrutura normativa deste arranjo tinha por finalidade executar as atividades previstas no Acordo de Programa de Segurança Alimentar e Desenvolvimento Local com vistas aos seguintes objetivos: i) promover o desenvolvimento econômico e social sustentável e o combate à pobreza. ii) planejar e executar atividades destinadas a instituir e ampliar as ações de segurança alimentar e nutricional e de promoção ao desenvolvimento local; iii) estimular a cooperação intermunicipal e a elaboração de estudos e pesquisas que contribuam para a promoção do desenvolvimento local; iv) preservar, defender e conservar o meioambiente e promover o desenvolvimento sustentável. Estes objetivos em conjunto formavam a base operacional do Programa Fome Zero (PFZ), sob coordenação da Secretaria de Segurança Alimentar e Nutricional - SESAN-MDS (IBAM, 2004).

A estrutura do CONSAD Vale do Ribeira foi articulada com o PRONAT, que estava em processo de implementação, atuando na execução de projetos pactuados em torno do fortalecimento da agricultura familiar. Visando uma maior atenção aos valores ambientais da

\footnotetext{
${ }^{43}$ Ao todo, o MDS implantou 40 CONSADs em todo o país (ORTEGA, 2014).
} 
região, houve uma inédita articulação da composição descrita acima com a proposta de elaboração da Agenda 21 regional, coordenado pela Secretaria Nacional de Políticas para o Desenvolvimento, do Ministério do Meio Ambiente (MINISTÉRIO DO MEIO AMBIENTE, 2004).

A estrutura do colegiado é composta por 150 representantes municipais e suplentes eleitos em assembleia, onde cada município indicaria até seis representantes. A composição seria de 2/3 voltada para as organizações da sociedade civil, e o terço restante para o poder público. Para se candidatar, o indivíduo deveria estar obrigatoriamente vinculado a alguma associação ou cooperativa, sendo vedada a candidatura de indivíduos sem vínculos associativos (FAVARETO; SCHORDER, 2007).

Quanto ao seu quadro organizacional, o modelo de estrutura de organização será composto da seguinte forma.

- Fórum - nível máximo de deliberação, envolvendo assuntos a serem deliberados como políticas públicas prioridades e definição de Planos de Ação.

- Conselho Fiscal - área específica incumbida de acompanhar as contas do CONSAD, tanto relacionadas as finanças como os procedimentos contábeis.

- Comissão Executiva - são as arenas colocadas a nível gerencial que tem a incumbência de animar e articular as propostas específicas. As arenas constituídas neste nível podem tomar corpo de câmara temática, comitê, grupo de trabalho, etc;

- Secretaria executiva: situada no nível de execução operacional, a secretaria tem a função de suporte administrativo para o funcionamento do CONSAD;

- Programas - Correspondem às ações específicas articuladas no Plano de Ação do CONSAD, executadas sob acompanhamento da Secretaria Executiva

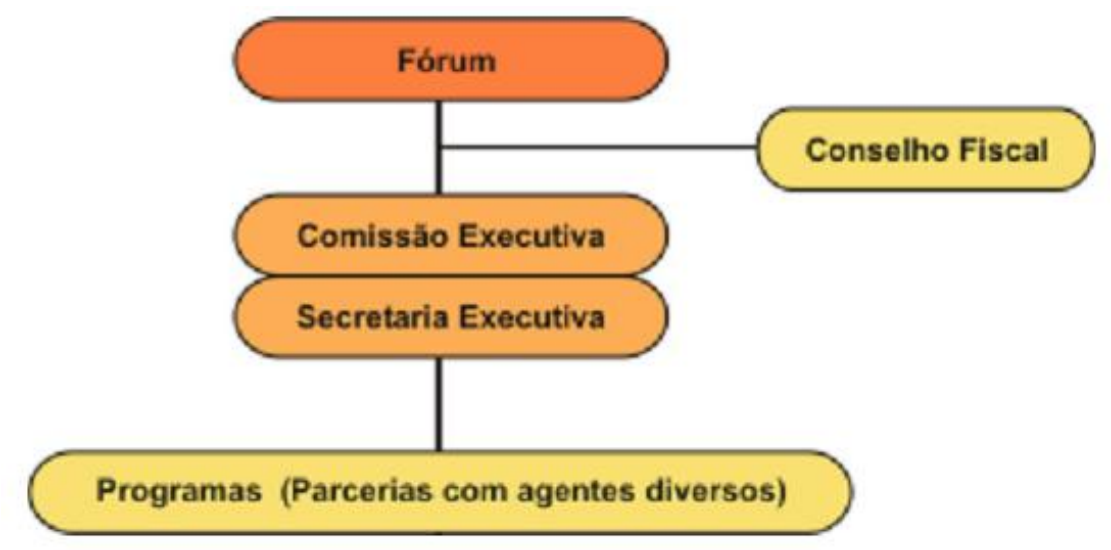

Figura 5.8 - Estrutura organzacional do CONSAD. Fonte: IBAM (2004). 
Vale a pena ressaltar que a implementação de um arranjo CONSAD não ocorre no "vácuo". Nessa mesma época Vale do Ribeira estava no contexto de efervescência participativa. A região se encontrava em meio á inúmeras experiências voltadas à formação de associações, lutas por direitos quilombolas, pelos créditos diferenciados aos agricultores, além da elaboração de diversos projetos voltados a geração de renda e conservação ambiental.

A implementação dos arranjos territoriais integrados entre o MDA, MDS e MMA promoveu um ambiente de aposta por parte da sociedade civil organizada no CONSAD como uma arena institucional de debate das demandas e canalização dos recursos repassados pelo governo federal. Pretende-se aqui destacar a organização responsável pela mobilização e gestão do CONSAD nos primeiros anos de sua existência. Este trabalho pretende dar uma maior atenção ao processo de mobilização da sociedade civil em torno da construção de planos e projetos voltados ao desenvolvimento da região e a sua relação com a implementação das políticas de caráter territorial no Vale do Ribeira.

\subsubsection{Construindo o Projeto Vale do Ribeira Sustentável}

A construção do Projeto Vale do Ribeira Sustentável (VRS) foi iniciada em 2004, contudo, é necessário uma regressão para contextualizar brevemente a base de experiências sociais sob o qual este projeto estava inserido. Neste sentido, o Projeto Vale do Ribeira Sustentável nasce a partir do esforço e coordenação do Instituto de Desenvolvimento Sustentável e Cidadania do Vale do Ribeira - IDESC.

O IDESC é uma ONG fundada em 2001, sendo seu objetivo inicial desenvolver estudos, pesquisas e projetos visando promover o desenvolvimento sustentável e a melhoria da qualidade de vida da população do Vale do Ribeira. Entre os anos de 2001 e 2003, o IDESC realizou trabalhos junto aos agricultores familiares em relação às implicações da legislação ambiental no desenvolvimento da agricultura familiar. Ademais, a ONG desenvolveu oficinas direcionadas a melhorar a organização dos agricultores familiares em torno das políticas públicas de crédito e de infraestruturas financiadas pelo MDA. Já entre Nos anos de 2003 e 2004 o IDESC participou ativamente dos encontros e seminário promovidos pelo governo federal da época. Essas reuniões voltavam-se construção de estratégias para a implementação do CONSAD no Vale do Ribeira, além promover a mobilização das organizações da região em torno das politicas públicas de abordagem territorial. 
Em 2004 o MMA publicou o Edital 03/2004 que propõe o apoio financeiro a elaboração da agenda 21, então denominada "Plano de Desenvolvimento Territorial Sustentável Vale do Ribeira”. Para efetivar a elaboração deste projeto, o edital tinha como um dos critérios que o proponente do projeto deveria ser um membro do CONSAD. No mês de novembro de 2004 o Fórum CONSAD decide que o IDESC deve ser o proponente do projeto. Nos dias 3 e 4 de dezembro ocorreu a II Oficina de Desenvolvimento Territorial onde o IDESC apresentou a versão final do projeto. Com a aprovação do mesmo, no dia 24 de dezembro foi assinado um convênio entre o IDESC e o MMA, dando inicio ao projeto intitulado "Elaboração do plano de desenvolvimento territorial sustentável do Vale do Ribeira e implantação de projetos socioambientais prioritários" (IDESC, 2004).

O Projeto VRS foi aprovado em 2005 com o prazo de 24 meses para a sua execução. O valor financiado pelo MMA foi de R\$750.000,00. Para a execução do Projeto VRS, o IDESC tinha uma equipe de cinco coordenadores gerais, cinco técnicos e doze mobilizadores subregionais. Quanto ao alcance das ações do Projeto VRS, surge um novo recorte territorial: o plano foi elaborado incluindo no total trinta e dois municípios ${ }^{44}$, sendo os 25 municípios de São Paulo e sete municípios do Estado do Paraná, a saber: Adrianópolis, Doutor Ulysses, Tunas do Paraná, Bocaíva do Sul, Rio Branco do Sul, Itaperuçu e Cerro Azul. A inclusão dos municípios do Paraná tinha como pano de fundo o esforço por um olhar mais integrado sobre a Bacia Ribeira de Iguape como um todo.

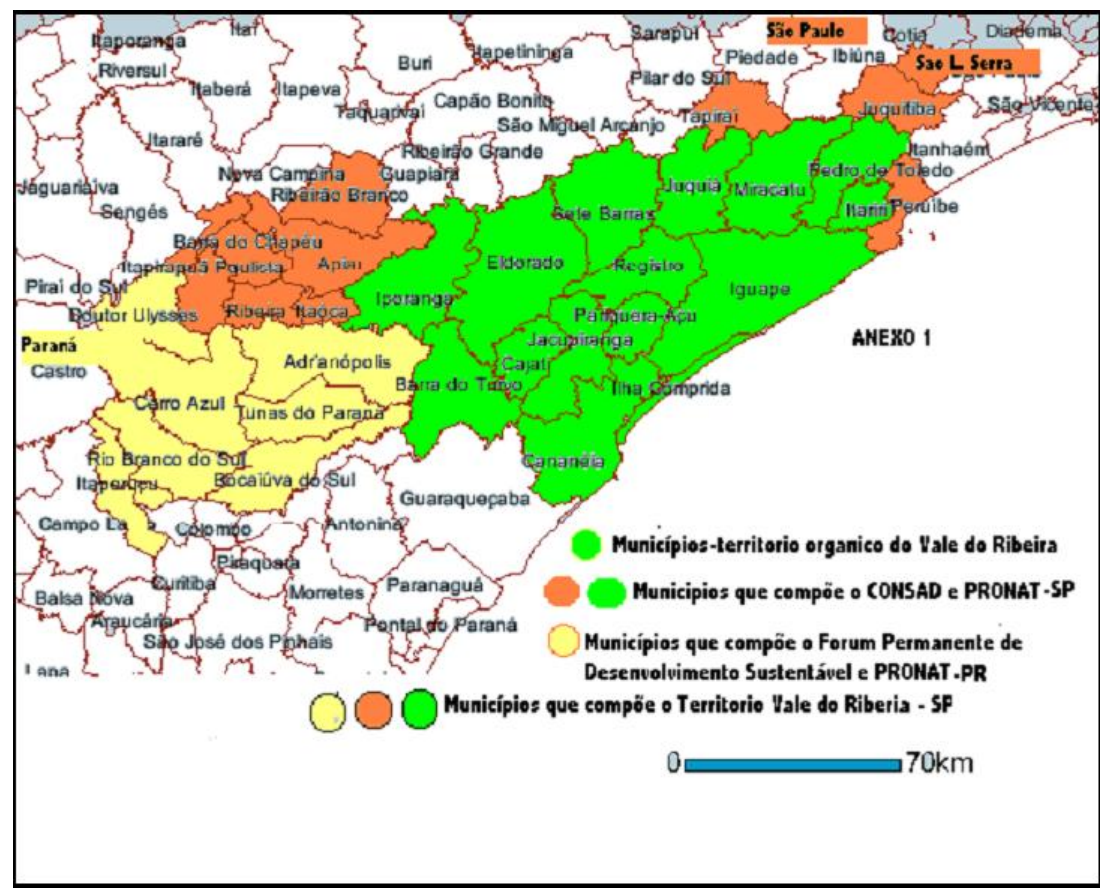

Figura 5.9 - Mapa do Território do Vale do Ribeira São Paulo e Paraná. Fonte: IDESC (2004).

\footnotetext{
${ }^{44}$ Para fins de recorte metodológico, este trabalho não abordou a porção paranaense do Vale do Ribeira.
} 
A justificativa do Projeto VRS era da elaboração de um plano a nível territorial que fosse reconhecido pelas comunidades locais e pelo poder público local, além da criação de alternativas de desenvolvimento inclusivo e sustentável. Esta justificativa está ligada a crítica dos diversos planos regionais elaborados principalmente nos últimos 30 anos, que, apesar do grande esforço na elaboração, não criava efeitos positivos para as comunidades. Além disso, os planos anteriores foram marcados pela sua intermitência e descontinuidade. Assim, a elaboração do plano previa um amplo processo participativo, que envolveria os diversos segmentos da sociedade civil organizada e os diferentes níveis de governo. As metas elaboradas estão elencadas abaixo:

- Meta I - Mobilizar 32 municípios para a participação, elaboração e aprovação do Plano de Desenvolvimento Sustentável do Vale do Ribeira;

- Meta II - Realizar oficinas de formação e capacitação da equipe técnica do projeto, das instituições parceiras, Grupos de Mobilização Local do CONSAD e atores sociais da sociedade civil e governança com atuação no território;

- Meta III - Promover o uso dos diferentes meios de comunicação, facilitar o aceso a informação e divulgar as atividades do projeto para garantir a mobilização a e participação dos diferentes atores sociais no projeto em todo o território;

- Meta IV - Fortalecer e ampliar a capacidade de articulação da ação institucional através da estruturação do CONSAD-VR e fortalecer o Fórum Permanente de Desenvolvimento Sustentável dos Municípios do Vale do Ribeira, Paraná;

- Meta V - Definir mecanismos e critérios para a elaboração, sistematização, priorização, financiamento e implantação de sub projetos novos ou em andamento na área de abrangência do território do Vale do Ribeira;

- Meta VI - Monitorar, acompanhar, registrar e avaliar as metas e atividades.

Para operacionalizar essas metas, o território proposto foi dividido em 5 microrregiões e 12 sub-regiões a saber:

\section{Microrregião I}

- Sub-região 1: Itaperuçu, Bocaiúva, Rio Branco do Sul

- Sub-região 2: Adrianópolis, Tunas do Paraná, Cerro Azul, Dr. Ulisses

\section{Microrregião II}

- Sub-região 3: Iguape, Ilha Comprida

- Sub-região 4:. Cananéia, Pariquera-Açu 


\section{Microrregião III}

- Sub-região 5: Itapirapuã, Itaóca, Ribeira

- Sub-região 6: Apiaí, Ribeirão Branco, Barra do Chapéu

\section{Microrregião IV}

- Sub-região 7: Iporanga, Eldorado

- $\quad$ Sub-região 8: Registro, Sete Barras

- Sub-região 9: Jacupiranga, Cajati, Barra do Turvo

\section{Microrregião V}

- Sub-região 10: Pedro de Toledo, Itariri, Peruíbe

- Sub-região 11: São Lourenço, Juquitiba

- Sub-região 12: Juquiá, Miracatu, Tapiraí

A estrutura inovadora de inclusão dos municípios dos Estados de São Paulo e Paraná legitimaria o recorte da Bacia Hidrográfica do Rio Ribeira de Iguape. Foram criados mecanismos de transmissão para aumentar a permeabilidade e o diálogo entre organizações da sociedade civil e poder local a estrutura de planejamento territorial. Além disso, a estrutura

previa cadeiras reservadas as eleições de representantes de quilombolas, indígenas e assentados.

A partir desta esquematização, a equipe montada com 12 mobilizadores de projetos tinha como meta principal a mobilização da sociedade civil organizada em torno da realização de um diagnóstico local tanto pelo método de oficinas como pela pesquisa de documentos e projetos parcialmente executados nas sub-regiões. Este trabalho tinha o intuito de primeiro avaliar de forma crítica os projetos executados e segundo aproveitar as experiências realizadas para fortalecê-las. O processo de mobilização popular contou com ampla divulgação pela mídia local por via de rádios, criação de jornais, jornal mural, cartazes, cartilhas, dentre outros. Este esforço foi uma meta prevista para difundir a maior parte da população as ações que estavam ocorrendo referentes à criação do Projeto VRS.

Em 2005 ocorreu a mobilização e articulação dos atores locais nas seguintes etapas: o diagnóstico do território, a realização de oficinas de nivelamento conceitual e de planejamento das ações dos mobilizadores, mobilização e ampliação das parcerias institucionais, sistematização dos entraves ao desenvolvimento sustentável no Vale do Ribeira, sistematização das propostas para superar os entraves e propostas de elaboração do Projeto VRS. Além disso, foram realizadas diversas reuniões que sistematizavam as dúvidas em 
relação à elaboração dos projetos e do plano territorial, bem como em relação a estrutura do CONSAD.

No final de 2005, o levantamento de informações locais apontou para a existência de mais de 300 demandas de projetos. Este levantamento estava condicionado ao início da execução da meta de capacitação em elaboração de projetos. As oficinas foram realizadas em todas as microrregiões com o objetivo de iluminar projetos engavetados, melhorar propostas preliminares enviadas pelo poder público e por organizações, além de discutir teoricamente como elaborar projetos e concorrer a editais.

Dentre os encontros, oficinas, seminários e reuniões, o processo de mobilização, sensibilização e capacitação realizada no âmbito do CONSAD e operacionalizado pelo IDESC chegou ao número de 125 encontros realizados. Esse esforço realizado praticamente dobrou as parcerias institucionais, saindo de 28 para 53 instituições no final do ano de 2005. As atividades realizadas abrangeram um total de 130 entidades entre a porção paranaense e paulista do Vale do Ribeira (IDESC, 2005a).

O processo de legitimidade foi garantido inclusive com as eleições realizadas para a composição das cadeiras no biênio 2005/2006. A eleição do presidente ocorreu em março, com a subida do prefeito de Cananéia, Geraldo Carlos Carneiro (DEM). O Vice foi o então presidente do SINTRAVALE, Henrique da Mota Barbosa (IDESC, 2005b). As eleições dos representantes microrregionais ocorreu entre todos os municípios, a exceção de Barra do Turvo, Itapirapuã Paulista, Ribeira. Foram eleitos membros para a comissão executiva (dez titulares e dez suplentes) e representantes para o Conselho Fiscal (oito titulares e oito suplentes).

Em 2006 a continuidade do projeto se deu com a mobilização da sociedade civil organizada e do poder público local a partir dos mobilizadores das sub-regiões e da divulgação das reuniões, oficinas e conferências nos jornais locais. As etapas de sensibilização e mobilização junto a sociedade civil organizada realizadas no primeiro ano de execução do projeto levado a cabo pelo IDESC permitiram consolidar o processo de construção do Plano VRS. As prefeituras foram mobilizadas a partir de discussões realizadas no âmbito dos fóruns de pacto do território, envolvendo os 25 municípios ligados ao CONSAD e os sete municípios ligados ao Fórum Paraná.

As atividades de mobilização realizadas nas 12 sub-regiões resultaram na obtenção de documentos referentes a dados municipais e projetos realizados, além de informações sobre os desafios enfrentados pelas comunidades. Este material serviu de base para a construção do diagnóstico territorial, bem como serviu de subsídio para a elaboração das primeiras versões 
do Projeto VRS. Desta forma, o CONSAD em articulação com as entidades parceiras organizou um ciclo de conferências microrregionais e uma conferência regional. Essas conferências objetivavam discutir quais seriam as principais diretrizes, prioridades e conceitos norteadores plano territorial. O objetivo cental era de garantir a ampliação da participação e do princípio da co-responsabilidade por parte dos órgãos públicos locais na promoção do desenvolvimento e da sustentabilidade no Vale do Ribeira.

Desta forma, no mesmo ano ocorreram quatro Conferências Microrregionais nos municípios de Tunas do Paraná, Miracatu, Registro e Apiaí, nesta ordem. Os participantes das conferências elaboraram e aprovaram os regimentos internos, e debateram as propostas que deveriam ser incluídas no texto base do plano territorial. Ao final das reuniões ocorriam as eleições para os delegados que fariam parte da I Conferência Territorial. As conferências microrregiões possibilitaram uma ampla participação de diversas entidades da sociedade civil e do poder público. Participaram também organizações que não estavam vinculadas ao CONSAD, como a tabela abaixo mostra.

Tabela 5.10 - Quadro geral do Número de Delegados eleitos para participar da Conferência Territorial, de acordo com a qualificação do delegado e o segmento de representação.

\begin{tabular}{|c|c|c|c|c|c|c|c|c|}
\hline \multirow[b]{2}{*}{ Número } & \multirow[b]{2}{*}{ Delegados } & \multirow[b]{2}{*}{ Presentes } & \multicolumn{3}{|c|}{ PODER PÚBLICO } & \multicolumn{3}{|c|}{ SOCIEDADE CIVIL } \\
\hline & & & CONSAD/FORUM & Eleitos & Total & $\begin{array}{c}\text { Total } \\
\text { CONSAD/ } \\
\text { FORUM }\end{array}$ & Eleitos & Total \\
\hline Tunas do Par & 53 & 106 & 8 & 12 & 20 & 11 & 22 & 33 \\
\hline Apiaí & 33 & 66 & 2 & 9 & 11 & 2 & 20 & 22 \\
\hline Total & 209 & 593 & 18 & 42 & 60 & 53 & 96 & 141 \\
\hline Indígenas & 12 & & & & & & & \\
\hline Quilombolas & 16 & & & & & & & \\
\hline Assentados & 2 & & & & & & & \\
\hline
\end{tabular}

Fonte: IDESC, 2006a, p. 8. Adaptado por: Joaquim Júnior

É observado que as conferências microrregionais mobilizaram quase 600 pessoas de todo o território do Vale do Ribeira. Por sua vez, estes encontros formou o subsídio para a realização da I Conferência Regional de Desenvolvimento Sustentável do Vale do Ribeira que ocorreu nos dias 15 e 16 de agosto de 2006 no município de Registro, reunindo 311 pessoas entre delegados eleitos e convidados. O encontro reuniu ampla gama de segmentos da sociedade civil como comunidades quilombolas, indígenas, caiçaras, ribeirinhos, assentados, jovens, mulheres, representantes de sindicatos e associações, além de representantes de prefeituras, câmaras, secretarias de estados e do governo federal. 
Os debates permearam inúmeros temas, a saber: políticas públicas; educação; cultura; saúde; assistência e lazer; segurança pública; agricultura familiar; pesca e aquicultura; turismo; mineração; conselhos municipais e regionais; comunidades tradicionais; orçamento público; desenvolvimento socioeconômico e meio ambiente; inclusão social; segurança alimentar; geração de emprego e renda; regularização fundiária e reforma agrária; macrozoneamento socioambiental; infraestrutura e serviços; saneamento ambiental; rodovias e estradas; comunicação e informação.

Após o amadurecimento do debate e o consenso das propostas, as mesmas foram encaminhadas para sistematização e elaboração do documento final. Este documento seria pactuado entre as prefeituras e outros fóruns existentes no território como o Comitê de Bacia Hidrográfica do Rio Ribeira e Litoral Sul e o Consórcio de Desenvolvimento Integrado do Vale do Ribeira - CODIVAR.

Mas a principal decisão tomada na Conferência foi a ratificação do documento intitulado "Projeto Vale do Ribeira Sustentável: Plano de Desenvolvimento Territorial Sustentável do Vale do Ribeira". Este documento está separado em três partes compostas pelo diagnóstico do território, pelas definições conceituais e diretrizes e as propostas divididas em seis dimensões. É interessante destacar o conceito de desenvolvimento sustentável formulado no projeto a partir de considerações da realidade local do Vale:

“O desenvolvimento territorial sustentável do Vale do Ribeira deve promover integralmente a melhoria da qualidade de vida para toda a população local, aumentar a autoestima e às expectativas da geração atual e garantir os direitos das gerações futuras. Deve atender ao princípio da democracia no acesso à terra e efetuar a regularização fundiária. Deve atender de forma universal e com qualidade às necessidades básicas de segurança alimentar, educação, saúde, moradia, transporte e segurança pública. Deve promover a geração de trabalho e renda a criação de mais e melhores empregos, com investimentos equitativos em infraestrutura e em políticas de inclusão social e de combate à pobreza. Deve respeitar o meio ambiente e todas as formas de vida, garantindo a conservação e o uso dos recursos naturais de uma forma equilibrada e consciente. Deve basear-se em processos democráticos e participativos, no reconhecimento do processo histórico e das características geográficas de formação do território e no respeito mútuo à nossa diversidade étnica, social, cultural, religiosa, econômica, política e de gênero” (IDESC, 2006a).

Além da construção do Plano Vale do Ribeira Sustentável, o CONSAD estabeleceu o cumprimento das metas de capacitação e projetos com a execução do II módulo de capacitação 
em elaboração de projetos, em continuidade as oficinas realizadas em 2005. As oficinas do II Módulo foram organizadas em janeiro de 2006 e abrangeu todas as microrregiões. Ao término das oficinas, o trabalho dos técnicos a frente do Projeto Vale do Ribeira Sustentável concentraram-se no acompanhamento da elaboração dos projetos, em especial aos que se enquadravam nos editais abertos do CONSAD/MDS e do MDA (assistência técnica e PROINF).

Ao final da etapa de acompanhamento dos projetos, o núcleo diretivo do CONSAD e a equipe técnica do Projeto VRS iniciaram a tarefa de elaborar um edital para a seleção dos projetos socioambientais prioritários, como uma das metas previstas no projeto. O processo de elaboração do edital foi fundamentado nas propostas surgidas dos módulos de oficinas de projetos realizados anteriormente. A elaboração do edital contou com contínua participação popular na discussão dos pontos polêmicos e definição dos critérios para seleção. O limite máximo de financiamento por projeto seria de $\mathrm{R} \$ 10.000,00$ e contemplaria 22 instituições (num total de $\mathrm{R} \$ 220.000,00$ previstos) distribuídas ao longo dos 32 municípios. Os critérios de escolha dos projetos foram: i) a participação da comunidade beneficiada no processo de elaboração e implementação do projeto; ii) a participação da entidade proponente nas atividades do CONSAD, do Fórum Paraná e do Projeto VRS/Agenda 21 e, iii) a importância da integração do poder público, da entidade proponente e do público atendido.

Após intenso debate, em abril de 2006 o edital foi referendado no CONSAD sob o título "Edital Vale do Ribeira Sustentável/Agenda 21 - $\mathrm{N}^{0}$ 01/2006". As linhas temáticas definidas para os projetos socioambientais foram: uso sustentável dos recursos naturais (manejo agroflorestal, artesanato, ecoturismo); fortalecimento das organizações de base (capacitação em gestão participativa); conservação de recursos naturais (recuperação de áreas degradadas em pequena proporção, da mata ciliar, viveiros, etc.) e, implantação da Agenda 21 local, e reaproveitamento dos resíduos sólidos (coleta seletiva) (IDESC, 2007, p. 15).

Realizaram-se reuniões de divulgação e orientação dos potenciais projetos a serem financiados. Ao final do mês de junho, vinte e três propostas foram encaminhadas para avaliação. No mês de julho as propostas aprovadas foram divulgadas, dezesseis ao todo. Após a divulgação dos resultados da seleção, foi encaminhado um oficio especial das entidades proponentes comunicando a aprovação e encaminhamentos para a execução do projeto. Os projetos aprovados foram referendados na I Conferência Regional do Território do Vale do Ribeira realizada em agosto. Antes de executar os projetos, as entidades proponentes participaram do Encontro de Capacitação para Entidades. Este encontro tinha o objetivo de esclarecer todos os passos da execução de projetos. 
A execução dos projetos foi acompanhado pelas equipes do Projeto VRS de forma contínua, inclusive no controle direto das finanças e da prestação de contas. A não utilização dos recursos destinados ao financiamento dos projetos em sua totalidade gerou a oportunidade do lançamento de um novo edital no ano de 2007, que será melhor especificado nas próximas páginas.

Em 2007 houve um processo de renovação do CONSAD a partir da renovação do seu estatuto com a criação das microrregiões, as vice-presidências e as câmaras temáticas.

Destaca-se neste momento a alteração das divisões microrregionais e a própria configuração territorial pela qual o CONSAD atuava. Ao final da reformulação, o território do CONSAD Vale do Ribeira ficou com o mesmo número de municípios do atual momento, separado da seguinte forma:

- Microrregião I - Alto Vale (Barra do Chapéu, Apiaí, Itaóca, Ribeirão Branco, Itapirapuã Paulista, Ribeira e Iporanga).

- Microrregião II - Eixo-BR (Registro, Sete Barras, Eldorado, Cajati, Jacupiranga e Barra do Turvo);

- Microrregião III - Lagamar (Ilha Comprida, Iguape, Cananéia, Peruíbe, Pariquera-Açu e Itariri) e,

- Microrregião IV - Portal do Vale (Juquiá, Tapiraí, Miracatu, São Lourenço da Serra, Juquitiba e Pedro de Toledo). Essa alteração desfaz a confusão entre a proposta territorial do Projeto Vale do Ribeira Sustentável e o CONSAD Vale do Ribeira.

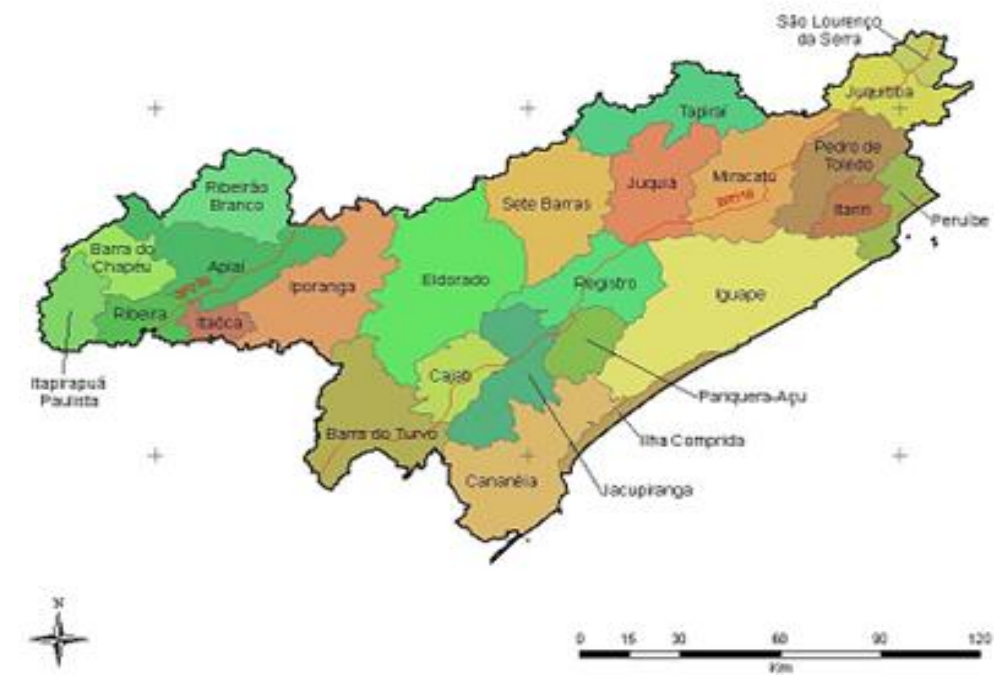

Figura 5.10 - Mapa da alteração da divisão regional no âmbito do CONSAD em 2007. Fonte: MDA (2010). Adaptado pelo autor. 
Já em relação ao trabalho de gestão e articulação promovido no CONSAD, no referido ano houve a aproximação com o Ministério da Integração Nacional, que reconheceu tanto o CONSAD como o Fórum Paraná como arenas privilegiadas de interlocução entre as demandas territoriais e a oferta do poder público para a articulação e definição de projetos. Neste sentido, o MIN integrou o território do Vale do Ribeira de ambos estados com o Plano de Ação da Mesorregião Diferenciada Vales do Ribeira de Guaraqueçaba (PROMESO). O arranjo territorial do PROMESO era composto por 39 municípios, sendo 23 do Estado de São Paulo, e outros 16 do leste do Estado do Paraná. A verdade é que o PROMESO havia incluído todos os municípios do litoral norte paranaense, à saber: Campina Grande do Sul, Morretes, Guaratuba, Matinhos, Pontal do Paraná, Antonina e Guaraqueçaba.

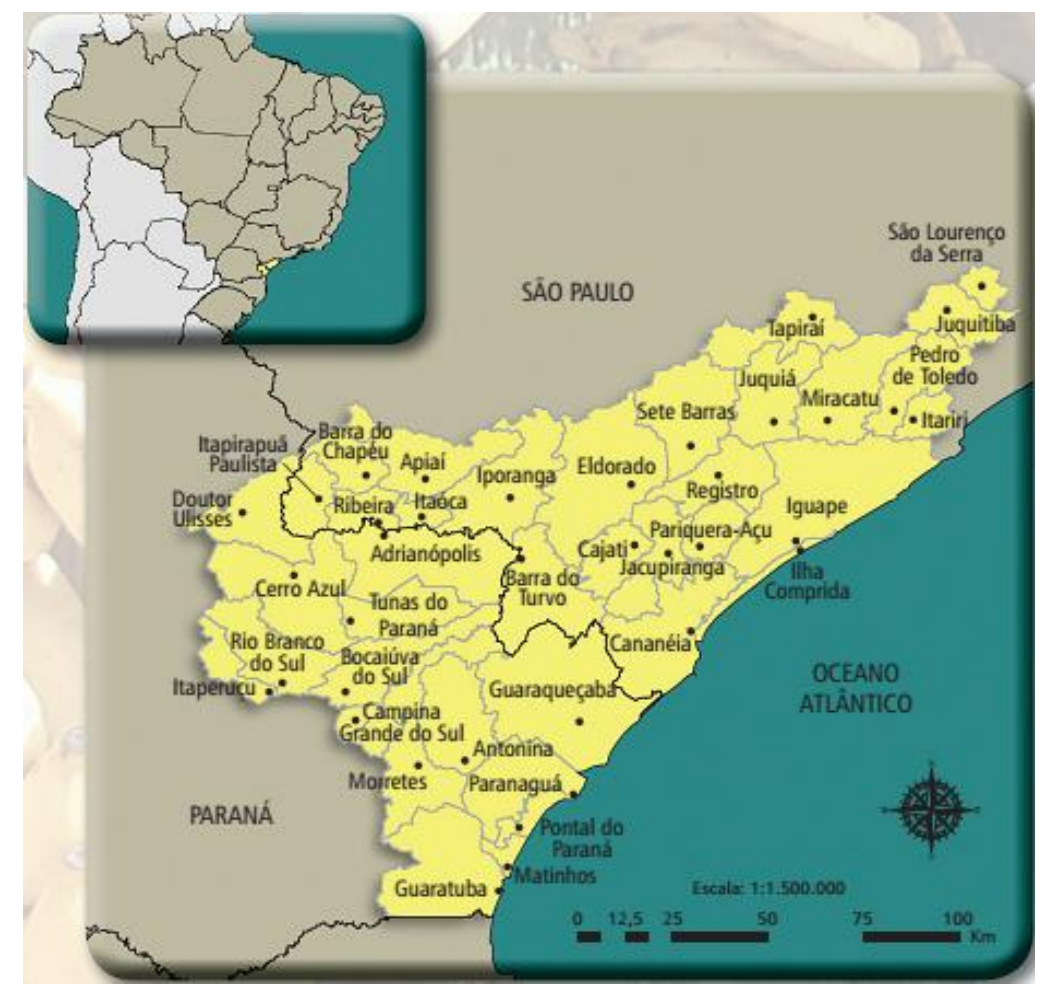

Figura 5.11 - Mapa da Configuração Territorial da Mesorregião do Ribeira/Guaraqueçaba. Fonte: IDESC $(2009)^{45}$.

Além da aproximação com as políticas regionais do MIN, o CONSAD iniciou a integração do Plano VRS com as ações do Comitê de Bacias Hidrográficas do Rio Ribeira de Iguape, que engloba os 23 municípios da porção paulista do Vale. A diferença entre a

\footnotetext{
${ }^{45}$ Disponível em:<http://www.idesc.org.br/arquivos/docs/Plano_PROMESO_VR.pdf>. Acesso em: 17 ján. 2015.
} 
configuração do MDA e a configuração da bacia hidrográfica na sua porção paulista se dá pela ausência dos municípios de Ribeirão Branco e Peruíbe.

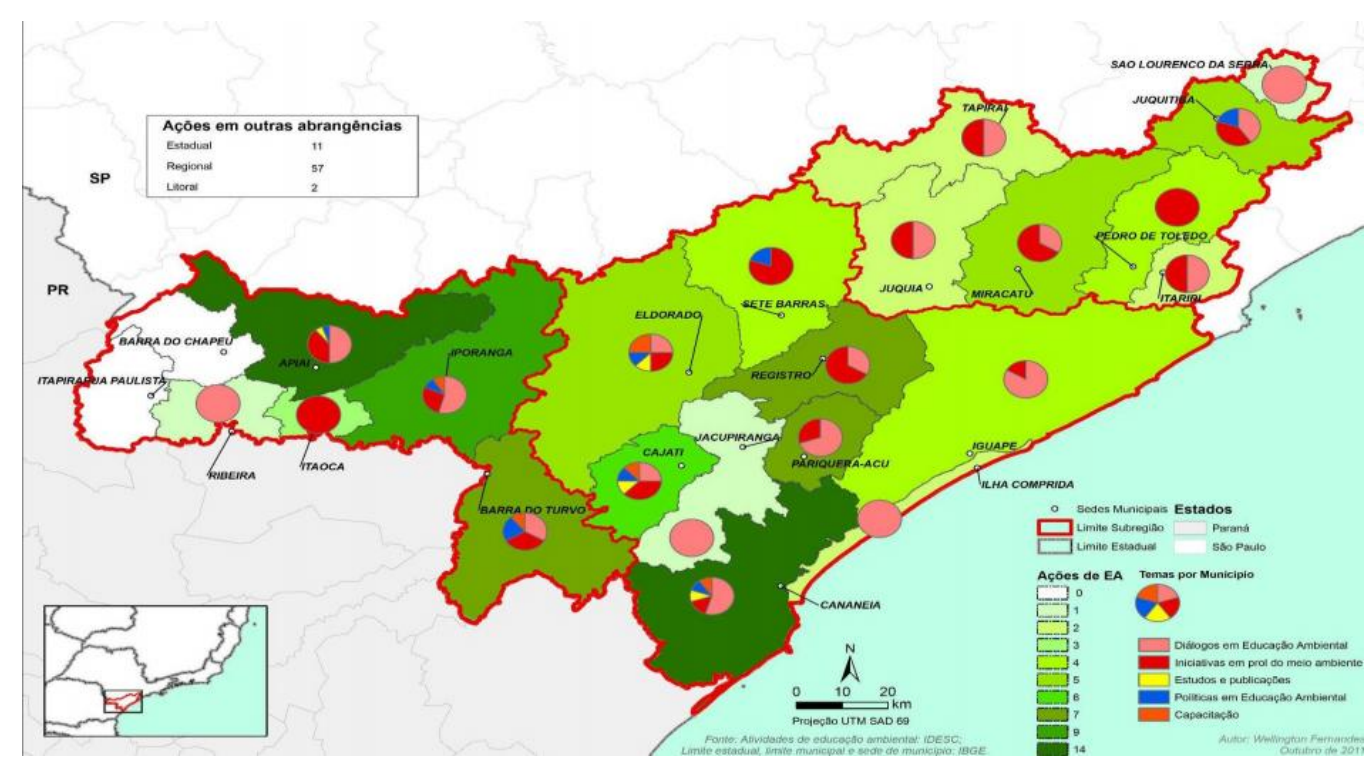

Mapa 5.12 - Configuração da Bacia do Rio Ribeira de Iguape. (Figura ilustrativa) Fonte: IDESC, (2009).

O trabalho de articulação com entes públicos foi reforçado com a realização do Seminário de Pesquisa, realizado na UNESP Registro em 2007, reunindo pesquisadores, organizações não governamentais e órgão públicos que trabalham na geração de conhecimento sobre a região. O Seminário contou com a apresentação de 76 trabalhos e foi considerado como uma estratégia de consolidação de um Centro de Referência em Pesquisa no Vale do Ribeira.

No mesmo ano o IDESC lançou o edital "Vale do Ribeira Sustentável/Agenda $21 \mathrm{n}^{0}$ 01/2007 - Seleção de Propostas para a Implantação de Projetos Socioambientais Prioritárias, em Segunda Chamada". O edital teve como objetivo de promover novas oportunidades a projetos elaborados pelas organizações sem fins lucrativos e empreendimentos produtivos sediados nos 32 municípios, seguindo as linhas temáticas definidas no primeiro edital.

$\mathrm{Na}$ segunda chamada foram encaminhadas 44 propostas por organizações não governamentais de todo o território. De todos estes projetos, apenas 13 foram classificados de acordo com as normas previstas. E destes, oito foram selecionados a aprovação com o financiamento. Isto se deu em função da disponibilidade dos recursos para a segunda chamada. Após a aprovação dos projetos, ocorreram os mesmos procedimentos de divulgação e organização das oficinas de gestão e execução dos projetos, além da formação da equipe que 
acompanharia a gestão financeira e orçamentária dos projetos. Ao todo, entre 2006 e 2007, 22 projetos socioambientais foram aprovados e executados em todo o território abarcado pelo Projeto VRS. O valor total de financiamento dos projetos foi de $\mathrm{R} \$ 203.567,00$ como demonstra a tabela abaixo.

Tabela 5.11 - Projetos socioambientais aprovados entre 2006 e 2007

ASA - Associação Serrana Ambintalista

APIVALE - Associação dos Apicultores do Vale do Ribeira

Associação dos Moradores do Bairro Conchas

IPeC - Instituto de Pesquisas

Associação dos Remanescentes de Quilombos dos Bairros Ribeirão Grande e Terra Seca

Associação dos Remanescentes do Quilombo do Bairro João Surá

COOPERAFLORESTA -Associação dos agricultores Agroflorestais da Barra do Turvo e Adrianópolis

AABM - Associação Amigos dos Bairros de Miracatu

AAPCI - Assoiação de artesãos e produtores caseiros de Iguape

AMAIR - Associação de Monitores Ambientais de Iporanga e Região

\footnotetext{
ÁGUA - Associação de Economia Solidária e Desevolvimento do Bairro Guapiruvu
}

Juquiá - SP

\section{For}

Educação Ambiental na Região do Alto Vale do Iporanga - SP Ribeira, junto às Escolas e Integração Regional no

Desenvolvimento do Ecoturismo

$9.990,50$

9.393, 50 Vale do Ribeira

$\mathbf{8 . 9 6 0 , 5 0}$

Projeto de reflorestamento das áreas degradas, com Cajajti - SP mudas de árvores nativas, e desenvolvimento de atividades socioambientais com a comunidades do Bairro Conchas

$9.898,00$

Cananéia - SP Em cena... Ação! Educomunicação para construção da agenda 21 no município de Cananéia

Fortalecendo o protegonismo das famílias Barra do Turvo agricultores Quilombolas dos bairros Terra Seca e seus direitos, construção de identidade cultural e

$\mathbf{1 0 . 0 0 0 , 0 0}$ desenvolvimento sustentável da comunidade tentativa de suprir a demanda de organização e Adrianópolis - tentativa de suprir a demanda de organização e PR Quilombo João Surá, Adrianópolis, com a abertuta do espaço a realização de projetos.

$9.747,00$

Barra do Turvo Populações Tradicionais Gerando Renda a partir da - SP Recuperação Ambiental da Biodivresidade

$9.240,00$

Projeto "Miracatu Um Novo Destino", com a Miracatu - SP finalidade de mapear o município, cadastrado os atrativos naturais, visando o ecoturimso e esportes de avetura

$9.920,00$

Projeto "Unindo Forças", prevê a mobilização dos Iguape - SP artesãos e o fortalecimento da entidade, realizando cursos sobre "associativismo" e "liderança e motivação"

Projeto "Escola no Parque", que objetiva a inservação de noções básicas sobre meio ambiente junto às comunidades escolares, em especial Iporanga - SP atividades de Educação Ambiental e elaboração da Agenda 21 Escolar

Projeto "Juceará G-30 - Manejo de Juçara", tem como objetivo a organização social de negócios

Sete Barras SP susutentáveis, através do registro legal da Cooperativa Agropecuária de Produtos Sustentáveis do Guapiruvu, com vistas ao licenciamento ambiental das atividades.

Projeto "Educar para Preservar" tem o objetivo elaborar a gestão de resíduos sólidos do Bairro Três Barras. O projeto será realizado em parceria com a prefeitura, que cederá o barracão para as atividade de educação ambiental e reciclagem.
$7.998,00$ 
continuação

Tabela 5.11 - Projetos socioambientais aprovados entre 2006 e 2007

\begin{tabular}{|c|c|c|c|}
\hline $\begin{array}{l}\text { APL - Associação dos Produtores de } \\
\text { leite do Alto Ribeira }\end{array}$ & $\begin{array}{l}\text { Adrianópolis - } \\
\text { PR }\end{array}$ & $\begin{array}{c}\text { Projeto "Viveiro Comunitário" contempla a } \\
\text { implantação e utilização de um viveiro comunitário } \\
\text { de } 500 \mathrm{~m}^{2} \text { para produção de } 100.200 \text { mudas diversas } \\
\text { (olerícolas, frutíferas, florestais nativas e } \\
\text { medicinais) para produção de alimentos, } \\
\text { florestamento e reflorestamento de nascentes e } \\
\text { margens do rio Ribeira de Iguape e seus afluentes, } \\
\text { passando pelos municípios de Adrianópolis, Ribeira, } \\
\text { Itaóca e Tunas do Paraná. }\end{array}$ & $9.700,00$ \\
\hline $\begin{array}{l}\text { AOVALE - Associação dos } \\
\text { produtores orgânicos do Vale do } \\
\text { Ribeira }\end{array}$ & Registro - SP & $\begin{array}{l}\text { "Programa Portal Orgânico" objetiva consolidar a } \\
\text { sustentabilidade econômica aos associados da } \\
\text { AOVALE. Além disto, o programa promoverá feiras } \\
\text { de produtos orgânicos em Registro e Cajati, em } \\
\text { articulação com sindicatos e prefeituras }\end{array}$ & $8.070,00$ \\
\hline $\begin{array}{l}\text { Associação dos remanescentes de } \\
\text { Quilombo do Bairro André Lopes }\end{array}$ & Eldorado - SP & $\begin{array}{c}\text { Projeto "Conservação de Espécie do Palmito Juçara } \\
\text { em Extinção para Fins de Geração de Renda a } \\
\text { Médio e Longo Prazo no Quilombo André Lopes", } \\
\text { projeto integrado ao "Programa do Palmito Juçara } \\
\text { nas Comunidades Quilombolas do Vale do Ribeira" } \\
\text { sob responsabilidade do ISA }\end{array}$ & $9.996,00$ \\
\hline $\begin{array}{l}\text { Associação dos Trabalhadores da } \\
\text { Agricultura do Vale do Ribeira e } \\
\text { Litoral Sul - SINTRAVALE }\end{array}$ & $\begin{array}{l}\text { Barra do Turvo } \\
\text { - SP }\end{array}$ & $\begin{array}{c}\text { Projeto "Educação Ambeintal - Capacitação em } \\
\text { Associativismo" - fomentar a organização social e } \\
\text { desenvolver atividades capacitadoras em educação } \\
\text { socioambiental da comunidade do Bairro Ribeirão } \\
\text { Bonito. }\end{array}$ & $7.830,00$ \\
\hline ARECA - Associação Rede Cananéia & Cananéia - SP & $\begin{array}{l}\text { Projeto "Consolidação da Feira da Agricultura } \\
\text { Familiar em Cananéia, como Espaço para } \\
\text { Comercialização de Produtos Agroecológicos e para } \\
\text { a Conscientização Popular sobre Temas } \\
\text { Socioambientais e Relevância para o } \\
\text { Desenvolvimento Sustentável" }\end{array}$ & $9.980,00$ \\
\hline $\begin{array}{c}\text { ASSTRAF - Associação Sindical dos } \\
\text { Trabalhadores da Agricutura } \\
\text { Familiar na Região do Vale do } \\
\text { Ribeira }\end{array}$ & $\begin{array}{l}\text { Cerro Azul - } \\
\text { PR }\end{array}$ & $\begin{array}{l}\text { Projeto "Desenvolvimento Agroflorestal em Cerro } \\
\text { Azul" - contribuir para o desenvolvimento } \\
\text { agroflorestal a partir da formação e capacitação } \\
\text { processual de agricultores(as) para melho } \\
\text { apropriação dos princípios e conceitos ecológicos } \\
\text { que envolvem esses sistemas }\end{array}$ & $9.963,00$ \\
\hline $\begin{array}{c}\text { Centro de Estudos Ecológicos }+ \text { Gaia } \\
\text { Ambiental }\end{array}$ & Cananéia - SP & $\begin{array}{c}\text { Projeto "Viveiros Agroflorestais da Agricultura } \\
\text { Familiar de Cananéia }\end{array}$ & $9.761,00$ \\
\hline $\begin{array}{c}\text { Colônia de Pescadores Z-7 "Veiga } \\
\text { Miranda }\end{array}$ & Iguape - SP & $\begin{array}{c}\text { Projeto "Campanha Pesca Consciente" - fomentar } \\
\text { as iniciativas e atender as demandas de produção de } \\
\text { mudar nativas, hortaliças, melíferas ornamentais e } \\
\text { plantas medicinais de agricultores familiares em } \\
\text { transição da agrocultura de 'coivara para o sistema } \\
\text { agroecológico. }\end{array}$ & $8.771,00$ \\
\hline $\begin{array}{l}\text { FEPAR - Federação Paranaense das } \\
\text { Associações dos Produtores Rurais }\end{array}$ & $\begin{array}{l}\text { Itaperuçu/Rio } \\
\text { Branco do Sul - } \\
\text { PR }\end{array}$ & $\begin{array}{c}\text { Projeto "Tempo de Cuidar para Semear" - consiste } \\
\text { em atividades teatrais com o reaproveitamento de } \\
\text { rsíduos sólidos como: papelão, jornla, velho, } \\
\text { garrafas plástivas, etc. }\end{array}$ & $\mathbf{8 . 2 4 0 , 0 0}$ \\
\hline $\begin{array}{l}\text { STR - Sindicato dos Trabalhadores } \\
\text { Rurais de Cajati }\end{array}$ & Cajajti - SP & $\begin{array}{l}\text { Projeto "Implantação de Unidades de Experiência } \\
\text { Piloto do Sistema de Fossas Sépticas e conversão da } \\
\text { coleta sanitária em Adubo Orgânico no Município } \\
\text { de Cajati" - prevê a implantação de duas unidades } \\
\text { de sistemas de Fossas Sépticas e a conversão da } \\
\text { coleta sanitária em adubo orgânico, promover o } \\
\text { desenvolvimento sustentável e a preservação da } \\
\text { água com ampla participação da comunidade }\end{array}$ & $10.000,00$ \\
\hline $\begin{array}{l}\text { APOARP - Associação dos Produtores } \\
\text { Orgânicos Auto-Sustentáveis do } \\
\text { Bairro Ribeirão dos Pontes }\end{array}$ & Apiaí - SP & $\begin{array}{l}\text { "Projeto de Implantação de Fosse Séptica } \\
\text { Biodigestora na Comunidades ao Bairro Ribeirão } \\
\text { dos Pontes" - visa oferecer solução de baixo custo } \\
\text { de implantação e custo zero para manutenção, para } \\
\text { resulver o problema do lançamento de esgotos pelos } \\
\text { moradores do Bairro Ribeirão dos Pontes e } \\
\text { associados da APOARP, além de adequar os } \\
\text { agricultores orgânicos à certificação pelo Instituto } \\
\text { Biodinâmico; tecnologia desenvolvida pela } \\
\text { EMBRAPA }\end{array}$ & $9.936,68$ \\
\hline
\end{tabular}

Fontes: IDESC, 2006a; 2007. Organizado pelo autor. 
O processo de construção do Projeto VRS legitimou o colegiado CONSAD como um fórum legítimo de debate, negociação e tomadas de decisões das ações públicas a serem efetuadas e a implementação de políticas públicas. Houve um grande esforço para a articulação entre os diversos fóruns que respondem a três esferas de poder. O CONSAD atuou como proponente e articulador de projetos a partir das verbas de fomento do MDS e do MDA. Serão destacados alguns projetos abaixo:

- Central de Distribuição de Alimentos da Agricultura Familiar, sendo a Prefeitura de Registro o proponente;

- Cadeia Produtiva do Mel, sendo a prefeitura de Apiaí o proponente;

- Projeto de cultivo e repovoamento de palmáceas para a promoção da cidadania, melhoria nutricional, socioeconômica e ambiental das comunidades Quilombolas de Iporanga e Itaóca/SP, aprovado pelo Edital 001/2006 (MDS/SESAN);

- Projeto Saúde e Alimentação na Roça - Envolvendo os municípios de Pedro de Toledo e Miracatu, este projeto tinha como objetivo a melhora da renda e da qualidade alimentar a partir do fortalecimento da cadeia produtiva da mandioca e a recuperação das matas ciliares.

- Projeto de Gestão Solidária de Unidade Produtiva do Beneficiamento de Frutas e Capacitação Regional para a Geração de Renda dos Produtores de Frutas em Cananéia, Ilha Comprida, Iguape e Pariquera-Açu - tendo como executores a prefeitura de Cananéia e a entidade ASA Comunidade ativa, este projeto tinha a intenção de dinamizar a agricultura local.

- Centro Regional em Segurança Alimentar Nutricional Sustentável do Vale do Ribeira - este projeto objetivava a implementação do Plano de Segurança Alimentar e Nutricional nos municípios de Barra do Turvo, Cajati, Eldorado, Jacupiranga, Juquiá, Pariquera-Açu e Registro. A entidade executora deste projeto foi a prefeitura de Jacupiranga.

- Cadeia Produtiva do Mel do Vale do Ribeira - Casa do Mel Ribeirão Branco - este projeto tinha a intenção de construção da infraestrutura para o fortalecimento e escoamento da produção do Alto Ribeira, envolvendo os municípios de Apiaí, Ribeirão Branco, Itaóca, Iporanga, Ribeira, Itapirapuã Paulista e Barra do Chapéu.

- Implementação da Central de Distribuição e Comercialização dos Produtos da Agricultura Familiar do Vale do Ribeira - este projeto foi encaminhado ao edital do PROMESO/MIN e teve como executor a prefeitura de Registro. 
As eleições que ocorreram para a renovação do Conselho Fiscal e do núcleo diretivo para o biênio 2007/2009, foi o pleito eleitoral mais concorrido até então. Todas as cadeiras foram completadas. O presidente eleito foi o prefeito de Apiaí, Donizete Borges Barbosa (PMDB). Os vice-presidentes eleitos foram Valmir dos Santos (micro I), Raul Moreno Calazans, (micro II), Valter Xavier Gomes (micro III) e Antônio Alvarenga (micro IV). A Secretaria Executiva contaria com o então presidente do IDESC, Ronaldo Ribeiro, e a Diretoria Financeira ficaria a cargo da Cláudia Bilche (SEBRAE-SP). Todas as câmaras temáticas (Meio Ambiente e Desenvolvimento, Agricultura Familiar, Segurança Alimentar, Infraestrutura e Turismo) foram preenchidas com 32 membros eleitos, 20 titulares e 12 suplentes (IDESC, 2007).

$\mathrm{Na}$ assembleia de posse da diretoria ocorrida em maio de 2007, Onaur Ruano, então representante da SESAN/MDS afirmou que a as dinâmicas emergidas no colegiado territorial “foi um processo maduro, fraterno, solidário e de alto nível” além do que a "integração (entre ministérios) tem uma relevância, um aspecto importante que torna o Vale do Ribeira uma referência para todo o Brasil” (IDESC, 2007, p. 54). Por causa desta efervescência política que estava ocorrendo na região, ela foi considerada como prioritária para fazer parte dos primeiros 60 Territórios da Cidadania implementados em 2008. Também encontramos na literatura os autores citando o exemplo da experiência no Vale do Ribeira. Em entrevistas realizadas com gestores no âmbito do MDA, Cazella, Bonnal e Maluf (2009, p. 101) são informados, que apesar dos problemas comuns aos territórios, o entrevistado:

"relata exemplos de relações e parcerias "na ponta", como são a articulação de três programas de diferentes ministérios no Vale do Ribeira (SP) [Agenda 21, Consad e Território SDT], os pactos de concertação (como em Lages, SC) construídos com apoio do Ministério do Planejamento, e na atuação com o Ministério de Integração Nacional no Rio São Francisco, em projetos de microcrédito e no direcionamento dos recursos para atividades sustentáveis".

Nota-se que a experiência do CONSAD Vale do Ribeira tomou uma proporção e importância a ponto que naquele momento haviam poucos casos de implementação de políticas territoriais exitosas no contexto brasileiro. Esse processo só foi possível porque pela primeira vez houve uma ação planejada de mobilização dos agentes em torno da construção de um projeto norteador do desenvolvimento da região. Mas o ponto principal é a elaboração de um projeto com amplo caráter participativo e integrador, elevando a experiência ao nível de referencia nacional no aspecto de articulação e mobilização territorial.

No entanto, após a realização das conferências e a implantação dos projetos locais com o financiamento do FNMA, não houve continuidade da implementação do Projeto VRS. O IDESC, principal articulador e mobilizador da região, não renovou o convênio de 
implementação da agenda 21 com o MMA. Entre os anos de 2006 e 2007, a ONG perde três integrantes da equipe de coordenação geral do Projeto VRS: o Coordenador da Meta Monitoramento, a coordenadora da meta Capacitação e o Coordenador Geral e da Meta de Articulação e Parcerias (IDESC, 2006b; 2007). A perda de mais da metade da equipe é um fator crucial para a não renovação do contrato até então formalizado com o MMA, e assim o IDESC deixa a coordenação do Projeto VRS no início de 2008.

\subsection{O Programa Territórios da Cidadania}

O Território da Cidadania Vale do Ribeira (TCVR) foi lançado em 2008 com grande expectativa quanto a sua implementação no meio rural brasileiro. O CONSAD VR foi o colegiado escolhido para ser o instrumento de operacionalização do PTC na região. Esta articulação foi antecipada quando o IDESC ainda era a entidade que coordenava o CONSAD $^{46}$. O ano de 2008 , as reuniões realizadas no âmbito do CONSAD contava com a participação de técnicos da prefeitura. Isso ocorreu por causa do expressivo aumento de verbas para o TCVR. Antes, as verbas repassadas ao CONSAD, giravam em torno de R\$ 150.000 a R \$2.000.000,00 (COELHO; FAVARETO, 2005), agora, os valores liberados na matriz territorial referente a 2008 correspondiam $\mathrm{R} \$ 148.8$ milhões.

Neste montante foram envolvidos 15 ministérios ${ }^{47}$ que elaboraram uma matriz de ações detalhadas em 72 ações dos diferentes ministérios e secretarias ${ }^{48}$.Com o aumento substancial dos repasses e um amplo leque de opções com as ações dos quinze ministérios, em adição às ocorrências de participação da população no CONSAD, previa-se que o Plano VRS seria finalmente executado. Já haviam dezenas de projetos voltados à organização e a criação de alternativas sustentáveis de manejo e conservação, com o objetivo de gerar renda. Contudo, não foi isso que ocorreu. O Plano VRS não foi continuado, porém, as iniciativas começaram a ser executadas segundo o "cardápio de opções" (FAVARETO, 2010b). As informações do

\footnotetext{
${ }^{46}$ Os resultados da implementação do TCVR tem como principal fonte de informação as várias conversas e entrevistas realizadas com a Tania Maria Silva, atual Assessora Técnica Territorial de Gestão Social do Vale do Ribeira.

${ }^{47}$ Casa Civil, Agricultura, Pecuária e Abastecimento, Cidades, Desenvolvimento Agrário, Desenvolvimento Social e Combate a Fome, Educação, Integração Nacional, Justiça Meio Ambiente, Minas e Energia, Planejamento Orçamento e Gestão, Saúde, Trabalho e Emprego, Secretaria Especial da Aquicultura e Pesca, Secretaria Especial de Politicas de Promoção a Igualdade Racial, Secretaria Especial de Políticas para as Mulheres, Secretaria Especial da Presidência da República e Secretaria de Relações Institucionais.

48 CONSAD VR se reúne para discutir Território da Cidadania. Disponível em: $<$ http://www.idesc.org.br/noticias_a_ver.asp?id=95975892\&mes=56\&ano=6>. Acesso em: 16 nov 2014.
} 
relatório de execução disponível no sítio eletrônico do TCVR-SP nos dá um dado de R $\$ 121.9$ milhões executados até dezembro de 2008, ou seja, praticamente $80 \%$ das ações previstas, ou 65 ações em números absolutos, foram executadas. Porém, não há disponibilidade de qualquer relatório de análise sobre as efetividades destas ações.

Em 2009, a verba prevista para a execução de ações foi de R $\$ 152,6$ milhões para 45 ações previstas. Neste ano, os ministérios que disponibilizaram ações foram o MAPA, o MEC, o MS, o MC, o MME, o MDA, o MDS, o MMA e o MTE. De um ano para o outro seis ministérios deixaram de disponibilizar ações na região. Outra coisa, não há disponibilidade de qualquer relatório em relação ás ações executadas a partir de 2009. Tirando o MTE,

Segundo entrevistas com os agricultores familiares e sindicalistas de Registro, em 2009 o PTC já estava deixando de ser atraente, tanto para as organizações e movimentos sociais como para os órgãos públicos. Notamos esta tendência com o quadro das eleições realizadas para o biênio 2009-2011 disponível no sítio eletrônico do IDESC.

Nesta altura da gestão do PTC, percebemos uma mudança na quantidade da representação. Há a ausência de representantes da microrregião do Alto Vale. Outro ponto a ser destacado, é a redução da qualidade de participação. As cadeiras das câmaras temáticas neste pleito são quase que totalmente ocupada por cooperativas de agricultores e sindicatos. A Cooperativa Família do Vale, por exemplo, é o braço operacional do SINTRAVALE e estas duas organizações ocuparam a maioria dos cargos no pleito em questão. Temos também a eleição do prefeito de Apiaí, Emilson Coura da Silva (DEM) para o biênio (Tabela 5.12). 
Tabela 5.12 - Comissão Executiva do CONSAD para o biênio 2009-2011

COMISSÃO EXECUTIVA

\begin{tabular}{|c|c|c|c|}
\hline CARGO & NOME & MUNICÍPIO & ENTIDADE \\
\hline Presidente & Emilson Couras da Silva & Apiaí & Prefeitura Municipal \\
\hline Diretor Financeiro & José Justino Desidério Filho & Registro & Sintravale \\
\hline \multicolumn{4}{|l|}{$\begin{array}{l}\text { Vice Presidente Microrregião } \\
\text { Alto Vale }\end{array}$} \\
\hline $\begin{array}{l}\text { Vice Presidente Microrregião } \\
\text { Eixo-BR }\end{array}$ & Admilson da Cruz & $\begin{array}{c}\text { Barra do } \\
\text { Turvo }\end{array}$ & Câmara Municipal \\
\hline $\begin{array}{l}\text { Vice Presidente Microrregião } \\
\text { Lagamar }\end{array}$ & $\begin{array}{l}\text { Manoel de Oliveira Lisboa } \\
\text { (Nezinho) }\end{array}$ & $\begin{array}{c}\text { Illha } \\
\text { Comprida }\end{array}$ & Prefeitura Municipal \\
\hline $\begin{array}{l}\text { Vice Presidente Microrregião } \\
\text { Portal do Vale }\end{array}$ & Márcio Mansani & Tapiraí & Câmara Municipal \\
\hline \multicolumn{4}{|c|}{ CAMARAS TEMÁTICAS } \\
\hline CAMARA & NOME & MUNICÍPIO & ENTIDADE \\
\hline Agricultura Familiar & Ana Rebeschini & Registro & $\begin{array}{l}\text { Coop. Família do } \\
\text { Vale }\end{array}$ \\
\hline Segurança Alimentar & $\begin{array}{l}\text { Vera Lúcia } \\
\text { Oliveira }\end{array}$ & Sete Barras & Sintravale \\
\hline Turismo & Tarcis Silva & Tapiraí & Sindicato Rural \\
\hline Meio Ambiente e Desenvolvime & $\begin{array}{l}\text { Selma Xavier } \\
\text { Pontes }\end{array}$ & Cananéia & $\begin{array}{l}\text { ASA Comunidade } \\
\text { Ativa }\end{array}$ \\
\hline Infraestrutura & Cláudio Oliveira & Registro & $\begin{array}{c}\text { Programa Luz para } \\
\text { Todoc }\end{array}$ \\
\hline Aquicultura e Pesca & $\begin{array}{l}\text { Diógenes } \\
\text { Carneiro } \\
\end{array}$ & Iguape & $\begin{array}{l}\text { Prefeitura } \\
\text { Municipal } \\
\end{array}$ \\
\hline
\end{tabular}

Fonte: Idesc, 2014. Adaptado pelo autor.

Em 2010 foram disponibilizadas 56 ações dos seguintes ministérios: MAPA, MCT, MEC, MS, MCid, MC, MME, MDA, MDS e MMA. Neste ano, temos somente a inclusão das ações do MCid. O valor total disponibilizado por essas ações foi de R\$166.9 milhões ${ }^{49}$. As verbas executadas foram de R\$ 154.8 milhões, ou seja, mais de 90\% das ações foram executadas.

Apesar dos relatórios afirmarem a disponibilização de verbas nos referidos anos, as mesmas não foram repassadas em sua totalidade. Ao contrário, as verbas foram repassadas de forma intermitente ao longo do tempo. Além disto, os sítios eletrônicos apresentarem dados e

\footnotetext{
${ }^{49}$ Disponível em:

$<$ http://www.territoriosdacidadania.gov.br/dotlrn/clubs/territriosrurais/valedoribeirasp/xowiki/portlets/territorios/ pages/historico_do_programa?sdt_code=100>. Aceso em 15 jan. 2015.
} 
valores diferentes, segundo a assessora técnica territorial, a Matriz do TCVR não foi disponibilizada no ano de 2010 .

O bloqueio da matriz de ações inicia a desmobilização do CONSAD. O colegiado entra no ano de 2011 sem a liberação da Matriz Territorial. As únicas ações efetivas pelo colegiado no período girou em torno da validação do Plano VRS, elaborado durante a implementação do PRONAT, porém ficou somente no papel. Esta validação foi realizada pela Plural Cooperativa, solicitado pelo MDA (MDA, 2010).

O processo de avaliação do Plano VRS ocorreu com as jornadas de qualificação do PTDRS Vale do Ribeira. Essas jornadas ocorreram em dois momentos, em novembro de 2010 e depois em fevereiro de 2011. As jornadas tinham o intuito de avaliar e atualizar as demandas e eixos estratégicos do Projeto VRS num primeiro momento, e qualificar e atualizar o plano escrito num segundo momento. Destas jornadas resultou no relatório Intitulado "Plano Territorial de Desenvolvimento Rural Sustentável Território Vale do Ribeira - Elaborado em 2006 e atualizado em 2011”. Um dos principais resultados deste relatório foi o diagnóstico realizado com a metodologia F.O.F.A. (Forças, Oportunidades, Fraquezas e Ameaças) ${ }^{50}$ que levantou os principais desafios e virtudes do território a partir das seguintes dimensões: i) Ambiental; ii) Político-Institucional; iii) Social, Geográfica e Cultural, e iv) Socioeconômica.

Assim, o Plano VRS passou pelo processo de atualização com participação dos representantes dos órgãos públicos locais. Contudo, não houve esforços para a sua aplicação. Importante ressaltar, o diagnóstico elaborado a partir da metodologia F.O.F.A., indica o Programa Territórios da Cidadania como uma oportunidade. Se por um lado é positiva esta indicação, por outro lado, abordar o PTC como uma oportunidade é uma amostra da não internalização do programa como uma política importante para a região.

O processo eleitoral para o biênio 2012/2013 (Tabela 5.13) se deu num momento de reavaliação do estatuto e da estrutura institucional do CONSAD. Tanto a mobilização regional como a eleição geral ocorreu em novembro deste mesmo ano. Houve um aumento quantitativo na composição da comissão executiva, com a inclusão de um número maior de representantes por microrregião, além do aumento do número de componentes no conselho fiscal, como está na tabela abaixo.

\footnotetext{
${ }^{50}$ A matriz F.O.F.A. ou SWOT em inglês (strengths, weaknesses, opportunities and threats) surgiu na Escola de Negócios de Harvard em 1960. A F.O.F.A. é uma metodologia utilizada no processo de planejamento estratégico empresarial a partir da análise dos pontos fortes e fracos (ambiente interno) e a análise das fraquezas e oportunidades (ambiente externo). Este método visa a organização de problemas e potencialidades de ameaças e oportunidades, permitindo uma visão mais clara dos fatores facilitadores e impeditivos, tanto no ambiente interno como externo. Para saber mais ver Azevedo, (2009).
} 
O novo fôlego tomado pelo CONSAD neste ano se deu principalmente pela articulação da então prefeita de Registro, Sandra Kennedy, como presidente do CONSAD. Neste período, surge um novo obstáculo estrutural no PTC. O presidente da gestão anterior do CONSAD, o ex-prefeito de Apiaí, Emilson Couras da Silva, não efetivou o registro da diretoria eleita em 2011 no cartório. O não registro das atividades de uma organização de direito privado implica no bloqueio das atividades do CONSAD por parte do Tribunal de Contas do Estado. A Sandra Kennedy tentou realizar a prestação e o posterior registro em 2012, porém, sem efetividade. Desde então, não houve mais eleição no CONSAD e os cargos ficaram aberto. Adiciona-se ao processo eleitoral dos municípios que ocorrerou em 2011, onde a Kennedy perderia o seu mandato para o atual prefeito Gilson Fantin (PSDB)

A partir de então, o CONSAD passará a ter reuniões com poucos membros A discussão realizada nas reuniões eram voltadas a dois pontos principais: a reestruturação do colegiado e o uso das verbas federais de infraestrutura (PROINF). E a discussão neste nível de ação não torna possível planejamento que minimamente fortaleça a abordagem territorial. 
Tabela 5.13 - Núcleo Diretivo do CONSAD para o biênio 2011 e 2013.

\begin{tabular}{|c|c|c|c|c|c|c|c|}
\hline \multicolumn{8}{|c|}{ COMISSÃO EXECUTIVA } \\
\hline \multicolumn{8}{|c|}{ Coordenadora Executiva - Sandra Kennedy Viana - Prefeita de Registro } \\
\hline \multicolumn{8}{|c|}{ Secretário Executivo - Fernando Bruno de Martinez Perez - Aquivale de Jacupiranga } \\
\hline \multicolumn{8}{|c|}{ Diretor Financeiro - Ronaldo Rodrigues - Vereador de Apiaí } \\
\hline \multicolumn{4}{|c|}{ MICRORREGIÃO I - Alto vale } & \multicolumn{4}{|c|}{ MICRORREGIÃO II - Eixo-BR } \\
\hline TITULAR & Instituição & SUPLENTE & Ins tituição & TITULAR & Instituição & SUPLENTE & Instituição \\
\hline $\begin{array}{l}\text { Francisco de Assis } \\
\text { Ferrenha Jr - Apiaí }\end{array}$ & $\begin{array}{l}\text { Associação } \\
\text { Morro do Ouro }\end{array}$ & $\begin{array}{l}\text { Wand Marcio } \\
\text { Ribas da Silva - } \\
\text { Apiaí }\end{array}$ & $\begin{array}{c}\text { Sindicato dos } \\
\text { Trabalhadores } \\
\text { Rurais STR }\end{array}$ & $\begin{array}{l}\text { Zenilda Almeida } \\
\text { Carriel- } \\
\text { Jacupiranga }\end{array}$ & $\begin{array}{c}\text { Familia do Vale Cooperativa } \\
\text { \& GT Mulheres }\end{array}$ & $\begin{array}{l}\text { Claudemir José } \\
\text { Marques - Sete } \\
\text { Barras }\end{array}$ & $\begin{array}{c}\text { Cooperativa } \\
\text { Agropecuária de } \\
\text { Produtos Sustentáveis } \\
\text { Guapiruvu - AGUA }\end{array}$ \\
\hline $\begin{array}{l}\text { Odair Batista Sales da } \\
\text { Rocha - Ribeira }\end{array}$ & $\begin{array}{l}\text { Associação dos } \\
\text { Produtores } \\
\text { Orgânicos }\end{array}$ & $\begin{array}{c}\text { Sérgio Lucas } \\
\text { Martins - Itaoca }\end{array}$ & $\begin{array}{l}\text { Associação dos } \\
\text { Produtores } \\
\text { Agropecuaristas }\end{array}$ & $\begin{array}{l}\text { Nilce Ayako } \\
\text { Miashita - Sete } \\
\text { Barras }\end{array}$ & $\begin{array}{l}\text { Chefe executivo prefeitura } \\
\text { municipal }\end{array}$ & $\begin{array}{l}\text { Marcos Rogério } \\
\text { Diniz- Registro }\end{array}$ & $\begin{array}{l}\text { Departamento } \\
\text { Desenvolvimento } \\
\text { Econômico }\end{array}$ \\
\hline $\begin{array}{l}\text { Frederico Dias Batista . } \\
\text { Itaoca }\end{array}$ & $\begin{array}{l}\text { Departamento } \\
\text { agricultura }\end{array}$ & $\begin{array}{l}\text { Alfredo Vieira de } \\
\text { Andrade Filho - } \\
\text { Apiaí }\end{array}$ & $\begin{array}{c}\text { Associação } \\
\text { Produtores } \\
\text { Rurais Lajeado }\end{array}$ & $\begin{array}{c}\text { Claudinei Maciel } \\
\text { - Barra do } \\
\text { Turvo }\end{array}$ & Câmara municipal vereador & $\begin{array}{l}\text { Marcos Portela } \\
\text { - Registro }\end{array}$ & $\begin{array}{l}\text { Câmara municipal } \\
\text { Vereador }\end{array}$ \\
\hline \multicolumn{4}{|c|}{ Conselho Fiscal } & \multicolumn{4}{|c|}{ Conselho Fiscal } \\
\hline TITULAR & Instituição & SUPLENTE & Ins tituição & TITULAR & Institição & SUPLENTE & Instituição \\
\hline $\begin{array}{l}\text { Josias Camargo de } \\
\text { Moraes - Apiaí }\end{array}$ & $\begin{array}{l}\text { Secretaria } \\
\text { Agricultura }\end{array}$ & $\begin{array}{l}\text { Delma Terezinha } \\
\text { R. Fontanese } \\
\text { Apiaí }\end{array}$ & $\begin{array}{l}\text { Departamento } \\
\text { Agricultura }\end{array}$ & $\begin{array}{l}\text { Cristiane Lameu } \\
\text { - Eldorado }\end{array}$ & $\begin{array}{c}\text { Equipe de Articulação e } \\
\text { Assessoria das Comunidades } \\
\text { Negras do Vale do Ribeira - } \\
\text { EACONE }\end{array}$ & & \\
\hline \multicolumn{4}{|c|}{ MICRORREGIÃO III - LAGAMAR } & \multicolumn{3}{|c|}{ MICRORREGIÃO IV - Portal do Vale } & \\
\hline TITULAR & Instituição & SUPLENTE & Instituição & TITULAR & INSTITUIÇÃO & SUPLENTE & INSTITUIÇÃO \\
\hline $\begin{array}{l}\text { Maria Lucia Tescaro } \\
\text { Roma - Peruíbe }\end{array}$ & $\begin{array}{c}\text { Instituto de } \\
\text { Trabalhadores } \\
\text { na } \\
\text { Transformação } \\
\text { da Agricultura } \\
\text { Familiar } \\
\end{array}$ & $\begin{array}{l}\text { Carlos Alberto } \\
\text { Domingues - } \\
\text { Pariquera-Açu }\end{array}$ & $\begin{array}{l}\text { Associação } \\
\text { Vidas Verdes } \\
\text { AVV }\end{array}$ & $\begin{array}{l}\text { Ilso Luiz dos } \\
\text { Santos - Juquiá }\end{array}$ & $\begin{array}{l}\text { Diretor da Agricultura Meio } \\
\text { Ambiente e Turismo }\end{array}$ & & \\
\hline \multirow{2}{*}{$\begin{array}{l}\text { Manoel Fernando de } \\
\text { Oliveira Lisboa - Ilha } \\
\text { Comprida }\end{array}$} & \multirow{2}{*}{$\begin{array}{c}\text { Prefeitura } \\
\text { municipal - Vice } \\
\text { Prefeito }\end{array}$} & \multirow[b]{2}{*}{$\begin{array}{l}\text { Silvano Heck - } \\
\quad \text { Peruíbe }\end{array}$} & \multirow[b]{2}{*}{$\begin{array}{l}\text { CEPE - Colônia } \\
\text { Veneza }\end{array}$} & \multicolumn{2}{|c|}{$\begin{array}{cc}\text { Tarcis da Silva - Associação Princesa Isabel- } \\
\text { Tapiraí } & \text { API } \\
\end{array}$} & & \\
\hline & & & & $\begin{array}{c}\text { Maria } \\
\text { Valdineide da } \\
\text { Silva - Juquiá }\end{array}$ & $\begin{array}{l}\text { Cooperativa dos Produtores } \\
\text { Rurais COPAFARGA }\end{array}$ & $\begin{array}{l}\text { José Alberto } \\
\text { Santos } \\
\text { Nascimento - } \\
\text { Juquiá } \\
\end{array}$ & $\begin{array}{c}\text { Associação de } \\
\text { Produtores Familiares } \\
\text { e Amigos de Bairro }\end{array}$ \\
\hline & \multicolumn{2}{|c|}{ Conselho Fiscal } & \multicolumn{3}{|c|}{ Conselho Fiscal } & & \\
\hline TITULAR & Instituição & SUPLENTE & Instituição & TITULAR & INSTITUIÇÃO & SUPLENTE & INSTITUIÇÃO \\
\hline $\begin{array}{c}\text { Vera Lucia Miller } \\
\text { Bertoli- Pariquera- } \\
\text { Açu }\end{array}$ & $\begin{array}{l}\text { Associação dos } \\
\text { Deficientes } \\
\text { Físicos de } \\
\text { Pariquera-Açu } \\
\text { ADEFIPA }\end{array}$ & & & $\begin{array}{l}\text { Ercias Muniz de } \\
\text { Lima - Juquiá }\end{array}$ & Vereador Câmara municipal & & \\
\hline
\end{tabular}

Fonte: IDESC, 2014. Organizado pelo autor.

Durante o período de implementação do PTC, a maioria das parcerias realizadas ocorreram não surtiram efeito prático no Território Vale do Ribeira. A primeira tentativa de integração foi no âmbito do Plano de Ação da Mesorregião Diferenciada Vales do Ribeira e Guaraqueçaba em 2008. Este plano faz parte do Programa de Promoção da Sustentabilidade de Espaços Sub-regionais (PROMESO) e foi elaborado pela Secretaria de Programas Regionais do MIN. O recorte territorial deste programa tem uma diferença em relação aos planos criados anteriormente, já que abarca um total de 39 municípios, incluindo os municípios do litoral paranaense. No entanto, apesar da tentativa de integração do Projeto VRS e do PROMESO, principalmente com reuniões realizadas em 2009, esta integração não saiu do papel. Pelos dados obtidos da agenda de reuniões disponíveis no sítio eletrônico do IDESC as reuniões do Fórum Mesorregião foram ocorreram de forma mais intensa na porção paranaense do Vale do Ribeira. 
Outra parceria realizada no referido período foi o desenvolvimento da Rede de Defesa e Promoção da Alimentação Saudável, Adequada e Solidária - Rede SANS. A Rede SANS foi criada com a missão de articulação e envolvimento de pessoas e instituições de diferentes contextos para elaborar uma ação articulada de defesa e promoção da alimentação saudável, adequada e solidária. Esta rede resultou de uma articulação entre o projeto executado em parceria pelo Instituto de Biociências da UNESP de Botucatu e o Instituto Harpya (INHAN). Este projeto foi fomentado pela Financiadora de Estudos e Projetos do Ministério da Ciência e Tecnologia (MCTI/FINEP) (REDE SANS, 2012).

O objetivo da Rede SANS é integrar as Politicas de Segurança Alimentar e Nutricional e de Saúde a partir da estratégia de formação de uma rede social voltada a integração, a produção e a difusão de conhecimentos e tecnologias voltadas ao monitoramento nutricional e a promoção da alimentação adequada, saudável e solidária (REDE SANS, 2012).

A operacionalização do projeto se daria pela formação de equipes de animadores locais em 27 municípios de São Paulo. Os municípios escolhidos para implantar o projeto foram Cananéia e Registro, sendo que este último município onde houve o projeto da Rede de fato foi executado. Ao nível político institucional, projeto tinha como escopo integrar os colegiados que tinham como eixo central o tema da segurança alimentar e nutricional, como o Conselho Estadual de Segurança Alimentar (CONSEA-SP) e o Programa Territórios da Cidadania.

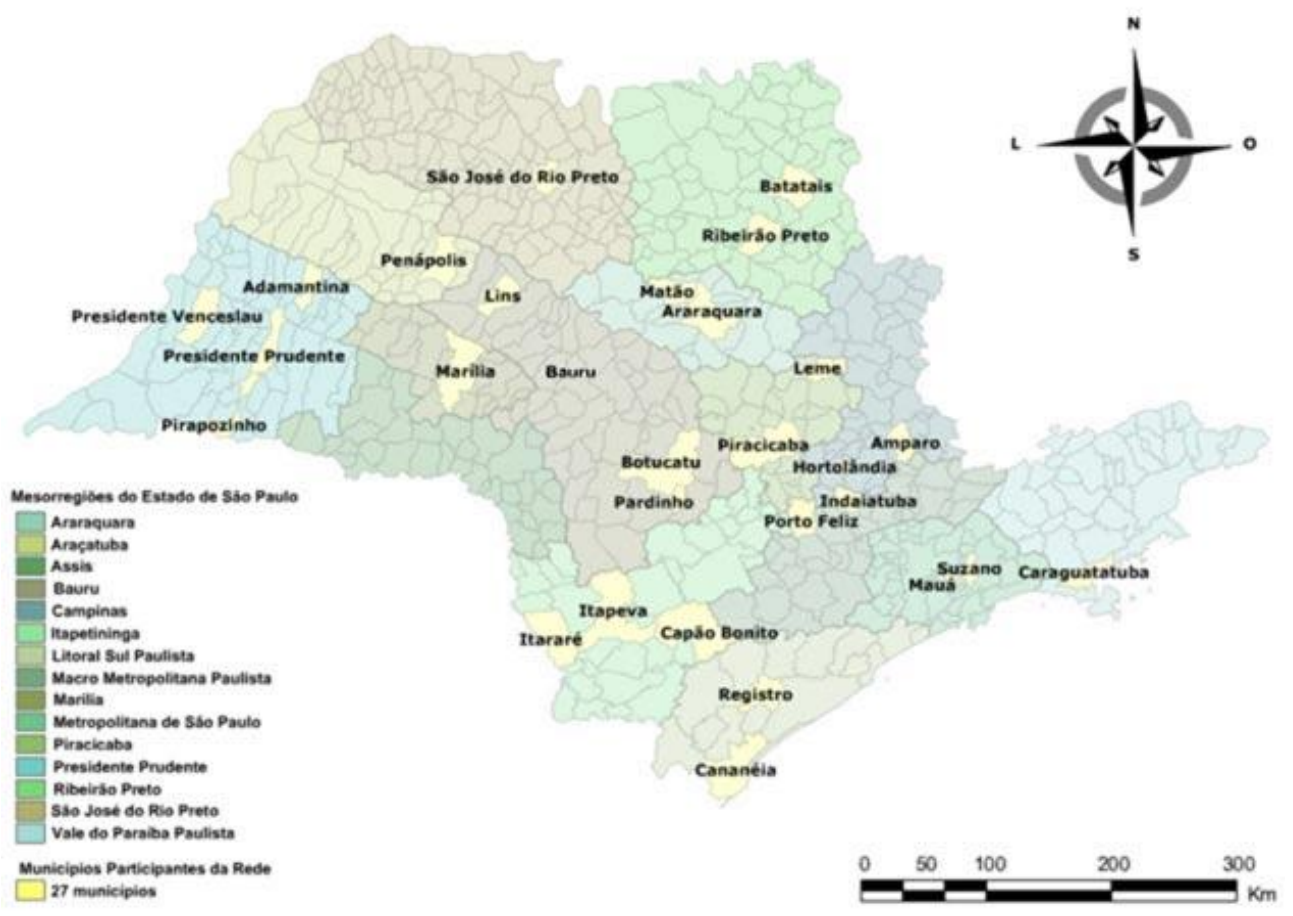

Figura 5.12 - Municípios participantes da Rede SANS. Fonte: Oliveira, Vieira e Galesi (2012). 
As atividades do projeto iniciaram em 2011 com a realização da "1a Conferência Municipal de Segurança Alimentar de Registro: Alimentação Adequada e Saudável ${ }^{51 ” . ~ E s t a ~}$ conferência iniciou os trabalhos da Rede SANS no município. O projeto se concentrou na realização de conferências municipais para difusão da importância da Segurança Alimentar e Nutricional na região, além de trabalhos de informação sobre nutrição em escolas e órgãos de saúde. Até o momento as atividades de promoção da Rede SANS estão ocorrendo no município. Apesar de estar em execução à aproximadamente três anos e ter intensa participação da articuladora de gestão social, não houve suporte financeiro para apoiar as ações da Rede SANS. Os recursos foram disponibilizados com o financiamento do Ministério a Ciência, Tecnologia e Inovação e a Financiadora de Estudos e Projetos - FINEP.

\subsubsection{A burocracia de rua do Programa Territórios da Cidadania Vale do Ribeira}

O Programa Território da Cidadania, foi implementado no meio de um processo de esvaziamento do CONSAD. As reuniões que ocorriam em torno das ações da matriz do Programa não surtiram efeitos práticos. Como não há registros das atas e das memórias das reuniões, houve pouco aprofundamento na análise de quais foram os principais pontos discutidos e as decisões tomadas, principalmente na ausência de informações mais robustas sobre o que ocorreu de fato no CONSAD durante o período. As reuniões específicas relacionadas ao PTC ocorreram em poucos momentos. Foram realizadas quatro reuniões em 2009 e outras duas reuniões foram em 2013.

Mesmo com a ocorrência destas reuniões, os atores não conseguiam direcionar esforços no sentido de estruturar o colegiado, muito menos de planejar qualquer tipo de ação. Além das tentativas furtivas de integração de planos e formação de parcerias entre entes privados e públicos, a gestão do CONSAD, houve um ponto crítico em relação à contratação de recursos humanos para o cargo de assessoria técnica territorial. Pretendemos elencar os principais momentos da experiência da articuladora territorial de gestão social do PTC.

A assessoria territorial foi contratada em 2005 pelo Programa da Terra Assessoria, Pesquisa e Educação Popular no Meio Rural (PROTER). A assessora ficou nesta ONG até o início do ano de 2008, quando ela foi contratada pela Federação da Agricultura Familiar (FAF). Esta organização está ligada ao SINTRAVALE. Em novembro de 2008, a assessora

\footnotetext{
${ }^{51}$ Portal Vale do Ribeira: Segurança Alimentar será tema de Conferência em Registro. Disponível em: $<$ http://www.portalvaledoribeira.com.br/2011/07/29/seguranca-alimentar-sera-tema-de-conferencia-emregistro/>. Acesso em 16 nov. 2014.
} 
tem o seu contrato repassado a Fundação de Estudos agrícolas e Florestais (FETAF). Após o término deste contrato, em outubro de 2009, houve o repasse das contratações do MDA para a Plural cooperativa. Contudo, o repasse foi realizado da somente em novembro de 2010. Entre os meses de novembro de 2009 e agosto de 2010, a assessora trabalhou de forma voluntária no colegiado. Em agosto de 2010, ela consegue um trabalho na Sempre Viva Organização Feminista (SOF). Foi desta organização de onde ela tirava seus rendimentos durante o período, porém, continuava da forma que dava a organizar e participar das reuniões do CONSAD. Geralmente ela dependia de carona de técnicos dos órgãos das prefeituras e estaduais para se locomover na região.

A assessora permanece na SOF até fevereiro de 2011, quando finalmente ela é contratada pela Plural, que de fato havia se conveniado com o MDA para contratação dos consultores territoriais. A contratação pela PLURAL dura apenas oito meses, porque em outubro de 2011 os repasses voltados a manutenção dos contratos entre ministérios e organizações são novamente travados.

Desta vez o bloqueio dos repasses está ligado à Comissão Parlamentar de Inquérito das Organizações não Governamentais, a chamada CPI das ONGs. Essa comissão foi instalada no início de 2007 e tinha o objetivo de apurar a liberação de recursos públicos do Governo Federal para organizações não governamentais (ONGs) e para organizações da sociedade civil de interesse público (OSCIPs), bem como a utilização, por essas entidades, desses recursos e de outros por elas recebidos no exterior ${ }^{52}$. Pelo fato de haver diversas entidades não governamentais atuando no meio rural, sendo que em muitas situações essas ONGs eram financiadas pelo governo federal, muitas entidades tiveram seus trabalhos interrompidos por causa das investigações realizadas no âmbito da CPI.

A comissão se finda em outubro de 2010, contudo o impasse em relação aos contratos e convênios formado entre órgãos públicos e entidades sem fins lucrativos só termina com a publicação do Decreto Federal $n^{0} 7.592$, de 28 de outubro de 2011. Este decreto determina a avaliação de regularidade da execução dos convênios, contratos de repasse e termos de parceria celebrada com entidades privadas sem fins lucrativos. Novamente, entre dezembro de 2011 e setembro de 2012, a assessora consegue ser contratada pela prefeitura de Registro em concomitância ao trabalho realizado no CONSAD. Somente em outubro de 2012 a assessora retorna para a PLURAL. Por sua vez, a PLURAL só retorna as contratações neste período

\footnotetext{
${ }^{52}$ Instituto de Estudos Socioeconômicos - INESC. Chega ao fim a CPI das ONGs no Senado. Disponível em: $<$ http://www.inesc.org.br/noticias/noticias-gerais/2010/novembro/chega-ao-fim-a-cpi-das-ongs-no-senado/>. Acesso em 16 nov 2014.
} 
porque não havia outra organização disponível para tal. Segundo as conversas realizadas com a assessora e outros informantes, a cooperativa não queria mais participar desta modalidade de serviço, porque o MDA não cumpria as regras contratuais. $\mathrm{O}$ ministério evitava registrar a carteira dos assessores. Assim, a PLURAL mantém os contratos e os pagamentos aos assessores até setembro de 2013, quando o contrato da Tania é repassado ao Instituto de Estudos e Assessoria ao Desenvolvimento - CEADES.

Em 2013, houveram duas reuniões no CONSAD Vale do Ribeira. A primeira ocorreu em 29 de outubro no município de Registro e girou em torno da superação dos imbróglios para a reestruturação do CONSAD. Contudo, a discussão realmente ficou restrita a mobilização para execução do PRONATEC e a necessidade de discutir as ações destinadas ao território pela Matriz de Ações. O correto seria discutir a Matriz no mês de janeiro, mas a mesma acabou por ser liberada no final do ano por falta de projetos elaborado por parte das entidades da região.

A outra reunião em questão ocorreu durante um evento de dois dias, 26 e 27 de novembro, no município de Pariquera-Açu. O primeiro dia foi reservado à apresentação do Programa Mais Médicos, contando com a apresentação do programa pela Sandra Kennedy e a participação da maioria dos prefeitos e técnicos municipais. Esta participação tinha um motivo importante, pois na época foram destinados 34 médicos para a região.

No segundo dia da reunião, reservado ao debate da Matriz Territorial, já não tinha a participação dos prefeitos, mas sim, os mesmos técnicos e representantes de organizações sociais que sempre participam das reuniões no CONSAD. Os técnicos e representantes concordaram que a estrutura de dos recursos do MDA é engessada e não possui diretrizes claras para a sua utilização. Além disto, algumas ações que eram mantidas com os recursos alocados pelo ministério foram obrigadas a interromper as atividades devido a intermitência dos repasses. As atividades não são acompanhadas, não há documentos que comprovem o uso efetivo do recurso. Não há avaliação dos projetos executados. E, no caso do TVR, os técnicos observaram a necessidade de resolver os problemas relacionados aos cargos diretivos do CONSAD, que estavam sem representantes desde 2012.

Com o objetivo de encaminhar tanto a reunião como as propostas para serem iniciadas no ano posterior, decidiu-se que: i) organização do pleito eleitoral para o início de 2014; ii) pensar e aplicar um novo modelo de funcionamento do CONSAD; iii) Elaboração dos projetos PROINF em consonância com o Sistema Unificado de Atenção à Sanidade Agropecuária SUASA e iv) aumentar o controle social das ações implementadas pelo PTC, em especial as relacionadas a regularização fundiária. 
Após este debate, foi disponibilizado um informativo com a Matriz Territorial do Vale do Ribeira do ano de 2013. Com este documento em mãos, os participantes discutiam quais seriam as ações a serem territorializadas no ano de 2014. Além disso, havia uma preocupação em torno da matriz territorial de 2013, cujos repasses seriam perdidos caso não houvesse a elaboração de um projeto com abordagem territorial, ou seja, um projeto que integrasse mais de um município tanto na elaboração como na execução.

Logo, munidos do panfleto da matriz territorial, os representantes apontaram algumas ações que eles julgavam necessárias e interessantes de serem puxadas via projetos para o Vale. As ações apontadas estão elencadas na tabela abaixo. As metas territorializadas dizem respeito ao conjunto de ações, cujos recursos já estão definidos para execução. Por outro lado, as metas não terrritorializadas também estão disponíveis para serem implantadas, no entanto, dependerá da elaboração de um projeto territorial para que os recursos sejam acessados. 


\begin{tabular}{|c|c|c|c|c|c|}
\hline Eixo & Ação & Órgão & Meta física prevista & $\begin{array}{l}\text { Valor Previsto } \\
\text { (R\$) }\end{array}$ & $\begin{array}{c}\text { Metas } \\
\text { territorializadas }\end{array}$ \\
\hline $\begin{array}{c}\text { Apoio á } \\
\text { Produção }\end{array}$ & $\begin{array}{l}\text { Disponiblização de Insumos para a } \\
\text { Agricultura Familiar }\end{array}$ & MDA & $\begin{array}{c}\text { Famílias Assistidas: } \\
1.166\end{array}$ & $58.333,33$ & $\operatorname{sim}$ \\
\hline Infraestrutura & $\begin{array}{c}\text { Apoio aos Estados para Implantação do } \\
\text { Cadastro de Terras e Regularização } \\
\text { Fundiária no Brasil }\end{array}$ & MDA & $\begin{array}{l}\text { Imóveis } \\
\text { Georreferenciados: } 6\end{array}$ & $577.066,00$ & $\operatorname{sim}$ \\
\hline $\begin{array}{l}\text { Apoio á } \\
\text { Produção }\end{array}$ & $\begin{array}{c}\text { Assistência Técnica e Extensão Rural para } \\
\text { Agricultores Familiares e seus } \\
\text { Empreendimentos }\end{array}$ & MDA & $\begin{array}{l}\text { Agricultores familiares } \\
\text { assistidos: } 26.042\end{array}$ & $52.083 .266,00$ & não \\
\hline $\begin{array}{c}\text { Apoio á } \\
\text { Produção }\end{array}$ & $\begin{array}{l}\text { Desenvolvimento da Agricultura Orgânica - } \\
\text { Pró-Orgânico }\end{array}$ & MAPA & Territórios Apoiados & $318.000,00$ & não \\
\hline $\begin{array}{c}\text { Apoio á } \\
\text { Produção }\end{array}$ & $\begin{array}{l}\text { Fomento e Fortalecimento de } \\
\text { Empreendimentos Econômicos Solidários } \\
\text { e suas Redes de Cooperação }\end{array}$ & MTE & $\begin{array}{l}\text { Empreendimentos } \\
\text { apoiados: } 6\end{array}$ & $6.000 .000,00$ & não \\
\hline $\begin{array}{c}\text { Cidadania e } \\
\text { Direitos }\end{array}$ & $\begin{array}{c}\text { Concessão de Bolsas de Capacitação e } \\
\text { Formação Profissional em Assistência } \\
\text { Técnica, Pedagógica e social }\end{array}$ & MDA & $\begin{array}{l}\text { Profissionais } \\
\text { capacitados: } 560\end{array}$ & $2.800 .000,00$ & não \\
\hline $\begin{array}{l}\text { Cidadania e } \\
\text { Direitos }\end{array}$ & $\begin{array}{c}\text { Fomento ao Desenvolvimento Local para } \\
\text { Comnunidades Remanescentes } \\
\text { Quilombolas e Outras Comunidades } \\
\text { Tradicionais }\end{array}$ & SEPPIR/PR & Pessoas capacitadas & $1.200 .000,00$ & não \\
\hline $\begin{array}{l}\text { Cidadania e } \\
\text { Direitos }\end{array}$ & $\begin{array}{l}\text { Implantação, Instalação e Modernização de } \\
\text { espaços e Equipamentos Culturais }\end{array}$ & $\mathrm{MinC}$ & $\begin{array}{l}\text { Bibliotecas instaladas } \\
\text { e/ou modernizadas: } \\
110\end{array}$ & $1.372 .934,00$ & não \\
\hline Infraestrutura & Habitação Rural & Mcid & $\begin{array}{c}\text { Operacões para } \\
\text { produção ou reforma } \\
\text { de unidade habitacional } \\
\text { contratados: } 6.709\end{array}$ & $191.209 .920,00$ & não \\
\hline Infraestrutura & $\begin{array}{c}\text { Programa Minha Casa, Minha Vida - } \\
\text { PMCMV }\end{array}$ & MCid & $\begin{array}{l}\text { Unidades habitacionais } \\
\text { produzidas: } 19.267\end{array}$ & $260.695 .000,00$ & não \\
\hline Infraestrutura & $\begin{array}{l}\text { Gestão Ambiental em Projetos de } \\
\text { Assentamento de Reforma Agrária }\end{array}$ & MDA & $\begin{array}{l}\text { Univedades familiares } \\
\text { de produção atendidas } \\
\text { (parcelas): } 359\end{array}$ & $3.588 .874,00$ & não \\
\hline Infraestrutura & $\begin{array}{c}\text { Pagamento de Indeznização Inicial nas } \\
\text { Aquisições de Imóveis Ruraus Para a } \\
\text { Reforma Agrária }\end{array}$ & MDA & $\begin{array}{l}\text { Hectares (há) de áreas } \\
\text { obtidas: } 220.675\end{array}$ & $441.350 .000,00$ & não \\
\hline Infraestrutura & Regularização Fundiária de Imóveis Rurais & MDA & $\begin{array}{l}\text { Imóveis Regularizados: } \\
6.000 \\
\end{array}$ & $3.000 .000,00$ & não \\
\hline
\end{tabular}

Fonte: Informativo Territórios da Cidadania. Maio 2013. Organizado pelo Autor.

Apesar do esforço em debater e apontar metas da matriz de ações para o TCVR, não houve continuidade na proposta da elaboração de um projeto territorial. Em 30 de maio de 2014 ocorreu uma nova reunião no CONSAD. Nesta, os participantes decidiram por fechar o colegiado e implantar uma comissão de coordenação de ações territoriais. Esta comissão seria transitória até a instalação de um Colegiado de Desenvolvimento Territorial (CODETER). A comissão atualmente está formada por dois técnicos do município de Pariquera-Açu, um técnico do ITESP, um técnico do ICMBio, um representante da COOPERAGUA, e o presidente do SINTRAVALE. A decisão de criar um novo colegiado é motivada pelos problemas de operacionalizar a gestão territorial a partir de uma associação de direito privado, 
como era o CONSAD. O CODETER não possui pessoa jurídica, ele é um fórum de articulação para implementação das políticas territoriais. Em julho de 2014, é formada uma cooperação técnica entre o SDT/MDA, o Conselho Nacional de Desenvolvimento Científico e Tecnológico (CNPq) e a Diretoria de Políticas para as Mulheres Rurais (DPMR) para a criação dos Núcleos de Extensão em Desenvolvimento Territorial (NEDET) ${ }^{53}$. Essa cooperação tem o objetivo de dar continuidade a difusão da abordagem territorial a partir das atividades de extensão universitária e pesquisa científica.

Em síntese, o SDT/MDA está repassando a gestão dos programas territoriais para as universidades públicas. No caso do Vale do Ribeira, a universidade responsável ser a UNESP de Presidente Prudente. A equipe técnica territorial prevista para o TCVR é composta por: um coordenador, um estudante bolsista, um assessor técnico territorial de Gestão Social, um assessor técnico territorial de Inclusão Produtiva e um profissional de apoio à participação feminina nos territórios rurais. O TCVR já está se adaptando ao novo arranjo de cooperação tpécnica ente universidades e poder público. Há uma coordenadora da UNESP Presidente Prudente, além da contratação do assessor de inclusão produtiva. Agora os assessores tem um vínculo de bolsistas pelo CNPq. Este valor é repassado diretamente pelo SDT/MDA.

Segundo a Tania, apesar da formação da equipe e as mudanças na forma de contratação, não foram realizadas reuniões para dar início aos trabalhos. A assessora afirma que faltou articulação entre a coordenação do NEDET Vale do Ribeira e a delegacia estadual do MDA para dar início aos trabalhos na região.

\subsection{Considerações sobre as possibilidades e limites dos programas territoriais no Vale do Ribeira}

Na época de execução do PTDRS no Vale do Ribeira, as ações sob responsabilidade do MDA foram importantes na elevação do status da agricultura familiar na região, já que a maior parte dos representantes e dos participantes em geral estavam ligados a este setor (FREITAS; DIAS; FREITAS, 2010). O processo de fortalecimento da SDT ocorrido com o desmembramento das linhas de investimento e custeio e linha de crédito bloqueou a articulação antes realizada pelas diferentes secretarias do MDA (FAVARETO 2010b).

53 CPNq. Chamadas públicas. Disponível em: $<$ http://www.cnpq.br/web/guest/chamadaspublicas?p_p_id=resultadosportlet_WAR_resultadoscnpqportlet_INSTANCE_0ZaM\&id=47-347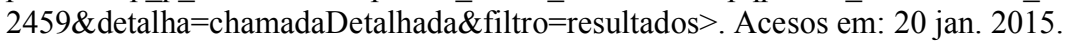 
Por outro lado, o CONSAD careceu da representação de entidades do governo estadual (QUAN, 2008). Tais atores são peças fundamentais para a resolução de problemas estruturais, principalmente ligados ao direito de propriedade, problemas estes que se arrastam à décadas na região. As ações e projetos selecionados ficavam restritos ao setor agrícola, em especial dos agricultores familiares médios ligados à associações e cooperativas. A participação da sociedade civil também se reduz a este público Os municípios foram beneficiados com infraestrutura voltada à melhoria da produção, a implantação de cooperativas agrícolas e turismo rural e em menor medida projetos de educação ambiental (ANJOS et al., 2010; FAVARETO, 2009; FAVARETO, SCHORDER, 2007; LEITE \& WESZ Jr., 2012).

Apesar do desenho institucional dos colegiados permitir uma ampla participação popular no debate relacionado à melhor alocação dos recursos, as decisões ainda são centralizadas na estrutura pública municipal. Ou seja, para encaminhar as iniciativas, depende da disposição política dos prefeitos. Em última instância, as prefeituras decidem quais projetos serão executados, ou podem optar por simplesmente não assinar os projetos. Este é um fator importante num ambiente de constantes tensões político-partidárias (COELHO et al., 2005; COELHO; FAVARETO, 2008).

As ações do CONSAD não construíram um ambiente institucional de aprendizado e criação da perspectiva de longo prazo do desenvolvimento. Ao contrário, a seleção dos projetos era realizada sem critérios claros, não havia avaliação das ações realizadas, e os projetos executados acabavam por não privilegiar outros setores da sociedade (FAVARETO; SCHRODER, 2007).

As analises direcionadas ao CONSAD mostravam que o colegiado é um vetor de promoção da organização da sociedade civil em torno das suas respectivas reivindicações. A própria formação do colegiado, neste caso específico é fruto da pressão exercida pelos movimentos sociais, e inversamente, as estruturas colegiadas se tornam um fator de mudança da identidade dos movimentos, ou seja, há uma retroalimentação entre a sociedade civil organizada e as ações que ocorrem no CONSAD. Porém, não necessariamente há espaço para reivindicações mais amplas. No caso estudado pelos autores, com o foco no conflito em torno da Barragem do Tijuco Alto, fica claro que o CONSAD não possui um ambiente permeável que seja direcionado ao debate deste conflito. (COELHO et al., 2005).

Os colegiados do Vale, em especial o CONSAD, são fóruns de reprodução das estruturas locais de relações assimétricas entre os diferentes públicos. Se por um lado o CONSAD promoveu o fortalecimento da categoria da agricultura familiar, por outro lado, o colegiado desenvolvia ações que não promoviam a complementariedade com outros fóruns e 
ações em andamento na região (COELHO et al., 2005, COELHO et al., 2006). Neste sentido, há a ausência de mecanismos de participação que incluam uma ampla gama de segmentos da sociedade, além da categoria da agricultura familiar. Mesmo com tais limitações, observou-se que o arranjo institucional do CONSAD havia entrado no cotidiano do Vale do Ribeira devido o componente de reprodução dos conflitos político-partidários. O fórum em questão servia como arena de disputa entre os principais partidos atuantes na região, o PSDB, o PMDB e o PT (COELHO et al, 2005).

A análise do arranjo institucional do CONSAD Vale do Ribeira mostra os avanços e limites da implementação do PRONAT. Porém, os autores deixaram de lado um dos objetivos principais do CONSAD na época: a construção do Plano Vale do Ribeira Sustentável. Segundo Galvanese (2009) não houve adesão do plano por parte do governo estadual, devido aos conflitos partidários, já que a composição do IDESC era formada em sua maioria por militantes e líderes regionais do PT. Por outro lado, durante as pesquisas em torno dos conflitos da Barraagem do Tijuco Alto, Coelho (et al, 2005, p. 27), afirmam que "a elaboração do Plano de Desenvolvimento Territorial (do Vale do Ribeira), por sua vez, vem sendo feita através de uma metodologia indubitavelmente competente e cuidadosa".

Desta forma, percebemos que as ações voltadas à elaboração do Projeto VRS foram no seu conjunto a experiência mais efetiva em termos de inovação e planejamento territorial desenvolvida no Vale do Ribeira. Um dos pontos positivos do Projeto VRS foi à ênfase a construção de um planejamento calcado nas necessidades voltadas às satisfações das demandas das organizações de locais. A inovação a ser ressaltada girou em torno da capacidade de organização do CONSAD tanto para a elaboração como para a execução as ações propostas. A primeira medida, de analisar os projetos já existentes e as atividades de identificar as demandas de projetos, foi fundamental para que a coordenação da equipe mobilizadora pudesse direcionar de forma mais efetiva.

A equipe de coordenação do Projeto VRS se preocupou em formar as entidades proponentes com a realização de oficinas de elaboração de projetos em todas as microrregiões. Foram elaborados dois editais de seleção de projetos para execução de demandas prioritárias, fato até então inédito, indo lógica contrária da cultura de "seleção" pelo balcão de projetos (BEDUSCHI; ABRAMOVAY, 2004). Os critérios estabelecidos pelos editais garantiam não somente a qualidade dos projetos aprovados, como mantinham os projetos não aprovados num banco de dados, visando à melhoria e efetivação dos mesmos em futuros processos seletivos. Além disto, a seleção de projetos não era meramente competitiva. O processo de melhoria dos projetos não aprovados evidencia a emergência do aprendizado institucional entre os atores 
participantes. Desta forma, os atores sociais estariam melhorando a sua capacidade de buscar editais públicos e privados para fomento a projetos de organização comunitária e de melhoria da produção agrícola, fundamentada no pilar da sustentabilidade (CALDAS; MOREIRA, 2013).

Além do trabalho de recuperação dos antigos projetos, a execução das atividades de mobilização e a criação de oficinas de elaboração de projetos, além do edital de seleção, o IDESC criou uma equipe de monitoramento dos projetos em execução. Cada centavo dos 23 projetos aprovados entre 2006 e 2007 foram controlados pela equipe de monitoramento e pela coordenação geral do Projeto VRS. Em termos concretos, uma entidade com um projeto aprovado a partir do processo de seleção dos editais, só poderia retirar as verbas relacionadas à execução das ações determinadas pelas metas e objetivos. A verba só era repassada após a comprovação dos recibos de compra, ou da confirmação de um serviço solicitado. Este foi um fator fundamental a prestação de contas de todos os projetos aprovados na época. Todos os projetos foram finalizados sem pendências orçamentárias ${ }^{54}$.

No âmbito do Projeto VRS, as propostas não foram direcionadas somente a agricultura familiar, e muito menos foram restrito as organizações mais estruturadas. Foram aprovados projetos de reflorestamento e educação ambiental, inclusive utilizando dos ferramentais da arte cênica. Alguns projetos também alcançaram comunidades quilombolas no alto vale, associação de produtores artesanais no litoral e até institutos de pesquisas que atuavam na região.Assim, várias regiões mais afastadas do médio Vale foram beneficiadas, a exemplo dos municípios de Apiaí, Iporanga e Barra do Turvo. E mais, as ações executadas foram estendidas até nos municípios do Paraná, como Adrianópolis, Cerro Azul e Ribeirão Branco do Sul.

A organização em torno da construção do Projeto Vale do Ribeira Sustentável, bem como as atividades de elaboração de pequenos projetos voltados à formação organizacional e fortalecimento das lideranças locais, são os mesmos princípios de políticas públicas de Desenvolvimento Territorial implementadas com êxito, a exemplo do Programa Leader (BEDUSCHI; ABRAMOVAY, 2004; GUIMARÃES, 2013).

Este também é um princípio dos técnicos de extensão rural, ou dos agrônomos educadores, na expressão do Mestre Paulo Freire (1983). Para um técnico que atua nesta área, ao encontrar famílias em determinadas situações de desagregação e ausência de organização, a atuação deve ser orientada primeiramente na recuperação do capital social e direcionada a atividades que mais estejam de acordo com superação de determinadas situações de exclusão

\footnotetext{
${ }^{54}$ Informação obtida durante a entrevista realizada com Ocimar Bim, atual técnico da Fundação Florestal e ainda coordenador dos projetos realizados pelo IDESC.
} 
social e impedimento à geração de renda por parte da unidade produtiva. $\mathrm{O}$ apoio técnico e social às famílias estariam ocorrendo em paralelo à elaboração de um plano territorial e a projetos de fortalecimento das atividades produtivas que já se encontram mais estruturadas. Sendo que as intervenções realizadas no âmbito dos técnicos educadores tem base no profundo conhecimento da realidade local, com o intricado objetivo de transformá-la, em conjunto com a transformação das comunidades em verdadeiros sujeitos da transformação de uma dada realidade.

Nota-se que a proposta abordada até o momento converge com um dos pontos centrais da proposta de elaboração do plano regional para o Vale do Ribeira. Segundo as informações do Projeto VRS:

"O Projeto Vale do Ribeira Sustentável, para sua viabilização, estabeleceu como
estratégias de implantação: a ação contínua de mobilização e articulação, pactuação e
fortalecimento das parcerias institucionais; a garantia da participação de todos os
setores e segmentos sociais; a negociação dos consensos e conflitos das propostas. O
estabelecimento de metas em curto prazo (2007), médio prazo (2015) e longo
prazo (2025)". (IDESC, 2006 b, p. 38 , grifo nosso).

Ou seja, os projetos executados tinham coerência com o plano territorial elaborado. As ações de curto prazo serviriam de base para as ações mais estruturantes a serem realizadas no médio e longo prazo, com metas e datas estabelecidas. E de fato, boa parte das metas a curto prazo foram trabalhadas, com exceção da execução do plano.

Portanto, o IDESC e seus membros atuaram como uma verdadeira equipe de burocratas de rua, atuando como o nó de ligação entre os atores sociais e as políticas públicas territoriais (MEYERS; VORSANGER, 2010). Com a promoção da participação dos indivíduos beneficiários do Projeto VRS, o trabalho realizado pela ONG acabou por surtir resultados, mesmo que parciais a nível regional. Os projetos materializaram propostas e temas diversos em diversas localidades da região.

Podemos exemplificar este êxito retornando à página 94 desta dissertação. Nesta página o leitor verá que o quadro relacionado aos valores repassados pelo Programa de Aquisição de Alimentos (PAA) no território Vale do Ribeira tem a Cooperafloresta, a Cooperágua e a Cooperativa Família do Vale como entidades proponentes. Sendo a Família do Vale contém uma expressiva quantia de aproximadamente $1 / 5$ de todo o valor transferido às organizações no Vale do Ribeira entre 2010 e 2014. Somente a Família do Vale já vendeu por volta de um milhão de toneladas de alimentos para o PAA ${ }^{55}$. Importante notar, porém, que a concentração de valores nesta organização reflete em diversas críticas por parte de outras

\footnotetext{
${ }^{55}$ Informação Oral repassada pelo Zezinho, atual presidente do SINTRAVALE e da Cooperativa Família do Vale.
} 
organizações. Outra organização fortalecida durante a experiência de implementação do PRONAT é a Rede Cananéia (ARECA). Esta organização tem o papel de articular 13 associações em torno de elaboração de projetos e a busca de editais públicos e privados. A Rede Cananéia também participa dos diversos colegiados do Vale no sentido de articular as forças públicas nas ações realizadas pela Rede ${ }^{56}$.

Os exemplos ilustrados são poucos quando observamos à riqueza de organizações sociais existentes no Vale. Um último levantamento realizado (COELHO et al, 2005: p.13) mostrou que existem por volta de 210 organizações tais como associações, cooperativas, ONGs, de comercio agrícola, entre outras. Entretanto, torna-se importante ressaltar que, se não houve êxito na execução do projeto territorial no âmbito do CONSAD, este não se deu por falta de mobilização e capacidade de elaboração e execução de ações planejadas por parte dos atores sociais, mas sim pelos diversos problemas apontados acima, que de todas as formas apontam para um intenso conflito político-partidário entre os poderes públicos locais. Este se torna o maior vetor de desagregação de qualquer ação virtuosa a ser promovida na região. Porém, esta assertiva não difere muito de outras experiências regionais realizadas no Vale do Ribeira.

No momento de elaboração do Plano VRS, os autores mantinham um certo otimismo em relação ao fórum. A motivação desta interpretação se dava pela crescente mobilização social na região que havia emergido na década anterior a implementação das políticas públicas territoriais. Por tal fato, haviam uma crença que as organizações locais do Vale poderiam criar tensões constantes que forçariam as estruturas opositoras do desenvolvimento a serem orientadas à gestão democrática e compartilhada dos recursos públicos:

\begin{abstract}
"É perfeitamente possível pensar [...] em cenários nos quais os atores locais venham a mobilizar recursos políticos e institucionais capazes de torná-los mais inclusivos e, ao mesmo tempo, de gerar estímulos e sanções efetivamente voltados para a combinação - mais do que para a confrontação, portanto - dos interesses de atores diversos. Além disso, a forte mobilização social que tem lugar no Vale do Ribeira e que vem contribuindo para aproximar a sociedade local de políticos e ativistas que atuam no contexto nacional e internacional, assim como a entrada em cena de atores ligados a atividades econômicas em ascensão na região, são aspectos que mudam, no médio prazo, as bases das relações entre elementos endógenos e exógenos à realidade local. Isto tende a abrir fissuras nas coalizões de interesses em vigor e nas instituições que respondem pela sua manutenção". (COELHO; FAVARETO, 2008)
\end{abstract}

As críticas são acompanhadas de uma análise propositiva para melhoria das ações no CONSAD, como aponta a necessidade de transformação das políticas territoriais em políticas de governo, e não somente no âmbito de uma secretaria ministerial (KARAM, 2012; GUIMARÃES, 2013). Ademais o fortalecimento dos critérios de complementaridade dos

\footnotetext{
${ }^{56}$ Associação Rede Cananéia. Disponível em: <http://www.redecananeia.org.br/>. Acesso em: 15 jan. 2015.
} 
recursos entre os diferentes ministérios e órgãos públicos, a subsidiariedade, ou a distinção das competências das esferas de poder visando a construção dos mecanismos de enforcement e, ligado aos dois primeiros critérios, a contratualidade em torno dos objetivos fins da política territorial (FAVARETO; SCHRORDER, 2007).

Porém, não podemos deixar de ressaltar a fragilidade de se deixar o planejamento regional ao cargo de uma organização social. Apesar de todos os esforços e êxitos conquistados, as organizações no geral carecem de uma estrutura que alcance a totalidade de uma região ou um público alvo. Dito de outra forma, a estrutura das ONGs tendem a não lograr êxito como atores centrais na implementação de uma determinada política pública. Esta afirmação não diminui a importância dos trabalhos realizados pelas entidades não governamentais. Na maioria dos estudos de casos hoje realizado nas regiões mais afastadas das grandes metrópoles, é quase certo que o pesquisador terá que de se articular com uma ONG local, que geralmente conhece a complexidade sociocultural e ambiental, geralmente fornecendo elementos ao pesquisador que dificilmente seriam obtidos pelo poder público. $\mathrm{Ou}$ seja, este é um aspecto relevante quando se pensa na evidência da atuação dos atores e como esta atuação e suas organizações podem contribuir para a implementação de políticas públicas. Contudo, uma política pública, ou seja, um amplo conjunto de planos e ações direcionados a impactar diversas dimensões da sociedade, só ocorrerá com maior intervenção, de forma planejada, do Estado, isto é, os governos locais, os governos estatais e a União (FREY, 2000; ORTEGA, 2014). O Vale é um claro exemplo desta lógica inversa. Há, de fato mais de 200 organizações sociais, que por outro lado, atuam de forma pulverizada. A diversidade e quantidade de organizações não necessariamente garante ações coordenadas que otimizariam os esforços e produziriam sinergias entre elas.

Em resumo, apesar dos obstáculos observados durante a análise dos resultados desta pesquisa, havia uma aposta na mobilização social do Vale do Ribeira como determinante as reorientações da ação do Estado. Ademais, as recomendações acima são datadas e mostram que na época, os resultados parciais das iniciativas voltadas à promoção da abordagem territorial do desenvolvimento rural seriam explicadas pelo pouco tempo de execução destas políticas públicas (GUIMARÃES, 2013). Ao término da elaboração do Plano VRS, o CONSAD Vale do Ribeira tinha pouco mais de dois anos de vida. Logo, devido aos contextos regionais, havia uma expectativa de que ao longo prazo uma mudança institucional poderia ser alcançada.

Parte destas expectativas estariam relacionadas ao Programa Territórios da Cidadania. Seria este o programa, sob responsabilidade do Ministério da Casa Civil na época, a tornar 
concreta a integração entre os ministérios, incluindo as esferas Estaduais e Municipais. O amplo leque de ações promoveria não somente a redução das assimetrias sociais nas regiões e territórios mais deprimidos com as políticas sociais, mas também induziria os territórios ao Desenvolvimento Territorial Rural Sustentável, com ampla participação popular. O programa viria com uma roupagem inovadora, dentro das perspectivas e avaliações dos programas anteriores que já estavam sendo geradas pelos estudiosos.

Porém, o PTC no Vale do Ribeira não cumpriu com as expectativas criadas. $\mathrm{O}$ contexto analítico nos faz ressaltar os fatores que culminaram na não implementação do PTC. O fato da renovação não ter ocorrido tem parte da explicação saída de metade da equipe de coordenação do IDESC. Em meados de 2007, a coordenadora de capacitação da época Sandra Kennedy se torna candidata ao cargo da prefeitura de Registro pelo seu partido de filiação, o PT. Junto com ela, o Ronaldo Ribeiro sai da Coordenação geral do Projeto VRS para coordenar a campanha da então candidata, que se tornaria prefeita da cidade no ano posterior. Este momento culmina com a saída do IDESC da coordenação do Projeto Vale do Ribeira Sustentável.

O resultado do processo eleitoral municipal ocorrido em 2007 foi outro impedimento ao efetivo uso do colegiado e da impulsão das ações territoriais. O impacto político decorrente da vitória de Sandra Kennedy para o cargo de prefeita da principal cidade da região reagiu de forma negativa por parte do pode público local. Muitos acabaram por ver o CONSAD como um espaço privilegiado do PT. Além deste fato, temos que ter em mente que houve mudança em todo pleito municipal na região. Se no início do projeto houve a participação simbólica de alguns prefeitos, a partir do pleito de 2008 este fato é totalmente alterado. A participação no âmbito do PTC só ocorreu no início, pelo entusiasmo geral pelo aumento de verbas do governo federal, que, contudo, foi perdendo o interesse no decorrer do tempo.

A ocorrência de um processo eleitoral realizado a cada dois anos é um dos principais desestabilizadores das políticas públicas em andamento. Esse é a principal reclamação por parte da maioria dos gestores públicos entrevistados durante a elaboração desta pesquisa. E cada vez mais, devido à ampla e ignorante polarização partidária, aliado ao fraco sistema político e eleitoral, dependente da governabilidade e relações corruptas e escusas, o processo eleitoral acaba se tornando um amplo campo de disputa de poder, o que ocorre em detrimento da efetividade da já contestada gestão pública brasileira (CALDAS; MOREIRA, 2013).

Por outro lado, boa parte dos técnicos e representantes públicos, de todas as esferas de poder, se tornam verdadeiros cabos eleitorais. Desta forma, os conflitos partidários acabam refletindo diretamente na forma que os gestores públicos operacionalizam as políticas 
públicas. Este condicionamento ideológico parece ser um dos principais entraves a uma atuação discricionária por parte dos gestores públicos (MEYERS; VORSANGER, 2010). Se por um lado o conteúdo político dissemina abordagem territorial e a cooperação entre os entes federados e entidades públicas e privados, por outro lado, o “jogo das regras" (COELHO et al., 2005 , p. 32) enraizadas historicamente no processo político brasileiro atua como um dos fatores impeditivos para a melhor efetividade e cooperação na gestão pública.

Vale ressaltar elevado nível de competência técnica dos gestores locais. Os técnicos e gestores entrevistados demonstravam relevante experiência e uma longa história de atuação como servidor público no território estudado, além de serem servidos de ideias inovadoras quanto às possibilidades de desenvolvimento da região. Apesar da pouca quantidade de servidores públicos, ao menos o problema não parece ser o de capacitação e conhecimento destes, pelo contrário, muitos falam do potencial agroecológico que a região possui, bem como, mencionam a baixa capacitação em geral da população e ausência de tecnologia de ponta para produção agrícola orgânica adaptada ao Vale. Por outro lado, este é um ponto que só reforça o quadro de conflitos políticos reproduzidos, já que não é a ausência de conhecimento ou de propostas e alternativas a promover o desenvolvimento no Vale, mas sim a excessiva atuação da agenda política em detrimento da promoção de políticas públicas que façam emergir a inclusão social e o desenvolvimento com os princípios da sustentabilidade (MEYERS; VORSANGER, 2010).

A mobilização em torno da composição da diretoria e comissão executiva do CONSAD para o biênio 2011-2013 foi fortemente influenciada pela então prefeita de Registro. Neste ponto, surgiram algumas dúvidas. Se a região é tem na maioria das prefeituras compostas por partidos coligados ao PSDB, e pelo fato do acirramento dos conflitos em relação à eleição do PT na cidade de Registro, como houve esta mobilização para a diretoria e comissão executiva em 2011? Resolvemos buscar essa informação dos prefeitos eleitos no território entre 2004 e 2008 , e o resultado está no quadro abaixo. 
Tabela 5.15 - Prefeitos eleitos no Território Vale do Ribeira

\begin{tabular}{|c|c|c|c|c|}
\hline & \multicolumn{2}{|l|}{2004} & \multicolumn{2}{|l|}{2008} \\
\hline Município & Candidato eleito & Partido & Candidato eleito & partido \\
\hline$\overline{\text { Apiaí }}$ & DONIZETTI BORGES BARBOSA & PMDB & EMILSON COURAS DA SILVA & DEM \\
\hline Barra do Chapéu & MARIA ANUNCIATA DA SILVA LEME & PSDB & EDUARDO VICENTE VALETE FILLIETA & PMDB \\
\hline Barra do Turvo & FAUSTO COMPER & PDT & ROSÂNGELA ROSÁRIA DA SILVA & PRB \\
\hline Cajati & MARINO DE LIMA & PMDB & LUIZ HENRIQUE KOGA & PSDB \\
\hline Cananéia & GERALDO CARLOS CARNEIRO FILHO & PMDB & ADRIANO CESAR DIAS & PSDB \\
\hline Eldorado & ELOI FOUQUET & PSDB & DONIZETE ANTONIO DE OLIVEIRA & РTB \\
\hline Iguape & ARIOVALDO TRIGO TEIXEIRA & PMDB & MARIA ELIZABETH NEGRÃO SILVA & PP \\
\hline Ilha Comprida & ANTONIO MARCIO RAGNI DE CASTR( & ( PSDB & DÉCIO JOSÉ VENTURA & PSDB \\
\hline Iporanga & ARIOVALDO DA SILVA PEREIRA & PMDB & ARIOVALDO DA SILVA PEREIRA & DEM \\
\hline Itaóca & ALUIZIO RIBAS DE ANDRADE & PFL & ALUIZIO RIBAS DE ANDRADE & DEM \\
\hline Itapirapuã Paulista & LUIZ GONZAGA DIAS SOBRINHO & PT & LUIZ GONZAGA DIAS SOBRINHO & PT \\
\hline Itarini & DANIEL JOAQUIM SILVA & PP & DINAMERICO GONÇALVES PERONI & PSDB \\
\hline Jacupiranga & JOÃO BATISTA DE ANDRADE & PT & JOÃO BATISTA DE ANDRADE & PT \\
\hline Juquiá & MANOEL SOARES DA COSTA FILHO & PMDB & MOHSEN HOJEIJE & PTB \\
\hline Juquitiba & ROBERTO SILVAL ROCHA & PSDB & MARIA APARECIDA MASCHIO PIRES & PDT \\
\hline Miracatu & MIYOJI KAYO & PSDB & DÉA FÁTIMA VIANA LEITE MOREIRA I & I PSDB \\
\hline Pariquera-Açu & ZILDO WACH & PSL & ZILDO WACH & DEM \\
\hline Pedro de Toledo & EULÁLIO ILEK & PTB & SERGIO YASUSHI MIYASHIRO & PSB \\
\hline Peruíbe & JOSÉ ROBERTO PRETO & PTB & MILENA XISTO BARGIERI MIGLIARESI & IPSB \\
\hline Registro & CLOVIS VIEIRA MENDES & PMDB & SANDRA KENNEDY VIANA & PT \\
\hline Ribeira & JONAS DIAS BATISTA & PSDB & GIDIONI DE OLIVEIRA MACEDO & PT \\
\hline Ribeirão Branco & SANDRO ROGÉRIO SALA & PT & SANDRO ROGERIO SALA & PT \\
\hline São Lourenço da Sen & JOSÉ MERLI & PSDB & LENER DO NASCIMENTO RIBEIRO & DEM \\
\hline Sete Barras & ADEMIR KABATA & PFL & NILCE AYAKO MIASHITA & PR \\
\hline Tapiraí & ALVINO GUILHERME MARZEUSKI & PSDB & ALVINO GUILHERME MARZEUSKI & PSDB \\
\hline
\end{tabular}

Fonte: Tribunal Superior Eleitoral, 2015. Organizado por: Joaquim Júnior

O quadro demonstra com clareza que foram eleitos mais prefeitos pelo PT em 2008 quando comparamos com os prefeitos eleitos em 2004. Neste dado momento, a prefeita se esforçou novamente para mobilizar os atores locais. A tabela 5.13 (página 145) mostra que a maior parte da composição do CONSAD no biênio 2011-2013 tinha simpatizantes e líderes políticos da mesma coalizão, à exceção dos municípios de Itapirapuã Paulista e Ribeirão Branco. Houve composição até por boa parte de representantes do DEM e do PTB, o que mostra um pouco da enorme complexidade em compreender como se dão as alianças políticas entre os partidos políticos. Em resumo, essas contingências foram favoráveis a uma nova tentativa de mobilização em torno do CONSAD.

Entretanto, a impossibilidade de registro da diretoria eleita por problemas não resolvidos na gestão anterior presidido por Emilson Couras acabou por desmobilizar o poder público local em torno do colegiado. Ainda houve uma tentativa da prefeita em realizar o registro no cartório em 2012, porém, o Tribunal de Contas do Estado manteve o colegiado impedido de realizar suas funções pelo não registro da diretoria que compôs as cadeiras na gestão anterior.

Por último, temos o fator que ilustra como se dá a relação entre os formuladores da política pública e os burocratas que a executam. Neste caso, da relação entre a SDT/MDA e os 
assessores territoriais. Há um descaso por parte da secretaria em relação às condições de trabalho da consultora territorial. A precariedade das contratações dos assessores territoriais passa pela terceirização e resistência ao registro em carteira. Além disso, não há estrutura mínima do programa no Território em tela. Geralmente são usados espaços cedidos por prefeituras ou organizações atuantes na região. A assessora não possui nenhum meio de locomoção garantido, o que a faz depender de caronas de técnicos de órgãos municipais e estaduais para a sua locomoção e acompanhamento das reuniões. Em diversos momentos a assessora trabalhou de forma voluntária e não foi ressarcida dos meses trabalhados de graça.

Uma das funções da assessora é produzir relatórios sobre todas as atividades que ela participa que estão relacionadas a gestão do TCVR. Nunca houve retorno por parte do MDA em relação aos relatórios produzidos. Além disto, os mesmos deveriam ser publicados no sítio eletrônico do programa, o que também nunca ocorreu. Não há qualquer instrumento de avaliação das verbas repassadas aos municípios. Atualmente, não há nenhuma necessidade de apresentar projetos, os repasses já são direcionados as prefeituras, sem qualquer proposição. Claramente houve um recrudescimento quando comparamos aos planejamentos minimamente estruturados pelo PRONAT (FAVARETO, 2009).

As poucas reuniões realizadas no CONSAD durante o período se limitaram ao debate da reestruturação do colegiado, às tentativas de fortalecimento dos mecanismos de participação popular, e, no máximo, a discussão direcionada ao encaminhamento do Programa Nacional de Infraestrutura - PROINF. Com exceção da reunião de apresentação do Programa Mais Médicos, as reuniões do CONSAD seguiam a mesma tônica, geralmente composta pelos mesmos técnicos e representantes da sociedade civil. Desta forma, fica clara a ausência de uma representatividade mais expressiva do conjunto das forças vidas do território que se organizam , bem como há a ausência de influência por parte do colegiado na tomada de decisão dos recursos repassados pelas políticas (ABRAMOVAY, MAGALHÃES, SCHORDER, 2010).

Assim, o ciclo de vida da "Associação" Consórcio de Segurança Alimentar e Desenvolvimento Local do Vale do Ribeira - CONSAD-VR - foi finalizado com o fechamento do mesmo ocorrido em meados de 2014. Contudo, a estrutura de gestão do Programa Territórios da Cidadania foi repassada às universidades públicas. O MDA continua responsável pelo programa, porém, agora será somente o financiador do mesmo, repassando as atividades de gestão para as instituições de ensino. A pauta de participação das universidades nos colegiados era constantemente mencionada pelos gestores entrevistados durante esta 
pesquisa, e como a UNESP de Presidente Prudente possui experiência na área da extensão rural, esta articulação pode se tornar um fator positivo para o território em tela.

Logo, se esperávamos um programa distribuindo "cardápios de ações", ou a reprodução da prática do "mais do mesmo", nem esses efeitos foram observados. Ao compararmos com a época do início da implementação das políticas territoriais, a abordagem inovadora fora amplamente disseminada, mesmo que de forma normativa (FAVARETO, 2010A), hoje a abordagem simplesmente sumiu do discurso nas reuniões e encontros regionais (CALDAS; MOREIRA, 2013; FAVARETO, 2010b; GUIMARÃES, 2013; LOTTA; FAVARETO, 2013; KARAM, 2012; MONTENEGRO GÓMEZ; FAVARO, 2012). Poucas foram as entrevistas nas quais os gestores apontavam ou discutiam o enfoque territorial. Atualmente, o discurso que se mantém ativo é o do fortalecimento da agricultura familiar na região. Não que este fato não seja importante, dada a grande massa de agricultores familiares da região, os bananicultores em especial. Entretanto o debate sobre a construção de um plano de Desenvolvimento Territorial simplesmente não ocorre.

A única exceção, da qual houve oportunidade de participação, foi a III Conferência de Economia Solidária do Vale do Ribeira, que ocorreu em abril de 2014 na cidade de Registro. O objetivo da conferência girava em torno do levantamento de demandas possíveis de serem realizadas pelo governo federal para a promoção da Economia Solidária na região. Além disso, a conferência iria eleger os delegados para a Conferência Estadual que ocorreria posteriormente. Durante a reunião, uma das questões mais ressaltadas foi a necessidade de articulação das diferentes organizações, bem como a elaboração de um plano regional de economia solidária. Contudo, o Plano VRS, que já existe, não foi citado durante todo o evento.

Por fim, a implementação do PBSM é um marco da agenda de combate à fome, ocorrendo, porém, em detrimento dos programas que promoviam a abordagem territorial (FAVARETO, 2010b). Tendo em mente que se por um lado os temas definidos em agendas públicas são escassos frente à totalidade dos temas a serem problematizados e executados em termos de políticas públicas (CAPELLA 2006; KINGDON, 2006), por outro percebemos que a não integração da agenda territorial resultou em efeitos negativos para a população do meio rural, pela ausência dos debates que promovam as alterações estruturais para a melhoria da qualidade de vida das populações menos dotadas dos capitais simbólicos e materiais (ZIMMERMANN et al., 2014).

Importante ressaltar que apesar dos resultados evidenciados nesta dissertação em torno dos limites de alcance das políticas territoriais no Vale do Ribeira não representam a riqueza 
de experiências locais de êxito. A falta de expressão das forças sociais no CONSAD não corresponde á ausência de dinâmicas socioeconômicas virtuosas, mas demonstra que as políticas territoriais em questão não possuem no momento atual incentivos suficiente que faça os atores sociais do Vale apostarem suas fichas no CONSAD. 


\section{CONCLUSÃO}

O objetivo que orientou a dissertação foi identificar os desafios e as perspectivas das políticas públicas territoriais, o programa Nacional de Desenvolvimento Sustentável dos Territórios Rurais (PRONAT) e o Programa Territórios da Cidadania, ambos implementados no Território Vale do Ribeira. O argumento central que norteou nossos objetivos era que os vários projetos e políticas implementadas no Vale do Ribeira ao longo do último século, bem como os projetos territoriais de desenvolvimento, pecaram pela não emergência do desenvolvimento inclusivo e baseado nos princípios da sustentabilidade.

O capítulo 2 foi apreendemos a emergência da agricultura familiar na década de 90 como categoria analítica voltada ao desenvolvimento de pesquisas científicas. Á luz da consolidação desta abordagem, foram implementadas políticas públicas para dinamizar as regiões rurais brasileiras, em especial as ações de credito ao agricultor familiar e os projetos de reassentamento de família sem terras. Por outro lado, a influência de experiências internacionais inovadoras quanto o planejamento de políticas públicas voltadas ao meio rural, fizeram reacender o debate do planejamento regional no país, a partir do enfoque territorial como categoria reguladora e orientadora ações públicas. Assim, consolida-se a agenda governamental de contínua maturação A abordagem dos fluxos e da formulação da agenda identificou os caminhos trilhados pelos precursores da abordagem territorial durante a década de 1990, bem como a sua materialização na agenda governamental quando ocorreu a mudança de governo brasileiro no início deste milênio.

No capítulo 3, temos a articulação dos conceitos que abordam o campo das políticas públicas, ou, o enfoque analítico do governo em ação. A análise da política pública compreende as formas das tomadas de decisões, como elas são formuladas e implementadas. Porém, as negociações e dos conflitos em torno da execução das políticas, e a dimensão institucional, são as variáveis explicativas para identificar o grau de efetividade do conteúdo, ou, da política pública executada. Em complementaridade a análise da política pública, o modelo dos ciclos da política pública tem a função de organizar e sistematizar o ciclo de vida de uma política. Já o modelo da implementação da política pública reserva atenção ao momento que as formulações serão executadas. Pela implementação da politica, estende-se o olhar direcionado e esclarecer os limites e perspectivas da realidade política. A perspectiva ascendente, ou de baixo pra cima, possui elementos de compreensão de como a política pública é aplicada na realidade, onde os burocratas de rua e a sociedade moldam e são moldados pelas ações formuladas pelos tomadores de decisão. 
No capítulo 4, buscamos compreender, a partir da revisão da literatura, os marcos normativos das políticas públicas de Desenvolvimento Territorial Rural. Elaboramos uma breve análise dos efeitos gerados durante a implementação do Programa Nacional de Desenvolvimento dos Territórios Rurais (PRONAT) em 2003, e percebemos que, no que pese os limites do viés setorial e o foco no público da agricultura familiar, o PRONAT cumpriu o importante papel de ampliar a importância dos agricultores familiares e a aproximação entre este público e a gestão pública de forma mais intensa. Outro ponto importante, criou-se um espaço de aprendizagem entre conhecimento tácito e técnico, que elevou consideravelmente a capacitação das organizações sociais.

Os limites do PRONAT seriam trabalhados com a implementação do Programa Territórios da Cidadania (PTC) em 2008. A proposta de universalização das políticas sociais e direitos básicos da cidadania, aliado ao reforço dos princípios da articulação e cooperação na gestão pública orientada ao Desenvolvimento Territorial Rural Sustentável, surge com a implementação do programa grandes expectativas quanto a mitigação das históricas mazelas sociais.

A proposta de ampla integração dos setores e órgãos públicos, visando a redução da pobreza aliada a promoção de círculos virtuosos de desenvolvimento no campo não foi alcançada na maioria dos casos levantados nesta dissertação. Foi possível perceber que entre os casos estudados e as análises normativas, o PTC em geral não logrou os objetivos propostos a poucas exceções de regiões com o histórico de desenvolvimento socioeconômico consolidado. O programa não integrou as ações entre os ministérios, tampouco estimulou a coordenação e cooperação entre entes das esferas subnacionais e municipais. A gestão do programa se deu a partir de ações disponibilizadas de forma dispersa, e recrudesceu as poucas inovações e êxitos obtidos pelo PRONAT.

No capítulo 5 há a elaboração de um breve retrato do Território Vale do Ribeira. As contingências geográficas e populacionais resultaram na preservação de uma riqueza sociocultural e ecológica única, porém, riqueza esta explorada e gerida de forma equivocada tanto pela população local como pelos órgãos públicos atuantes na região. O Vale vem alterando a composição dos setores econômicos, onde a importância do setor de serviços cresce em importância, entretanto, mantendo a agricultura como um importante setor de composição econômica. Apesar da heterogeneidade e diversificação das atividades produtivas, esta se dá de forma desigual, sendo concentrada principalmente nos municípios mais dinâmicos como Registro e Cajati. Com exceção da comercialização de poucas 
variedades agrícolas, em especial a banana, com um conjunto exíguo e disperso de industrias, no geral a dinâmica econômica no Vale do Ribeira é estritamente regional.

As ações públicas implantadas na região, principalmente no século XX se deu de forma intermitente e com poucas exceções foram voltadas para as comunidades mais pobres. Muito pelo contrário, a maioria das ações estatais implantadas na região promoveram o aumento da disparidade social e a degradação ambiental. Os conflitos causados pela ocupação de grileiros e terceiros, bem como a instituição de UCs motivaram a intensificação do conflito pela posse da terra e pelo direito de reprodução dos ritos e costumes tradicionais.

Se por um lado havia um ambiente de espoliação e relações assimétricas entre poder público e as comunidades de agricultores familiares e comunidades tradicionais, por outro lado, este foi o estopim para o surgimento de diversos movimentos sociais da região. Estes movimentos tiveram forte influencia das comunidades católicas, partidos políticos e sindicatos rurais.

A reabertura a um sistema democrático no Brasil foi fundamental para a ampliação das organizações da sociedade civil aumentarem o poder de influência nas tomadas de decisões dos governos. No Vale do Ribeira este processo se deu com mais intensidade, devido à gestão do governador Franco Montoro, e pelas diversas organizações que surgiam em torno da preservação do Bioma Mata Atlântica.

A década de 1980 é marcada pela incidência de e políticas ambientais, principalmente as políticas com orientação de comando e controle, marcando um novo estágio de conflitos na região. Por um lado, se seguiam as relações de arbitrariedade entre o pode público, as elites locais e as comunidades mais vulneráveis. As reivindicações preservacionistas inibiam inclusive os movimentos sociais dos pequenos agricultores em torno do direito pela terra. Relembrando que a agenda da agricultura familiar ficou marginalizada na região durante praticamente as duas referidas décadas. Somente no final da década de 1990 que há uma guinada em torno dos movimentos sociais. As ONGs adotaram o discurso conservacionista, e houve uma aproximação destas com os movimentos sociais e comunidades tradicionais. Percebemos também o surgimento de organizações de agricultores familiares já dentro da perspectiva propositiva de ações, em detrimento da antiga posição reativa frente às ações estatais.

A mobilização social que surgiu no Território Vale do Ribeira durante essas décadas foi o principal vetor de mudanças nas dinâmicas sociais, ambientais e econômicas na região. E é neste ambiente de efervescência política que os programas de desenvolvimento territorial são implementados no Vale do Ribeira. Este momento ia de encontro a solidificação da 
agenda governamental que criaria as políticas territoriais A implementação do PRONAT, se deu sob as mesmas limitações debatidas durante este estudo (viés setorial, foco na agricultura familiar, projetos de pouco impacto, entre outros). Contudo, a elaboração do Projeto VRS foi considerado o maior e mais qualificado processo de mobilização em torno da elaboração de um projeto territorial. A equipe do IDESC atuou na mobilização em torno da capacitação e organização dos agentes locais, visando à implementação de pequenos projetos de fortalecimento do capital social, educação ambiental, e alternativas de geração de renda e conservação dos recursos naturais. O processo de elaboração do Projeto VRS foi determinante no fortalecimento e no surgimento de boa parte das principais organizações de agricultores familiares e mobilizadores do Vale do Ribeira e poderia ter sido um conjunto de diretrizes efetivas para alterar o quadro de desenvolvimento territorial.

No entanto, este processo ocorreu com ausência de compromisso formalizado do poder público local, em especial os prefeitos. A ausência das prefeituras impediu a consolidação do Plano VRS a nível regional. Em adição, a intermitência de participação dos órgãos públicos do governo estadual, em especial os órgãos da Secretaria de Agricultura e Abastecimento, e a ausência dos órgãos públicos da Secretaria do Meio Ambiente, impede que diversos temas ligados às estas entidades sejam solucionados.

Além disso, por mais que haja boa vontade e capacitação por parte das organizações sociais em transformar a realidade social, deixar o processo de elaboração de um planejamento territorial para estas organizações evidencia suas fragilidades quanto à capacidade de agir sobre todo o território, bem como a capacidade de mobilizar e criar compromissos com o poder público local.

Finalmente, temos a análise da implementação do Programa Territórios da Cidadania no Vale do Ribeira. A abordagem processual da política nos permitiu evidenciar que a implementação o programa ocorreu sob uma fase de desmobilização e saída do IDESC da coordenação do CONSAD. A maior parte do poder público local não aceitou o compromisso de participar efetivamente da execução do plano regional, bem como houve ausência da maior parte dos órgãos públicos do governo estadual durante a elaboração do plano.

Desta forma, a gestão do CONSAD foi repassada a assessora técnica de gestão social. Entretanto, a gestão do PTC era ausente de qualquer infraestrutura local, ou de composição de uma equipe. No decorrer da gestão do programa, surgiram problemas contratuais da assessora local, em muito pela CPI das ONGs e também pela morosidade do MDA em resolver os impedimentos contratuais com as ONGs e cooperativas que contratavam os técnicos territoriais, mesmo após a dissolução da CPI. A precarização e terceirização da contratação da 
assessoria territorial é um relevante impeditivo de lograr ações efetivas por parte dos assessores territoriais. As poucas reuniões que foram realizadas no CONSAD não conseguiram efetivar um plano territorial durante toda a gestão. Os encontros se resumiam ao debate do PROINF, e da reestruturação da diretoria e comissão executiva. Mas após o imbróglio causado pelo não registro da gestão Emilson Couras, o CONSAD fícou impossibilitado de funcionar regularmente.

Os impedimentos burocráticos que surgiram ao longo dos anos culminaram na decisão de fechamento do CONSAD, ocorrido em 2014. Agora, há mudanças estruturais no PTC, com a inclusão das universidades e núcleos de extensão rural como co-participantes da gestão territorial. Assim, identificamos que houve uma mudança tanto na execução das ações, como na composição normativa da agenda nacional do país. Houve um retrocesso quanto a utilização da abordagem territorial do desenvolvimento rural como norte orientador de formulação e implementação de políticas públicas, voltadas a moldagem de um ambiente institucional que valorize a construção do bem público, orientada à transformação nas relações sociais e econômicas, visando promover a transformação produtiva e revalorização simbólica e material dos territórios.

Com base nos elementos sintetizados acima, podemos retornar a pergunta elaborada no primeiro capítulo desta dissertação: Porque os arranjos institucionais voltados à promoção da abordagem territorial do desenvolvimento rural não foram efetivos no Vale do Ribeira?

Em vistas as análises elaboradas durante este relatório, As iniciativas em torno das políticas públicas de desenvolvimento territorial são comprometidas pelas descontinuidades entre ações políticas e pela ausência da estrutura institucional que seja compatível aos objetivos propostos pelos programas territoriais.

A hipótese construída pretendeu evidenciar os resultados das políticas públicas territoriais. Porém, em complementaridade a abordagem processual, concluímos também que as regras assimétricas reproduzidas historicamente na região compõem forças de resistência à criação de uma dinâmica transformadora no Território Vale do Ribeira.

Este foi um caso com poucos efeitos positivos, e este fato está ligado ao contexto brasileiro e na América Latina em grande medida, já que as ações territoriais com maior êxito têm como evidências mais próximas às contingências sociais e políticas que um determinado território moldou ao longo de sua história, e muito menos relacionado à intervenção propositiva e efetiva por parte do Estado, que, por efetuar um papel passivo quanto à função 
de indutor à melhoria de qualidade de vida dos mais vulneráveis, atua quase sempre mantendo ou reforçando as assimetrias sociais.

Porém, como tentamos demonstrar ao longo desta dissertação, há uma rica diversidade de estudos realizados em torno da abordagem territorial do desenvolvimento rural, reforçando a necessidade do retorno desta abordagem a agenda pública brasileira. A literatura evidencia como se pode obter uma riqueza de contextos com a análise das políticas públicas sob a ótica do DTR. Este movimento fortalece a agenda territorial como uma saída propositiva de construção do desenvolvimento inclusivo socialmente, com cooperação institucional e planejado segundo as premissas da sustentabilidade.

\section{RECOMENDAÇÕES DE PESQUISA}

A partir das observações de campo e dos limites que esta pesquisa atingiu, teceremos alguns comentários sobre alguns campos de estudos que consideramos necessários a uma melhor compreensão das ações estatais no Vale do Ribeira.

Percebemos a ausência de estudos voltados à compreensão dos alcances e limites das políticas de desenvolvimento regional promovidas pelo Estado. Como exemplos, podemos exemplificar as ações públicas como o Programa Estadual de Microbacias Hidrográficas (PEBH), o Programa Paulista da Agricultura de Interesse Social (PPAIS) e mais recentemente o Programa Minha Terra, que atuam diretamente na facilitação da comercialização dos produtos agrícolas, pelo incremento de maquinário ao agricultor e apoio a ações de regularização fundiária, respectivamente não são alvos de investigação. Em adição, também não há literatura que aborde a gestão das diversas políticas e verbas de repasse que as prefeituras são responsáveis. Pelo fato desta investigação ser recortada metodologicamente aos limites do CONSAD, acabamos por não nos aproximarmos dos tomadores de decisão á nível local devido à desmobilização do colegiado. Neste sentido, a ausência de representantes dos órgãos públicos municipais no CONSAD acaba por limitar uma aproximação do deste trabalho ao conjunto de gestores públicos municipais e prefeitos.

Como consequência da ausência de estudos direcionados as políticas públicas estaduais, os colegiados regionais não são o foco de atenção de pesquisa. Mencionamos aqui o Conselho de Bacias Hidrográficas Ribeira de Iguape e Litoral Sul (CBH-RB), responsável por toda a gestão dos recursos hídricos da região, e o Consórcio de Desenvolvimento Intermunicipal do Vale do Ribeira (CODIVAR). Ambos colegiados jogam um importante papel na região por possuírem fundos voltados a promoção de projetos de gestão e proteção 
dos recursos hídricos (Fundo Estadual de Recursos Hídricos - FEHIDRO) e de fomento ao desenvolvimento socioeconômico regional (Fundo de Desenvolvimento Econômico e Social do Vale do Ribeira - FVR), respectivamente (FRANÇA, 2005). Ademais, o CODIVAR é responsável pelo Consórcio Intermunicipal de Saúde do Vale do Ribeira (CONSAUDE), importante arranjo interinstitucional de gestão das instituições médicas e ambulatoriais do Vale (CRUZ et al, 2005). Outra política recentemente proposta é o Macrozoneamento do Vale do Ribeira proposto pela Secretaria do Meio Ambiente. Estes diversos recortes regionais também mostram um relevante campo de pesquisa, no sentido de compreender quais tipos de relações que eles promovem entre si.

Numa perspectiva das abordagens relacionais, há um campo de pesquisa latente na identificação das redes sociotécnicas (CALDAS; MOREIRA, 2013). A perspectiva das redes pode evidenciar qual é o papel dos técnicos, gestores, intelectuais e militantes quanto à formação de alianças e conflitos em torno da gestão pública.

A abordagem da construção social dos mercados (BEDUSCHI; ABRAMOVAY, 2004) é uma interessante lente de investigação, já que apesar de falarmos de uma região cujo maior porcentagem da renda provém de atividades direta ou indiretamente ligadas ao setor agropecuário, não há estudos que iluminem quem são estes atores categorizados pela literatura organizada nesta dissertação como "pequenos posseiros", "grandes bananicultores", "terceiros", "cooperativa", "associações", etc. A ausência de uma investigação criteriosa em torno de como estes grupos redunda numa generalização e má compreensão do real papel que estes atores empreendem no Vale do Ribeira.

No todo, há uma percepção geral que a agenda de pesquisa regional esta voltada em sua maior parte para a compreensão dos conflitos socioambientais, marca histórica da região. A partir desta constatação, resgatamos a afirmação de Ferreira (2004, p. 61):

\footnotetext{
“As vitórias políticas de movimentos sociais, grupos de pressão na Mata, apesar da importância para minimizar os impactos de políticas excludentes de conservação da biodiversidade sobre a vida social de pequenos agricultores familiares, pescadores e extratores de pequena escala, acabaram por ideologizar o debate acadêmico, diminuindo o impacto científico de pesquisas que de fato investigam as características do uso de recursos naturais por populações que habitam áreas biogeográficas caracterizadas pela alta biodiversidade ou os conflitos em torno desses usos."
}

Em que pese à relevância da compreensão dos conflitos socioambientais em torno da proteção da biodiversidade e da manutenção das comunidades locais, esta variável isolada não 
é suficiente para compreender diversos outros condicionantes de um sistema complexo como o Vale do Ribeira. 


\section{REFERÊNCIAS}

ABRAMOVAY, R.; MAGALHÃES, R.; SCHRODER, M. Representatividade e inovação na governança dos processos participativos: o caso das organizações brasileiras de agricultores familiares. Sociologias, Porto Alegre, ano 12, n. 24, p. 268-306, maio./ago. 2010.

. Para uma teoria de los estúdios territoriales. In: MANZANEL, M.; NEIMAN, G.; LATTUADA, M. (Comp.). Desarrollo rural: organzaciones, instituciones y territórios. $1^{\text {a }}$ ed. Buenos Aires: Fundación Centro Integral Comunicación, Cultura y Sociedad - CICCUS, p. 51-71, 2006.

. Desenvolvimento Rural Territorial e Capital Social. In: SABOURIN, E.; OLÍVIO, T. (Orgs.). Planejamento do desenvolvimento dos territórios rurais: Conceitos, controvérsias e experiências - Brasília: UFPB/CIRAD/EMBRAPA, p. 113-128, 2002.

. Funções e medidas da ruralidade no desenvolvimento contemporâneo. Brasília; Rio de Janeiro: IPEA/MPOG, 2000a, 31 p. Textos para Discussão n. 702.

O capital social dos territórios: repensando o desenvolvimento rural. Economia Aplicada, v. 4, n. 2, p. 379-397, 2000 b.

ABRAMOVAY, R.; VEIGA J. E. Novas instituições para o desenvolvimento rural: o caso do programa nacional de fortalecimento da agricultura familiar (PRONAF). Brasília; Rio de Janeiro: IPEA/MPOG, 2000, 31 p. Textos para Discussão n. 641.

ADAMS, C. et al, Diversifying Incomes and Losing Landscape Complexity in Quilombola Shifting Cultivation Communities of the Atlantic Rainforest (Brazil). Human Ecology, v. 41 issue 1, p. 119-137, feb. 2013.

Caiçaras na mata atlântica: pesquisa científica versus gestão ambiental. São Paulo: FAPESP/ANNABLUME, 2000. 337p.

ANDRADE, A. M. TATTO, N. Inventário cultural de Quilombolas do Vale do Ribeira: Abobral (margem Esquerda), Bombas, Canguma, Galvão, Ivaporunduva, Mandira, Maria Rosa, Morro Seco, Nhunguara, Pedro Cubas, Pedro Cubas de Cima, Pilões, Porto Velho, Praia Grande, São Pedro, Sapatu. São Paulo: ISA. 2013. 379p.

ALVES, M. M. A força do povo. $1^{\text {a }}$ ed. São Paulo: Brasiliense. 1980. 122p. 
BARBOSA, M. V. F. Implementação de políticas públicas com a perspectiva da ação intersetorial: uma análise comparada do programa travessia e do programa cultivar, nutrir e educar. 2014. 162p. Dissertação (Mestrado em Ciência Política) Faculdade de Filosofia e Ciências Humanas, Universidade Federal de Minas Gerais. 2014.

BEDUSCHI FILHO, L. C. Tendências e perspectivas dos Programas de Segurança Alimentar e Nutricional nos Territórios Rurais da América Latina. Revista faz ciência, v. 14, n. 20, jul./dez. 2012.

Participação e Aprendizagem Social em Processos de Desenvolvimento Territorial Rural: Evidências de Dois Estudos de Caso no Brasil. Revista Econômica do Nordeste, Fortaleza, v. 38, n. 2, p. 259-275, abr./jun. 2007.

BEDUSCHI FILHO L. C.; ABRAMOVAY, R. Desafios para o desenvolvimento das regiões rurais. Nova Economia, Belo Horizonte, v. 14, n. 3, p. 35-70, 2004.

BEDUSCHI FILHO, L. C.; ABRAMOVAY, R. Desafios para a gestão territorial do desenvolvimento sustentável no Brasil. In: CONGRESSO BRASILEIRO DE ECONOMIA E SOCIOLOGIA RURAL, 41. Juiz de Fora, SOBER, 2003.

BERDEGUÉ, J. A.; ESCOBAL, J.; BEBBINGTON, A. Explaining Spatial Diversity in Latin American Rural Development: Structures, Institutions, and Coalitions. World Development. 2014. Disponível em: <http://dx.doi.org/10.1016/j.worlddev.2014.10.01>. Acesso em: 10 jan. 2015.

BIM, O. Mosaico do Jacupiranga - Vale do Ribeira, São Paulo: conservação, conflitos, e soluções socioambientais. 2012, 267p. (Dissertação em Geografia Física) Faculdade de Filosofia, Letras e Ciências Humanas. 2012.

BONNAL, P.; KATO, K. Análise comparativa de políticas públicas de desenvolvimento territorial. In: MIRANDA, C.; TIBURCIO, B. Reflexões e proposições de políticas públicas de desenvolvimento territorial. Brasília: IICA, 2012. 185p. Série Desenvolvimento Rural Sustentável; v. 15.

BRAGA, R. Planejamento regional no estado de São Paulo: A experiência do Vale do Ribeira nas décadas de 197 e 1980. 1998. 226p. (Doutorado em Geografia Humana) Faculdade de Filosofia, Letras e Ciências Humanas. 1998

BRASIL. Decreto de 25 de fevereiro de 2008. Institui o Programa Territórios da Cidadania. Disponível em: 
$<$ http://www.planalto.gov.br/ccivil_03/_Ato2007-2010/2008/Dnn/Dnn11503.htm>. Acesso em: 18 jan. 2015.

BUAINAIN, A. M.; ROMEIRO, A. R.; GUANZIROLI, C. Agricultura Familiar e o Novo Mundo Rural. Sociologias, Porto Alegre, ano 5, n. 10 p. 312-347, jul./dez. 2003.

CALDAS, E. L. Formação de agendas governamentais locais: o caso dos consórcios intermunicipais. 2007. 227. Tese (Doutorado em Ciência Política) Faculdade de Filosofia, Letras e Ciências Humanas, Universidade de São Paulo, 2007.

CALDAS, E. L.; MOREIRA, I. Políticas de desenvolvimento territorial e intermunicipalidade no Brasil: complementaridades e tensões. Sustentabilidade em Debate, Brasília, v. 4, n. 2, p. 41-61, jul./dez. 2013.

CAPELlA, A. C. N. Perspectivas Teóricas sobre o Processo de Formulação de Políticas Públicas. Revista Brasileira de Informação Bibliográfica em Ciências Sociais, São Paulo, n. 41 , p. 25-53, 2006.

CARVALHO, A. Possibilidades e limites do Programa Territórios da Cidadania a partir da sua realização no Território Região Central e no Município de Santa Maria/RS. 2012, 258p. Dissertação (Mestrado em Geografia da Produção do Espaço e Dinâmica Regional), Centro de Ciências Naturais e Exatas, Universidade Federal de Santa Maria. 2012.

CARVALHO FILHO, I. E. Old-age benefits and retirement decisions of rural elderly in Brazil. Jornal of Development Economics, v. 86, n. 1, p. 129-146, 2008.

CARVALHO, M. L.; BARBOSA, T. R. C. G.; SOARES, J; B; Implementação de política pública: uma abordagem teórica e crítica. COLÓQUIO ITENERNACIONAL SOBRE GESTIÓN UNIVERSITARIA EM AMÉRICA DEL SUR, 10. Mar Del Plata, 2010.

CAZELLA, A. A. BONNAL, P. MALUF, R. S. Olhares disciplinares sobre territórios e desenvolvimento territorial. In: CAZELLA, A. A. BONNAL, P. MALUF, R. S. (Orgs.) Agricultura familiar: multifuncionalidade e desenvolvimento territorial no Brasil. Rio de Janeiro: Ed. MAUDAD. 2009. 301p.

CHABARIBERY, D. et al. Diagnóstico das Condições Socioeconômicas e Tipificação dos Municípios. In: ROMÃO, D. A. (Org.). Vale do Ribeira: um ensaio para o desenvolvimento das comunidades rurais. Brasília. MDA/NEAD, 2006. 212p. 
COELHO, V. S.; P FAVARETO, A. Dilemas da participação e desenvolvimento territorial. Revista de Desenvolvimento Econômico, Salvador, BA, ano 10, n. 18, dez. 2008.

COELHO, V. S. P.; FAVARETO, A.; GALVANESE, C.; MENINO, F. Fóruns Participativos e Desenvolvimento Territorial no Vale do Ribeira. (Brasil). SEMINÁRIO INTERNACIONAL "TERRITORIOS RURALES EM MOVIMIENTO : movimentos sociales, actores e instittucionales del desarrollo territorial rural. Santiago de Chile, 23 a 26 de abril de 2006.

COELHO, V. S. P. et al. As regras do jogo e o jogo das regras - movimentos sociais, governança ambiental e desenvolvimento territorial no Vale do Ribeira (Brasil). 2005. 36p. Disponível em:

$<$ https://www.academia.edu/4238214/As_regras_do_jogo_e_o_jogo_das_regras_movimentos_sociais_governan $\% \mathrm{C} 3 \% \mathrm{~A} 7 \mathrm{a}$ a ambiental_e_desenvolvimento_territorial_no_Va le_do_Ribeira_Brasil_1>.Acesso em: jun. 2013.

COElHO, V. S. P.; FAVARETO, A. (Coords.). Barragem do Tijuco Alto: emprego, recursos naturais e direitos das comunidades tradicionais em debate nos fóruns participativos do Vale do Ribeira. Centro Brasileiro de Análise e Planejamento - CEBRAP. Relatório de Pesquisa - Junho de 2005. 22 p.

COMISSÃO PRÓ -ÍNDIO DE SÃO PAULO - CPISP. Terras indígenas em São Paulo. Disponível em: <http://www.cpisp.org.br/indios/html/uf.aspx?ID=SP $>$. Acesso em: $10 \mathrm{dez}$ 2014.

COMISSÃO CAMPONESA DA VERDADE - CCV. Relatório final: violações no campo 1946 a 1964. Brasília: Dezembro de 2014. Disponível em: $<$ http://www.cnv.gov.br/index.php/2012-05-22-18-30-05/camponeses-e-indigenas $>$. Acesso em: 28 jan. 2015.

CUSTÓDIO, M. B. Política nacional de segurança alimentar e nutricional no Brasil: arranjo institucional e alocação de recursos. 2009. 326 f. Tese (Doutorado) Faculdade de Economia, Administração e Contabilidade da USP. Faculdade de Saúde Pública da USP. Curso Interunidades em Nutrição Humana Aplicada. 2009.

CRUZ, et al. Consórcios intermunicipais de desenvolvimento: mudando para sobreviver. CONGRESSO CONSAD DE GESTÃO PÚBLICA, 2 - Painel 36: Consórcios intermunicipais como arranjos de cooperação 2005.

DEAN, W. A ferro e fogo: a história e a devastação da mata atlântica brasileira. São Paulo: Companhia das Letras. 1996. 484p. 
DUARTE, A. A crise do fordismo nos países centrais e no Brasil. Trabalho \& Educação, Belo Horizonte, n.7, jul./dez. 2000.

DURSTON, J. \& Qué es el capital social comunitario?. Santiago de Chile, ONU/CEPAL/ECAC, 2000. 44p.

ECHEVERRI, R. Emergência e evolução do Programa de Desenvolvimento Sustentável dos Territórios Rurais e nos Territórios da Cidadania. In: FAVARETO, A. et al. Políticas de desenvolvimento territorial rural no Brasil: avanços e desafios. Brasília: IICA, 2010. 220p.

ESTANQUE, ELÍSIO. Análise das classes e desigualdades sociais em Portugual: em defesa da perspectiva compreensiva. CES - Centro de Estudos Sociais. Universidade de Coimbra: Oficina do CES, n. 121, fev. 2005.

FAVARETO, A. abordagem territorial do desenvolvimento rural - mudança institucional ou “inovação por adição"? Estudos Avançados, v. 24, n. 68, p. 299-219, 2010a.

. As políticas de desenvolvimento territorial rural no Brasil em perspectiva: uma década de experimentações. Desenvolvimento em Debate, v. 1 n. 2 p. 47-63, jan./abr. mai./ago., 2010b.

. Retrato das políticas de desenvolvimento territorial no Brasil. Santiago do Chile: Centro Latinoamericano para el Desarrollo Rural - Rimisp. 2009, 86p. Documento de Trabajo n. 26. 2009.

. Paradigmas do Desenvolvimento rural em questão : do agrário ao territorial. 2006. 220 f. Tese (Doutorado em Ciência Ambiental) - Instituto de Energia e Ambiente, Universidade de São Paulo, São Paulo, 2006a.

Agricultores, trabalhadores: os trinta anos do novo sindicalismo rural no Brasil.

Revista Brasileira de Ciências Sociais, v. 21, n. 62, out. 2006 b.

A racionalização da vida rural. Estudos Sociedade e Agricultura, Rio de Janeiro, v. 14, n. 1, p. 9-48, $2006 \mathrm{c}$.

FAVARETO, A. et al, A dimensão territorial do desenvolvimento brasileiro recente Brasil (2000-2010). São Paulo; Chile, Rimisp/Cebrap/UFABC, fev. 2014.

FERNANDES, B. M.; WELCH, C. A. GONÇALVES, E. C. Debates sobre políticas fundiárias e usos da terra no Brasil. Uma análise geo-histórica da governança da terra no 
Brasil. International Land Coalition. 2012. Disponível em: $<$ http://www.landcoalition.org/sites/default/files/publication/1372/FramingtheDebateBrazil_P ortuguese.pdf $>$. Acesso em 21 jul. 2014

FERREIRA, L. C. Dimensões humanas da biodiversidade: mudanças sociais e conflitos em torno de áreas protegidas no Vale do Ribeira, SP, Brasil. Ambiente \& Sociedade, v. 7, n. 1 jan. 2004.

FRANÇA, A. M. Vale do Ribeira (SP): Proposições econômicas, sociais, políticas e ambientais para o crescimento e desenvolvimento sustentável dos municípios da região administrativa de Registro. 2005. 323f. Dissertação (Mestrado em Economia Política) Pontifícia Universidade Católica de São Paulo, PUC-SP. 2005.

FREITAS, A. F.; DIAS, M. M.; FREITAS, A. F. O programa Nacional de Desenvolvimento Sustentável de Territórios Rurais: a indução de territorialidades à ação pública. Perspectivas em Políticas Públicas, Belo Horizonte, v. 3, n. 6, p. 27-58, jul./dez. 2010.

FREIRE, P. Extensão ou comunicação? Rio de Janeiro: Paz e Terra, 1983.

FREY, K. Políticas públicas: um debate conceitual e reflexões referentes à prática da análise de políticas públicas no Brasil. Planejamento e Políticas Públicas, Brasília, n. 21, p. 212259 , jun. 2000.

FUNDAÇÃO SISTEMA ESTADUAL DE ANÁLISE DE DADOS . Disponível em : http://www.seade.gov.br. Acesso em: 10 ago. 2010.

FUTEMMA, C. R. T. et al. The Afro-Brazilian collective land: analyzing institutional changes in the past 200 years. Latin American Research Review, n. 1, 2014. (no prelo)

GALVANESE, C. S. Dilemas do planejamento e as instituições do desenvolvimento sustentável: estudo sobre as barragens e a questão regional do Vale do Ribeira. 2009. $178 \mathrm{f}$. Dissertação (Mestrado em Energia) Programa de Pós Graduação em Energia. Universidade Federal do ABC. 2009.

GOHN, M. G. Conselhos e gestão pública. Ciências Sociais Unisinos, v. 42, n. 1, jan./abr. 2006.

GRAZIANO DA SILVA, J; GÓMES, S.; CASTAÑEDA, R. "Boom” Agrícola e persistência da pobreza na América Latina: algumas reflexões. Revista NERA, Presidente Prudente, SP, ano. 3, n. 16, p. 07-21, jan./jun. 2010. 
GRAZIANO DA SILVA, J.; GROSSI, M. D. CAMPANHOLA, C. El nuevo rural brasileño. Alarsu : associación Latinoametical Del medio rural, México, v. 1, p. 47-68, 2005.

GROSTEIN, M. D. Metrópole e expansão urbana: a persistência de processos “insustentáveis". São Paulo em Perspectiva, v. 15, n. 1, p. 13-19, 2001.

GUANZIROLI, C. E. PRONAF dez anos depois: resultados e perspectivas para o desenvolvimento rural. RER, Rio de Janeiro, v. 45, n. 2, p. 301-328, abr.jun. 2007.

GUIMARÃES, M. D. A. Desenvolvimento rural: territórios e redes. 2013. 262 f. Tese (Doutorado em Ciências Sociais) - Coordenação do Programa de Pós-Graduação de Ciências Sociais em Desenvolvimento, Agricultura e Sociedade, Universidade Federal Rural do Rio de Janeiro, Rio de Janeiro 2013.

HESPANHOL, R. A. M. A adoção da perspectiva territorial nas políticas públicas de desenvolvimento rural no Brasil. CAMPO-TERRITÓRIO: REVISTA DE GEOGRAFIA AGRÁRIA, v. 5, n. 10, p.123-147, ago. 2010.

HILL, M. Implementação: Uma visão geral. In: SARAIVA H.; FERRAREZI, E. (Orgs.). Políticas públicas: Coletânea - v. 1. Brasília: ENAP. 2006. p. 61-90.

INSTITUTO BRASILEIRO DE ADMINISTRAÇÃO MUNICIPAL- IBAM. Guia do CONSAD: Consórcio de Segurança Alimentar e Desenvolvimento Local. 2004. 51p. Disponível em: <http://www.mds.gov.br/backup/teste/seguranca-alimentar-e-nutricionalsan/consad/guiaconsadrev3.pdf>. Acesso em: 14 out. 2014.

INSTITUTO PARA O DESENVOLVIMENTO SUSTENTÁVEL E CIDADANIA NO VALE DO RIBEIRA - IDESC. Projeto Vale do Ribeira Sustentável: Relatório Anual de Atividades. Janeiro a Dezembro de 2007. 63p. Disponível em $<$ http://www.idesc.org.br/relatorio.asp>. Acesso em: 15 nov. 2014.

Projeto Vale do Ribeira Sustentável: Relatório Anual de Atividades. Janeiro a Dezembro de 2006a. 78p. Disponível em <http://www.idesc.org.br/relatorio.asp > . Acesso em: 15 nov. 2014.

. Plano de Desenvolvimento Territorial Sustentável do Vale do Ribeira. Vale do Ribeira, 2006b. 63p. Disponível em:

$<$ http://www.idesc.org.br/arquivos/docs/PLANO\%20DE\%20DESENVOLVIMENTO\%20TE RRITORIAL\%20DO\%20PROJETO\%20VALE\%20DO\%20RIBEIRA\%20SUSTENTAVELFINAL.pdf $>$.

Acesso em: 15 nov. 2014. 
INSTITUTO PARA O DESENVOLVIMENTO SUSTENTÁVEL E CIDADANIA NO VALE DO RIBEIRA - IDESC . Elaboração do plano de desenvolvimento territorial sustentável do Vale do Ribeira e implantação de projetos socioambientais prioritários. Registo, 2005a. 52 p. Disponível em:

$<$ http://www.idesc.org.br/arquivos/docs/ResumoProjeto.pdf $>$. Acesso em: 15 jan. 2015.

Projeto Vale do Ribeira sustentável: Relatório das atividades janeiro a dezembro de 2005. 2005b. 97 p. Disponível em <http://www.idesc.org.br/relatorio.asp>. Acesso em: 15 nov. 2014.

. Síntese do Projeto: Elaboração do plano de desenvolvimento territorial sustentável do Vale do Ribeira e implantação de projetos socioambientais prioritários. 2004. 9p. Disponível em <http://www.idesc.org.br/relatorio.asp>. Acesso em: 15 nov. 2014.

INSTITUTO PARANAENSE DE DESENVOLVIMENTO ECONOMICO E SOCIAL IPARDES. Disponível em: <http://www.ipardes.pr.gov.br/>. Acesso em: 11 nov. 2014.

ITESP - FUNDAÇÃO INSTITUTO DE TERRAS DO ESTADO DE SÃO PAULO. Terra e cidadãos: Aspectos da Ação de Regularização Fundiária no Estado de São Paulo. São Paulo: ITESP. 2000. 142p.

KARAM, R. A. S. A economia política do desenvolvimento territorial: uma análise da diversidade institucional na agenda brasileira. 2012. 282p. Tese (Doutorado em Políticas Públicas, Estratégias e Desenvolvimento). Instituto de Economia, Universidade Federal do Rio de Janeiro, 2012.

KINGDON, J. Juntando as coisas. In: SARAIVA, E. FARRAREZI, E. (Orgs.) Políticas públicas: Coletânea - v. 1. Brasília: ENAP. 2006. 313p.

KRONEMBERGER, T. S.; VILLELA, E. L.; ZANI, F. B. APLs e Desenvolvimento Territorial: um Estudo sobre o Programa Território da Cidadania Norte do Rio de Janeiro. In: ENCONTRO NACIONAL DE PESQUISADORES EM GESTÃO SOCIAL, 6., 2012, São Paulo. Anais. ENAPEGS, 2012.

LEITE, S. P.; WESZ Jr. Um estudo sobre o financiamento da política de desenvolvimento territorial no meio rural brasileiro. Piracicaba-SP, v. 50, n. 4, p. 645-666, out./dez. 2012.

LIMA, L. L.; D’ASCENZI, L. Implementação de políticas públicas: perspectivas analíticas. Revista de Sociologia e Política, v. 21, n. 48, p. 101-110, dez. 2013. 
LIMA, R. V. A. Modelagem baseada em agentes para avaliar a sustentabilidade da exploração do palmito jussara por comunidades quilombolas do Vale do Ribeira, São Paulo. 2013. 122p. Dissertação (Mestrado em Modelagem de Sistemas Complexos) Escola de Artes, Ciências e Humanidades, Universidade de São Paulo, 2013.

LOPES, J. F. R. Território e participação política: o colegiado Norte Fluminense. 2012. 120 p. Dissertação (Mestrado em Administração Pública), Escola Brasileira de Administração Pública e de Empresas, Fundação Getúlio Vargas, 2012.

LOTTA, G.; FAVARETO, A. O papel dos territórios nos novos arranjos institucionais brasileiros. CONGRESSO DO CENTRO LATINOAMERICANO DE ADMINISTRAÇÃO PARA O DESENVOLVIMENTO SOBRE A REFORMA DO ESTADO E DA ADMINISTRAÇÃO PÚBLICA, 18 ., 2013, Montevideo. Anais. 2013.

LORETO, M. D. S.; SANTOS, C. L.; GOMES, A. L. A formação e gestão do Território Rural da Serra do Brigadeiro-MG: a percepção dos conselheiros. ENCONTRO NACIONAL DE GEOGRAFIA AGRÁRIA, 21., 2012, Uberlândia. Anais. 2012.

MARQUES, P. E. M. Críticas e justificações em torno de alternativas agrícolas no Estado de São Paulo. 2013. 163 f. (Livre Docência) Escola Superior de Agricultura "Luiz de Queiróz", 2013.

MAZOYER, M.; ROUDART, L. História das agriculturas no mundo: do neolítico à crise contemporânea. São Paulo: Unesp: Brasília, DF: NEAD. 2010. 568p.

MEYERS, M; K; VORSANGER, S. Burocratas de nível de rua e a implementação de políticas públicas. In: PETERS G.; PIERRE, J. (Orgs.). Administração Pública: coletânea. Tradução Sonia Midori Yamamoto, Mirian Oliveira. São Paulo: UNESP; Brasília, DF: ENAP, 2010. p. 249-270.

MINISTÉRIO DO DESENVOLVIMENTO AGRÁRIO - MDA. Sistemas de Informações Territoriais. Disponível em: $<\mathrm{http}: / /$ sit.mda.gov.br/territorio.php? $\mathrm{menu}=$ cidadania\&base=2>. Acesso em: 10 jan. 2015.

. Plano Territorial de Desenvolvimento Rural Sustentável - Território Vale do Ribeira (SP). Plural Cooperativa, 2011. 55p.

Referências para o desenvolvimento territorial sustentável. Brasília: IICA/CONDRAF/NEAD, 2003. 
MINISTÉRIO DO MEIO AMBIENTE - MMA. Termo de Referência FNMA n0 03/2004. Elaboração e apoio à implementação do Plano de Desenvolvimento Territorial do Vale do Ribeira.

MONTENEGRO GÓMEZ J. R.; FAVARO, J. L. Uma Leitura Crítica do Desenvolvimento Territorial Rural Realmente Existente: entre as condições de possibilidade e a implantação. Revista Paranaense de Desenvolvimento, Curitiba, n. 122, p. 39-69, jan./jun. 2012.

MUNARI, L. C. Memória Social e Ecologia Histórica: a agricultura de coivara das populações quilombolas do Vale do Ribeira e sua relação com a formação da Mata Atlântica local. 2009. 217p. Dissertação (Mestrado em Ecologia) Instituto de Biociências, Universidade de São Paulo. 2009.

NAREZI, G. A agroecologia como estratégia de gestão de unidades de conservação de uso sustentável no Vale do Ribeira - SP, Brasil. 2012. $323 \mathrm{f}$. Tese (Doutorado em Ecologia Aplicada) Escola Superior de Agricultura "Luiz de Queiroz", Universidade de São Paulo, 2012.

NORTH, D. C. Institutions, institutional change and economic performance. Cambridge: Cambridge University Press, 1990. 152p.

OLIVEIRA, L. C. Gestão social no Território da cidadania Sertão de Minas: A perspectiva dos agentes públicos. 2012. 131f. Dissertação (Mestrado em Administração) Universidade Federal de Lavras, 2012.

OLIVEIRA, O. F. Territórios e cidadania em Rondônia: estudo das políticas de desenvolvimento rural sustentável nos Territórios Central e Madeira Mamoré. 2012. $209 \mathrm{f}$. Tese (Doutorado em Desenvolvimento Regional) Programa de Pós-Graduação em Desenvolvimento Regional, Universidade de Santa Cruz do Sul - UNISC, 2012.

OLIVEIRA, M. R. M. VIEIRA, C. M. GALESI, L. F. Relatório de atividades 2011-2012. Rede de Defesa e Promoção da Alimentação Saudável, Adequada e Solidária - REDE SANS. Disponível em: <http://www.redesans.com.br/o-projeto/>. Acesso em: 20 nov. 2014. 2012. $64 \mathrm{p}$.

ORTEGA, A O. Desenvolvimento Territorial Rural: os arranjos induzidos por políticas públicas e sua capacidade na promoção do desenvolvimento. CAMPO-TERRITÓRIO: Revista de Geografia Agrária. Ed. Espe. XXI ENGA-2012, p. 1-23, jun. 2014.

Desarrollo territorial rural y estructuras de gobernanza em Brasil. Economia, Sociedad y Territorio, v. 12, n. 38, p. 149-179, jan./abr. 2012. 
PACHECO, A. S. V. A participação cidadã nos territórios da cidadania: um estudo de caso no território do Meio Oeste do Contestado, à luz da gestão social. 2013, 179 f. Dissertação (Mestrado em Administração) Universidade Federal de Santa Catarina. 2013.

PANZUTTI, N. P. M.; CHABARIBERY, D.; MONTEIRO, A. V. V. M.; PETTIR, H. V. Organização sociopolítica em área de preservação ambiental. Cadernos Ceru, v. 24, n. 1, p. 49-64, nov. 2013.

PENNA-FIRME, R. BRONDÍZIO, E. The risks of commodifying poverty: rural communities, quilombola identity, and nature conservation in Brazil. Habitus, Goiana, v. 5, n. 2, p. 355-373, jul./dez. 2007.

PETRONE, P. A Baixada do Ribeira: Estudo de Geografia Humana. 1966. 432p

PIRES, M. J. S.; RAMOS, P. O Termo Modernização Conservadora: Sua Origem e Utilização no Brasil. Revista Econômica do Nordeste, v. 40, n. 3, jul./set. 2009.

PRADO, D. D. V. Consórcios públicos: análise do instrumento sob a perspectiva da ação orçamentária consad, executada pela secretaria nacional de segurança alimentar e nutricional (sesan) do ministério do desenvolvimento social e combate à fome (MDS). 2011. 127p. Dissertação (Mestrado em Saúde Pública) Escola Nacional de Saúde Pública, Fundação Osvaldo Cruz/IPEA, 2011.

PUTNAM, R. D. Comunidades e democracia: a experiência da Itália moderna. Rio de Janeiro: Fundação Getúlio Vargas, 1996. 260p.

QUEIRÓZ, R. S. Caipiras negros no Vale do Ribeira: um estudo de antropologia econômica. São Paulo: EDUSP. 2006. 136p.

RABINOVIC, A. Formatando roteiros turísticos quilombolas no entorno de Áreas Protegidas no Vale do Ribeira (SP). Revista Brasileira de Ecoturismo, São Paulo, v.5 n.2, pp. 153-172, mai./ago. 2012.

RAIMBERT, C. Rural Adaptation and Quilombola Community: Dynamics and Complexities of Nested Social Territorial Systems. CONFERENCE - CLIMATE VULNERABILITY AND ADAPTATION: MARGINAL PEOPLES AND ENVIRONMENTS, 2., Michigan, 2011. Proceedings. ICARUS II The School of Natural Resources and the Environment, Michigan, 2011. 
RAMBO, L. et al. Apreendendo dinâmicas territoriais de desenvolvimento por meio da análise escalar: um estudo do PROINF e das emendas parlamentares no Território Rural Zona Sul do Rio Grande do Sul. ACTA Geográfica, Boa Vista, Ed. Esp. Geografia Agrária. P. 103-132.

REDDING, S. J. Economic Geography: a review of the theoretical and empirical literature. Journal of Regional Science, v. 50, issue. 1. p. 297-311, feb. 2010.

RESENDE, R. U. As regras do jogo: legislação florestal e desenvolvimento sustentável no Vale do Ribeira. São Paulo: Annablume, 2002. 198p.

RIBEIRO, A. C. Coprodução, habilidades sociais e estratégias para o desenvolvimento rural: um estudo de caso do planejamento participativo no Território da Serra Catarinense. 2012. 228 f. Dissertação (Mestrado em Administração) Centro de Ciências da Administração e Socioeconômicas (ESAG), Universidade do Estado de Santa Catarina, 2012.

ROCHA, A. G. P. Políticas públicas e participação: os atores sociais na política de Desenvolvimento Territorial do Estado da Bahia. 2010. 211 f. Tese (Doutorado em Desenvolvimento Rural) Universidade Federal do Rio Grande do Sul. 2010.

ROCHA, P. E. D. Trajetórias e perspectivas da interdisciplinaridade ambiental na pósgraduação brasileira. Ambiente e Sociedade, v. 6, n. 2, jul./dez. 2003.

SÁ-SILVA, J. R.; ALMEIDA, C. D.; GUINDANI, J. F. Pesquisa documental: pistas teóricas e metodológicas. Revista Brasileira de História \& Ciências Sociais, ano 1, n. 1, jul. 2009.

SABOURIN, E. Que política pública para a agricultura familiar no segundo governo Lula? Sociedade e Estado, Brasília, v. 22, n. 3, p. 715-751, set./dez. 2007.

SACCO DOS ANJOS, F. BECKER, C. Agricultura familiar e mercados institucionais: o desenvolvimento como liberdade. Revista de Economia do Nordeste, v. 45, supl. esp. p. 107-117, out./dez. 2014.

SACCO DOS ANJOS, F. CALDAS, N. V. A propósito do debate sobre pluriatividade e multifuncionalidade na agricultura: o surgimento de uma nova forma discursiva. Revista THEOMAI: Estudios sobre Sociedad y Desarrollo, n. 20, 2009.

SACHS, I. O jogo da harmonização. In VIEIRA, P. F. (Org.). Rumo à Ecossocioeconômia: Teoria e prática do desenvolvimento. São Paulo: Cortez, 2007. 472p. 
SANTOS K. M. P. TATTO, N. (Ed.) Agenda Socioambiental de comunidades quilombolas do Vale do Ribeira - Instituto Socioambiental, 2008, 193p.

SÃO PAULO. SECRETARIA DE PLANEJAMENTO E DESENVOLVIMENTO REGIONAL. Caracterização Socioeconômica de São Paulo - Região Administrativa de Registro. Disponível em:

$<$ http://www.planejamento.sp.gov.br/noti_anexo/files/uam/trabalhos/Registro.pdf $>$. Acesso em: 27 nov. 2014.

SARAIVA, E. Introdução à teoria da política pública. . In: SARAIVA, E. FARRAREZI, E. (Orgs.). Políticas públicas: Coletânea - v. 1. Brasília: ENAP. 2006. 313p.

SCHEJTMAN, A.; BERDEGUÉ, J. A. Desarrollo territorial rural. Santiago de Chile: Centro Latinoamericano para el Desarrollo Rural - RIMISP. Debates y Temas Rurales, n. 1. 2004.

SCHERL, L. M. et al. 2006. As áreas protegidas podem contribuir para a redução da pobreza? Oportunidades e limitações. Gland: União Mundial para a Conservação da Natureza (IUCN).

SCHNEIDER, S. Situando o desenvolvimento rural no Brasil: o contexto e as questões em debate. Revista de Economia Política, v. 30, n. 3, p. 511-531, jul./set. 2010.

- Ciências Sociais, Ruralidade e Territórios: em busca de novas referências para pensar o desenvolvimento. Campo Território: revista de geografia agrária, v. 4, n. 7, p. 24-62, fev. 2009.

Teoria social, agricultura familiar e pluriatividade. Revista Brasileira de Ciências Sociais, v. 18, n. 51, fev. 2003.

SCHNEIDER, S.; MATTEI, L.; CAZELLA, A. A. Histórico, caracterização e dinâmica recente do PRONAF - Programa Nacional de Fortalecimento da Agricultura Familiar. In: SCHNEIDER, S.; SILVA, M. K.; MARQUES, P. E. M. (Org.). Políticas públicas e Participação Social no Brasil Rural. Porto Alegre: UFRGS, 2004, p. 21-50.

SILVA JÚNIOR, J. A. Sociedade, Sustentabilidade e Políticas Públicas no Vale do Ribeira: uma revisão. In: SIMPÓSIO INTERDISCIPLINAR DE CIÊNCIA AMBIENTAL, 2013, São Paulo. Anais. São Paulo: Instituto de Energia e Ambiente/USP, v.1, 2013.

SOUZA, C. Políticas Públicas: uma revisão da literatura. Sociologias, Porto Alegre, ano 8, n. 16, p. 20-45, jul./dez. 2006. 
SOUZA, C. Federalismo, desenho constitucional e instituições federativas no Brasil pós1988. Revista de Sociologia e Política, Curitiba, v. 24, p. 105-121, jun. 2005.

SOUZA, N. J. Economia Regional: conceitos e fundamentos teóricos. Perspectiva Econômica, São Leopoldo, ano 16, v. 11, n. 32, p. 67-102, 1981.

TANURE, T. M. P. Desenvolvimento territorial rural: políticas públicas no Território da cidadania do Noroeste de Minas Gerais. 2012. 138 f. Dissertação (Mestrado em Economia), Universidade Federal de Uberlândia. 2012.

TENÓRIO, F. G. (Re)Visitando o Conceito de Gestão Social. Desenvolvimento em Questão, ano 3, n. 5, p. 101-124, jan./jul. 2005.

TODESCO, C. Estado e terceiro setor na organização do espaço para o turismo no Vale do Ribeira. 2007. 207f. (Dissertação em Geografia Humana)- Faculdade de Filosofia, Letras e Ciências Humanas, 2007.

TRIBUNAL SUPERIOR ELEITORAL. Eleições anteriores. Disponível em: $<$ http://www.tse.jus.br/eleicoes/eleicoes-anteriores/eleicoes-anteriores $>$. Acesso em: 20 jan. 2015.

VALENTIN, A. Uma civilização do arroz: Agricultura, comércio e subsistência no Vale do Ribeira (1800-1880). 2006. 405 f. (Doutorado em História Econômica)- Faculdade de Filosofia, Letras e Ciências Humanas. 2006.

VEIGA, J. E. O Brasil rural ainda não encontrou seu eixo de desenvolvimento. Estudos Avançados, v. 15, n. 43, p. 101-119, 2001.

Pobreza Rural, Distribuição da Riqueza e Crescimento: a experiência brasileira. In: TEÓFILO, E et al. (Org.). Distribuição de Riqueza e Crescimento Econômico. Brasília: NEAD/CNDRS, 2000. p. 173-200.

VEIGA, J. E.; EHLERS, E. Diversidade biológica e dinamismo econômico no meio rural. In: MAY, P. (Org.) Economia do meio ambiente: teórica e prática. $8^{\mathrm{a}}$ ed. Rio de Janeiro: Elsevier/Campus. 2009, p. 289-308.

WINTER, S. C. Perspectivas de implementação: status e reconsideração. In: PETERS G.; PIERRE, J. (Orgs.). Administração Pública: coletânea. Tradução Sonia Midori Yamamoto, Mirian Oliveira. São Paulo: UNESP; Brasília, DF: ENAP, 2010. p. 209-227. 
ZANI, F. B.; TENÓRIO, F. G. Gestão Social do Desenvolvimento: o Desafio da Articulação de Atores Sociais no Programa Territórios da Cidadania Norte-RJ. In: ENCONTRO DE ADMINISTRAÇÃO PÚBLICA E GOVERNO - EnAPG/ANPAD. Salvador, BA, 2012.

ZIMMERMANN, S. A. et al. Desenvolvimento Territorial e Políticas de enfrentamento da pobreza rural no Brasil. CAMPO-TERRITÓRIO: Revista de Geografia Agrária, v. 9, n. 17, p. 540-573, abr. 2014. 


\section{APÊNDICE A - Atividades realizadas no Território Vale do Ribeira}

\section{Entrevistas}

BIM, Ocimar. Entrevista Realizada por Joaquim Júnior, em 17 de outubro de 2013, em Registro/SP.

CAPOBIANCO, João Paulo Ribeiro. Entrevista concedida a Revista Eletrônica Bioclimático. Disponível em:

$<$ http://ww.bioclimatico.com.br/pdf/entrevistas/SOS_\%20Capobianco_OK.pdf $>$. Acesso em: dez. 2014.

CARLOS, Antônio. Entrevista realizada por Joaquim Júnior, em 16 de abril de 2014, em Eldorado/SP

CARLOS, Antônio. Entrevista disponível em: BRANDÃO, C. R. TSIKIOKA, C. G. CARVALHO, M. C. P. O Cerco do Verde: o olhar dos outros sobre a questão do ambiente. Ambiente e Sociedade, Ano II, n.5, $2^{0}$ semestre, 1999.

FILHO, José Justino Desidério (Zezinho). Entrevista realizada por Joaquim Júnior, em 14 de abril de 2014, em Registro/SP.

. Entrevista realizada por Joaquim Júnior, em 26 de novembro de 2013, em Pariquera-Açu/SP.

HAYAMA, Andrew Toshio. Entrevista realizada por Joaquim Júnior, em 18 de outubro de 2013, em Registro/SP.

MAIA, Nivaldo Aparecido. Entrevista realizada por Joaquim Júnior, em 09 de novembro de 2013, em São Paulo/SP.

OLIVEIRA, Osvaldo Roberto (Beto). Entrevista Realizada por Joaquim Júnior, em 25 de novembro de 2013, em Eldorado/SP.

RESENDE, Roberto, Entrevista realizada por Joaquim Júnior, em 26 de setembro de 2013, em São Paulo/SP.

SILVA, Tania Maria. [vídeo conferência] Entrevista Realizada por Joaquim Júnior, em 16 de janeiro de 2015. Em São Paulo/SP. 
. Entrevista Realizada por Joaquim Júnior, em 16 de abril de 2014, em Registro/SP

Registro/SP.

. Entrevista realizada por Joaquim Júnior, em 17 de outubro de 2013, em

SODRZEIESKI, Antônio Eduardo (Mamute). Entrevista Realizada por Joaquim Júnior, em 13 de novembro de 2013, em Registro/SP.

SUELI, Irmã. Entrevista disponível em: BRANDÃO, C. R. TSIKIOKA, C. G. CARVALHO, M. C. P. O Cerco do Verde: o olhar dos outros sobre a questão do ambiente. Ambiente e Sociedade, Ano II, n.5 $2^{0}$ semestre, 1999.

YAMANE, Yassuo. Entrevista realizada por Joaquim Júnior, em 25 de novembro de 2013, em Eldorado/SP.

\section{Participação em eventos}

Seminário "Roças Quilombolas: Alimento, Cultura e Biodiversidade". Realizado em 17 de agosto de 2012, em Eldorado/SP.

"V Feira de Troca de Sementes e Mudas Tradicionais das Comunidades Quilombolas do Vale do Ribeira". Realizado em 18 de outubro de 2012, em Eldorado/SP.

Seminário “Oportunidades e desafios para o Vale do Ribeira: Pagamentos por Serviços Ambientais e Planos Municipais da Mata Atlântica". Evento Realizado entre os dias 29 e 31 de outubro de 2012, em Registro/SP.

Seminário "Sementes: soberania alimentar, cultura e geração de renda", realizada em 23 de agosto de 2013, em Eldorado/SP.

"IIV Feira de Troca de Sementes e Mudas Tradicionais dos Quilombos do Vale do Ribeira e V Feira Estadual de Troca de Sementes". Realizada em 24 de agosto de 2013, em Eldorado/SP.

Seminário "Cadastro Ambiental Rural, Mecanismos de Compensação de Reserva Legal e o Pagamento de Serviços Socioambientais no Vale do Ribeira". Evento Realizado entre os dias 07 e 08 de outubro de 2013, em Ivaporunduva, Eldorado/SP. 
Lançamento do "Programa Mais médicos". Evento realizado em 26 de novembro de 2013, em Pariquera-Açu/SP.

III Conferência Regional de Economia Solidária do Vale do Ribeira. Realizada em 15 de abril de 2014, em Registro/SP.

\section{Participação em reuniões}

Reunião de formação da Cooperativa dos Agricultores Quilombolas do Vale do Ribeira COOPERQUIVALE, em 28 de agosto de 2012, em Eldorado/SP.

Reunião de formação da Cooperativa dos Agricultores Quilombolas do Vale do Ribeira COOPERQUIVALE, em 11 de setembro de 2012, em Eldorado/SP.

Reunião de formação da Cooperativa dos Agricultores Quilombolas do Vale do Ribeira COOPERQUIVALE, em 18 de setembro de 2012, em Eldorado/SP.

Reunião de formação da Cooperativa dos Agricultores Quilombolas do Vale do Ribeira COOPERQUIVALE, em 03 de outubro de 2012, em Eldorado/SP.

Reunião de formação da Cooperativa dos Agricultores Quilombolas do Vale do Ribeira COOPERQUIVALE, em 25 de outubro de 2012, em Eldorado/SP.

Reunião de formação da Cooperativa dos Agricultores Quilombolas do Vale do Ribeira COOPERQUIVALE, em 23 de novembro de 2012, em Eldorado/SP.

Reunião ordinária da Associação Consórcio de Segurança Alimentar e Desenvolvimento Local do Vale do Ribeira CONSAD-VR, em 29 de outubro de 2013, em Registro/SP.

Reunião ordinária da Associação Consórcio de Segurança Alimentar e Desenvolvimento Local do Vale do Ribeira CONSAD-VR, em 27 de novembro de 2013, em Pariquera-Açu/SP.

Reunião sobre a importância da banana do Brasil, promovido pela Associação dos Bananicultores do Vale do Ribeira - ABAVAR, em 11 de abril de 2014, em Eldorado/SP. 